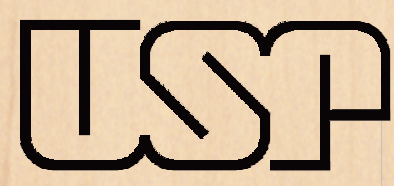

Universidade de São Paulo

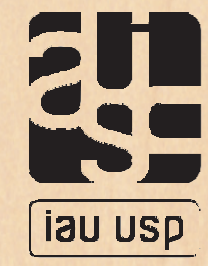

UNIVERSIDADE DE SÃO PAULO

INSTITUTO DE ARQUITETURA E URBANISMO DE SÃO CARLOS IAUSC/USP

JOÃO MARCELO DANZA GANDINI

Aplicação de conceitos de sustentabilidade no desenvolvimento de projeto de componentes estruturais pré-fabricados com emprego de madeira de florestas plantadas
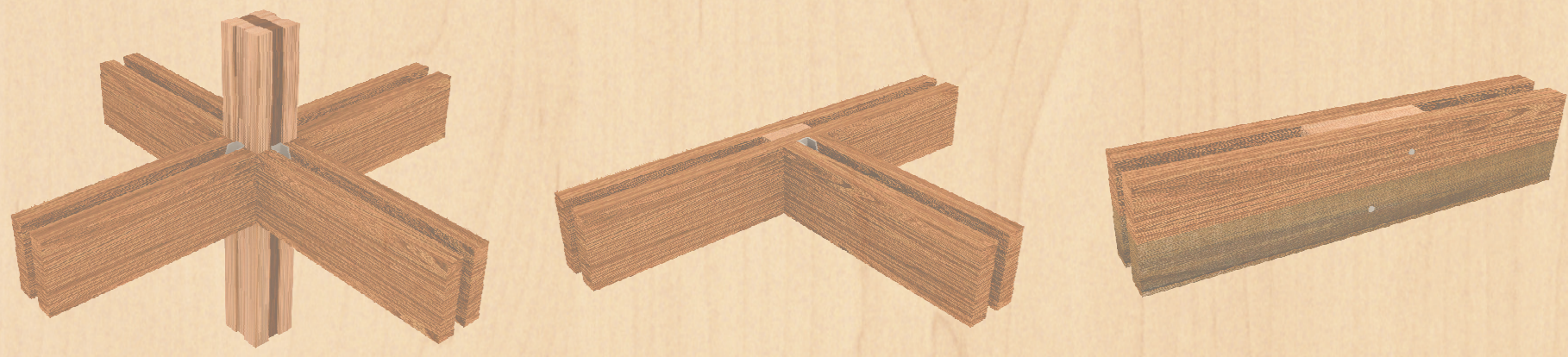

São Carlos

2016 



\section{Aplicação de conceitos de sustentabilidade no desenvolvimento de projeto de componentes estruturais pré-fabricados com emprego de madeira de florestas plantadas}

Dissertação de Mestrado apresentada ao Programa de Pós-Graduação do Instituto de Arquitetura e Urbanismo - Universidade de São Paulo para obtenção do título de Mestre em Arquitetura e Urbanismo.

Área de concentração

Arquitetura, Urbanismo e Tecnologia

Orientador: Prof. Dr. Javier Mazariegos Pablos

Co-orientador: Prof. Dr. Tomas Queiroz Ferreira Barata

"versão corrigida"

São Carlos

2016 
AUTORIZO A REPRODUÇÃO TOTAL OU PARCIAL DESTE TRABALHO, POR QUALQUER MEIO CONVENCIONAL OU ELETRÔNICO, PARA FINS DE ESTUDO E PESQUISA, DESDE QUE CITADA A FONTE.

Gandini, João Marcelo Danza
G195a Aplicação de conceitos de sustentabilidade no desenvolvimento de projeto de componentes estruturais pré-fabricados com emprego de madeira de florestas plantadas / João Marcelo Danza Gandini; orientador Javier Mazariegos Pablos; coorientador Tomas Queiroz Ferreira Barata. São Carlos, 2016.

Dissertação (Mestrado) - Programa de Pós-Graduação em Arquitetura e Urbanismo e Área de Concentração em Arquitetura, Urbanismo e Tecnologia -- Instituto de Arquitetura e Urbanismo da Universidade de São Paulo, 2016 .

1. madeira. 2. pré-fabricação. 3. sustentabilidade. I. Título. 


\section{FOLHA DE IULGAMENTO}

Candidato(a): Arquiteto e Urbanista João Marcelo Danza Gandini

Título da dissertação: "Aplicação de conceitos de sustentabilidade no desenvolvimento de projeto de componentes estruturais pré-fabricados com emprego de madeira de florestas plantadas"

Data da defesa: 05/07/2016

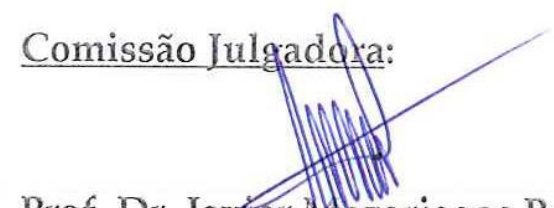

Resultado:

Prof. Dr. Javier Mazariegos Pablos

Não votante

(Instituto de) frquitetura e Urbanismo/USP)

Prof.Dyp. Akemi Ino

APROYADO

(Instityfe/de Arquitetura e Urbanismo/USP)

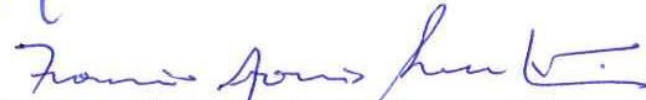

Prof. Dr. Francisco Antonio Rocco Lahr

ABROVADO

(Escola de Engenharia de São Carlos /USP)

Prot. Dr. Alexandre Jorge Duarte de Souza

(Universidade Estadual Paulista/UNESP)

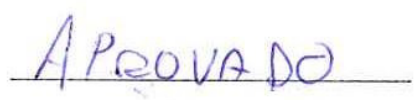

Coordenadora e Presidente da Comissão de Pós-Graduação do Programa de PósGraduação em Arquitetura e Urbanismo: Profa. Dra. Cibele Saliba Rizek. 

Ao Prof. Dr. Javier Mazariegos Pablos por ter disponibilizado seu tempo para total apoio ao presente trabalho. Sua orientação e todas as conversas tiveram uma grande importância para a evolução e aprofundamento da pesquisa.

Ao Prof. Dr. Tomas Queiroz Ferreira Barata pela amizade e por tudo o que me ensinou sobre a utilização da madeira como material construtivo. Seu incentivo e coorientação foram fundamentais para realização deste trabalho.

À Profa ${ }^{a}$. Dra ${ }^{a}$. Akemi Ino por ter aberto as portas do HABIS para que, em 2001, eu tivesse a oportunidade de iniciar meu aprendizado sobre a madeira como material construtivo.

Ao Prof. Dr. Francisco Antônio Rocco Lahr pela simpatia, amizade e pela maneira como transfere seu imenso conhecimento sobre a madeira aos seus alunos. Suas aulas sempre foram uma fonte imensa de conhecimento.

A meus pais, Angelo Gandini Neto e Anália Maria Danza Gandini, que sempre se esforçaram para que eu pudesse seguir com meus estudos e que desde menino me ensinaram a importância de valores como respeito, honestidade e lealdade, que me tornaram um homem de caráter.

À minha esposa Gilmara Lopes Aversa, por todo seu amor, carinho, paciência, incentivo e pela compreensão de minha "ausência" em todos os momentos que me mantive concentrado neste trabalho. Sem sua ajuda a conclusão deste trabalho não seria possível.

A todos que de alguma forma contribuíram para meu aprendizado sobre a madeira e para a realização deste trabalho.

Os meus sinceros agradecimentos. 

GANDINI, J. M. D. Aplicação de conceitos de sustentabilidade no desenvolvimento de projeto de componentes estruturais pré-fabricados com emprego de materiais de base florestal. 2016. Dissertação (Mestrado) - Instituto de Arquitetura e Urbanismo da Universidade de São Paulo, São Carlos - SP, 2016.

O presente trabalho visa contribuir para o desenvolvimento sustentável de produtos elaborados com materiais de base florestal e de fontes renováveis, no projeto, na produção e na montagem de componentes pré-fabricados de madeira e seus produtos derivados aplicáveis à arquitetura e construção civil. Isso se deve ao fato da atual necessidade de utilização de materiais e produtos de forma mais coerente através de tecnologias ecologicamente adaptadas para o uso de fontes energéticas renováveis, assegurando um desenvolvimento econômico socialmente responsável, com a finalidade de promover uma maior sustentabilidade no uso dos recursos naturais, principalmente no que diz respeito à construção de edificações. A base conceitual está delimitada por três aspectos fundamentais. O primeiro faz referência à problemática atual que envolve o desenvolvimento de produtos e arquitetura sustentável, considerando uma crescente preocupação quanto à possibilidade de limitação de recursos naturais disponíveis para a produção de bens materiais e os efeitos das mudanças climáticas decorrentes da degradação do meio ambiente diretamente ligada às atividades humanas. $O$ segundo aspecto trata da importância do emprego de materiais locais de fontes renováveis na produção de produtos "mais" sustentáveis. Neste sentido, aborda as características e as possibilidades do emprego da madeira de floresta plantada e materiais derivados da madeira, com o objetivo de incentivar a produção local sustentável. Também são abordados neste item, os conceitos de pré-fabricação e coordenação modular; racionalização em projeto visando a minimização do desperdício e consequentemente a geração de resíduos. Por fim, é abordada a pré-fabricação de componentes em madeira com caráter sustentável no projeto de interfaces entre componente estruturais em madeira destinados à construção de edificações.

Palavras-chave: madeira; pré-fabricação; sustentabilidade. 

GANDINI, J. M. D. Application of sustainability concepts in the development of prefabricated structural components design with the use of forest-based materials. 2016. Dissertation (Master Degree) - Instituto de Arquitetura e Urbanismo da Universidade de São Paulo, São Carlos - SP, 2016.

This work aims to contribute to the sustainable development of products made with forest-based materials and renewable sources in the design, production and assembly of prefabricated components of wood and its derivatives products applicable to architecture and construction. This is because of the current need to use materials and products more consistently through ecologically technologies adapted to the use of renewable energy sources, ensuring socially responsible economic development, with the aim of promoting more sustainable use of natural resources, particularly with regard to the construction of buildings. The conceptual basis is defined by three fundamental aspects. The first refers to the current problems involving product development and sustainable architecture, considering a growing concern about the possibility of limitation of natural resources available for the production of material goods and the effects of climate change resulting from environmental degradation directly linked to human activities. The second aspect deals with the importance of using local renewable materials in the production of products "more" sustainable. In this sense, it discusses the features and possibilities of the use of planted forest wood and materials derived from wood, in order to encourage sustainable local production. They are also covered in this item, the prefabrication of modular concepts and coordination; rationalization project aimed at minimizing waste and consequently the generation of waste. Finally, it addressed the prefabrication of wood components with sustainable character in interface design between structural component of wood for the construction of buildings.

Keywords: wood, prefabricated, sustainability 



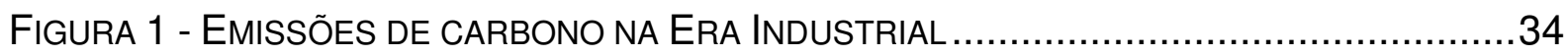

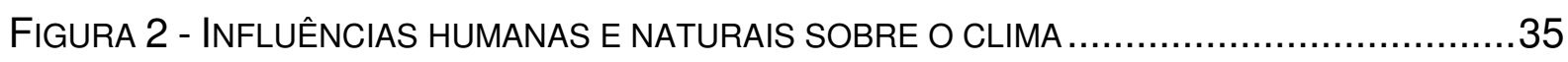

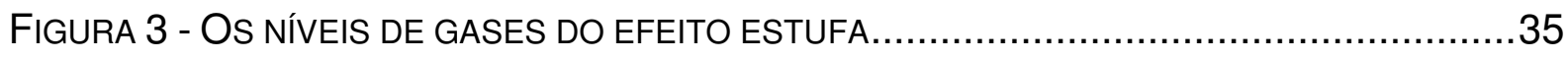

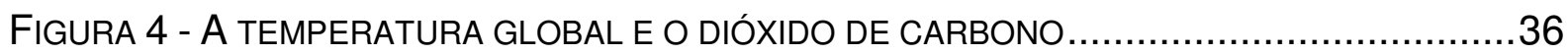

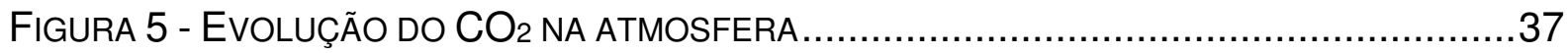

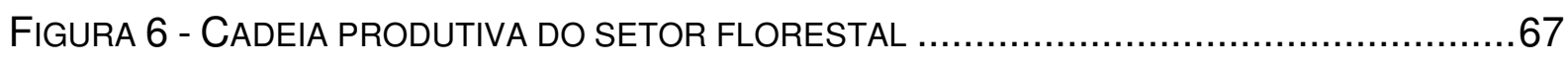

FIGURA 7 - MADEIRA NATIVA - ESTADOS DA AMAZÔNIA LEGAL ……............................72

FIGURA 8 - EstAdDOS PRODUTORES E CONSUMIDORES DA MADEIRA DA AMAZÔNIA LEGAL EM

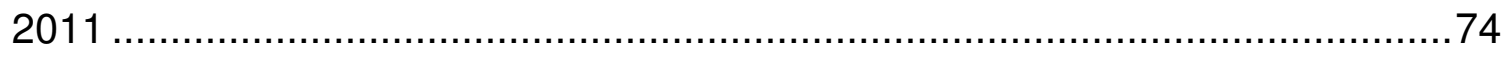

FIGURA 9 - MADEIRA PLANTADA. ESTADOS PRODUTORES DE EUCALYPTUS .......................77

FIGURA 10 - MADEIRA PLANTADA. ESTADOS PRODUTORES DE PINUS ..............................77

FIGURA 11 - DISTRIBUIÇÃO DA ÁREA DE PLANTIOS FLORESTAIS COM PINUS E EUCALYPTUS

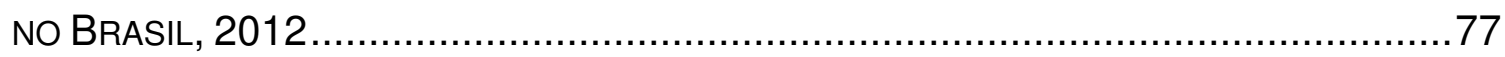

FIGURA 12 - LOCALIZAÇÃO DAS PRINCIPAIS EMPRESAS E POLOS CONSUMIDORES DE MADEIRA

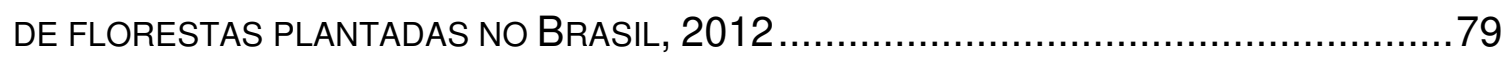

FIGURA 13 - DISTRIBUIÇÃO PROPORCIONAL DO CONSUMO DE MADEIRA DE FLORESTAS

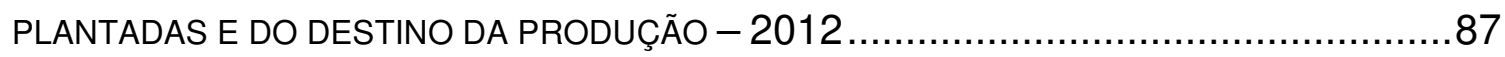

FIGURA 14 - TIPOS DE SISTEMAS CONSTRUTIVOS COM MADEIRA..................................106

FIGURA 15 - IMAFLORA I - MONTAGEM DA ESTRUTURA, VEDAÇÃO E ACABAMENTO.........109

FIGURA 16 - IMAFLORA I - PLANTA DE BARROTEAMENTO DE PISO …........................110

FIGURA 17 - IMAFLORA I - INTERFACES PILAR-FUNDAÇÃO E PILAR-VIGA COMPOSTA ......111

FIGURA 18 - IMAFLORA II - MONTAGEM DA ESTRUTURA, VEDAÇÃO E ACABAMENTO ........112

FIGURA 19 - IMAFLORA II - DETALHE PILAR COMPOSTO ….................................113

FIGURA 20 - IMAFLORA II - PLANTA DE BARROTEAMENTO DE PISO ..............................114

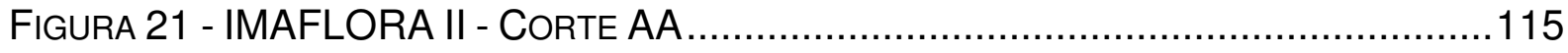

FIGURA 22 - IMAFLORA II - INTERFACE PILAR COMPOSTO-FUNDAÇÃO ……................116

FIGURA 23 - IMAFLORA II - DETALHE INTERFACE PILAR COMPOSTO - 3 VIGAS DUPLAS .. 117 FIGURA 24 - IMAFLORA II - INTERFACES PILAR-FUNDAÇÃO E PILAR-VIGA EXECUTADAS EM OBRA

FIGURA 25 - EDIFICAÇÃO SOUSAS - MAQUETE ELETRÔNICA TRIDIMENSIONAL DA EDIFICAÇÃO 
FIGURA 26 - EDIFICAÇÃO SOUSAS - MAQUETE ELETRÔNICA TRIDIMENSIONAL DA ESTRUTURA

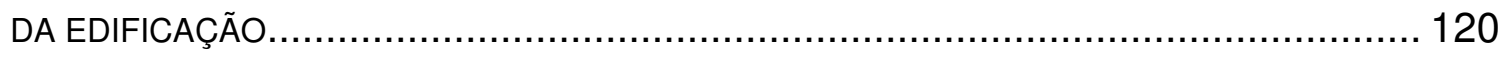

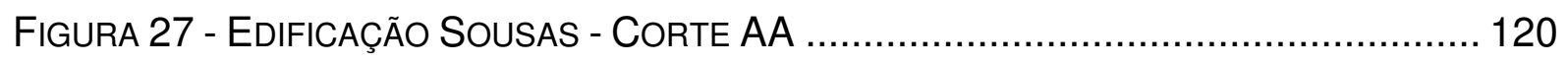

FIGURA 28 - EdIFICAÇÃo SOUSAS - PROJETO DA INTERFACE PILAR-FUNDAÇÃO .............. 121

FIGURA 29 - EdIFICAÇÃo SOUSAS - PROJETO dA INTERFACE PILAR-VIGA SIMPLES ......... 122

FIGURA 30 - EDIFICAÇÃO SOUSAS - PROJETO dA INTERFACE PILAR-VIGA DUPLA ............. 123

FIGURA 31 - SALÃO DE EVENTOS - OBRA CONCLUÍDA ……...................................... 124

FIGURA 32 - SALÃO DE EVENTOS ECOLOG - CORTE AA ……................................. 125

Figura 33 - SalÃo de EVENTOS ECOLOG - Projeto dA INTERFACE PILAR-FUnDAÇÃo . 126

FIGURA 34 - SalÃo de EVENTOS ECOLOG - Projeto dA INTERFACE PILAR-VIGA .......... 127

FIGURA 35 - SALÃO dE EVENTOS ECOLOG - INTERFACES PILAR-FUNDAÇÃO E PILAR-VIGA

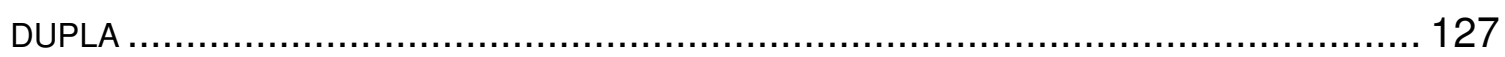




\section{LISTA DE GRÁFICOS}

GRÁFICO 1 - DISTRIBUIÇÃO DA MATRIZ ENERGÉTICA BRASILEIRA ..................................56

GRÁFICO 2 - MADEIRA DESTINADA A CARVÃO VEGETAL...........................................68

GRÁFICO 3 - MADEIRA DE EXTRATIVISMO VEGETAL E SILVICULTURA DESTINADA A LENHA....69

GRÁFICO 4 - MADEIRA DE EXTRATIVISMO VEGETAL E SILVICULTURA - MADEIRA EM TORA ....70

GRÁFICO 5 - PRODUÇÃO TOTAL DE MADEIRA SERRADA.......................................... 71

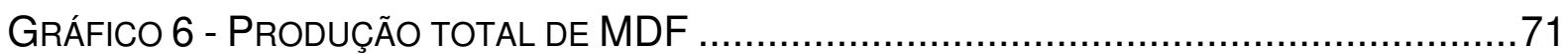

GRÁFICO 7 - COMPARAÇÃO DA PRODUTIVIDADE FLORESTAL DE CONÍFERAS E DE FOLHOSAS

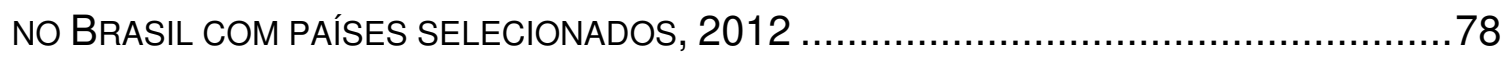

GRÁFICO 8 - MADEIRA DE EXTRATIVISMO VEGETAL E SILVICULTURA DESTINADA A CARVÃO

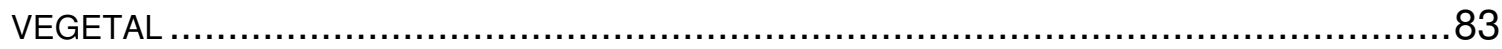

GRÁFICO 9 - MADEIRA DE EXTRATIVISMO VEGETAL E SILVICULTURA DESTINADA A LENHA....83

GRÁFICO 10 - MADEIRA EM TORA PROVENIENTE DE EXTRATIVISMO VEGETAL E SILVICULTURA

GRÁFICO 11 - ÁREA DE PLANTIOS FLORESTAIS NO BRASIL POR ESPÉCIE, 2006-2014 .......85

GráfICO 12 - PoRCENTAGEM DE FLORESTAS DE EUCALYPTUS E PINUS NO BRASIL ..........86

GRÁFICO 13 - EXTRAÇÃO ANUAL MADEIREIRA PROVENIENTE DE FLORESTAS PLANTADAS....88

GrÁFICO 14 - CARVÃo VEGETAL - PRODUÇÃo x CONSUMO INTERNO..............................89

GRÁFICO 15 - CELULOSE - ProduÇÃo x CONSUMO INTERNO......................................90

GRÁFICO 16 - PAPEL - PRODUÇÃO x CONSUMO INTERNO..........................................90

GRÁFICO 17 - PAINÉIS INDUSTRIALIZADOS - PRODUÇÃO X CONSUMO INTERNO .................91

GRÁFICO 18 - COMPENSADOS - PRODUÇÃO X CONSUMO INTERNO ..............................91

GRÁFICO 19 - SERRAdOS - PRODUÇÃo x CONSUMO INTERNO ....................................92

GRÁFICO 20 - DISTRIBUIÇÃO PERCENTUAL DAS EMISSÕES DE CO2 EM CADA FASE DO PROCESSO DA CADEIA PRODUTIVA ..............................................................94

GRÁFICO 21 - DISTRIBUIÇÃO PERCENTUAL DA ENERGIA UTILIZADA EM CADA FASE DO

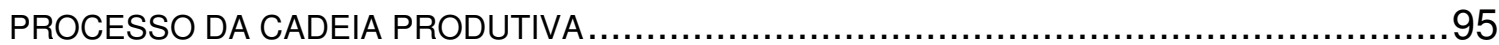





\section{LISTA DE QUADROS}

QUADRO 1 - CADEIA PRODUTIVA DA MADEIRA NATIVA ........................................ 76

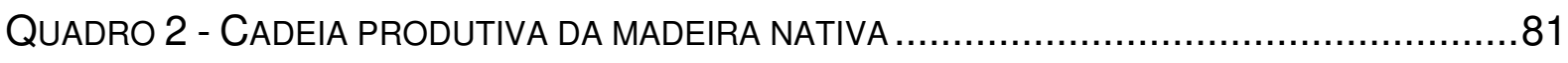

QUADRO 3 - INTERFACES PILAR-FUNDAÇÃO.................................................. 133

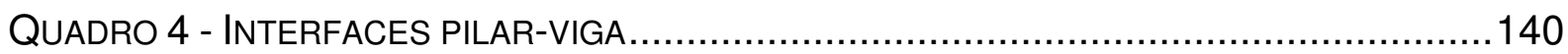

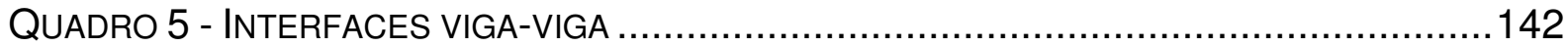



TABELA 1 - AlgunS dOS PRINCIPAIS EVENTOS RELACIONADOS A QUESTÕES DO MEIO AMBIENTE ENTRE 1972 E 2015 38

TABELA 2 - COMPOSIÇÃO MÉDIA DO ENTULHO DE OBRA NO BRASIL .43

TABELA 3 - ENERGIA NECESSÁRIA EM KWH PARA A PRODUÇÃO DE $1 \mathrm{M}^{3}$ DE COMPONENTES CONSTRUTIVOS... .57

TABELA 4 - DISTÂNCIAS PERCORRIDAS PELA MADEIRA NATIVA E PLANTADA EM KM .65

TABELA 5 - VOLUME DE COMPONENTES METÁLICOS UTILIZADOS EM CADA INTERFACE E ESTIMATIVA DE CONSUMO ENERGÉTICO PARA SUA PRODUÇÃO, TRANSPORTE E FABRICAÇÃO. 200 

CONECTOR METÁLICO PILAR-FUNDAÇÃo (T1)............................................... 145

CONECTOR METÁLICO PILAR-FUNDAÇÃO (T2) .................................................. 146

CONECTOR METÁLICO PILAR-VIGA (T3-50) ………….................................. 147

CONECTOR METÁLICO PILAR-VIGA (T3-60) ….................................................... 148

PILAR CoMPOSTO (PARA USO INTERFACE PILAR-FUNDAÇÃO 1) ............................... 150

PILAR COMPOSTO (PARA USO INTERFACE PILAR-FUNDAÇÃO 2) ................................ 153

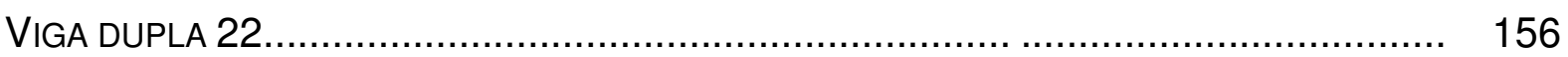

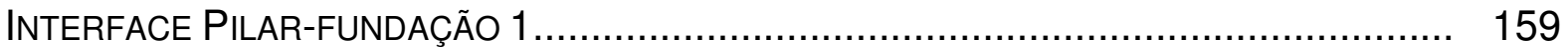

INTERFACE PILAR-FUNDAÇÃO 2 ……......................................................... 162

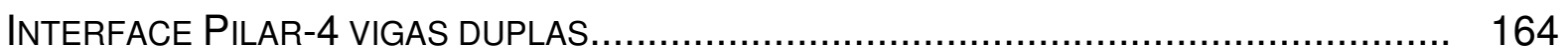

INTERFACE PILAR-3 VIGAS DUPLAS............................................................. 167

INTERFACE PILAR-3 VIGAS DUPLAS (1 PASSANTE E EM BALANÇO COM MÃO

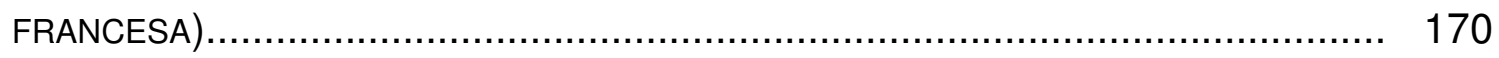

INTERFACE PILAR-2 VIGAS DUPLAS (1 PASSANTE E EM BALANÇO COM MÃO

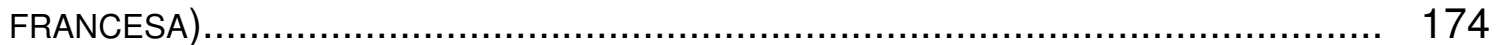

INTERFACE PILAR-2 VIGAS

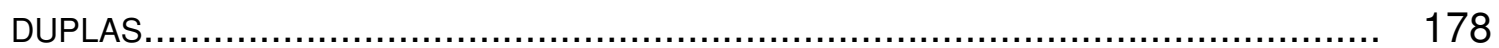

INTERFACE PILAR-2 VIGAS DUPLAS (CANTO) …........................................... 181

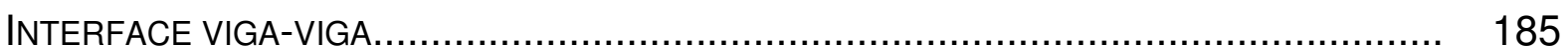

INTERFACE VIGA- 2 VIGAS.................................................................... 188

SOLIDARIZAÇÃO DE 2 VIGAS 11CM......................................................... 191

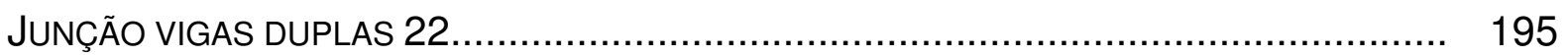

JUNÇÃO VIGAS DUPLAS (2 VIGAS 11 CM) ..................................................... 197 

ABNT - Associação Brasileira de Normas Técnicas

ABRAF - Associação Brasileira de Produtores de Florestas Plantadas

ABDI - Associação Brasileira de Desenvolvimento Industrial

ACV - Análise do Ciclo de Vida

CCA - Arseniato de Cobre Cromatado

CCB - Borato de Cobre Cromatado

CIB - Conseil International du Bâtiment

CNDB - Centro Nacional para o Desenvolvimento da Madeira da França

CONAMA - Conselho Nacional do Meio Ambiente

CRISP - Construction and City Related Sustainable Indicators

CETESB - Companhia Ambiental do Estado de São Paulo

FAO - Food and Agriculture Organization of The United Nations

FSC - Forest Stewardship Council

GEE - Gases do Efeito Estufa

IMAFLORA - Instituto de Manejo e Certificação Florestal e Agrícola

IMAZON - Instituto do Homem e Meio Ambiente da Amazônia

IPT - Instituto de Pesquisas Tecnológicas

ISO - International Organization for Standardization

JUNAC - Junta del Acuerdo de Cartagena

MDF - Medium Density Fiberboard

MDP - Medium Density Particleboard

NBR - Norma Brasileira

OSB - Oriented Strand Board

PBACV - Programa Brasileiro de Análise do Ciclo de Vida

PBTC - Peso Bruto Total Combinado

PDP - Política de Desenvolvimento Produtivo

RCD - Resíduos de Construção e Demolição

SFB - Sistema Florestal Brasileiro

SISFLOR - Sistema de Informações Florestais do Estado De São Paulo

SNIF - Sistema Nacional de Informações Florestais 

$\mathrm{cm}^{3}$ - centímetros cúbicos

ha - hectares

$\mathrm{kg}$ - quilograma

$\mathrm{km}$ - quilômetros

kWh - quiloWatt hora

$\mathrm{m}$ - metros

$\mathrm{m}^{2}$ - metros quadrados

$\mathrm{m}^{3}$ - metros cúbicos

ppb - parte por bilhão

ppm - parte por milhão 

1 INTRODUÇÃO

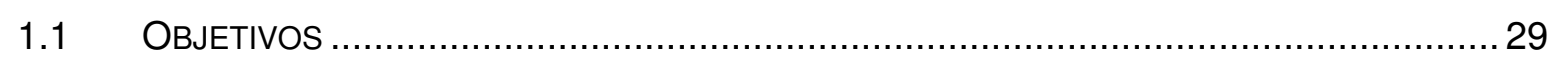

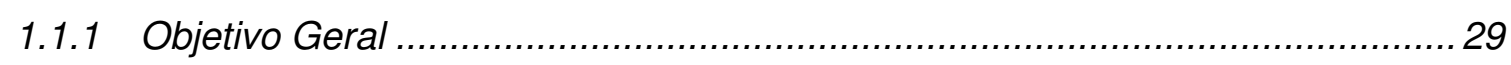

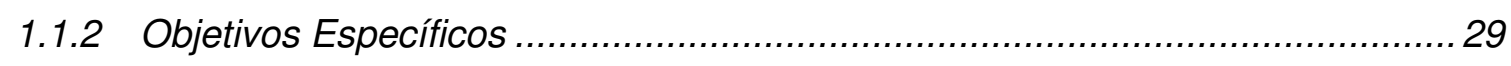

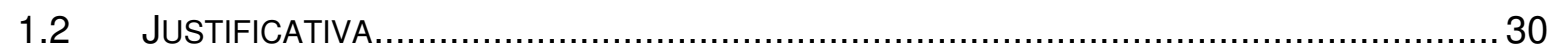

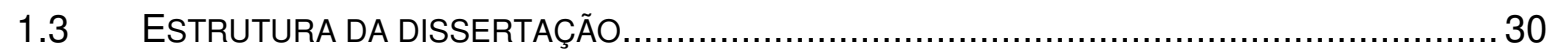

2 AS EMISSÕES DE CARBONO, AS ALTERAÇÕES CLIMÁtICAS E ESFORÇOS PARA A PROTEÇÃO DO MEIO AMBIENTE ....................................33

3 DESENVOLVIMENTO SUSTENTÁVEL ......................................................... 41

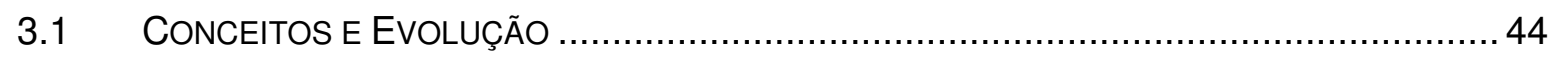

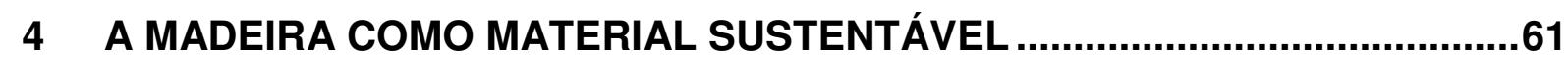

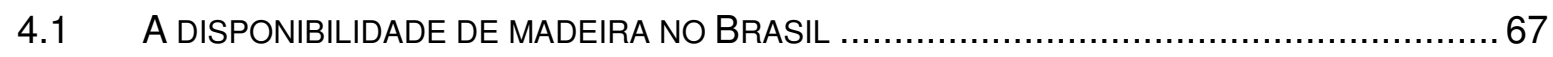

4.2 A SITUAÇÃO FLORESTAL BRASILEIRA - FLORESTAS NATIVAS E PLANTADAS ..................72

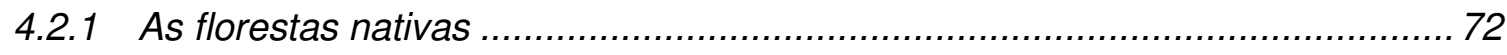

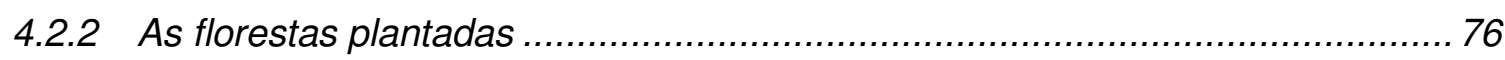

4.3 POTENCIAL DA UTILIZAÇÃO DA MADEIRA DE FLORESTAS PLANTADAS ……………...... 82

4.4 PRODUÇÃO E CONSUMO DE MADEIRA PROVENIENTE DE FLORESTAS PLANTADAS .........86

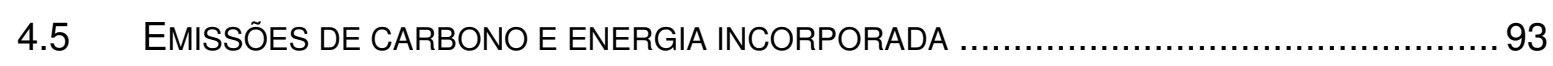

4.6 TRATAMENTO PRESERVATIVO EM MADEIRAS ORIUNDAS DE FLORESTAS PLANTADAS....95

5 COORDENAÇÃo MODULAR E SISTEMAS CONSTRUTIVOS COM COMPONENTES PRÉ-FABRICADOS EM MADEIRA ......................................101

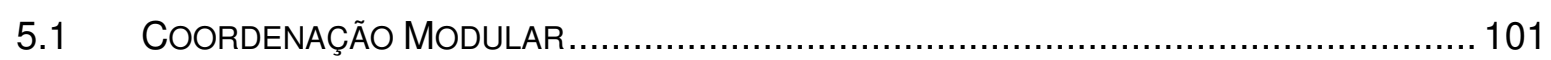

5.2 SISTEMAS CONSTRUTIVOS COM COMPONENTES PRÉ-FABRICADOS EM MADEIRA ….... 103

5.2.1 Edificações com componentes estruturais pré-fabricados de madeira............. 107

5.2.2 Levantamento e análise de Interfaces ....................................................... 128

6 PROPOSTAS DE INTERFACES E COMPONENTES ESTRUTURAIS EM MADEIRA

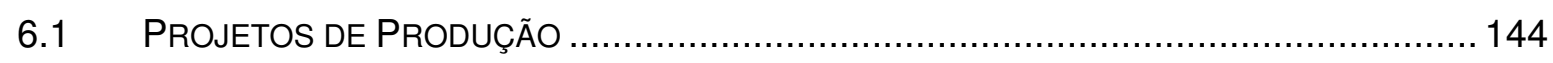

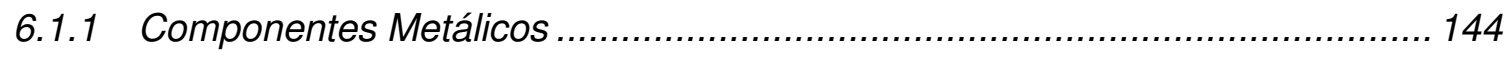

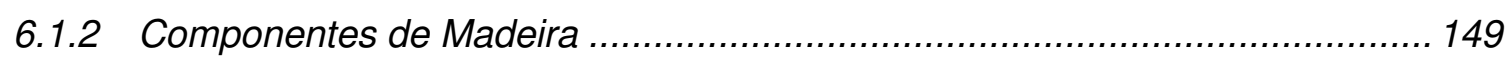

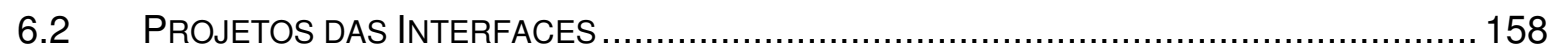




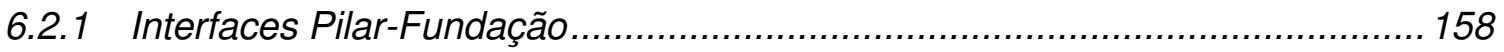

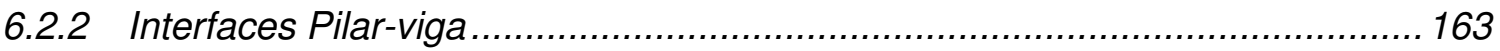

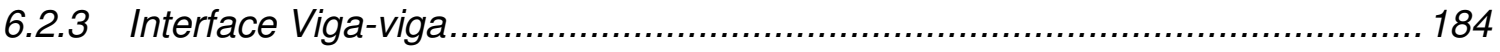

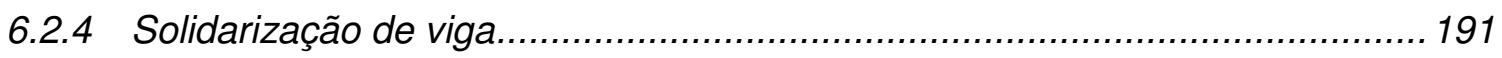

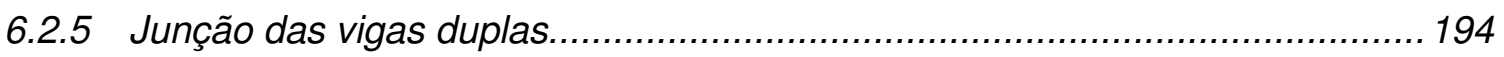

6.3 TABELA DE VOLUME E CONSUMO ENERGÉTICO PARA A PRODUÇÃO DE COMPONENTES

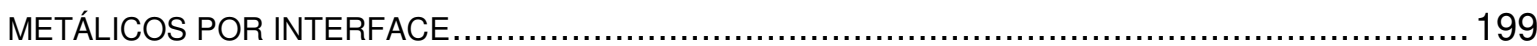

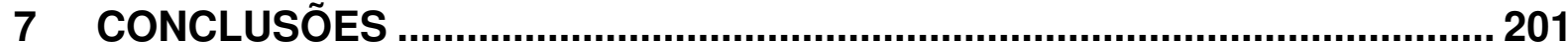

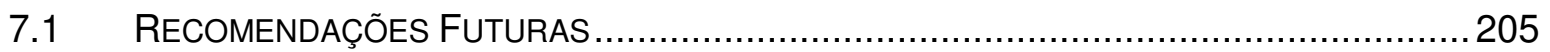

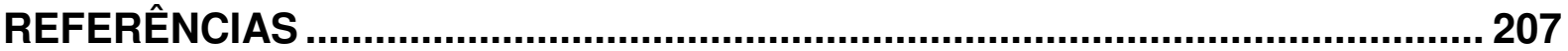

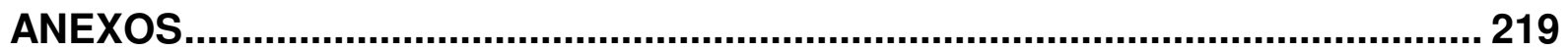




\section{INTRODUÇÃO}

"A busca da qualidade ambiental é uma atitude ancestral que visa
estabelecer um equilíbrio harmonioso entre o homem e a natureza que o
cerca. Praticada por necessidade durante séculos, em particular na
arquitetura doméstica e vernacular, caiu em desuso após a Revolução
Industrial, em uma época em que o homem acreditou na sua onipotência e
explorou, sem controle, os recursos do planeta". (GAUZIN-MULLER, 2011,
p. 26)

Hoje, as alterações climáticas iniciadas no século $X X$ tornam-se cada vez mais evidentes e representam um dos maiores desafios ambientais do século XXI, sendo que a degradação do meio ambiente está diretamente ligada às atividades humanas, como o aumento de emissão de gases do efeito estufa (GEE) gerado principalmente pela queima de combustíveis fósseis.

Segundo Boff (2012), umas das palavras mais utilizadas na atualidade é sustentabilidade, tanto por empresas, profissionais e meios de comunicação, sendo uma etiqueta aplicada a produtos e processos no intuito de agregar-lhes valor.

A sustentabilidade começou como uma moda e hoje é estratégia de negócio. Este conceito tem sido um tema altamente discutido em nível mundial juntamente com o aquecimento global, abrangendo diversos campos como a construção civil, arquitetura, indústrias, dentre outros. Contudo, as agressões à natureza e ao meio ambiente são comumente omitidas pela utilização do substantivo sustentabilidade, bem como a utilização de produtos tóxicos em alguma etapa do ciclo de vida de produtos e/ou destinação de resíduos, algumas vezes não degradáveis. Isto reflete a dinâmica global, algumas vezes contrariada por atitudes localizadas, realmente sustentáveis, na gestão de energia, uso dos recursos hídricos, atividades de reflorestamento e utilização de produtos e processos realmente sustentáveis.

A madeira tem-se revelado um material bastante promissor no Brasil, contudo, a utilização de madeiras nativas requer, além da certificação das áreas de manejo ${ }^{1}$, um estudo mais aprofundado no que diz respeito ao consumo energético

\footnotetext{
1 Cerca de $86 \%$ dos planos de manejo são considerados de média ou baixa qualidade. A tecnologia e mão de obra não tem qualificação, faltam equipes e trabalhadores, a implantação de novas tecnologias possui dificuldades logísticas, boa parte das carretas são inadequadas, os custos do transporte e a manutenção da certificação são altos, falta equipe de fiscalização, existe uma concorrência desleal por parte de produtores legais e ilegais, dificuldade de identificação das espécies (existem cerca de 14.000 espécies brasileiras catalogadas, mas comercialmente se utilizam cerca de 350), principalmente após a extração, o que aumenta os problemas de fiscalização.(PUNHAGUI, 2014)
} 
Introdução

entre o corte e o produto final, devido ao fato das reservas se concentrarem principalmente na floresta amazônica, o que aumenta significativamente o gasto energético no transporte do material, realizado por via rodoviária até os centros de consumo, fazendo sentido sua utilização somente em locais próximos à região Norte do país.

Outro fator que deve ser levado em consideração é que são disponibilizadas no mercado nacional somente madeiras de segunda ou terceira categoria, enquanto que as de primeira categoria são exportadas (PUNHAGUI, 2014).

Dentro deste raciocínio, a utilização de madeiras provenientes de áreas plantadas se torna uma alternativa mais sustentável, uma vez que seu ciclo de renovação é mais curto que o das madeiras nativas, as distâncias dos locais de plantio aos centros consumidores são menores, além da mecanização da produção e incorporação de maior tecnologia.

Além disso, o aproveitamento integral da matéria-prima madeira através de processos industriais aparece como importante fator na sua transformação em lâminas e painéis, onde a utilização de colas e vernizes adequados e de baixa toxidade pode dar origem a complexas estruturas, painéis de fechamento e coberturas. Tal fato é de extrema importância na cadeia sustentável, pois a madeira industrializada não encerra seu ciclo na desmontagem da obra, podendo ser considerada matéria-prima para reutilização, evitando-se assim desperdícios e geração de resíduos durante o processo.

A industrialização supre também o lado social do tripé sustentável (meio ambiente, promoção social, promoção econômica), pois não requer uma mão-deobra totalmente especializada, treinada e qualificada para as operações, gerando oportunidades de crescimento profissional. Segundo Agopyan e John (2011), o tripé sustentável deve ser considerado de maneira integrada, pois ao contrário, não será possível o alcance do desenvolvimento sustentável, pois "o desafio é fazer a economia evoluir, atendendo às expectativas da sociedade e mantendo o ambiente sadio para esta e para futuras gerações".

A construção civil é um segmento que tem muito a contribuir com o caráter sustentável na obtenção, gestão e utilização dos materiais, principalmente na busca de alternativas para o desperdício praticado nos canteiros de obras dos sistemas tradicionais de construção, que têm como características principais a lentidão no processo construtivo, desperdício de materiais e consequentemente a geração de 
resíduos. O combate ao desperdício se dá ainda durante o processo produtivo, pela adoção de tecnologias menos intensivas em energia e que requeiram menos matérias-primas.

Uma análise da cadeia produtiva da madeira como matéria-prima na construção de edificações com a utilização de sistemas industrializados, bem como estudos a respeito da implantação de coordenação modular são necessários para a otimização do uso de materiais que podem contribuir de forma substancial para o desenvolvimento sustentável, com ênfase na redução da emissão de carbono na atmosfera, redução e reaproveitamento de resíduos gerados nas unidades de préfabricação e nos locais da obra, geralmente descartados sem nenhum tipo de controle ambiental.

\subsection{OBJETIVOS}

\subsubsection{Objetivo Geral}

A pesquisa tem como objetivo geral o desenvolvimento de projeto executivo de componentes estruturais de Eucalyptus e as interfaces entre pilar-fundação e pilar-viga e viga-viga. O intuito é contribuir para uma maior eficiência energética na construção de edificações, tanto na etapa de produção de componentes, quanto na etapa de construção e montagem com a aplicação de conceitos de sustentabilidade, visando uma arquitetura mais sustentável.

\subsubsection{Objetivos Específicos}

- Estudar metodologias relacionadas à aplicação de conceitos de sustentabilidade na arquitetura e no projeto de componentes estruturais;

- Analisar e caracterizar produtos de base florestal visando possíveis aplicações no projeto dos componentes estruturais;

- Elaborar o projeto executivo de componentes estruturais que incorporem conceitos de sustentabilidade, no intuito de reduzir desperdícios e geração de resíduos nos processos de pré-fabricação e montagem; 
- Desenvolver a modelagem virtual dos componentes estruturais analisados e suas interfaces.

\subsection{JUSTIFICATIVA}

A principal justificativa para a realização das atividades de pesquisa propostas é a atual necessidade de utilização de materiais e produtos de forma mais coerente através de tecnologias ecologicamente adaptadas para o uso de fontes energéticas renováveis, assegurando um desenvolvimento econômico socialmente responsável, com a finalidade de promover uma maior sustentabilidade no uso dos recursos naturais, principalmente no que diz respeito à construção de edificações. Desta forma, o trabalho visa a contribuir para o desenvolvimento de produtos elaborados com materiais de base florestal e de fontes renováveis com elevado detalhamento do projeto de interfaces e no projeto da produção de componentes estruturais préfabricados de madeira aplicáveis à arquitetura e construção civil.

\subsection{ESTRUTURA DA DISSERTAÇÃO}

A presente dissertação encontra-se organizada em 6 capítulos, descritos a seguir de forma sucinta.

- No capítulo 1 é realizado um enquadramento ao tema, seus objetivos e a justificativa para o tema proposto para a dissertação.

- No capítulo 2 são apresentados dados e realizadas algumas análises a respeito das emissões de carbono e outros gases para a atmosfera, que vêm contribuindo para as alterações climáticas do planeta, decorrentes da ação do ser humano e exploração dos recursos naturais de forma indiscriminada. São descritas também as bases e esforços para o alcance da sustentabilidade através da realização de diversas conferências pela Organização das Nações Unidas (ONU) ao longo dos anos. São citados também alguns documentos gerados em tais conferências com o intuito de propor uma redução na emissão de gases do efeito estufa e preservação ambiental, como por exemplo o Protocolo de Kyoto, a Carta da Terra, a Declaração de Princípios sobre Florestas, as Agendas 21 (global e locais). 
- No capítulo 3 é discutido o conceito de desenvolvimento sustentável e sua evolução, principalmente relacionado ao setor da construção, tanto no que diz respeito ao consumo de materiais quanto a geração de resíduos, ambos responsáveis por um grande consumo de energia e emissões de carbono para a atmosfera. São discutidos também, o conceito de edificação sustentável, a implementação de estratégias nas diversas etapas de empreendimentos para sua maior sustentabilidade além de comentários acerca da utilização de produtos de base florestal, sua contribuição para a redução de gases do efeito estufa e o custo energético de sua produção e consumo para construção de edificações.

- No capítulo 4 são apresentados dados sobre florestas nativas e plantadas; aprofundadas as discussões sobre a madeira como material sustentável; as emissões de carbono resultantes dos processos de extração, processamento e transporte e a cadeia produtiva da madeira, seus principais produtos e serviços. Além disso são discutidos dados estatísticos sobre a disponibilidade, utilização, produção e consumo de madeira, abordando aspectos referentes ao potencial da utilização da madeira de florestas plantadas, seus níveis de emissão de carbono para a atmosfera e energia incorporada e, por fim, dados referentes ao tratamento químico preservativo para a madeira de florestas plantadas.

- No capítulo 5 são apresentadas as definições sobre a coordenação modular e sua importância para o caráter sustentável na obtenção, gestão e utilização dos materiais. São abordados aspectos sobre sistemas construtivos com componentes pré-fabricados em madeira e seus níveis de industrialização, bem como a apresentação de algumas edificações que possuem sistema construtivo estrutural pré-fabricado em madeira, com ênfase para o detalhe das interfaces entre pilar-fundação e pilar-viga utilizadas. Por fim são apresentados detalhes de interfaces entre pilar-fundação e pilar-viga consagradas ao longo da história. Para todas as interfaces foram inseridos comentários acerca de seus processos de usinagem, montagem em obra, utilização de ferragens e componentes metálicos e absorção de erros na montagem. 
- No capítulo 6 são apresentadas as propostas de interfaces e componentes estruturais em madeira, contendo os projetos de produção dos componentes estruturais de madeira e componentes metálicos utilizados, o projeto completo das interfaces entre pilar-fundação e pilar-viga e algumas suas variações, incluindo as imagens renderizadas tridimensionais das referidas interfaces. Foi elaborada também uma tabela de volume e consumo de componentes metálicos utilizados por tipo de interface e uma estimativa de consumo energético para a produção dos mesmos.

- No capítulo 7 são apresentadas discussões e conclusões acerca da pesquisa realizada, bem como sugestões para futuros trabalhos. 


\section{AS EMISSÕES DE CARBONO, AS ALTERAÇÕES CLIMÁTICAS E ESFORÇOS PARA A PROTEÇÃO DO MEIO AMBIENTE}

Um dos grandes problemas com que o planeta Terra se depara está relacionado com o aumento da temperatura média do ar que, por sua vez, está diretamente relacionado com a concentração de dióxido carbono $\left(\mathrm{CO}_{2}\right)$ na atmosfera (TORGAL; JALALI, 2010).

Inúmeras pesquisas têm demonstrado que já não é mais possível explicar as alterações climáticas (aquecimento global) levando-se em conta somente aspectos naturais, como por exemplo, a energia solar e vulcânica. As atividades humanas têm participação fundamental em tais alterações, devido à queima de combustíveis fosseis, carvão, gás e produção de cimento $^{2}$, principalmente após a Revolução Industrial ( 1750), promovendo um aumento dos níveis de emissão de $\mathrm{CO}_{2}$ na atmosfera, contribuindo para um aumento da temperatura do planeta.

As emissões de carbono resultantes da queima de carvão, petróleo, gás e produção de cimento entre 1850 e 2009 são apresentadas na Figura 1, sendo que tais emissões representam cerca de $80 \%$ das emissões totais de carbono de atividades humanas (78\% pela queima de combustíveis fósseis e $2 \%$ pela produção de cimento). As $20 \%$ restantes são representadas pelas mudanças de uso da terra (como a derrubada das florestas) nas últimas décadas (MELILLO et al., 2014).

\footnotetext{
2 O cimento Portland é o material artificial de maior consumo pelo homem. Na década de 30, tal consumo era inferior a $40 \mathrm{~kg} / \mathrm{hab}$.ano e em 2008 este valor passou para $422 \mathrm{~kg} / \mathrm{hab}$.ano, sendo que atualmente é maior que o consumo de alimentos. (AGOPYAN e JOHN, 2011)
} 


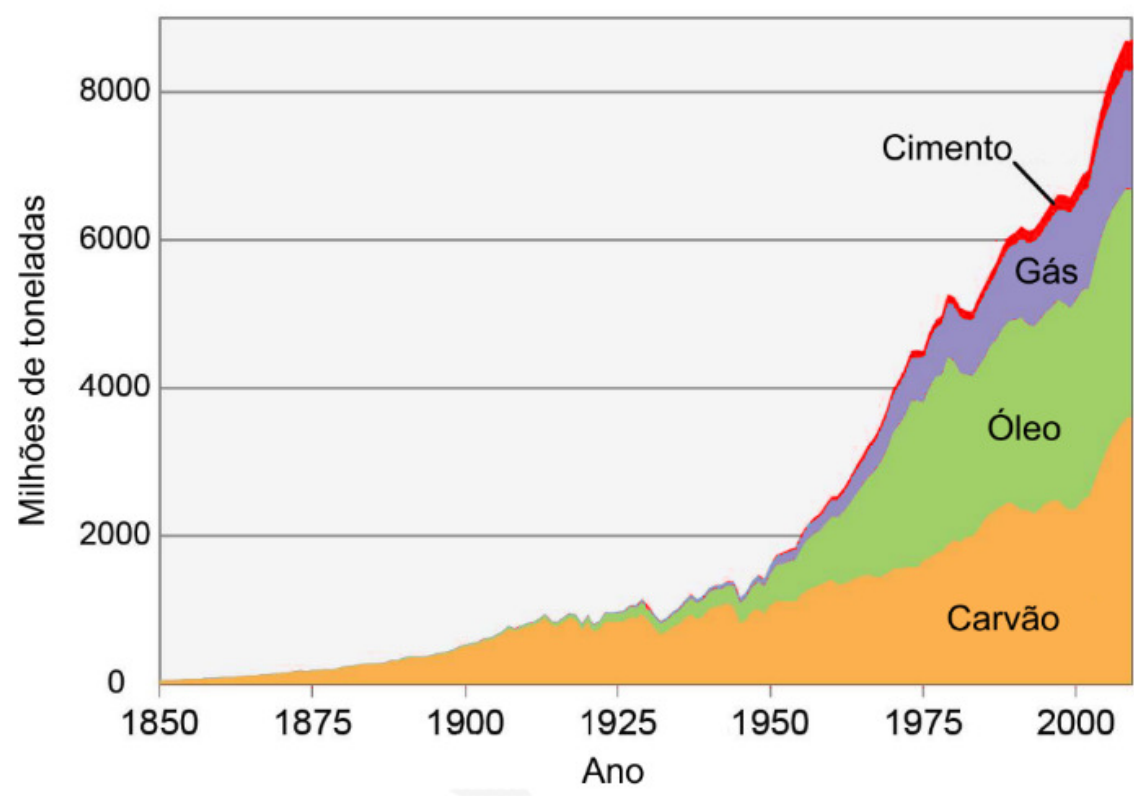

Figura 1 - Emissões de carbono na Era Industrial Fonte: Adaptado de Melillo et al. (2014)

Segundo Melillo et al. (2014), após 1960, as mudanças climáticas não podem ser explicadas, exclusivamente, por fatores naturais ou variabilidade, mas somente com a inserção das atividades humanas.

As influências humanas e naturais sobre o clima são apresentadas na Figura 2, sendo que na linha preta são mostradas as mudanças médias globais observadas; na faixa verde uma simulação por modelos climáticos de como a temperatura global média teria mudado ao longo do século passado devido a forças naturais por si só; e na faixa azul, simulações dos efeitos das forças naturais e humanas (incluindo a atividade solar e vulcânica) combinadas.

Já na conferência sobre o aquecimento global realizada em Estocolmo, em 2013, cientistas e representantes governamentais debateram um relatório sobre as recentes alterações climáticas e o documento final classifica como "extremamente provável" (95\% de confiança) que mais de metade da subida do termômetro global desde 1950 se deve às atividades humanas (GARCIA, 2013). Justamente a partir dessa data verifica-se, na Figura 1, um crescimento exponencial das emissões de carbono para a atmosfera, fato que comprova a afirmação acima. 


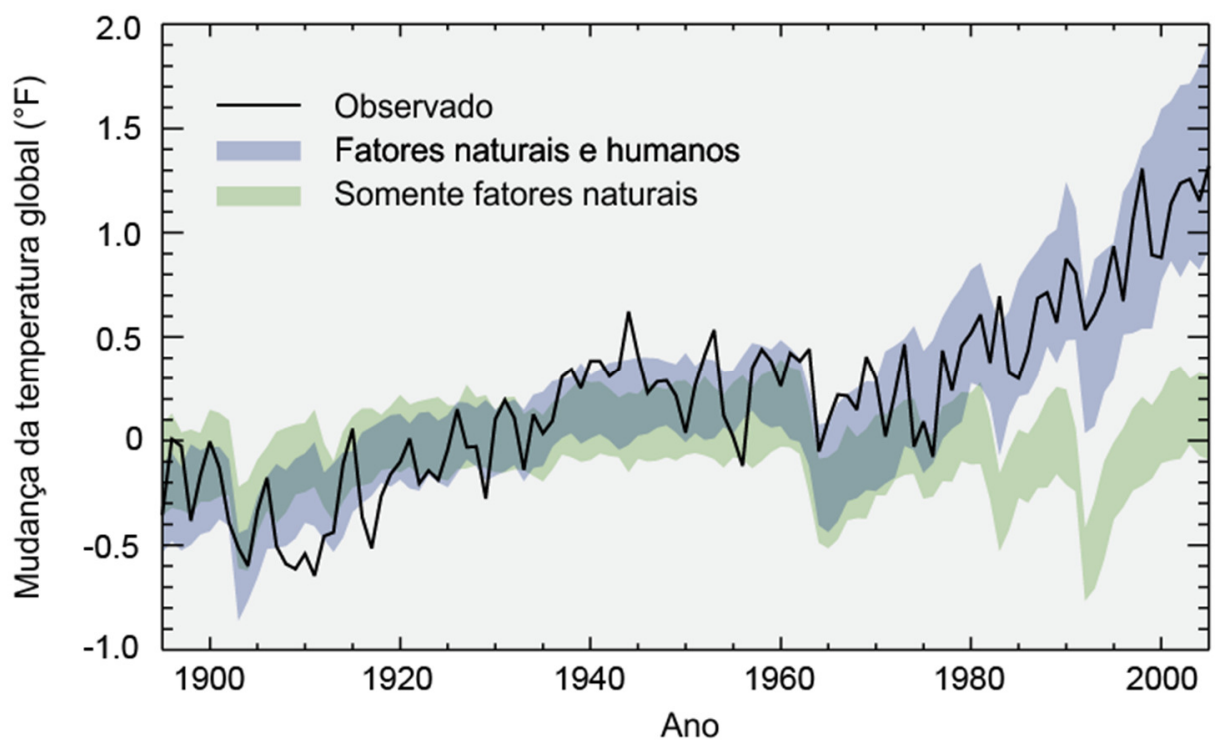

Figura 2 - Influências humanas e naturais sobre o clima Fonte: Adaptado de Melillo et al. (2014)

Os dados apresentados na Figura 3 vêm ao encontro a esse fato, uma vez que nela é apresentado o aumento das concentrações de gases de efeito estufa na atmosfera ao longo dos últimos 2.000 anos. As unidades de concentração são apresentadas em partes por milhão (ppm) ou partes por bilhão (ppb), indicando o número de moléculas de gás de efeito estufa por milhão ou bilhão de moléculas de ar. Os atuais níveis atmosféricos de dióxido de carbono, metano e óxido nitroso são notavelmente mais elevadas do que suas médias pré-industriais.

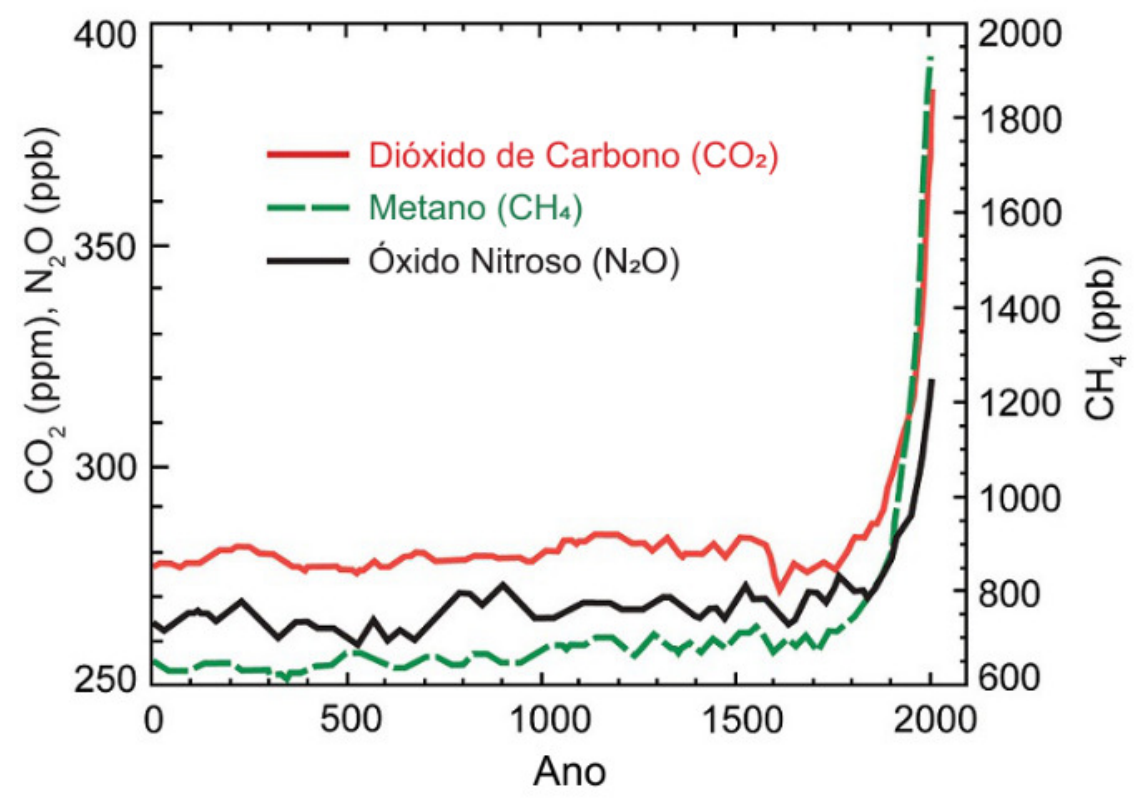

Figura 3 - Os níveis de gases do efeito estufa Fonte: Adaptado de Forster et al. (2007) 
A temperatura média anual global (medida sobre terra e oceano) aumentou em mais de $1,5^{\circ} \mathrm{F}\left(0,8^{\circ} \mathrm{C}\right)$ desde 1880 (até 2012) conforme verificado na Figura 4. As barras vermelhas e azuis mostram temperaturas acima e abaixo da média de longo prazo respectivamente. A linha preta mostra a concentração atmosférica dióxido de carbono $\left(\mathrm{CO}_{2}\right)$ em partes por milhão (ppm). Percebe-se que, embora haja uma tendência de aquecimento global clara, alguns anos não mostram um aumento de temperatura em relação ao ano anterior, e alguns anos mostram mudanças maiores do que outros. Estas flutuações na temperatura de ano para ano são devidas a processos naturais, tais como os efeitos de El Niño, La Niña e erupções vulcânicas. (MELILLO et al., 2014)

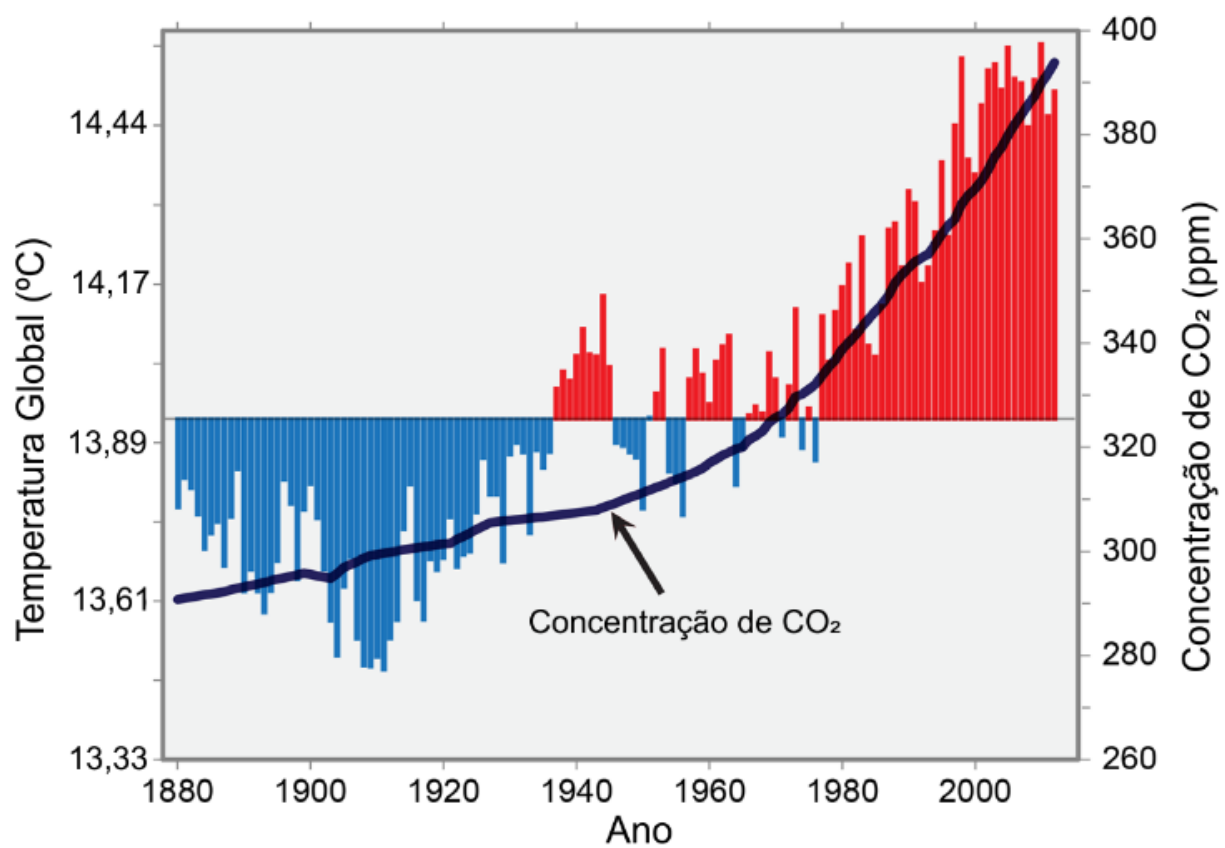

Figura 4 - A temperatura global e o dióxido de carbono Fonte: Adaptada de Karl et al. (2009)

Torgal e Jalali (2010) também apontam uma relação direta entre os níveis de $\mathrm{CO}_{2}$ presentes na atmosfera com o aumento da temperatura média global. Na Figura 5 pode-se perceber uma constante elevação tanto dos níveis de carbono quanto da temperatura global média a partir do início do século $\mathrm{XX}$. De todo o volume de $\mathrm{CO}_{2}$ emitido para a atmosfera, segundo os autores, aproximadamente $70 \%$ são provenientes da queima de combustíveis fósseis. 


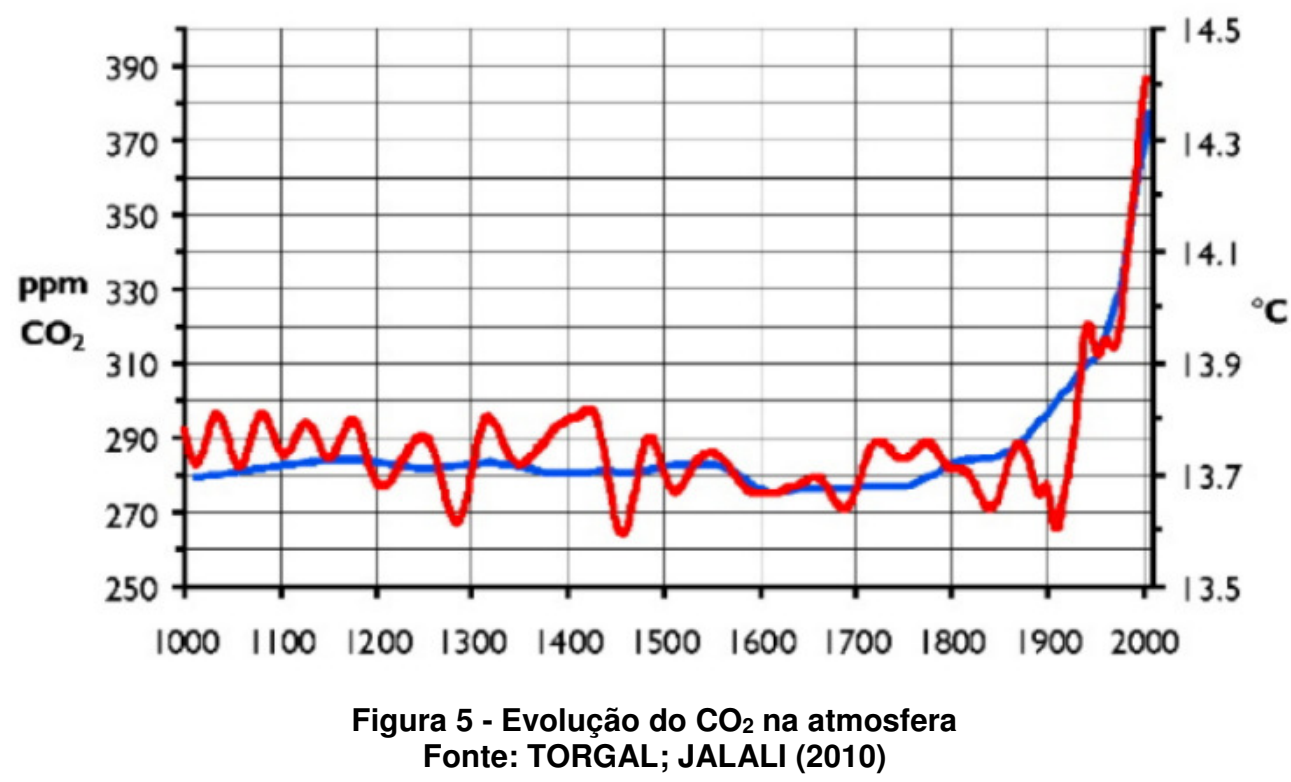

Os sinais do crescente aquecimento global associado às emissões de $\mathrm{CO}_{2}$ para atmosfera, está ligada a fatores conhecidos, tais como consumo desmesurado de recursos não renováveis, destruição das florestas, proliferação de aterros sanitários, uso de produtos químicos, poluição gerada pela atividade humana, utilização de combustíveis fósseis, entre outros.

Segundo Mourão e Pedro ${ }^{3}$, (2012 apud REIS, 2015. p. 1) as alterações climáticas globais, o esgotamento de recursos, a poluição, a destruição dos ecossistemas, a extinção das espécies, a deterioração da qualidade de vida, a iniquidade no acesso a recursos e ao conhecimento demonstram que os padrões que regem as atividades humanas tornaram-se insustentáveis.

Desde os primórdios da Humanidade, até a um passado recente, o ser humano conviveu com a ideia de um mundo com capacidade regenerativa inesgotável e recursos intermináveis (REIS, 2015).

O debate sobre o meio ambiente não é recente, tendo começado há décadas com discussões sobre o uso de pesticidas nos anos 60, a crise do petróleo nos anos 70 e a realização da primeira conferência das Nações Unidas em 1972, contudo, o conceito de desenvolvimento sustentável passou a ser conhecido a partir da apresentação do documento intitulado Our Common Future (Nosso Futuro Comum) ou Relatório Brundtland, na Conferência das Nações Unidas sobre o Meio-ambiente

${ }^{3}$ MOURÃO, J.; PEDRO, J. B. Princípios de Edificação Sustentável. Lisboa: LNEC, 2012. 
Humano - The United Nations Conference on the Human Environment, que aconteceu em Estocolmo em 1987 e contou com a participação de 133 países.

O relatório apresentou um novo olhar sobre o desenvolvimento, definindo-o como o processo que "satisfaz as necessidades presentes, sem comprometer a capacidade das gerações futuras de suprir suas próprias necessidades". A sua aceitação pela Assembleia Geral da Organização das Nações Unidas (ONU) the conferiu relevância política ampliando as discussões sobre o meio ambiente. Os principais eventos relacionados ao meio ambiente são apresentados na Tabela 1.

Tabela 1 - Alguns dos principais eventos relacionados a questões do meio ambiente entre 1972 e 2015

\begin{tabular}{c|l}
\hline Ano & \multicolumn{1}{|c}{ Evento } \\
\hline 1972 & $\begin{array}{l}\text { Primeira Conferência das Nações Unidas sobre o Meio Ambiente } \\
\text { Humano (Estocolmo) }\end{array}$ \\
\hline 1972 & $\begin{array}{l}\text { Criação do UNEP - Programa das Nações Unidas sobre o Meio } \\
\text { Ambiente }\end{array}$ \\
\hline 1985 & Convenção de Viena para a proteção da camada de ozônio (Viena) \\
\hline 1987 & $\begin{array}{l}\text { Protocolo de Montreal relativo a substâncias que agridem a camada } \\
\text { de ozônio (Montreal) }\end{array}$ \\
\hline 1988 & $\begin{array}{l}\text { Criação do IPCC - Painel Intergovernamental sobre as Mudanças } \\
\text { Climáticas }\end{array}$ \\
\hline 1992 & Rio-92 ou Eco-92 (Rio de Janeiro) \\
\hline 1996 & $\begin{array}{l}\text { Habitat II - Segunda Conferência das Nações Unidas sobre os } \\
\text { Assentamentos Humanos (Estambul), }\end{array}$ \\
\hline 1997 & Protocolo de Kyoto \\
\hline 2002 & $\begin{array}{l}\text { Rio+10, Conferência das Nações Unidas sobre o desenvolvimento } \\
\text { sustentável (Johanesburgo) }\end{array}$ \\
\hline 2009 & Conferência Mundial sobre o Clima, COP 15 (Copenhagen) \\
\hline 2012 & $\begin{array}{l}\text { Rio+20, Conferência das Nações Unidas sobre o desenvolvimento } \\
\text { sustentável (Rio de Janeiro) }\end{array}$ \\
\hline 2013 & Conferência sobre Aquecimento Global (Estocolmo) \\
\hline 2015 & $21^{a}$ Conferência Mundial sobre o Clima, COP 21 (Paris) \\
\hline
\end{tabular}

Fonte: Adaptada de PUNHAGUI (2014)

Segundo a ONU, por meio do Protocolo de Kyoto, no primeiro período de compromisso, 37 países industrializados e a Comunidade Europeia comprometeram-se a reduzir as emissões de gases de efeito estufa para uma média de $5 \%$ em relação aos níveis de 1990. Durante o segundo período de compromisso, as partes se comprometeram a reduzir as emissões de GEE em pelo menos $18 \%$ abaixo dos níveis de 1990 no período de oito anos 2013 a 2020 (UNFCCC - United Nations - Framework Convention on Climate Change). 
A Conferência das Nações Unidas sobre Meio Ambiente e Desenvolvimento ocorrida no Rio de Janeiro em 1992, conhecida como Rio 92 ou Eco 92, teve grande importância, pois contou com a participação de mais de 170 países, além do fato de que nessa conferência líderes mundiais estabeleceram os princípios do desenvolvimento sustentável dando origem a documentos como a Declaração do Rio, Declaração de Princípios sobre Florestas, propostas para a elaboração da Carta da Terra (ratificada em março de 2000) e que propiciaram também a assinatura de um documento chamado de Agenda 21.

Este último reflete um consenso mundial sobre a importância de cada país se comprometer a pensar, global e localmente, no que diz respeito ao desenvolvimento e cooperação ambiental, de modo a que seja possível satisfazer as necessidades básicas, elevar o nível de vida de todos e obter ecossistemas melhor protegidos e geridos em prol do desenvolvimento sustentável. A Agenda 21 segue o princípio "Pensar globalmente, agir localmente". Este é sem dúvida o resultado mais importante da conferência do Rio (REIS, 2015).

Entre as medidas apontadas pelo relatório final da conferência, constam soluções como a diminuição do consumo de energia, o desenvolvimento de tecnologias para uso de fontes energéticas renováveis e o aumento da produção industrial nos países não industrializados com base em tecnologias ecologicamente adaptadas.

Após a Rio 92 outras conferências foram realizadas com o propósito de continuidade às discussões a respeito do desenvolvimento sustentável. O principal objetivo dessas conferências foi a renovação do compromisso político com 0 desenvolvimento sustentável, por meio da avaliação do progresso e das lacunas na implementação das decisões adotadas anteriormente.

Já na Conferência da ONU sobre Mudanças Climáticas realizada em 2009 em Copenhagen (COP-15), o Brasil assumiu a liderança entre os países em desenvolvimento ao comprometer-se voluntariamente a cortar as emissões de gases de efeito estufa entre $36 \%$ e $39 \%$ em comparação com o cenário do ano vigente até 2020. Tal compromisso tornou-se lei e atualmente a Política Nacional sobre Mudanças Climáticas está sendo regulamentada. Grande parte da redução das emissões vem da redução do desmatamento, especialmente na Amazônia. 
A última conferência para discussões das questões ambientais foi a $21^{\text {a }}$ Conferência Mundial sobre o Clima (COP-21), que ocorreu em Paris em 2015 e contou com a presença de líderes de 195 países. O fórum teve como finalidade ratificar um acordo de extensão global para frear as emissões de gases do efeito estufa (GEE) e para lidar com os impactos das mudanças climáticas.

É possível afirmar que estes esforços têm contribuído de forma significativa na adoção de medidas que visam uma maior preservação dos recursos naturais disponíveis e consequentemente uma redução nos níveis de degradação ambiental; contudo, é necessária uma contínua atenção aos níveis de consumo dos recursos naturais disponíveis que vêm crescendo vertiginosamente, pois a natureza necessita de tempo para regenerar-se e recompor-se daquilo que lhe é retirado. Precisa-se, portanto, garantir a sustentabilidade geral do planeta e dos ecossistemas pois Michail Gorbachev já advertia em 2002 que:

[...]precisamos de um novo paradigma de civilização porque o atual chegou ao seu fim e exauriu suas possibilidades; temos que chegar a um consenso sobre novos valores, caso contrário em 30 ou 40 anos a Terra poderá existir sem nós (BOFF, 2012, p.26).

Tal afirmação pode ser constatada também em uma citação do investigador Norte-Americano Jonas E. Saulk: "If all the insects were to disappear from Earth, within 50 years all life on Earth would end. If all human beings disappear from the face of the Earth, in 50 years all forms of life would flourish" (TORGAL; JALALI, 2010. p. 1). 


\section{DESENVOLVIMENTO SUSTENTÁVEL}

O setor da construção tem um papel significativo no apoio aos objetivos globais para o desenvolvimento sustentável, em particular no que diz respeito à redução dos impactos ambientais. O referido setor consome $40 \%$ dos materiais e $55 \%$ das madeiras extraídas mundialmente (ROODMAN; LENSSEN, 1995), 40\% de recursos naturais, $25 \%$ de água, cerca de $40 \%$ da energia e emite aproximadamente $30 \%$ do total de gases do efeito estufa (UNEP, 2016).

Segundo Punhagui (2014), no Brasil, o setor de produção e de construção é responsável por cerca de $27 \%$ a $29 \%$ das emissões de gases do efeito estufa devido ao uso de energia. Considerando as emissões totais do país, a mudança no uso da terra e desmatamento são responsáveis por $47 \%$ a $55 \%$ das emissões de gases do efeito estufa.

A autora ressalta também que a falta de desempenho nos processos de fabricação de materiais e construção de edifícios fazem com que se consuma uma energia considerável sem qualquer utilidade, o que provoca mais emissões de gases do efeito estufa por quantidade de produto, sendo que a diminuição do consumo de energia e emissões nos processos de extração e fabricação de materiais depende do desenvolvimento tecnológico, investimento econômico e de políticas públicas.

No que diz respeito à geração de resíduos, os edifícios são responsáveis por $40 \%$ do total produzido, sendo que cerca de $92 \%$ são atribuídos às atividades de demolição e $8 \%$ têm origem nas atividades construtivas de novos edifícios ou renovações de estruturas existentes (CIB ${ }^{4}, 1999$ apud PINHEIRO, 2006. p. 19). Tal fato evidencia a importância da reutilização dos materiais após o término da vida útil das edificações, o que evita a extração e consumo de novos materiais, contribuindo para a preservação do meio ambiente.

No mundo, a produção de resíduos de construção pode variar entre cerca de 130 e $3700 \mathrm{~kg} / \mathrm{hab}$.ano, ou cerca de $100 \mathrm{~kg} / \mathrm{m}^{2}$. Para o Brasil o valor médio é de 510 kg/hab.ano e cerca de 300 kg/m² respectivamente (JOHN; AGOPYAN ${ }^{5}, 2000$ apud

\footnotetext{
${ }^{4} \mathrm{CIB}$ - Conseil International du Bâtiment. Agenda 21 on sustainable construction. CIB Publication 237, 121 p. Rotterdam, Holland, 1999.

5 JOHN, V. M.; AGOPYAN, V. Reciclagem de resíduos da construção. Seminário - Reciclagem de Resíduos Sólidos Domiciliares, 2000.
} 
PUNHAGUI, 2014. p. 4) e (MONTEIRO et $\mathrm{al}^{6}$., 2001 apud PUNHAGUI, 2014. p. 4). Considerando uma população urbana de aproximadamente 170 milhões de habitantes, estima-se uma geração de 90 milhões de toneladas anuais (AGOPYAN e JOHN, 2011).

Cerca de $50 \%$ dos resíduos sólidos urbanos é de construção e demolição (ANGULO et al. ${ }^{7}, 2011$ apud PUNHAGUI, 2014. p. 4), já no Brasil os valores estão entre 50\% a 70\% (PINTO ${ }^{8}, 2005$ apud PUNHAGUI, 2014. p. 4). Assim, pode ser visto que grande parte dos recursos naturais limitados são desperdiçados sem aplicação a curto ou a longo prazo.

Como pode ser observado, com o passar do tempo, assim como houve um gradativo aumento da preocupação ambiental passou a existir também maior produção de resíduos, devido principalmente, ao crescimento populacional e seu consumo desenfreado, tal fato contribuiu para o surgimento de técnicas de tratamento com o objetivo de reduzir sua toxidade, reduzir seu volume ou destruí-lo (SILVA, 2010). Além da quantidade de resíduos, o seu destino também é um fator preocupante e que gera inúmeros impactos ambientais, uma vez que no Brasil, segundo Punhagui (2014), resíduos de construção são depositados ilegalmente em locais públicos ou em aterros sanitários privados, criando problemas de poluição ambiental e possível contaminação por produtos químicos, entre outros.

Em termos de composição, os resíduos da construção civil são uma mistura de materiais inertes, tais como concreto, argamassa, madeira, plásticos, papelão, vidros, metais, cerâmica e terra (MONTEIRO et al., 2001). Os valores percentuais são apresentados na Tabela 2.

\footnotetext{
${ }^{6}$ MONTEIRO, J. H. P., FIGUEIREDO, C. E. M., MAGALHÃES, A. F. MELO, M. A. F., BRITO, J. C. X., ALMEIDA, T. P. F., MANSUR G. L. Manual de Gerenciamento Integrado de resíduos sólidos. IBAM, 2001.

7 ANGULO, S. C., TEIXEIRA, C. E., CASTRO, A. L., NOGUEIRA, T. P. Construction and demolition waste: evaluation of quantification methods, Engenharia Sanitaria e Ambiental, vol. 16, no 3, p. 299306, set. 2011.

8 PINTO, T. P. Gestão Ambiental de Resíduos da Construção Civil. A experiência do SindusCon-SP. Obra Limpa; I\&T; Sinduscom-SP, 2005.
} 


Tabela 2 - Composição média do entulho de obra no Br
\begin{tabular}{c|c}
\hline Componente & Valores (\%) \\
\hline Argamassa & 63,0 \\
\hline Concreto e blocos & 29,0 \\
\hline Outros & 7,0 \\
\hline Orgânicos & 1,0 \\
\hline Total & 100,0 \\
\hline
\end{tabular}

Fonte: MONTEIRO et al. (2001)

No que diz respeito ao concreto, segundo Agopyan e John (2011), em 2009 foram produzidas, no Brasil, 52 toneladas de cimento que foram misturadas a cerca de 340 milhões de toneladas de agregados, além de 36 milhões de toneladas de água.

O desenvolvimento sustentável constitui uma preocupação real para a indústria da construção, originando um esforço no sentido de transpor esse conceito para o ambiente construído, atendendo a elevada quantidade de recursos que consome, a quantidade de resíduos que produz, a sua implicação na economia dos países e a sua interrelação com a sociedade.

Percebe-se que o descarte ao final da vida útil é um dos impactos mais preocupantes na análise da cadeia produtiva de um produto. No Brasil como no resto do mundo, o problema do descarte de produtos no meio ambiente é muito preocupante, sendo a reciclagem uma alternativa para transformar resíduos sólidos em matéria-prima para outros processos produtivos, tanto para geração de energia como para servir de componentes de novos produtos (CÉSAR; CUNHA; GUEDES, 2010).

O design sustentável considera esta problemática e enfatiza o reaproveitamento de material nos processos de produção e também no momento do descarte. Conforme Teixeira e César (2004), a reciclagem abrange formas de reutilização da matéria-prima residual oriunda tanto de processos industriais quanto oriunda de produtos e bens de consumo descartados, o que ajuda não só na diminuição da demanda por recursos naturais como também na economia de energia, dependendo do material e do processo de reaproveitamento. Uma das preocupações principais da atividade de design é tentar obter soluções que combinem efetivamente o descarte e a reciclagem racionais dos componentes dos 
produtos. Dentre essas soluções está o balanceamento entre a vida útil do produto e o seu ciclo de vida.

\subsection{CONCEITOS E EVOLUÇÃO}

Segundo Corbella (2003, p. 17), o conceito de Arquitetura Sustentável pode ser entendido como: "[...] elaboração e execução de empreendimentos que visem ao aumento da qualidade de vida do ser humano quanto ao ambiente construído e ao seu entorno, integrado às características da vida e do clima locais [...]", além de um uso mais eficiente dos recursos naturais.

Já o conceito de construção sustentável foi definido por Charles Kibert em 1994, no Conselho Internacional da Construção (CIB) como: "Construção sustentável é a criação e gestão responsável de um ambiente construído saudável, tendo em consideração os princípios ecológicos e a utilização eficiente dos recursos". Com base nesta definição, o CIB definiu sete princípios para a construção sustentável (KIBERT ${ }^{9}, 2013$ apud REIS, 2015. p. 17):

- Redução do consumo de recursos;

- Reutilização de recursos;

- Utilização de recursos recicláveis;

- Proteção da natureza;

- Eliminação dos produtos tóxicos;

- Análise dos custos do ciclo de vida;

- Garantia da qualidade.

Segundo Adam (2001) a construção sustentável pode ser definida como sendo um conjunto de estratégias de utilização do solo, projeto arquitetônico e construção em si que reduzem o impacto ambiental e visam a um menor consumo de energia, à proteção dos ecossistemas e mais saúde para os ocupantes.

\footnotetext{
${ }^{9}$ KIBERT, C. J. Sustainable Construction. Green Building Design and Delivery. John Wiley \& Sonsn, Inc., v. 3, 562 p. 2013.
} 


\begin{abstract}
"A construção sustentável pode ser definida como o resultado da aplicação dos princípios do desenvolvimento sustentável ao longo de todo o ciclo de vida do empreendimento, desde a extração e beneficiamento das matérias primas, percorrendo as fases de planejamento, projeto, execução do edifício e infraestrutura até a sua demolição e gestão dos resíduos dela resultantes" (HERNANDES ${ }^{10}$, 2006; apud BARROS; FABRÍCIO, 2012); (CIB; UNEP, 2002).
\end{abstract}

Segundo Reis (2015, p. 17), a International Organization for Standardization (ISO ${ }^{11}$ ) adotou em sua Norma ISO 21929-1/2011, o conceito de construção sustentável definido por uma equipe de trabalho denominada CRISP (Construction and City Related Sustainable Indicators), com a seguinte definição:

\footnotetext{
"Com a construção sustentável pretende-se que os produtos da indústria da construção satisfaçam os requisitos funcionais com o menor impacto ambiental possível, enquanto promovem melhorias a nível econômico, social e cultural à escala local, regional e global".
}

Este último conceito demonstra-se muito mais amplo, no sentido de considerar, além do impacto ambiental das construções, o conforto dos usuários e qualidade de vida em geral da população.

De acordo com Keeler (2010, p.49), ainda que não resolva todos os problemas a edificação sustentável deve:

- Tratar das questões de demolição no terreno e de resíduos da construção, bem como dos resíduos gerados pelos usuários;

- Buscar a eficiência na utilização dos recursos, minimizar o impacto da mineração e do extrativismo na produção de materiais e contribuir na recuperação dos recursos naturais; reduzir o consumo de solo, água e energia durante a manufatura dos materiais, a construção da edificação e sua utilização por seus usuários; planejar uma baixa energia incorporada durante

\footnotetext{
10 HERNANDES, T. Z. LEED-NC como sistema de avaliação da sustentabilidade: uma perspectiva nacional?, SP.2006. 134 f. Dissertação (Mestrado em arquitetura e urbanismo) - Programa de Pós Graduação em Arquitetura e Urbanismo, Universidade de São Paulo, Faculdade de Arquitetura e Urbanismo, São Paulo, 2006.

11 ISO é uma organização internacional independente, não-governamental composta de 162 organismos de normalização. Através dos seus membros, reúne especialistas para compartilhar conhecimentos, baseados no mercado de normas internacionais que apoiam a inovação e o fornecimento de soluções para os desafios globais.
} 
o transporte dos materiais ao terreno; trabalhar de modo lógico à medida que a cadeia de produção de materiais é traçada.

- Buscar a conservação de energia e projetar visando o consumo eficiente de energia na alimentação dos sistemas de calefação, refrigeração, iluminação e elétrica. Já que a construção de edificações está entre os principais emissores de dióxido de carbono, planejar a redução de tais emissões é grande desafio e logo se tornará uma obrigação social e política inegociável;

- Oferecer um ambiente interno "saudável", ou seja: evitar o uso de materiais de construção e limpeza que emitam compostos orgânicos voláteis; evitar o uso de equipamentos que não controlem ou não filtrem de maneira adequada a entrada ou a produção de particulados; controlar a entrada de poluentes externos por meio de filtragem do ar, ventilação e capachos adequados; e de contaminantes usados pelos usuários, como em produtos de higiene pessoal e; projetar uma conexão com o exterior que forneça ventilação natural, iluminação diurna e vistas para o exterior.

$\mathrm{Na}$ perspectiva tradicional, uma construção só era competitiva se tivesse o nível de qualidade exigido pelo projeto, se utilizasse um sistema construtivo que otimizasse a produtividade durante a fase de construção e que desta forma conduzisse à diminuição do período de construção, permitindo uma maior rapidez na recuperação de investimento. Já a construção sustentável representa uma nova forma de equacionar a concepção, a construção, a operação e a desativação (PINHEIRO, 2006).

Para alcançar a sustentabilidade da construção, faz-se necessária a avaliação do ciclo de vida (ACV) dos materiais a serem utilizados ${ }^{12}$, desde a fase de projeto até a desmontagem do edifício. Para Reis (2015), torna-se necessário uma mudança nas práticas na concepção do projeto e também na construção, bem como uma melhor compreensão dos ciclos de recursos envolvidos e das necessidades e requisitos dos futuros usuários.

A avaliação do ciclo de vida tem como objetivo analisar e contabilizar a complexa interação de um sistema, podendo ser um material, um componente ou

\footnotetext{
12 O Governo Brasileiro através do Ministério do Desenvolvimento, Indústria e Comércio Exterior aprovou o PBACV - Programa Brasileiro de Análise do Ciclo de Vida (Resolução no 3 de 22 de abril de 2010), que prevê a construção de um banco de dados com informações de inventários de Ciclo de Vida de produtos.
} 
um conjunto de componentes com o ambiente, ao longo das várias fases do seu ciclo de vida (PINHEIRO, 2006). Sua aplicação, frequentemente integrada aos processos de tomada de decisões nos setores empresarial e industrial, é reconhecidamente de grande valia para o setor da construção civil. Tal situação decorre dos expressivos impactos ambientais produzidos nas diversas fases do processo construtivo (desde a fase de extração e fabricação de matérias-primas até a renovação ou demolição da estrutura), avaliados por meio das repercussões de emissões de gases para a atmosfera, consumo de recursos naturais, demandas energéticas e geração de resíduos sólidos e líquidos (SOARES; SOUZA; PEREIRA, 2006).

A sustentabilidade de um empreendimento pode ser então ser caracterizada como a implementação de estratégias desde sua concepção (etapa de projeto), passando pela fase de construção, utilização até sua desmontagem, levando em consideração a extração da matéria-prima necessária à produção dos materiais a serem utilizados, suas aplicações e posterior reutilização, ou seja, os edifícios devem ser pensados numa lógica que contemple todas as fases do seu ciclo de vida.

a) Fase de projeto

Realmente importante nesta fase são as opções tomadas no que diz respeito ao desenvolvimento do projeto, tais como a escolha do local e das soluções construtivas a utilizar, os fornecedores, os materiais, as necessidades energéticas e de consumo de água, entre outras, cujas repercussões irão se refletir nas restantes fases do ciclo de vida do edifício (PINHEIRO, 2006).

Todos os aspectos que possam tornar a construção mais sustentável devem ser considerados e definidos nesta fase. Devem ser desenvolvidos esforços no sentido de aumentar a responsabilidade dos projetistas a uma reflexão na escolha materiais e soluções construtivas com requisitos de sustentabilidade e, ao mesmo tempo, promover uma maior interligação entre as diversas especialidades. 
Uma construção só pode ser considerada sustentável quando as três dimensões do desenvolvimento sustentável - ambiental, econômica e social são ponderadas durante a fase de projeto (REIS, 2015). A importância de considerar a sustentabilidade logo no início do desenvolvimento do projeto atende à necessidade de encontrar soluções de longo prazo que garantam um equilíbrio entre essas três dimensões. Vários autores reconhecem a importância da fase de projeto para se atingirem níveis elevados de sustentabilidade nos edifícios. Durante este estágio são definidos a maioria dos materiais e métodos de construção, bem como são determinadas as questões relacionadas com a funcionalidade e qualidade do edifício (REKOLA et al., 2012).

Segundo Mateus (2009), as decisões tomadas na fase de concepção, são as que mais determinam os custos do ciclo de vida, o consumo de energia, a qualidade do ar no interior, o conforto dos utilizadores e o potencial de reciclagem e de reutilização dos resíduos de construção e demolição.

b) Fase de construção

Nessa fase, existe um número significativo de impactos diretos ao meio ambiente, dentre eles destacam-se as alterações provocadas pela intervenção na envolvente (por exemplo, impermeabilização do solo, afetação aos ecossistemas, alteração na paisagem, incômodo às comunidades locais, poluição sonora), consumo de energia e de meios de transporte (que por sua vez consomem combustíveis e aumentam a poluição atmosférica), consumo de água e produção de efluentes que necessitam de tratamento, utilização de materiais perigosos que na falta de um controle eficaz pode induzir graves contaminações no solo, entre muitos outros (PINHEIRO, 2006).

No que diz respeito aos impactos indiretos, destacam-se a extração de matérias primas que serão posteriormente utilizadas nos materiais de construção definidos pelo projeto, a transformação ou produção desses mesmos materiais (incluindo transporte até ao local onde irão ser manufaturados), bem como os resíduos e emissões produzidas (REIS, 2015). 
Deve ser enfatizado que nesta fase, mesmo que por um curto período de tempo, os impactos causados são muito significativos e geram alterações relevantes sobre a paisagem e os ecossistemas.

c) Fase de utilização

A fase de operação compreende o período de tempo que decorre entre a recepção da obra e o final do seu período de vida, incluindo também possíveis obras de manutenção e renovações pontuais (PINHEIRO, 2006). Existem diversos impactos diretos relacionados do uso do edifício, dentre eles destacam-se o consumo de energia, de água, de materiais, a geração de resíduos, de efluentes e de emissões de gases para a atmosfera.

No setor da construção, de $10 \%$ a $20 \%$ da energia é consumida durante as fases de produção de materiais, transporte, construção, manutenção e demolição, enquanto que cerca de $80 \%$ se consume na fase de utilização do edifício (UNEP13, 2009 apud PUNHAGUI, 2014. p. 4). Durante esta fase, grande parte do desempenho energético dependerá do comportamento do consumidor e de como ele utilizará os recursos energéticos disponíveis e tecnologias empregadas na edificação (PUNHAGUI, 2014).

De acordo com Tavares (2006) entre $64 \%$ e $72 \%$ do consumo de energia ocorre na fase de utilização do edifício, sendo que entre $20 \%$ a $24 \%$ refere-se à utilização de eletricidade para o funcionamento de equipamentos. Levando em conta o fato de que o consumidor não tem controle sobre a energia incorporada aos edifícios nas fases anteriores à construção, como a extração e fabricação de materiais, ele apenas pode, quando possível, escolher os materiais que têm um melhor desempenho.

Outro fator relevante é que a estimativa, em nível mundial, é de que $25 \%$ das emissões de $\mathrm{CO}_{2}$ se concentram na fase de utilização dos edifícios, tanto no que diz respeito às emissões diretas como a queima de combustíveis fósseis para fins de condicionamento ambiental, aquecimento de água e

13 UNEP - United Nations Environment Programme e SBCI - Sustainable Buildings \& Climate Initiative, Buildings and Climate Change. Summary for Decision-Makers. UNEP, 2009. 
cozinha quanto as indiretas, com emissões associadas à eletricidade. (LEVINE et al. ${ }^{14}, 2007$ apud AGOPYAN e JOHN, 2011 p. 47) e (PRICE et al. ${ }^{15}, 2006$ apud AGOPYAN e JOHN, 2011 p. 47)

d) Fase de Renovação/Demolição

A fase de renovação ou demolição contempla uma possível renovação de grandes dimensões do edifício, que o capacite para uma nova utilização, mas também pode representar o possível desmantelamento, desmontagem ou demolição do edifício, concluindo assim o seu período de atividade.

Os principais impactos causados nessa etapa são o consumo de materiais (embora de forma mais reduzida que na construção) e de energia, emissões atmosféricas, o ruído produzido e, assumindo especial destaque nesta fase, a produção de resíduos de construção e demolição (RCD). Os resíduos da construção civil podem ser definidos, segundo a NBR 15113 / $2004^{16}$ como sendo resíduos provenientes de construções, reformas, reparos e demolições de obras de construção civil, e os resultantes da preparação e da escavação de terrenos, tais como tijolos, blocos cerâmicos, concreto em geral, solos, rochas, metais, resinas, colas, tintas, madeiras e compensados, forros, argamassa, gesso, telhas, pavimento asfáltico, vidros, plásticos, tubulações, fiação elétrica etc., comumente chamados de entulhos de obras, caliça ou metralha.

Durante esta fase, a reutilização e reciclagem de materiais toma particular relevância, permitindo desta forma, a redução de extração de materiais novos e a produção de resíduos (REIS, 2015).

\footnotetext{
14 LEVINE, M., URGE-VORSATZ, D., BLOK, K., GENG, L., HARVEY, D., LANG, S., LEVERMORE, G., MONGAMELI MEHLWANA, A., MIRASGEDIS, S., NOVIKOVA, A., RILLING, J., YOSHINO, H. Residential and commercial buildings. In: Climate change 2007: Mitigation Contribution of Working Group III to the Fourth Assessment Report of the Intergovernmental Panel on Climate Change 60, 2007.

${ }^{15}$ PRICE, L. et al. Sectoral trends in global energy use and green-house gas emissions. Berkeley: LBNL, 2006.

${ }^{16}$ A NBR 15113/2004 fixa os requisitos mínimos exigíveis para projeto, implantação e operação de aterros de resíduos sólidos da construção civil classe $A$ e de resíduos inertes. Visa a reservação de materiais de forma segregada, possibilitando o uso futuro ou, ainda, a disposição destes materiais, com vistas à futura utilização da área, além de visar também a proteção das coleções hídricas superficiais ou subterrâneas próximas, das condições de trabalho dos operadores dessas instalações e da qualidade de vida das populações vizinhas (NBR $15113 / 2004)$
} 
O Brasil possui uma legislação específica para regular os resíduos de construção e demolição, destacando-se a Lei Nacional sobre Resíduos Sólidos (Lei n. 12.105, 2012), a resolução do CONAMA 307 e a norma brasileira de resíduos sólidos da construção civil e resíduos inertes - aterros - diretrizes para projeto, implantação e operação (NBR 15113 / 2004).

Nesse sentido a arquitetura tem papel fundamental para a redução da degradação ambiental, sendo que a denominação de arquitetura sustentável está intimamente ligada àquela que respeita a natureza dos materiais, extraindo deles seu melhor comportamento, contribuindo diretamente para um melhor desempenho das edificações. Tal arquitetura propõe o uso da simplicidade, com baixo custo energético para a obtenção de resultados práticos, pautada em fundamentos teóricocientíficos, tornando os projetos mais abrangentes.

De acordo com Kronka (2001), pode-se identificar quatro variáveis básicas nesta nova arquitetura: a sustentabilidade, a cidadania, o meio ambiente e a tecnologia.

Com a sustentabilidade há uma garantia de preservação do capital natural. Esta pode ser vista como uma tentativa de ordenar o uso do território de modo a promover uma interação entre o ambiente físico e o crescimento econômico, reconhecendo os limites naturais e estruturais, englobando aspectos sociais, políticos econômicos, espaciais, ecológicos e culturais (BURSZTYN et al.,1994). Todos estes aspectos devem ser respeitados para garantir a sustentabilidade geral do sistema (KRONKA, 2001).

Os aspectos da cidadania garantem uma participação da comunidade nos projetos, devendo o arquiteto, projetar sob este novo conceito, levando em consideração que atualmente observa-se a existência de muitos "consumidores" e em menor número os "cidadãos" (KRONKA, 2001).

O meio ambiente também passa a ter um papel fundamental nas diretrizes dos projetos, pois a utilização dos seus recursos de forma racional, respeitando aspectos de sustentabilidade de todo o sistema, garante a manutenção de vida para as gerações futuras (LYLE ${ }^{17}, 1994$ apud KRONKA, 2001. p. 68). É importante

\footnotetext{
17 LYLE, J. T. Regenerative Design for Sustainable Development. Poly!echnic University, Pomona; publicação John Wiley \& Sons. Califórnia, Estados Unidos da América. 1994.
} 
salientar que não é apenas a preservação do meio ambiente que garante esta sobrevivência, pois existem locais que devem ser preservados e outros que podem e devem ser explorados de maneira racional. Existem áreas com qualidades produtivas e outras com qualidades de proteção (ARCHITECTURAL DESIGN ${ }^{18}$, 1997 apud KRONKA, 2001. p. 68).

A tecnologia é o elemento que deve servir de elo de ligação entre as três variáveis anteriores, garantindo assim, a existência e interrelação das mesmas. Segundo Bursztyn et al. (1994) ainda não existe uma ciência sobre as questões de sustentabilidade global e local, não se tendo uma definição clara deste conceito nem soluções para os problemas apresentados em todas as escalas. A partir da implantação de projetos com elementos que "tentem" garantir a sustentabilidade é que poderemos avaliar a sua eficácia, suas falhas e termos insumos para os projetos subsequentes.

A verdadeira arquitetura sustentável não se preocupa somente com a utilização da vegetação, conservação de energia e minimização da poluição. Reconhece sim a sua importância em todo um contexto onde muitas outras variáveis estão inseridas e se relacionam tanto em âmbito local como global (PROCESS ${ }^{19}$, 1991 apud KRONKA, 2001. p. 68), indo muito além das relações entre homemambiente construído, aspectos de conforto térmico, lumínico, acústico e ergonômico (LYLE, 1994), como por exemplo as relações culturais, econômicas, políticas e sociais. Segundo Silva e Shimbo (2001), essa abordagem poderia se ampliar para outros aspectos, tais como: institucionais, científicos, tecnológicos e geográficos.

Como a ameaça de um futuro caos no meio ambiente tem se tornado cada vez mais evidente, as empresas privadas e públicas devem unir produção com ferramentas de gestão ambiental. Para não se tornar muito dispendioso, a gestão ambiental tem que ser vista como forma do processo e como ferramenta de melhorias de produtividade (COMELATO; VARASQUIM, 2012).

Atualmente o desenvolvimento sustentável já é uma realidade econômica na indústria da construção civil, com mercados em forte crescimento e uma tendência no aumento da demanda por materiais e produtos ecologicamente adequados aos novos paradigmas da arquitetura. As grandes empresas tomaram consciência de

\footnotetext{
${ }^{18}$ ARCHITECTURAL DESIGN -AD. The Architecture of Ecology, Londres, Inglaterra. 1997.

19 PROCESS ARCHITECTURE. Passive and Low Energy Architecture. no 98. Tokyo, Japão, 1991.
} 
que a aplicação das exigências da sustentabilidade as permitiu produzir mais eficazmente, reforçar sua imagem de marca e se diferenciar da competição.

O desenvolvimento sustentado pode ser alcançado pelo setor florestal não só pela produção direta de madeira e de matéria-prima na fabricação de produtos dela derivadas, mas pela geração de outros bens, sempre primando pela manutenção do equilíbrio ecológico. Segundo Oliveira (1997), a atividade florestal com o emprego de métodos racionais de exploração, poderá conjugar a expansão econômica à conservação da qualidade de vida.

Segundo Pfeil (2003), a madeira é provavelmente o material de construção mais antigo, dado a sua disponibilidade na natureza e sua relativa facilidade de manuseio, sendo que, quando comparada a outros materiais de construção utilizados na atualidade, ela apresenta uma excelente relação resistência/peso, além de outras características favoráveis ao uso em construção como, por exemplo, a facilidade na fabricação de diversos produtos industrializados e bom isolamento térmico.

Ainda segundo o autor, a madeira é um material de construção empregado pelo homem desde épocas pré-históricas. Mesmo até o século XIX, as mais importantes obras de engenharia eram construídas em pedra ou madeira, combinando-se frequentemente os dois materiais. Mas apesar do longo período de utilização, só na primeira metade do século XX é que foram estabelecidas teorias, processo de cálculo estrutural e técnicas construtivas aplicadas a estruturas de madeira. Atualmente, a utilização da madeira como material de construção economicamente competitivo e aceitável em termos ecológicos se baseia nas técnicas mais modernas de reflorestamento conciliadas ao desenvolvimento de produtos industrializados de madeira com elevada qualidade.

\footnotetext{
"O uso milenar da madeira determinou um número de conhecimentos que a humanidade consolidou boa parte das informações fundamentais sobre a utilização e manejo já no final da Idade Média. A novidade introduzida pelos séculos se dá após a $2^{a}$ Grande Guerra, em países desenvolvidos, com 0 desenvolvimento de uma tecnologia apropriada à utilização em escalas das madeiras de florestas nativas, de crescimento lento e baixa economicidade, e sobre as quais se têm trabalhado ao longo dos séculos" (CRUZEIRO, 1998. p. 70).
} 
É justamente em países desenvolvidos que a madeira é largamente utilizada na construção civil, onde processos industriais consolidados garantem qualidade tanto à matéria-prima quanto ao produto final. Nestes países, construções em madeira são predominantes em habitações isoladas, podendo ser vistas em edificações de maior porte.

Segundo Gauzin-Muller (2011), o incremento do uso da madeira como material de construção é de extrema importância e para a maioria dos governos europeus, responsável diretamente para o combate ao efeito estufa. Com o intuito de concretizar os compromissos assumidos durante a Conferência das Nações Unidas sobre Meio Ambiente e Desenvolvimento no Rio de Janeiro (RIO 92), vários campos de ação foram definidos durante a Conferência Ministerial para a Proteção das Florestas na Europa, tais como, gestão sustentável do patrimônio florestal; redução dos desperdícios na exploração madeireira; aproveitamento energético da biomassa a fim de economizar os combustíveis fósseis e; desenvolvimento do uso da madeira na construção.

Uma das variáveis utilizadas no manejo florestal é exatamente a biomassa das florestas, fator que nos permite compreender a produção primária de um ecossistema e avaliar o potencial de uma floresta para a produção de energia, além de ser um elemento também importante no entendimento dos processos envolvidos nas mudanças climáticas globais, pois pode-se considerar que aproximadamente $50 \%$ da madeira seca é carbono (C), sendo que o estoque do mesmo é utilizado na estimativa da quantidade de $\mathrm{CO}_{2}$ que é liberada para a atmosfera durante $\mathrm{o}$ processo de queima da biomassa (SFB, 2013). Segundo o Centro Nacional para o Desenvolvimento da Madeira da França (CNDB), 1,0 tonelada de madeira utilizada na construção representa cerca de 1,6 toneladas de $\mathrm{CO}_{2}$ a menos na atmosfera, pois ao ser utilizada a madeira retém seu estoque de carbono absorvido durante sua vida, ao contrário de sua queima ou decomposição natural, que promovem o retorno do gás carbônico para a natureza. ${ }^{20}$

\footnotetext{
20 O seqüestro de carbono um foi conceito definido pela Conferência de Kyoto, em 1997, cuja finalidade é de contenção e reversão do acúmulo de $\mathrm{CO}_{2}$ na atmosfera, objetivando a diminuição do efeito estufa. Pode ser definido como um processo que evita a permanência de dióxido de carbono na atmosfera terrestre através de um processo natural chamado fotossíntese, que promove a captura e estocagem do carbono nos organismos que a realizam, além do lançamento de oxigênio na atmosfera.Um dos fatores mais relevantes para a emissão e aumento dos níveis de dióxido de carbono para a atmosfera é a queima de combustíveis fósseis, além de diferentes usos da terra, associados ao desmatamento e às queimadas, fatores que contribuem para o aquecimento global.
} 
Segundo Punhagui (2014) alguns estudos internacionais, realizados sob diferentes abordagens e métodos de análise no campo da construção civil indicam, em geral, que a madeira é um recurso com menor intensidade de energia e emissão de carbono do que outros materiais, como aço ou concreto. Um estudo estimou que cerca de duas toneladas de carbono deixam de ser emitidas para cada tonelada de madeira usada no lugar de outro material de construção (SATHRE; O'CONNOR, 2010).

A madeira é um material renovável que absorve o dióxido de carbono da atmosfera, contribuindo para a redução de gases de efeito estufa, devendo, portanto, ser utilizada para fins de longo prazo, para que o carbono absorvido continue armazenado no material até o fim do seu ciclo de vida. O carbono armazenado é consideravelmente maior quando comparado com outros materiais (BUCHANAN; LEVINE²1, 1999 apud PUNHAGUI, 2014. p. 6), tendo uma média de $490 \mathrm{~kg}$ de carbono por tonelada de madeira seca (IPCC, 1997). A madeira é versátil e há muitas espécies com diferentes qualidades que podem ser utilizados para usos diversos, como combustível, mobiliário, papel, materiais de construção, etc. Entre $50 \%$ e $56 \%$ de toda a madeira produzida no mundo é destinada para o setor da construção (UN²2, 2009 e MATTHEWS ${ }^{23}, 2000$ apud PUNHAGUI, 2014. p. 6).

A escala das remoções de $\mathrm{CO}_{2}$ e a capacidade de manutenção por prazos longos fazem com que a componente florestal tenha um potencial de mitigação bastante elevado, logo a manutenção e ampliação de estoques podem ter um papel relevante para o equilíbrio do balanço de emissões do setor produtivo brasileiro como um todo.

Os produtos de base florestal podem contribuir não apenas para a manutenção ou aumento de estoques de carbono nas áreas de plantio, mas também para evitar as potenciais emissões associadas ao uso de produtos oriundos de matérias-primas fósseis ou não renováveis em diferentes etapas da cadeia produtiva, o que traz inúmeros benefícios às atuais condições climáticas.

\footnotetext{
21 BUCHANAN A. H., LEVINE, S. B. Wood-based building materials and atmospheric carbon emissions, Environmental Science \& Policy, vol. 2, no 6, p. 427-437, dez. 1999.

22 UN - United Nations, Vital forest graphics. Nairobi Kenya: UNEP, 2009.

${ }^{23}$ MATTHEWS, E. From Forests to Floorboards: Trends in Industrial Roundwood Production and Consumption. WRI, out-2000.
} 
Pode-se destacar, portanto, que existem dois tipos de potenciais benefícios climáticos diretamente associados à produção de florestas: os estoques de carbono nas áreas de plantio e as potenciais emissões evitadas por meio do uso de produtos florestais bem manejados ao invés de produtos de base fóssil ou não renovável, em diferentes etapas da cadeia produtiva.

Além do que tange ao estoque de carbono, a Associação Brasileira de Produtores de Florestas Plantadas (ABRAF, 2013), destaca que em 2012 a participação da biomassa na geração de energia elétrica no Brasil representou 7\%, imediatamente atrás da matriz hidráulica, que representou 82\%, conforme Gráfico 1 . Entre as principais biomassas utilizadas está a de base florestal, que representa atualmente $15,8 \%$ da geração de energia elétrica. Contudo, o potencial de geração de energia a partir de resíduos florestais é significativamente maior, pois anualmente são gerados aproximadamente 41 milhões de toneladas de resíduos madeireiros provindos da indústria de processamento de madeira e da colheita florestal, capazes de gerar energia equivalente a 1,7 GW/ano.

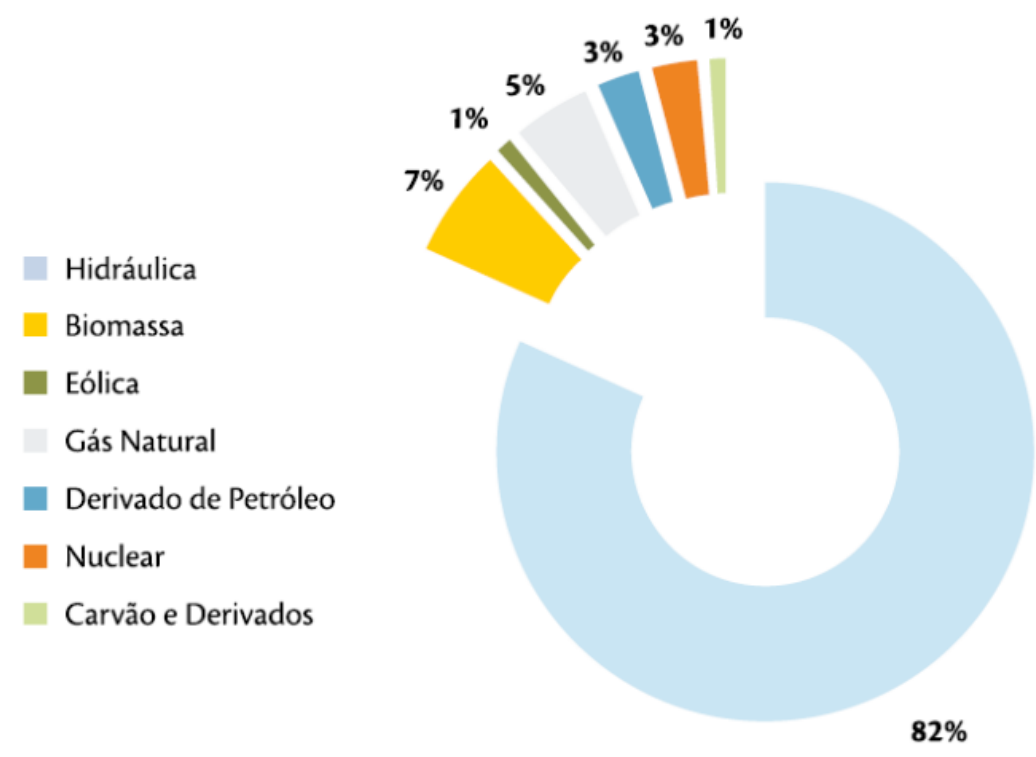

Gráfico 1 - Distribuição da matriz energética brasileira

Fonte: ABRAF, 2013

Dentre as ações do governo brasileiro direcionadas à diversificação da matriz energética nacional destaca-se projeto de lei 3.529/2012, datado de 03 de maio de 2012, que estabelece em seu Art. 1ํ: "Esta lei estabelece incentivo à produção de energia elétrica a partir da biomassa; institui a política nacional de cogeração de energia elétrica a partir da biomassa; e estabelece a obrigatoriedade de contratação 
de energia elétrica produzida a partir dessa fonte", considerando como biomassa as fontes renováveis provenientes de resíduos urbanos, agrícolas e florestais.

É de extrema importância ressaltar o caráter complementar dessa energia frente ao sistema hidrelétrico, podendo contribuir na geração de energia no período de menor índice pluviométrico na redução das emissões de gases geradores de efeito estufa, ao substituir outras fontes de origem fóssil.

Outro fator a ser considerado para utilização de materiais de base florestal está pautado na quantidade de energia necessária para a produção, transporte e fabricação de materiais atualmente destinados à construção civil, como o aço, o concreto e o alumínio, conforme apresentado na Tabela 3.

Tabela 3 - Energia necessária em kWh para a produção de $1 \mathrm{~m}^{3}$ de componentes construtivos

\begin{tabular}{c|c}
\hline Material & Consumo Energético (kWh) \\
\hline Madeira & 8 a 30 \\
\hline Concreto & 150 a 200 \\
\hline Peças de construção em aço & 500 a 600 \\
\hline Peças de construção em alumínio & 800 \\
\hline
\end{tabular}

Fonte: CRUZEIRO (1998)

Pode-se compreender porque a madeira é amplamente utilizada em países desenvolvidos, como Alemanha, Reino Unido, Canadá, França, Rússia e Japão (PUNHAGUI, 2014), mesmo sendo eles detentores das técnicas mais avançadas no uso de materiais como o aço, pois o custo energético da produção de componentes de madeira é praticamente nulo, quando comparado aos outros materiais citados ${ }^{24}$.

\footnotetext{
24 Em PUNHAGUI (2014) são apresentadas algumas conclusões de estudos de alguns autores: BUCHANAN e LEVINE (1999) concluíram que os edifícios de madeira requerem menos energia no processamento e produzem emissões de carbono mais baixas do que edifícios feitos de outros materiais, como tijolo, alumínio, aço ou concreto; BORJESSON e GUSTAVSSON (2000) concluíram que a energia consumida na produção de materiais em estruturas de concreto é maior que para a madeira, enquanto as emissões líquidas de gases de efeito estufa para materiais de madeira depende do seus destinos finais; GUSTAVSSON et. al. (2006) concluíram que, na Suécia e na Finlândia, os edifícios com estrutura de madeira requerem menos energia e emitem menos $\mathrm{CO}_{2}$ do que construções com estrutura de concreto; GERILLA et. al (2007) concluíram que a construção de madeira apresenta impacto ambiental menor do que o concreto; GUSTAVSSON e SATHRE (2006) concluíram que o uso de madeira (integrado com o aproveitamento de resíduos para sistemas de energia) ao invés do concreto seria um meio eficaz de redução do uso de combustíveis fósseis e as emissões líquidas de $\mathrm{CO}_{2}$ para a atmosfera; os mesmos autores, em 2009, concluíram que a fabricação de materiais utilizados em um edifício de madeira tem menos consumo primário de energia e emite menos carbono do que a fabricação de materiais utilizados em um edifício de concreto; XIMENES e GRANT (2013) concluíram que a otimização da utilização de produtos de madeira no projeto de casas na Austrália pode salvar as emissões de gases de efeito estufa.
} 
Claro que a utilização de soluções construtivas que empreguem materiais como o concreto, o aço e o alumínio, não pode e não deve ser descartada, pois mesmo à custa de um maior consumo de energia, emissões de $\mathrm{CO}_{2}$ e energia incorporada, tais materiais são imprescindíveis em certas ocasiões, devendo ser utilizadas soluções que os empreguem de maneira adequada segundo suas características; além do fato de que a diminuição de sua utilização pode gerar impactos sociais e econômicos. O que se deve levar em consideração é uma análise conjunta de seu desempenho e vida útil para a aplicação para o qual estão sendo destinados bem como a utilização destes materiais de maneira mais coerente e condizente com a realidade em que vivemos, enfatizando os fatores ambientais e a sustentabilidade.

Em relação ao Brasil, um dos fatores que contribuíram para a não utilização da madeira como material construtivo foi sua própria colonização, que por herança dos portugueses, passou a construir com pedra e/ou terra (adobe e taipa), resultando em uma interpretação equivocada dos materiais e da linguagem decorrente de seu uso. O modelo dominante atual e quase hegemônico das construções brasileiras é a utilização do concreto armado e alvenarias de tijolos cerâmicos e/ou de concreto.

Países da Europa e os Estados Unidos modernizaram seu parque industrial após a $2^{\text {a }}$ Guerra Mundial, principalmente no que diz respeito a sistemas préfabricados em madeira devido a fatores como demanda habitacional e necessidade de racionalização de processos construtivos, ao contrário do Brasil que, devido mais a questões culturais e políticas do que tecnológicas, não utiliza tais sistemas, limitando-se ao uso da madeira em subsistemas de cobertura na construção civil, sendo este setor o que menos consome madeira proveniente das florestas plantadas. (VALLE, et al., 2012).

A cadeia produtiva do setor brasileiro de base florestal associado às florestas plantadas desempenham importantes funções sociais, econômicas e ambientais, prestam serviços ambientais essenciais, como a conservação dos recursos hídricos, a conservação da biodiversidade e a estabilidade climática, além de ofertarem uma variedade de bens caracterizados pela grande diversidade de produtos, compreendendo a produção, a colheita e o transporte de madeira, além da obtenção dos produtos finais nos segmentos industriais de papel e celulose, painéis de 
madeira industrializada, madeira processada mecanicamente, siderurgia a carvão vegetal e biomassa, entre outros.

A noção de construção sustentável deve estar presente em todo o ciclo de vida dos empreendimentos, que podem ser concebidos e planejados para que suprimam menores áreas de vegetação, otimizem o uso de materiais, demandem menos energia e água durante sua fase de construção e operação minimizando a geração e emissões de resíduos; sejam duráveis, flexíveis e passíveis de requalificação; tenham menores custos de manutenção, opções para demolição e possam ser amplamente reaproveitados e reciclados no fim de seu ciclo de vida. 


\section{A MADEIRA COMO MATERIAL SUSTENTÁVEL}

No Brasil verifica-se uma situação florestal favorável no que se refere à alta capacidade de produção de madeira proveniente de atividades silviculturais ${ }^{25}$ e de manejo florestal certificado. O elevado potencial de emprego da madeira como material de construção, somado ao conhecimento técnico e científico e à qualificação dos profissionais do setor da construção civil e da cadeia produtiva da madeira, pode favorecer o desenvolvimento e a produção de forma sustentável de edificações em madeira, em particular de componentes estruturais pré-fabricados.

Nos últimos 30 anos, o Brasil desenvolveu um sistema de manejo florestal para a produção de madeira em florestas primárias da Amazônia, que concilia o uso e a conservação dos recursos florestais. Paralelamente, o país desenvolveu um marco regulatório adequado, aprimorado ao longo de anos por um conjunto de normas que inclui a elaboração de planos de manejo florestal sustentável, planos operacionais anuais e monitoramento do manejo florestal por meio de vistorias técnicas.

O manejo florestal sustentável pode ser caracterizado como a administração da floresta para a obtenção de benefícios econômicos, sociais e ambientais, respeitando-se os mecanismos de sustentação do ecossistema objeto do manejo e considerando-se, cumulativa ou alternativamente, a utilização de múltiplas espécies madeireiras, de múltiplos produtos e subprodutos não madeireiros, bem como de outros bens e serviços de natureza florestal (SFB, 2010).

A Food and Agriculture Organization of The United Nations (FAO) ${ }^{26}$ define floresta como sendo:

\footnotetext{
25 Segundo dados de 1984 do Instituto Brasileiro de Geografia e Estatística (IBGE), a atividade de silvicultura é a "cultura de essências florestais e extração de produtos dessas essências (madeira, lenha, cascas, folhas, gomas vegetais, etc.)". O reflorestamento é, por sua vez, a atividade de plantio de essências florestais e, portanto, é parte da atividade de silvicultura que inclui a extração de produtos de árvores plantadas (BACHA, 1993 apud RIBEIRO, 2013. p. 30).
}

BACHA, C. J. C., A dinâmica do desmatamento e do reflorestamento no Brasil. Tese de Livre Docência, ESALQ/USP, Piracicaba, 1993

26 Sediada em Roma, Itália e criada em 16 de outubro de 1945, a Organização das Nações Unidas para Alimentação e Agricultura (FAO) atua como um fórum neutro, onde todos os países, desenvolvidos e em desenvolvimento, se reúnem em igualdade para negociar acordos, debater políticas e impulsionar iniciativas estratégicas. Atualmente a FAO tem 191 países membros, mais a Comunidade Européia. A FAO trabalha no combate à fome e à pobreza, promove o desenvolvimento agrícola, a melhoria da nutrição, a busca da segurança alimentar e o acesso de todas as pessoas, em todos os momentos, aos alimentos necessários para uma vida saudável. Reforça a agricultura e o desenvolvimento sustentável, como estratégia a longo prazo, para 
[...]uma área medindo mais de 0,5 ha com árvores maiores que $5 \mathrm{~m}$ de altura e cobertura de copa superior a 10\%, ou árvores capazes de alcançar estes parâmetros in situ. Isso não inclui terra que está predominantemente sob uso agrícola ou urbano".

Já o conceito de plantios florestais é definido como "florestas formadas por espécies nativas ou exóticas, introduzidas pelo homem por meio do plantio de mudas ou por semeadura".

A floresta nativa brasileira, localizada na região Amazônica, possui um potencial de extração entre 18 e $72 \mathrm{~m}^{3} / \mathrm{ha}$ (uma média de $35 \mathrm{~m} 3 / \mathrm{ha}$ ) (CAMPOS, 2012). Em estudos realizados por Monteiro et al. (2011) publicados pelo Instituto do Homem e Meio Ambiente da Amazônia $\left(\mathrm{IMAZON}^{27}\right.$ ) no Boletim Transparência Manejo Florestal do Estado do Pará, foi constatado que entre agosto de 2008 a julho de 2009 e agosto de 2009 a julho de 2010, houve uma redução de 16\% na exploração não autorizada (15.444 hectares) e um aumento de 33\% (10.400 hectares) na exploração autorizada, sendo que a exploração madeireira sob manejo florestal aumentou entre os períodos de estudo, verificando-se 24.370 hectares com exploração de boa qualidade, 16.915 hectares com qualidade intermediária e 12.021 hectares com qualidade baixa (exploração predatória).

Foram detectados 120.512 hectares de florestas exploradas dos quais 78.941 hectares (65\%) não tinham autorização e 41.571 hectares (35\%) foram autorizados para manejo florestal. Entretanto, ao compararmos as áreas exploradas no período compreendido entre agosto de 2008 a julho de 2009, com o período de agosto de 2009 a julho de 2010, observa-se positivamente uma redução de $16 \%$ da exploração não autorizada e um aumento de $38 \%$ da exploração autorizada (MONTEIRO et al., 2011).

Comparando a qualidade da exploração florestal entre os dois períodos analisados, observou-se um aumento positivo da área com exploração de boa

aumentar a produção e o acesso de todos aos alimentos, ao mesmo tempo em que preserva os recursos naturais. Disponível em <https://www.fao.org.br/quemSomos.asp >. Acesso em 16 jul. 2015.

\footnotetext{
${ }^{27} \mathrm{O}$ Imazon é um instituto de pesquisa cuja missão é promover o desenvolvimento sustentável na Amazônia por meio de estudos, apoio à formulação de políticas públicas, disseminação ampla de informações e formação profissional. O Instituto foi fundado em 1990, e sua sede fica em Belém, no Pará. É uma associação sem fins lucrativos e qualificada pelo Ministério da Justiça do Brasil como Organização da Sociedade Civil de Interesse Público (Oscip).

O instituto desenvolve pesquisas que incluem diagnóstico socioeconômico na Amazônia; desenvolvimento de métodos para avaliação e monitoramento desses usos; realização de projetos demonstrativos; análise de políticas públicas de uso do solo; e elaboração de cenários e modelos de desenvolvimento sustentável para essas atividades econômicas.

Disponível em: <http://imazon.org.br/institucional/quem-somos/>. Acesso em 16 jul. 2015.
} 
qualidade e de qualidade intermediária e aumento negativo da área com exploração de qualidade baixa (exploração predatória), sendo que o aumento mais expressivo foi observado na exploração de boa qualidade (24 mil hectares).

Os dados indicam a viabilidade de aplicação da madeira serrada proveniente de áreas de manejo florestal certificado na produção, em escala industrial, de sistemas construtivos pré-fabricados. Atualmente, verifica-se uma tendência no aumento de oferta de madeira serrada certificada, visto que o número de certificados apresentou um crescimento considerável na última década. Segundo dados do Instituto de Manejo e Certificação Florestal e Agrícola ${ }^{28}$ (IMAFLORA)/SmartWood, no ano de 2009 foram totalizados 107 empreendimentos certificados com verificação de práticas socioambientais, correspondendo uma área total de 2,88 milhões de hectares. No país, 14 estados possuem empreendimentos certificados em 4 biomas distintos, que são: Mata Atlântica, Amazônia, Caatinga e Cerrado.

Um fator a ser considerado é o fato de que, para atingir os principais mercados consumidores (São Paulo, Paraná e Minas Gerais), a madeira nativa é transportada por uma distância aproximada de $4.500 \mathrm{~km}$ por via rodoviária. Essa etapa do processo produtivo pode reduzir o estoque líquido de carbono devido à queima de combustíveis fósseis, o que significa haver uma distância-limite a partir da qual as emissões de $\mathrm{CO}_{2}$ do transporte ultrapassam a quantidade de carbono estocada na madeira (GUSTAVSSON; ERIKSSON; SATHRE ${ }^{29}, 2011$ apud CAMPOS; PUNHAGUI; JOHN, 2011. p. 158).

É importante ressaltar que a variação de consumo de combustível pode ser, de fato, observada na prática devido a fatores como tipo de veículo, sua tecnologia, tempo de vida e manutenção; qualidade do combustível; temperatura de operação;

\footnotetext{
28 O Instituto de Manejo e Certificação Florestal e Agrícola - Imaflora - é uma associação civil sem fins lucrativos, fundada em Piracicaba, no interior de São Paulo, em 1995. Nasceu sob a premissa de que a melhor forma de conservar as florestas tropicais é dar a elas uma destinação econômica, associada a boas práticas de manejo e a uma gestão responsável dos recursos naturais. Dessa perspectiva, o Imaflora acredita que a certificação socioambiental é uma das ferramentas que respondem a parte desse desafio, com forte poder indutor do desenvolvimento local, sustentável, nos setores florestal e agrícola. Da mesma maneira, o Instituto busca influenciar as cadeias produtivas dos produtos de origem florestal e agrícola; colaborar para a elaboração e implementação de políticas de interesse público e, finalmente, fazer, de fato, a diferença nas regiões em que atua, criando ali modelos de uso da terra e de desenvolvimento sustentável que possam ser reproduzidos em outros municípios, regiões ou biomas do País. Disponível em <http://www.imaflora.org/imaflora.php >. Acesso em 15 jul. 2015.
}

29 GUSTAVSSON, L.; ERIKSSON, L.; SATHRE, R. Costs and CO2 Benefits of Recovering, Refining and Transporting Logging Residues for Fossil Fuel Replacement. Applied Energy, v. 88, n. 1, p. 192-197, 2011. 
capacidade de carga do veículo; peso da carga transportada; distância percorrida; velocidade média do percurso; qualidade das vias e infraestrutura; condições de deslocamento; fluxo e congestionamento do sistema; topografia do percurso; condições climáticas no trajeto; hábitos e comportamento do motorista durante a condução; entre outros aspectos não menos importantes. (KAMAKATÉ; SCHIPPER ${ }^{30}$, 2009 e RUZZENENTI; BASOSI ${ }^{31}, 2009$ apud CAMPOS; PUNHAGUI; JOHN, 2011. p. 161).

É possível quantificar a emissão por litro de diesel como sendo $2.604 \mathrm{~g}$ de $\mathrm{CO}_{2} / \mathrm{l}$ e o valor médio de emissão por tonelada-quilômetro como sendo $37,0 \mathrm{~g}$ de $\mathrm{CO}_{2} / \mathrm{t} . \mathrm{km}$, resultando o consumo médio aproximado de diesel por toneladaquilômetro como 0,014 l/t.km.. Essas emissões são diretas, ou seja, não incluem os processos de extração, produção e transporte do combustível (CAMPOS; PUNHAGUI; JOHN, 2011).

Tomando-se como exemplo o transporte de madeira com um caminhão carregado com 35 toneladas de madeira (PBTC $\sim 50 \mathrm{t}$ ), para cada $1.000 \mathrm{~km}$ percorridos, seriam totalizados 50.000 t.km, tendo como resultado a geração de $1850,0 \mathrm{~kg}$ de $\mathrm{CO}_{2}$.

Portando, levando-se em conta somente o gasto energético do transporte e emissões de $\mathrm{CO}_{2}$ para a atmosfera pode-se afirmar que faz sentido a utilização de madeira proveniente de florestas nativas somente em locais próximos à região Norte do país, ou até locais onde a comparação entre o balanço de estoque e as emissões de $\mathrm{CO}_{2}$ seja positiva.

Outro fator que deve ser analisado é a degradação causada na floresta nativa pela abertura de caminhos para o acesso de equipamentos pesados e os danos causados à vegetação nativa pelo arrasto das toras, pois devido à densidade da vegetação (entre 290 e $616 \mathrm{~m}^{3} / \mathrm{ha}$ (CAMPOS, 2012)), a biomassa acima do solo é destruída (entre $0,7 \mathrm{~m}^{3}$ e 6,25 $\mathrm{m}^{3}$ de biomassa por metro cúbico de tronco extraído (CAMPOS, 2012; JOHNS; BARRETO; UHL ${ }^{32}$, 1996; IMAZON, 2002;

\footnotetext{
30 KAMAKATÉ, F.; SCHIPPER, L. Trends in Truck Freight Energy Use and Carbon Emissions in Selected OECD Countries from 1973 to 2005. Energy Policy, v. 37, n. 10, p. 3743-3751, 2009.

31 RUZZENENTI, F.; BASOSI, R. Evaluation of the Energy Efficiency Evolution in the European Road Freight Transport Sector. Energy Policy, v. 37, n. 10, p. 4079-4085, 2009.

32 JOHNS, J. S., BARRETO, P., UHL C. Logging damage during planned and unplanned logging operations in the eastern Amazon, Forest Ecology and Management, vol. 89, no 1-3, p. 59-77, dez. 1996.
} 
MACPHERSON 33 et al., 2010, ASNER ${ }^{34}, 2005$ apud PUNHAGUI, 2014. p. 7)), reduzindo o carbono que estava armazenado na floresta e convertendo-o em emissões de carbono (PUNHAGUI, 2014).

O Ministério do Meio Ambiente estima que $69 \%$ da cobertura florestal brasileira tenha potencial produtivo. Em decorrência disso, o país desenvolveu uma estrutura produtiva complexa no setor florestal, incluindo as florestas plantadas especialmente com Pinus e Eucalyptus. Suas relações com produtores de equipamentos, insumos, projetos de engenharia e empresas de produtos florestais, conferem elevado potencial de emprego da madeira como material de construção, somado ao conhecimento técnico e científico, bem como a qualificação dos profissionais do setor da construção civil e da cadeia produtiva da madeira. Tal fato pode contribuir para o desenvolvimento e a produção de forma sustentável de edificações em madeira, em particular de componentes estruturais para habitação.

Dentro deste raciocínio, a utilização de madeiras provenientes de áreas plantadas torna-se uma alternativa mais sustentável, uma vez que seu ciclo de renovação é mais curto que o das madeiras nativas e as distâncias dos locais de plantio aos centros consumidores são menores, aproximadamente $2.000 \mathrm{~km}$.

A Tabela 4 apresenta as distâncias percorridas pela madeira nativa e plantada desde a floresta até o consumidor final.

Tabela 4 - Distâncias percorridas pela madeira nativa e plantada em km

\begin{tabular}{l|c|c}
\hline \multicolumn{1}{c|}{ Local } & Madeira Nativa & Madeira Plantada \\
\hline Interior da floresta & 8 & 5 \\
\hline Floresta-serraria & 74 & 33 \\
\hline Serraria-beneficiamento & 2451 & 1350 \\
\hline Para consumidor & 1975 & 672 \\
\hline Total & $\mathbf{4 5 0 8}$ & $\mathbf{2 0 6 0}$ \\
\hline
\end{tabular}

Fonte: PUNHAGUI (2016) (informação verbal) ${ }^{35}$

\footnotetext{
33 MACPHERSON, A. J., SCHULZE, M. D., CARTER, D. R., VIDAL, E. A Model for comparing reduced impact logging with conventional logging for an Eastern Amazonian Forest, Forest Ecology and Management, vol. 260, p. 2002-2011, nov. 2010.

${ }^{34}$ ASNER, G. P. Selective Logging in the Brazilian Amazon, Science, vol. 310, p. 480-482, out. 2005.

35 Informação fornecida por Punhagui no XV Encontro Brasileiro de Madeira e em Estruturas de Madeira, em 2016.
} 
Levando em consideração o valor médio de emissão de $\mathrm{CO}_{2}$ por toneladaquilômetro obtido anteriormente, $1850,0 \mathrm{~kg}$ de $\mathrm{CO}_{2}$, para a madeira nativa encontramos um valor aproximado de 8,34 te $\mathrm{CO}_{2}$ emitidos contra 3,81 t para a madeira plantada.

No intuito de otimizar o gasto energético no transporte de madeira oriunda de florestas plantadas, deve-se levar em consideração a umidade da madeira, fator que influi diretamente no seu peso, portanto é recomendado que seja realizado um processo de secagem da madeira próximo às áreas de extração, aumentando assim o volume de madeira transportada e consequentemente a eficiência energética do transporte.

A Figura 6 ilustra, de forma simplificada, o modelo da produção florestal, destacando seus principais produtos e serviços. 


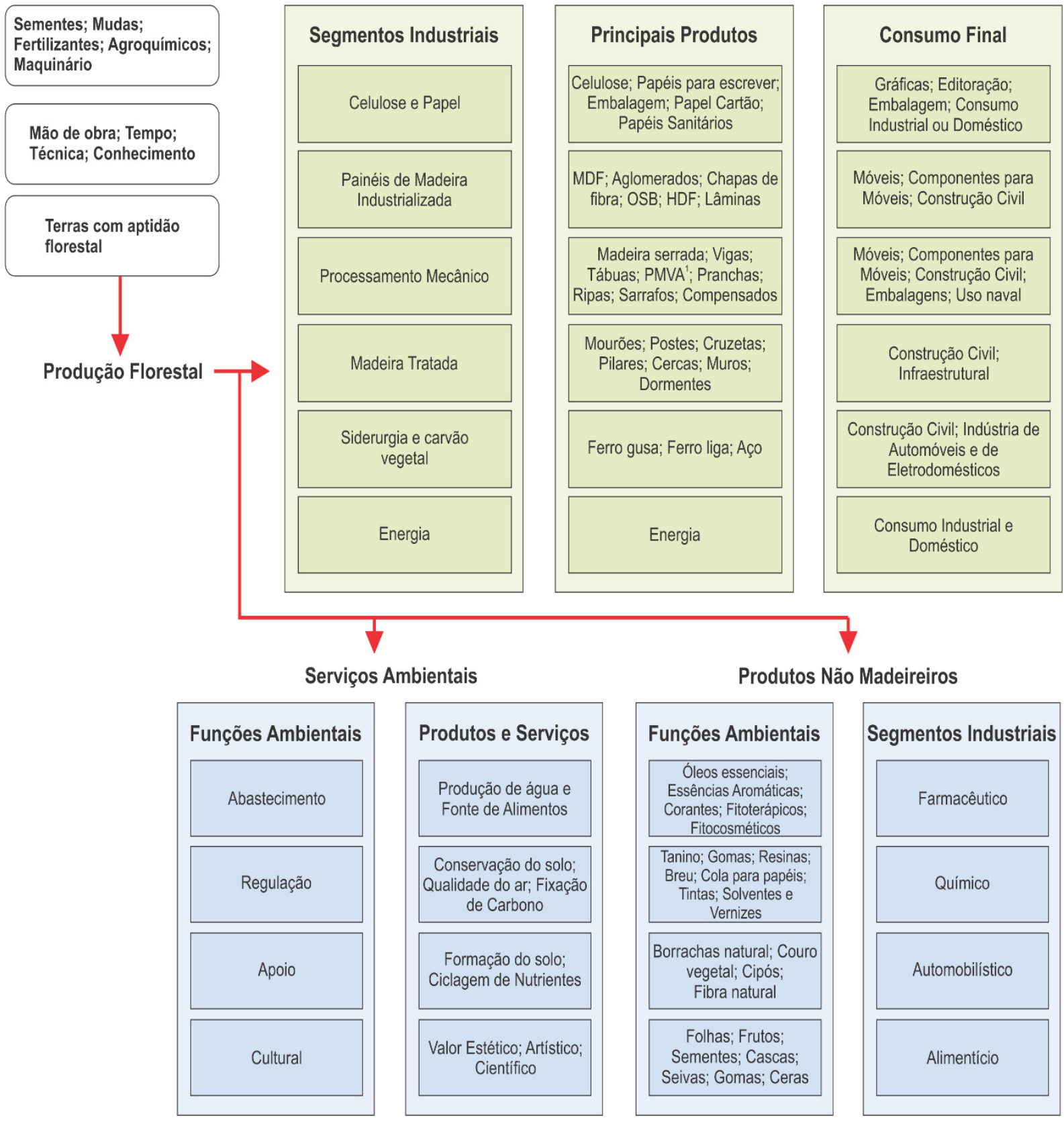

1 PMVA (Produtos de Maior Valor Agregado) - portas, janelas, molduras, pisos, dormentes, outros.

Figura 6 - Cadeia produtiva do setor florestal

Fonte: ABRAF (2013)

\subsection{A DISPONIBILIDADE DE MADEIRA NO BRASIL}

O setor madeireiro fornece matéria prima para a produção de energia, para a indústria de transformação e para a construção. 
Segundo o Serviço Florestal Brasileiro ${ }^{36}$ (SFB, 2013) o Brasil possui a segunda maior cobertura florestal do mundo, ficando atrás apenas da Rússia. Destaca que as florestas ocupam aproximadamente 463 milhões de hectares, cerca de $54,4 \%$ do território brasileiro, sendo 456 milhões de hectares $(98,49 \%)$ de florestas naturais e 7 milhões de hectares $(1,51 \%)$ de florestas plantadas, principalmente com espécies dos gêneros Eucalyptus e Pinus, que representam $92,8 \%$ do total e colocam o Brasil na $8^{\text {a }}$ posição mundial.

Os Gráfico 2,Gráfico 3 eGráfico 4 apresentam dados referentes à produção total de madeira (extração vegetal e silvicultura) destinada a carvão vegetal, lenha e madeira em tora, da Food and Agriculture Organization of The United Nations (FAO) de 1961 a 2014, comparados aos dados nacionais do Instituto Brasileiro de Geografia e Estatística (IBGE), de 1990 a 2013.

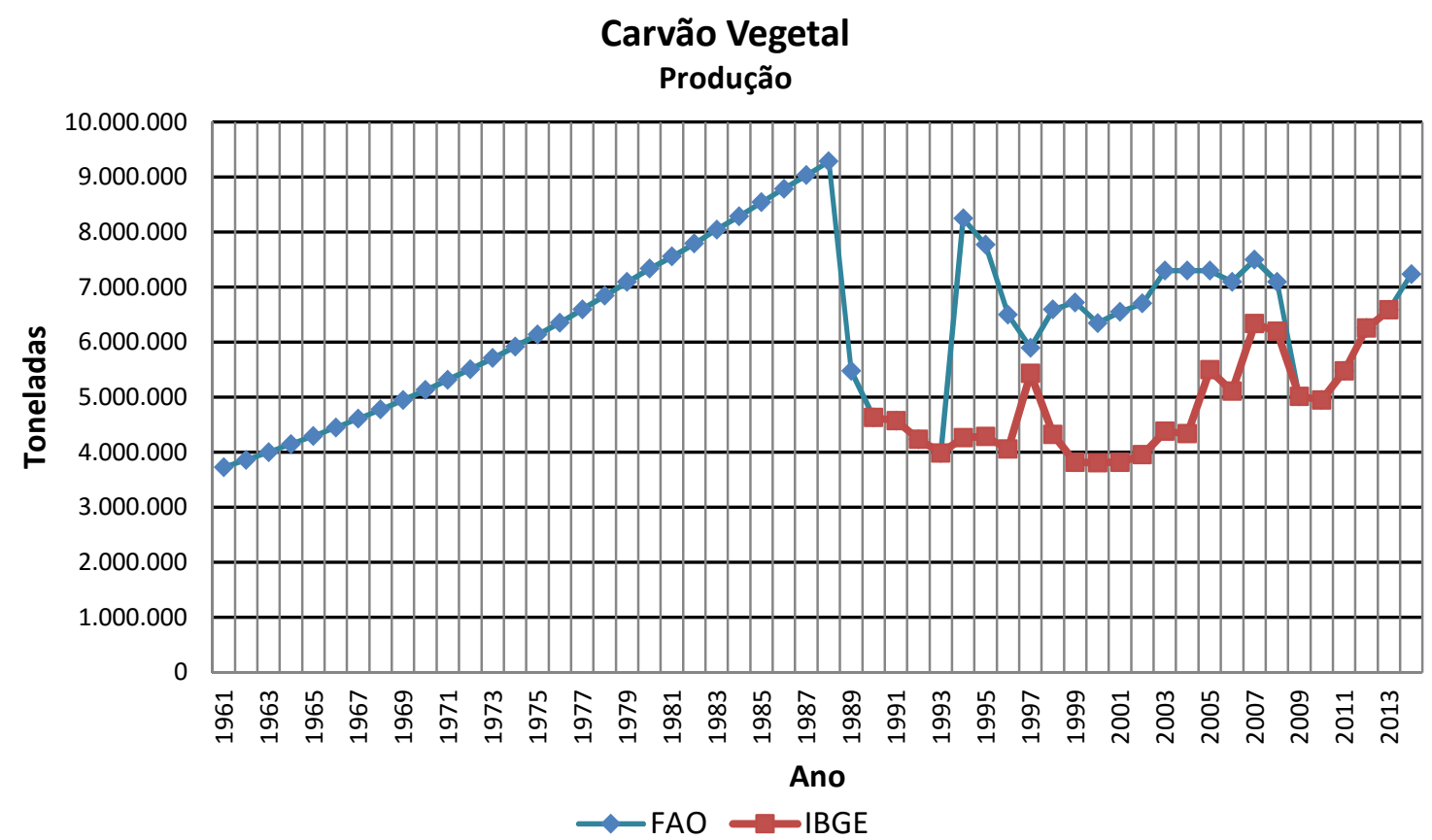

Gráfico 2 - Madeira destinada a carvão vegetal

Fonte: (FAO, 2016) e Adaptação das Tabelas 289 e 291 - Quantidade produzida na extração vegetal e silvicultura, por tipo de produto extrativo. http://www.sidra.ibge.gov.br/bda/tabela/listabl.asp?c=289 e http://www.sidra.ibge.gov.br/bda/tabela/listabl.asp?c=291

Nota-se uma diferença expressiva nos valores apresentados pelos dois órgãos, principalmente entre 1994 e 1996 e entre 1998 a 2006, com média de

\footnotetext{
36 O Serviço Florestal Brasileiro (SFB) é o órgão gestor das florestas públicas federais para a produção sustentável de bens e serviços. Possui também a responsabilidade de geração de informações, capacitação e fomento na área florestal. Disponível em: www.florestal.gov.br. Acesso em 15 jul. 2015.
} 
aproximadamente 3 milhões de toneladas. Após 2007 os valores foram se aproximando, tornando-se praticamente coincidentes de 2009 em diante. Tal discrepância pode ter origem na madeira nativa queimada de forma ilegal para a produção de carvão vegetal.

Um fato relevante é o crescimento da utilização da madeira para este fim desde 1961 até 1998, passando de 3.731.632 t para 9.286.079 t, representando um aumento da ordem de $248 \%$. Após isso, ocorreu uma queda e uma posterior estabilização, devido à um aumento da utilização da madeira para outros fins mais nobres.

Lenha

Produção

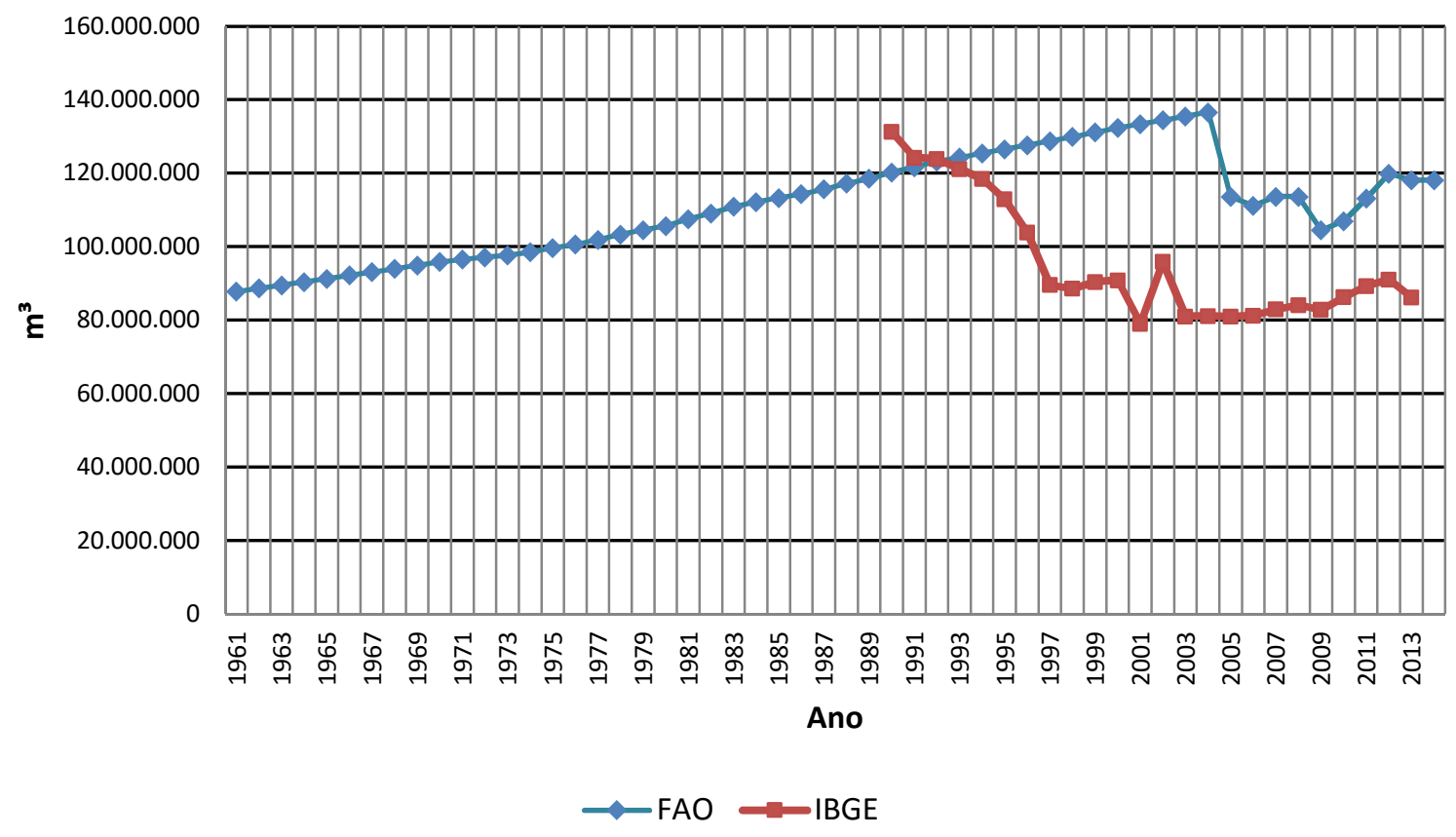

Gráfico 3 - Madeira de extrativismo vegetal e silvicultura destinada a lenha

Fonte: (FAO, 2016) e Adaptação das Tabelas 289 e 291 - Quantidade produzida na extração vegetal e silvicultura, por tipo de produto extrativo. http://www.sidra.ibge.gov.br/bda/tabela/listabl.asp?c=289 e http://www.sidra.ibge.gov.br/bda/tabela/listabl.asp?c=291

Novamente nota-se uma expressiva diferença entre os dados, com variação máxima da ordem de 55,5 milhões de $\mathrm{m}^{3}$ e média de 34,5 milhões $\mathrm{m}^{3}$, além de um contínuo crescimento da utilização da madeira como lenha desde 1961 a 2004, de $87.851 .504 \mathrm{~m}^{3}$ para $136.636 .745 \mathrm{~m}^{3}$, da ordem de $64 \%$. 


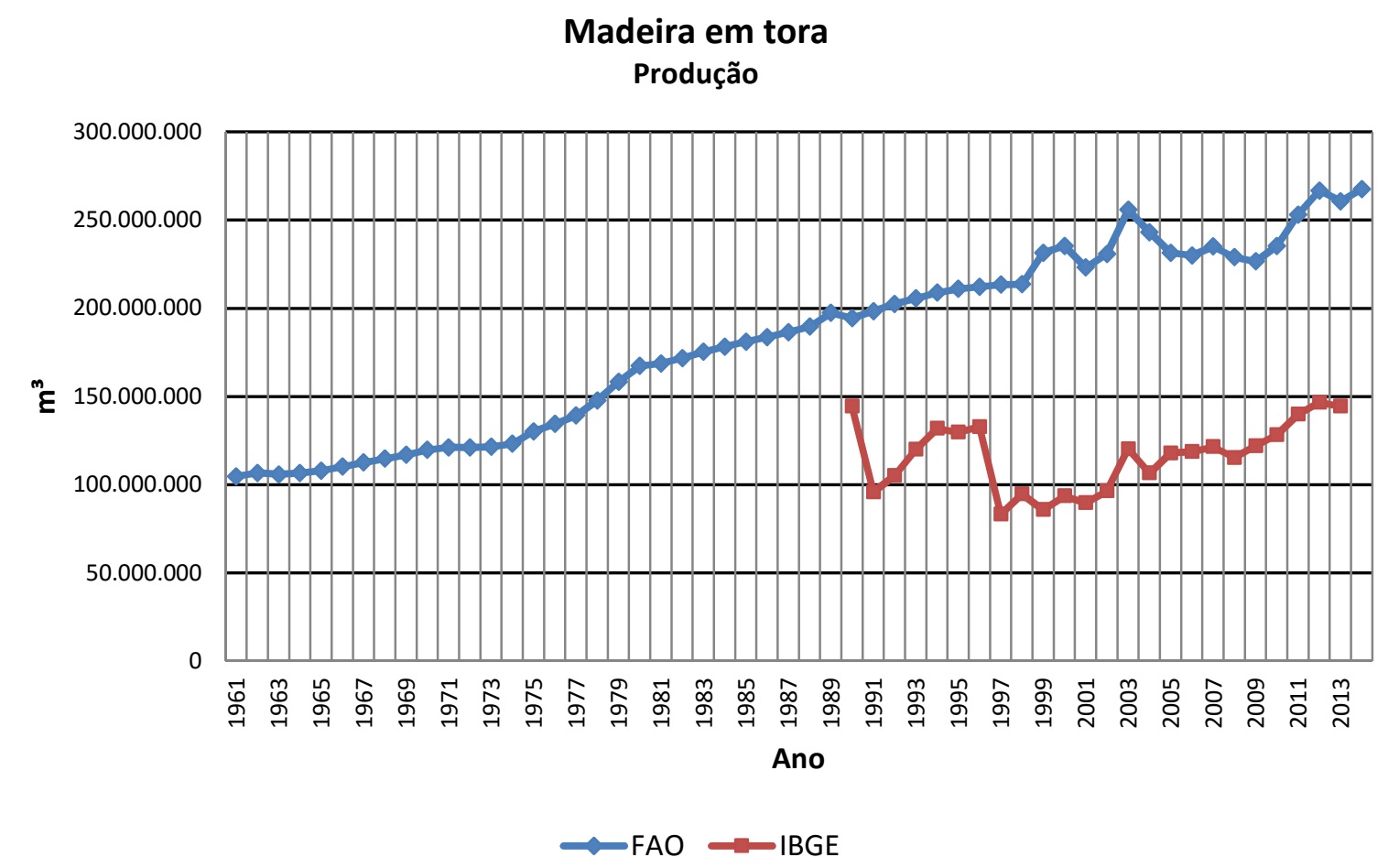

Gráfico 4 - Madeira de extrativismo vegetal e silvicultura - madeira em tora

Fonte: (FAO, 2016) e Adaptação das Tabelas 289 e 291 - Quantidade produzida na extração vegetal e silvicultura, por tipo de produto extrativo. http://www.sidra.ibge.gov.br/bda/tabela/listabl.asp?c=289 e http://www.sidra.ibge.gov.br/bda/tabela/listabl.asp?c=291

Para a madeira em tora os valores disponibilizados pela FAO e IBGE são ainda mais discrepantes, contando com uma variação máxima da ordem de 145,6 milhões $\mathrm{m}^{3}$ e média de 112,5 milhões $\mathrm{m}^{3}$, sendo que os dados da FAO apresentam um crescimento praticamente contínuo desde 1961 até 2014 , de $104.811 .504 \mathrm{~m}^{3}$ para $267.653 .000 \mathrm{~m}^{3}$, aproximadamente $255 \%$.

Nota-se, em todos os gráficos anteriormente apresentados, que os valores disponibilizados pela FAO são, quase sempre, superiores aos dos disponibilizados pelo IBGE, fato que pode ser compreendido pela história de exploração ilegal da madeira da floresta Amazônica, controlada nos últimos anos por estratégias de manejo e certificação florestal da madeira nativa.

A FAO também apresenta dados referentes à produção de madeira serrada e MDF, apresentados nos Gráfico 5 eGráfico 6. 


\section{Madeira Serrada \\ Produção}

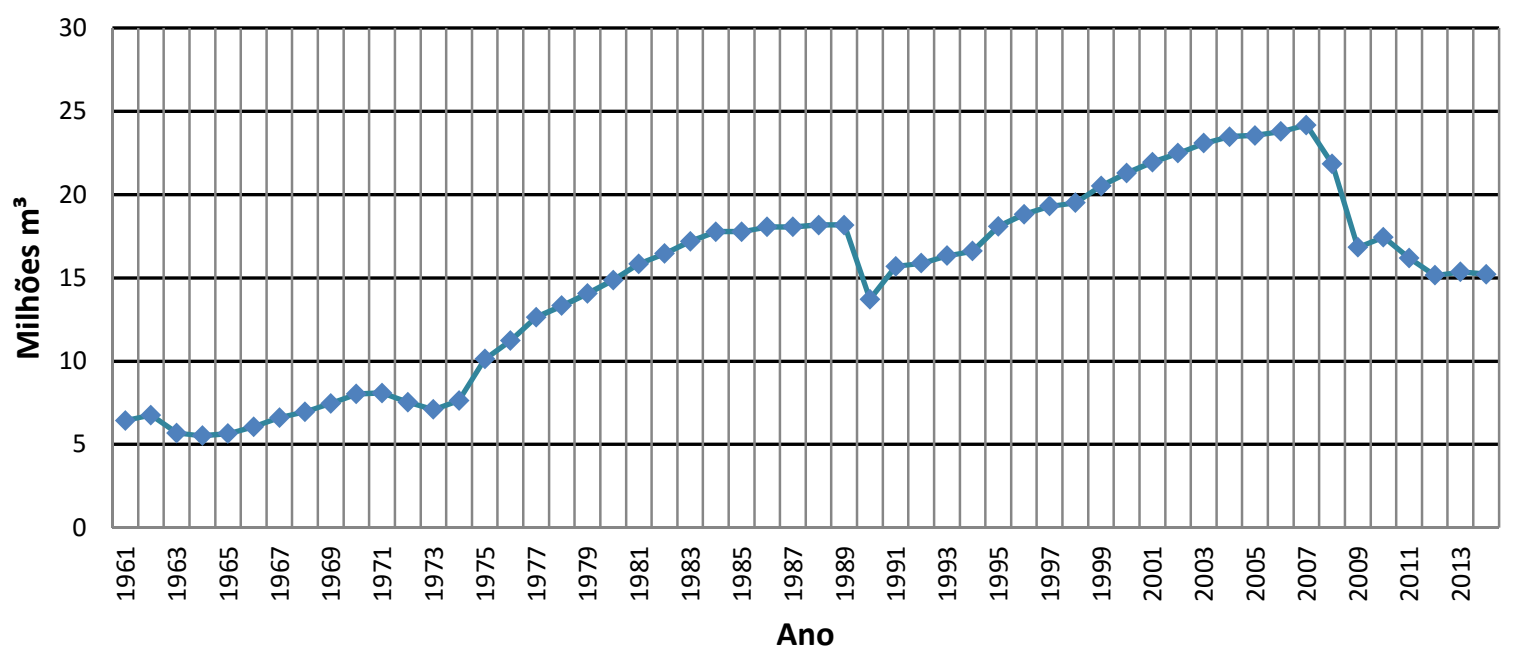

Gráfico 5 - Produção total de madeira serrada

Fonte: FAO (2016)

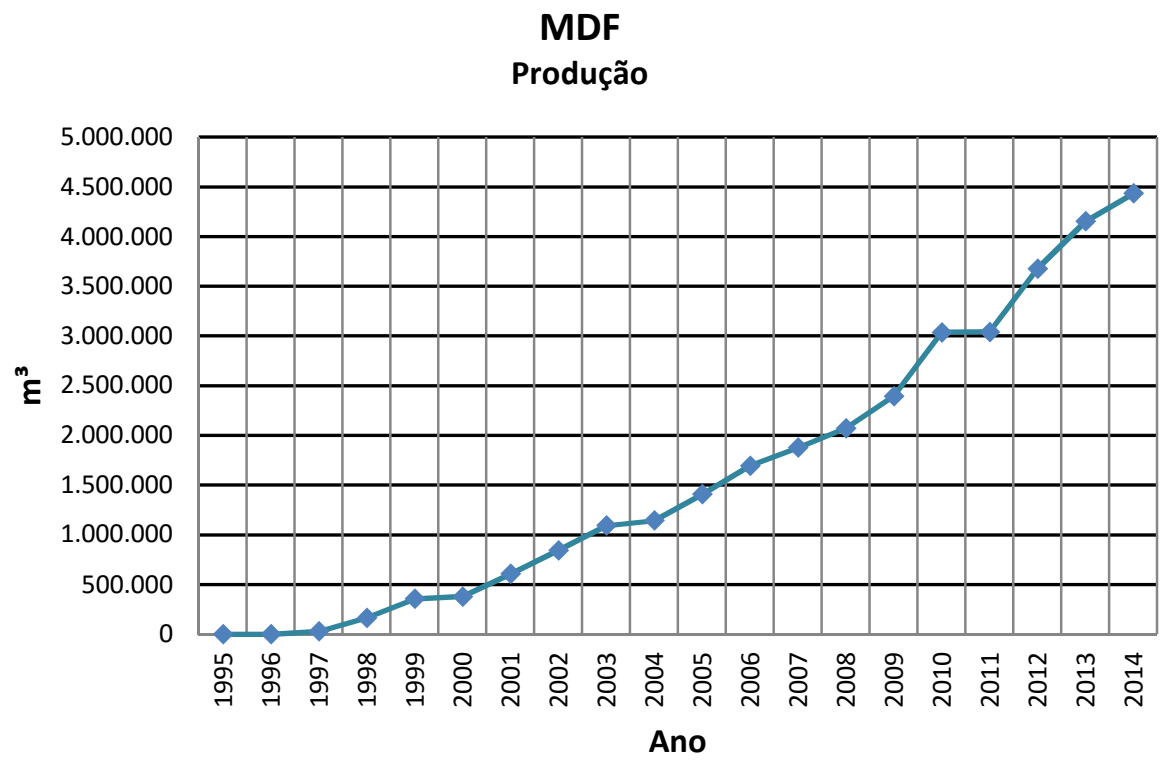

Gráfico 6 - Produção total de MDF

Fonte: FAO (2016)

Nota-se em ambos os gráficos um crescimento praticamente contínuo ao longo do período apresentado, com exceção para a madeira serrada, que vem apresentando uma queda desde 2007, possivelmente devido aos mesmos processos de manejo, certificação e aumento do controle sobre as florestas nativas. 
Segundo Punhagui (2014), o Brasil é um dos maiores produtores e exportadores de madeira do mundo, ainda sim a demanda interna é baixa, existindo um enorme potencial que pode ser melhor aproveitado.

\subsection{A SITUAÇÃO FLORESTAL BRASILEIRA - FLORESTAS NATIVAS E PLANTADAS}

\subsubsection{As florestas nativas}

A maior parte da madeira nativa é proveniente da Amazônia Legal, localizada na região norte do país conforme apresentado na Figura 7. Essa região conta com uma floresta tropical úmida com cerca de 150 a 562 toneladas de biomassa (seca sobre o solo) por hectare e uma outra região, denominada serrado (CAMPOS, 2012). Estima-se que há mais de 11.000 espécies arbóreas na Amazônia (SNIF, 2015), mas somente entre 60 e 80 são comerciais e 40 estão catalogadas como técnica e economicamente viáveis (ADEODATO et al., 2011).

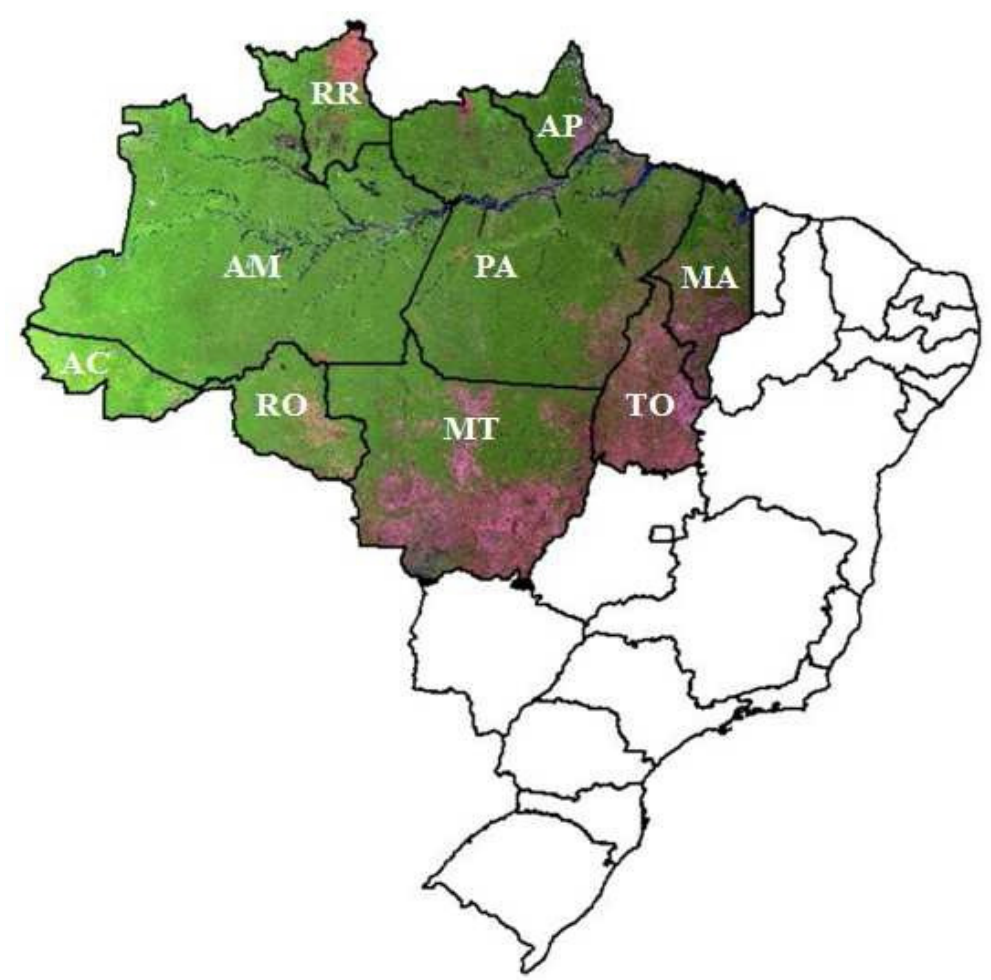

Figura 7 - Madeira nativa - Estados da Amazônia Legal Fonte: PUNHAGUI (2014) 
As florestas certificadas do Brasil representam, frente ao total mundial, apenas $4 \%$, enquanto que as da Rússia a $18 \%$ e do Canadá equivalem a $33 \%$ (SANTOS; PEREIRA; VERÍSSIMO, 2013), além disso, o volume de madeira certificada extraída representa entre $3 \%$ a $4 \%$ do total. Segundo dados do Forest Stewardship Council (FSC) ${ }^{37}$, as áreas certificadas no Brasil correspondiam a 7\% do total em 2014 (AGEFLOR, 2015). Uma parte desta madeira (32\%) se destina ao mercado interno, principalmente para São Paulo e a região Nordeste, enquanto que o restante (68\%) se destina à exportação (ADEODATO, 2011 e LENTINI; GOMES; SOBRAL, 2011).

Segundo Punhagui (2014) dos 6,3 milhões de hectares certificados em 2011, $20 \%$ foram de florestas nativas na Amazônia e $80 \%$ florestas plantadas das regiões sudeste e nordeste.

A autora destaca ainda que $72 \%$ da produção de madeira se destina a bens com baixo valor agregado (madeira serrada), $15 \%$ a produtos com algum valor agregado (madeira aplainada, pisos e batentes), 13\% a madeira laminada e compensada.

Em 2009, 51\% dos resíduos gerados no processo produtivo foram utilizados para fins energéticos (energia, carvão e cerâmica), 24\% para fins diversos (lenha, fertilizantes e aterros sanitários, entre outros) e $25 \%$ não tiveram nenhum destino (SFB; IMAZON, 2010).

De toda a madeira nativa extraída da Amazônia Legal consumida no mercado interno em 2011 (cerca de 5,5 milhões $\mathrm{m}^{3}$ ), os principais destinos foram os Estados de São Paulo com 23\% e Minas Gerais e Paraná, ambos com 10\%. O restante foi distribuído em vários outros estados, conforme Figura 8.

\footnotetext{
37 O FSC, Forest Stewardship Council, fundado em 1933, é uma organização independente, não governamental,
} sem fins lucrativos, criada para promover o manejo florestal responsável ao redor do mundo. (AGEFLOR, 2014) 


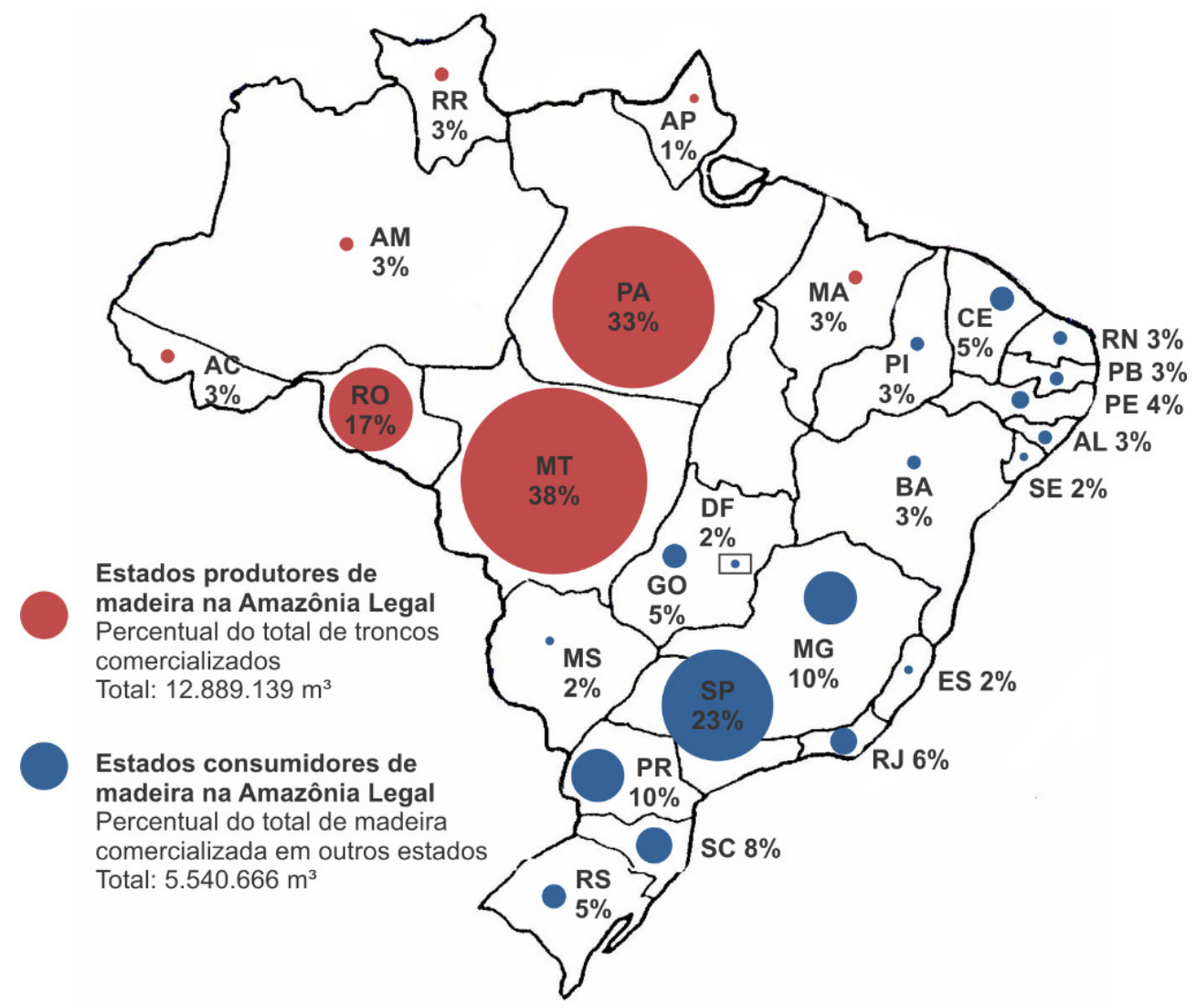

Figura 8 - Estados produtores e consumidores da madeira da Amazônia Legal em 2011 Fonte: Adaptado de PUNHAGUI (2014)

A busca pela madeira tropical está diretamente relacionada à sua densidade, por ser menos suscetível à biodeterioração quando comparada à madeira de florestas plantadas, que possui menor densidade e necessita de tratamento químico para sua conversação.

Para que a madeira nativa possa chegar aos consumidores, ela passa por diversas fases, desde sua extração até o transporte: preparação anterior à extração (abertura de vias e pátios de armazenamento na floresta), extração da árvore (corte e arraste do tronco), transporte dentro da floresta, armazenamento na floresta, transporte até a serraria, processamento e transporte até o consumidor, conforme apresentado no Quadro 1 (PUNHAGUI, 2014). 


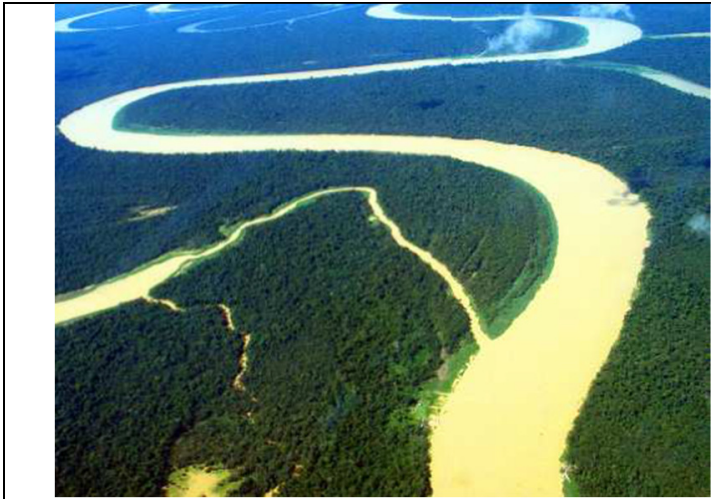

1 - Floresta amazônica (antes da extração)

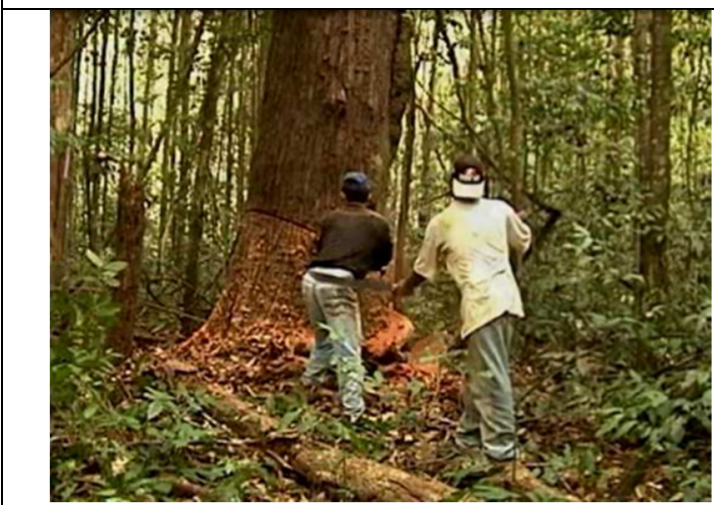

3 - Extração (corte da árvore)

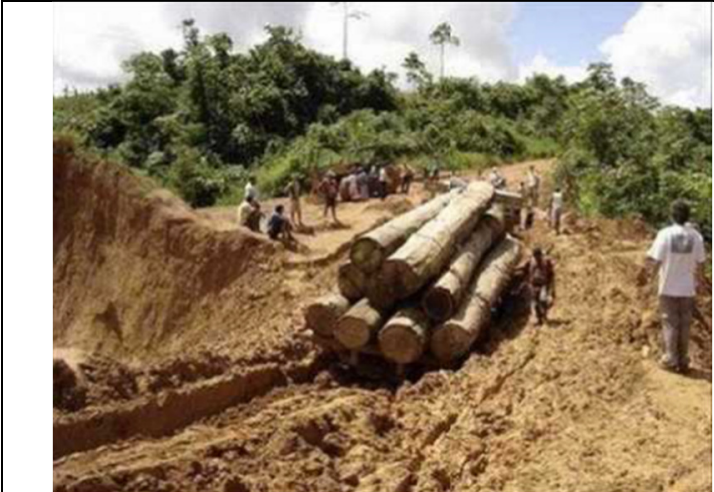

5 - Transporte na floresta (arraste da árvore)

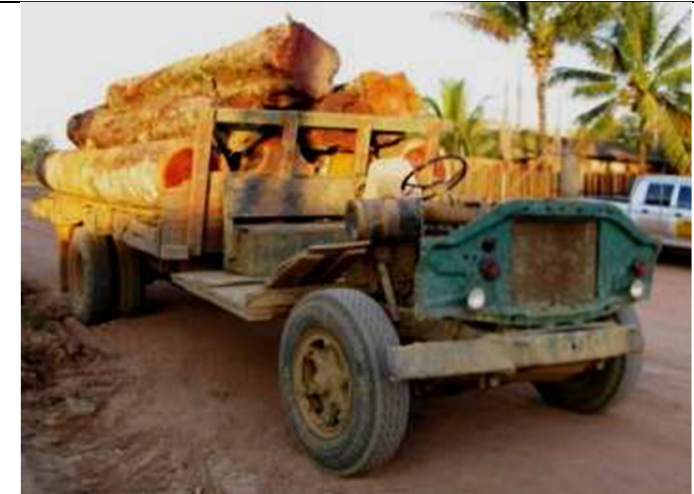

7 - Transporte desde a floresta até o lugar de processamento

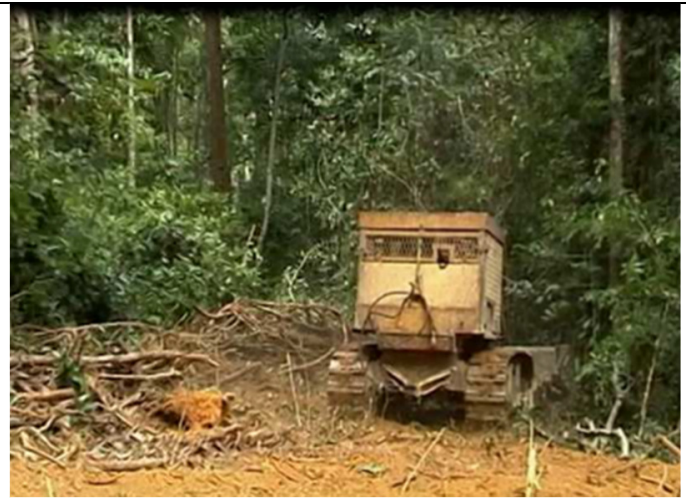

2 - Abertura de vias de acesso e pátios de armazenamento

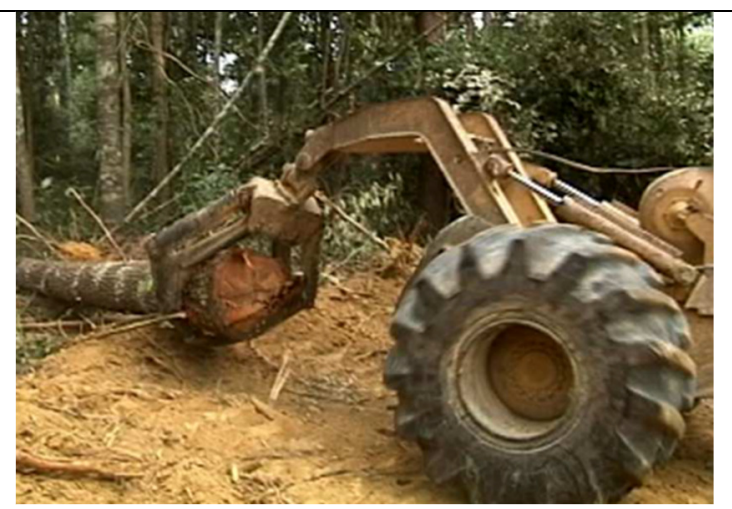

4 - Extração (arraste da árvore)

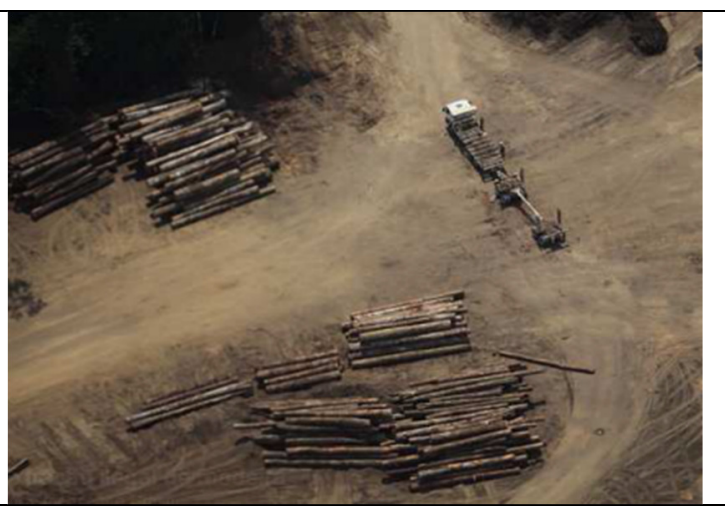

6 - Armazenamento na floresta

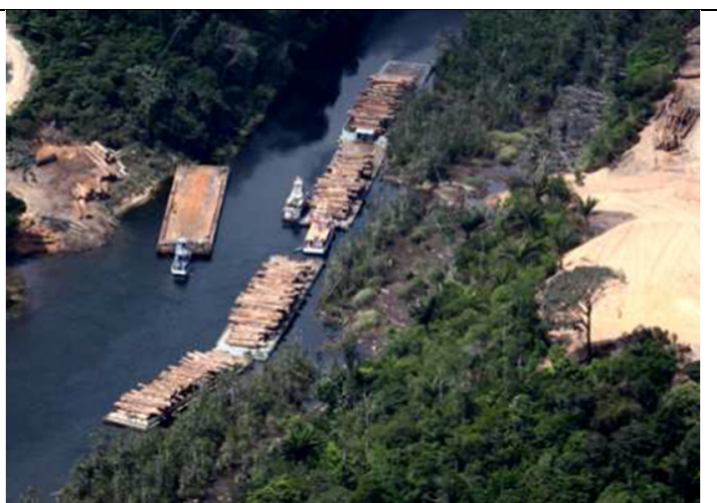

8 - Transporte desde a floresta até o lugar de processamento (vía fluvial quando necessário) 


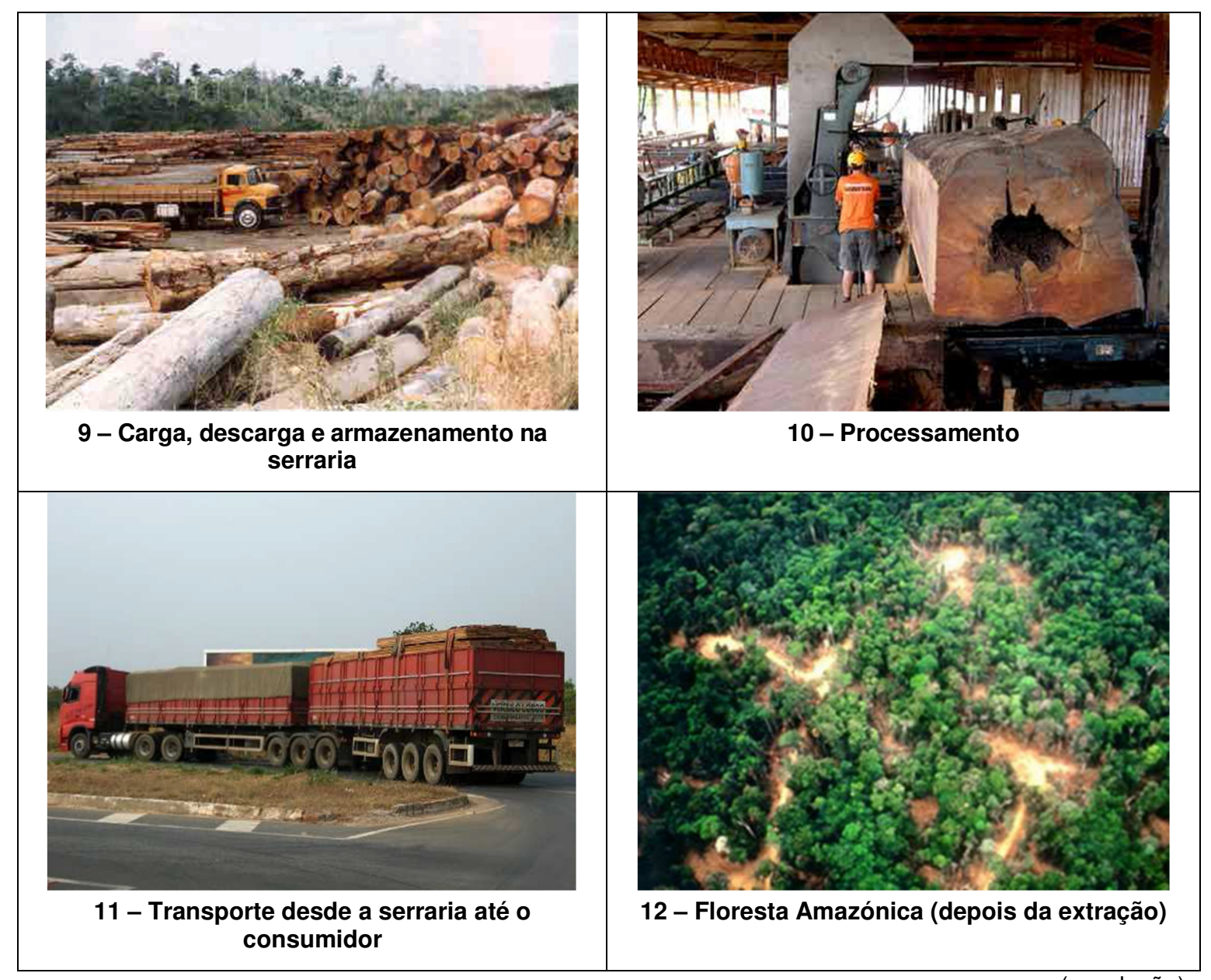

(conclusão)

Quadro 1 - Cadeia produtiva da madeira nativa

Fonte: Adaptado de PUNHAGUI (2014)

Notam-se, na imagem da Selva Amazônica após a extração das toras, os rastros deixados pela abertura dos pátios de armazenamento temporário das toras, durante o trabalho de extração e os caminhos abertos pelos equipamentos pesados utilizados para o arraste das árvores extraídas.

\subsubsection{As florestas plantadas}

O Brasil, em 2010, encontrava-se na oitava posição mundial de superfície de florestas plantadas (SFB, 2013). Em 2012, a área brasileira de plantios de Eucalyptus e Pinus atingiu 6,66 milhões de hectares, que representaram $76,6 \%$ e 23,4\% respectivamente. (ABRAF, 2013)

A madeira plantada é proveniente de florestas localizadas majoritariamente na região sudeste do país, conforme apresentado nas Figura 9 eFigura 10. 
Consideradas como monocultivo, sua produtividade é de aproximadamente $40 \mathrm{~m}^{3} / \mathrm{ha}$.ano, maior que em países como a Finlândia, Suécia e Chile, tradicionalmente madeireiros. Os gêneros predominantes são o Eucalyptus e o Pinus (ABRAF, 2015).

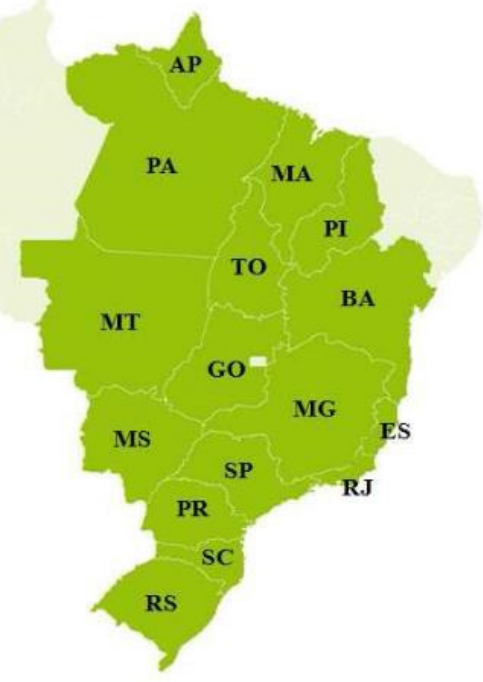

Figura 9 - Madeira plantada. Estados produtores de Eucalyptus

Fonte: PUNHAGUI (2014)

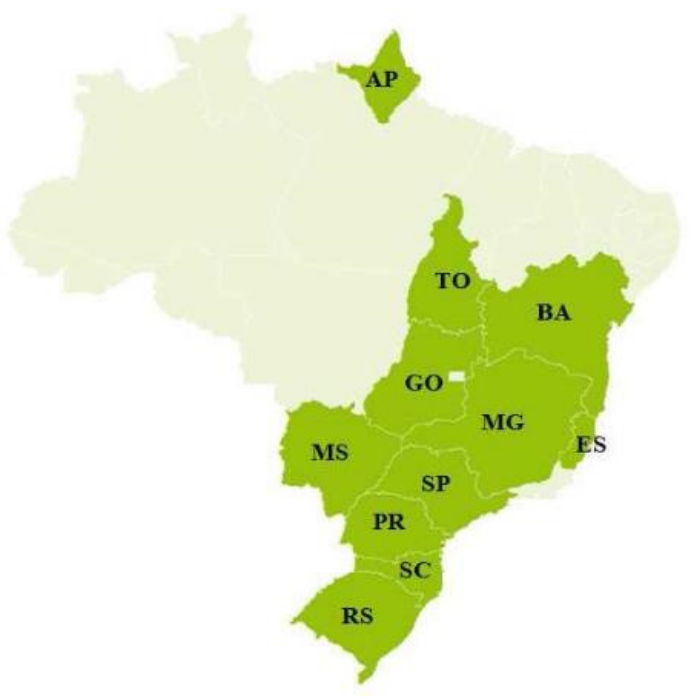

Figura 10 - Madeira plantada. Estados produtores de Pinus

Fonte: PUNHAGUI (2014)

Os estados com as maiores superfícies de plantio são Minas Gerais, São Paulo, Paraná e Santa Catarina, conforme apresentado na Figura 11, justamente por ser nestes estados que se concentram a maioria das unidades industriais e centros consumidores.

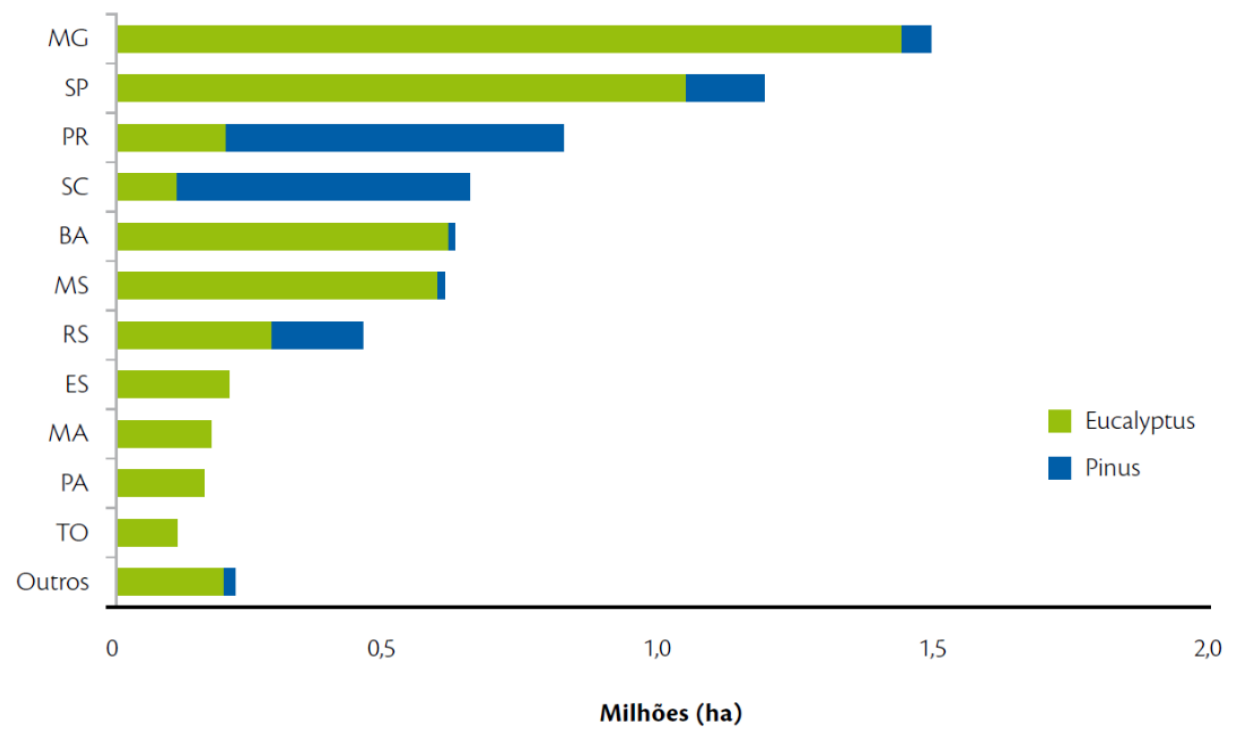

Figura 11 - Distribuição da área de plantios florestais com Pinus e Eucalyptus no Brasil, 2012 Fonte: ABRAF (2013) 
A grande produtividade da silvicultura brasileira se dá devido a um conjunto de situações, tais como as condições climáticas e fundiárias, investimentos em pesquisas e desenvolvimento para melhora genética, otimização de áreas de manejo e a qualidade da mão de obra empregada. Estes fatores proporcionam um menor ciclo de colheita, o que confere ao Brasil, uma posição de destaque no cenário mundial, verificada no Gráfico 7 (ABRAF, 2013).

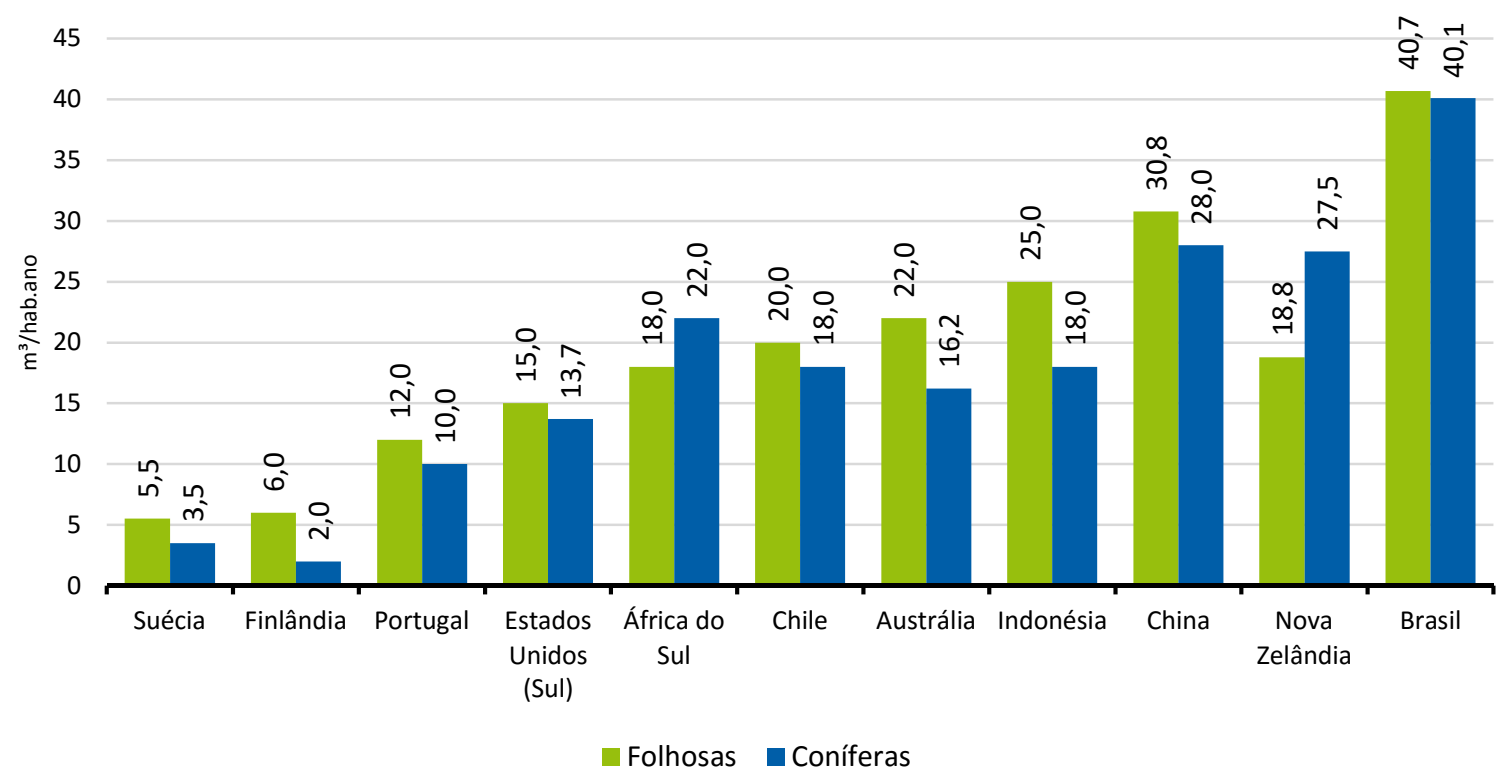

Gráfico 7 - Comparação da produtividade florestal de coníferas e de folhosas no Brasil com países selecionados, 2012

Fonte: ABRAF (2013)

Pode-se constatar que, no Brasil, não há problema quanto ao fornecimento de madeira plantada, pois na Suécia, país onde a madeira é largamente utilizada, notase que sua produtividade é muito inferior à brasileira, representando apenas $13,51 \%$ para as folhosas e $8,73 \%$ para coníferas.

As dimensões continentais do Brasil favoreceram o desenvolvimento do parque industrial de base florestal ao longo de todo o seu território, contribuindo para a diversificação da cadeia produtiva de madeira plantada, destacando-se a produção de chapas de madeira industrializada, madeira processada mecanicamente, madeira tratada, celulose e papel, carvão vegetal para siderurgia e biomassa para energia. Contudo, as indústrias e empresas se concentram principalmente nas regiões sul e sudeste, devido a aspectos regionais e logísticos que contribuem para o aumento dos níveis de competitividade. 
A Figura 12 apresenta a localização das principais empresas e polos consumidores de madeira de florestas plantadas no Brasil no ano de 2012.

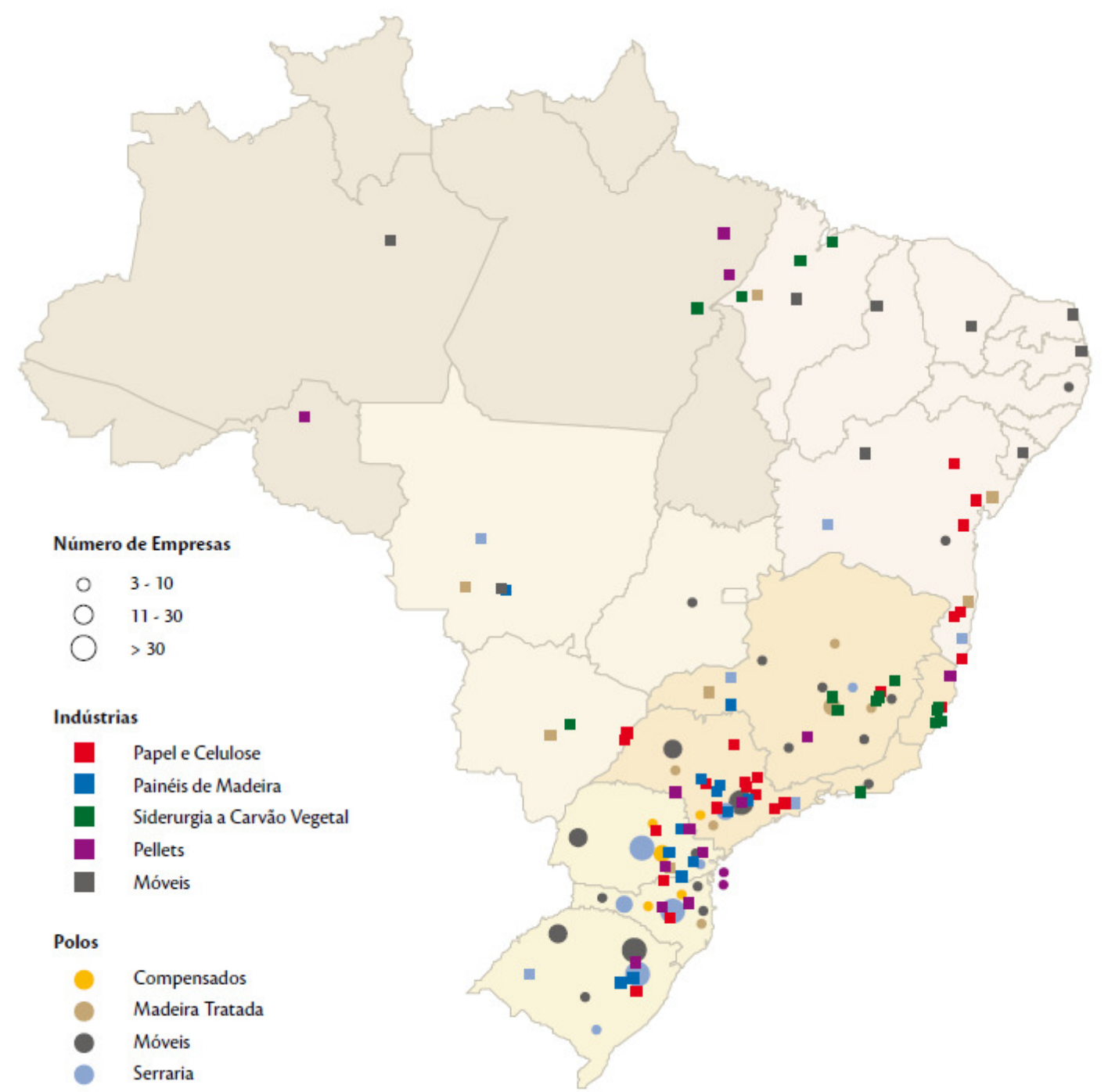

Figura 12 - Localização das principais empresas e polos consumidores de madeira de florestas plantadas no Brasil, 2012

Fonte: ABRAF (2013)

Essa concentração das empresas se justifica também pelo mercado potencial devido ao fato de que nas regiões sul e sudeste a população passa dos 107 milhões de pessoas, que representa cerca de $56 \%$ do total do país (IBGE, 2010).

Para que o produto de madeira plantada chegue aos consumidores, ela passa por diversas fases, sendo: produção de sementes; preparação do solo; plantio; crescimento (absorção de $\mathrm{CO}_{2}$ e incorporação de carbono), manutenção e conservação da árvore até a sua idade de corte; extração; armazenamento na 
floresta; transporte até a serraria ou indústria; processamento e; transporte até o consumidor ou distribuidor (PUNHAGUI, 2014), conforme apresentado no Quadro 2.

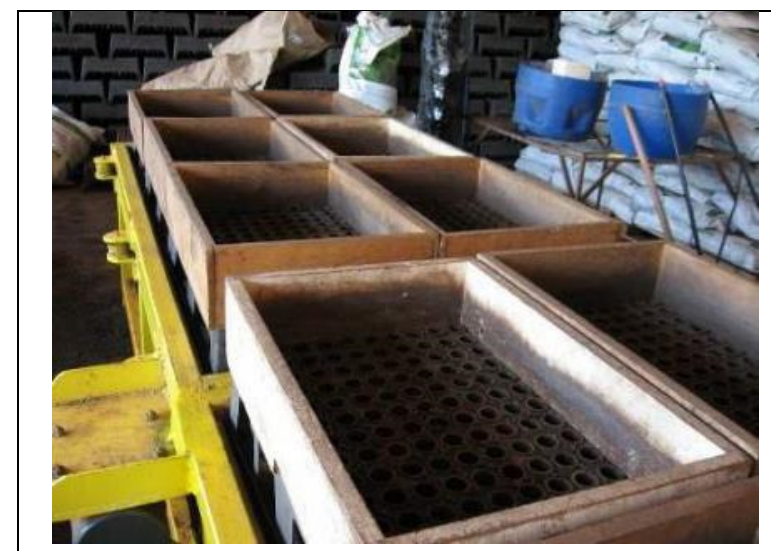

1 - Manejo de sementes

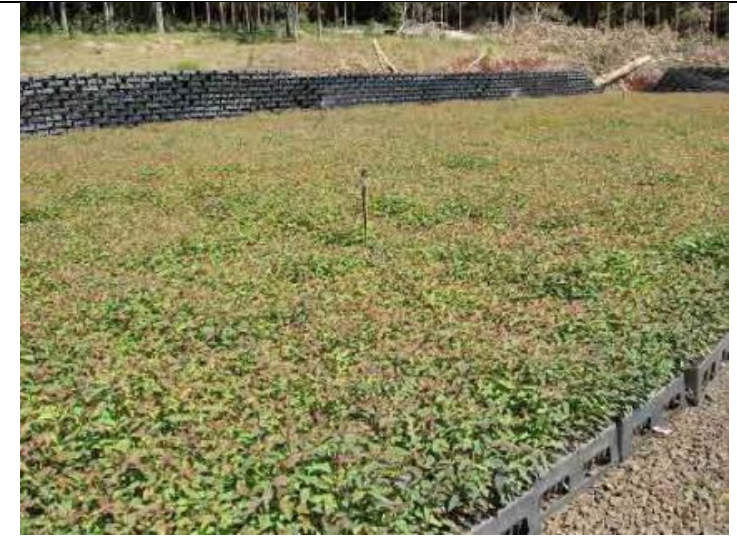

2 - Produção de mudas

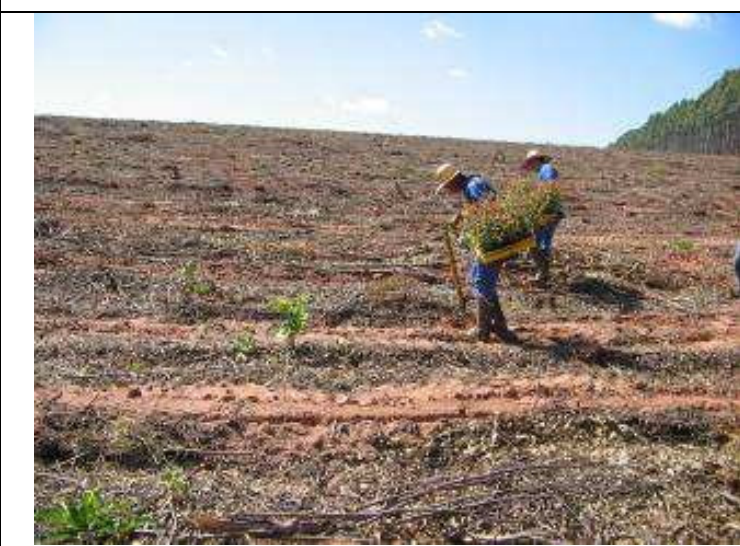

3 - Preparação do solo e plantio

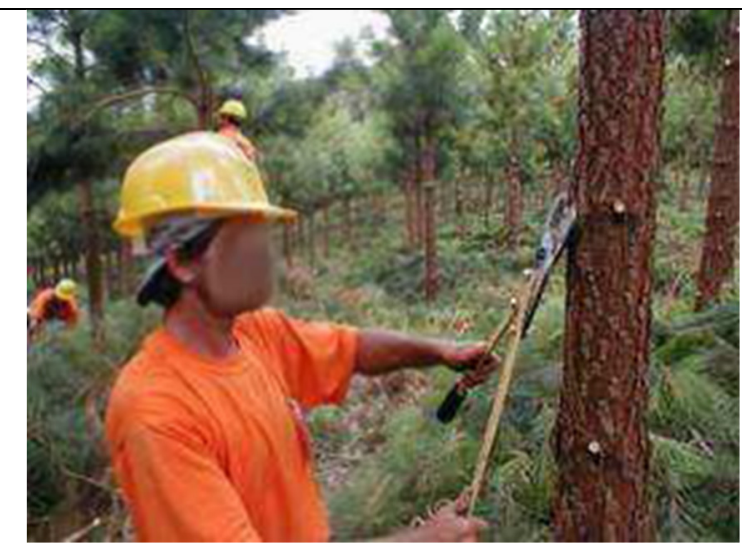

5 - Manutenção e conservação

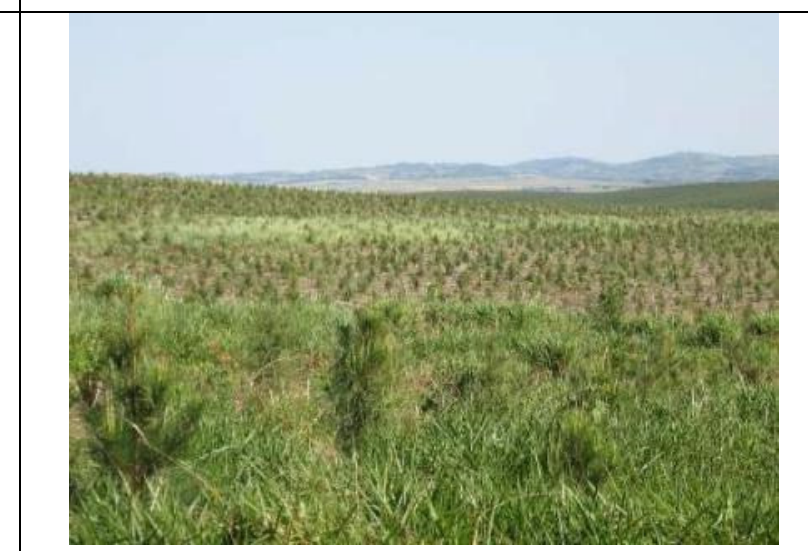

4 - Crescimento

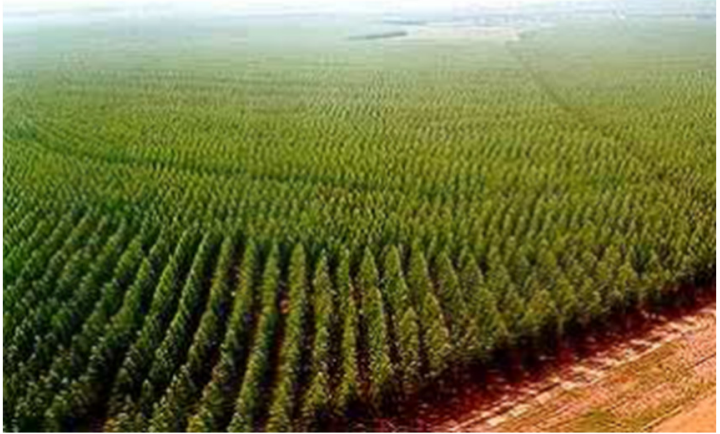

6 - Plantação com idade de corte 


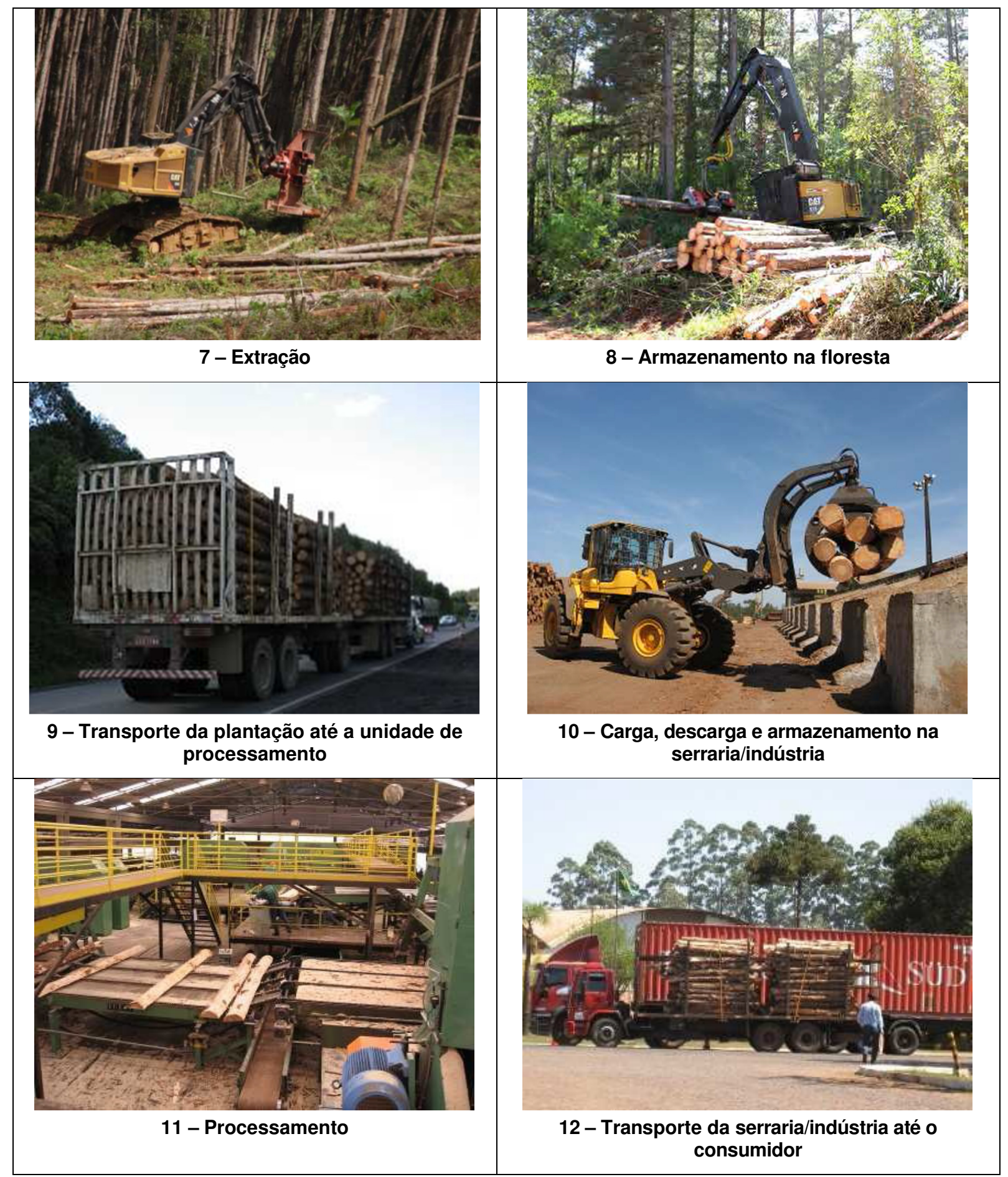

(conclusão)

Quadro 2 - Cadeia produtiva da madeira nativa

Fonte: Adaptado de PUNHAGUI (2014) 


\subsection{POTENCIAL DA UTILIZAÇÃO DA MADEIRA DE FLORESTAS PLANTADAS}

A cadeia produtiva do setor brasileiro de florestas plantadas caracteriza-se pela sua grande diversidade, contribuindo com uma parcela importante na geração de produtos, tributos, empregos e bem-estar, tanto para segmentos industriais, na fabricação de celulose e papel, painéis de madeira industrializada, processamento mecânico, madeira tratada, siderurgia a carvão vegetal e geração de energia, destinados principalmente à construção civil quanto para produtos não madeireiros como óleos, corantes, resinas, borracha natural, destinados à indústria química, farmacêutica e ramo alimentício. Além das funções e aplicações descritas acima, a produção florestal possui uma importante função ambiental, contribuindo para a conservação e preservação dos recursos naturais, destacando-se a regulação do solo, qualidade do ar e do clima, fixação de carbono, além de possuir valor estético, artístico e científico.

Do ponto de vista ambiental, se faz necessário e de extrema importância a gestão responsável das florestas plantadas, para que se ofereça uma alternativa economicamente sustentável na oferta de madeira, contribuindo para uma redução da pressão sobre as florestas nativas, permitindo a preservação e conservação das mesmas. Segundo o Sistema Nacional de Informações Florestais ${ }^{38}$ (SNIF, 2015), o Brasil detém hoje as melhores tecnologias na silvicultura do Eucalyptus, que apesar de sua relevância na economia nacional é um setor contraditório, pois ao mesmo tempo em que desenvolveu a silvicultura de florestas plantadas com produção integrada e estrutura produtiva sofisticada, ainda convive com altos índices de desmatamento ilegal de florestas nativas.

A seguir são apresentados nos Gráfico 8,Gráfico 9 e Gráfico 10 valores comparativos entre a produção de madeira de extrativismo vegetal e origem silviculturais destinados à produção de carvão vegetal, lenha e madeira em tora, onde observa-se uma redução do volume de madeira proveniente do extrativismo vegetal e um aumento gradativo de madeira de origem silvicultural.

\footnotetext{
38 O Serviço Florestal tem trabalhado para a implementação do SNIF como um sistema de identificação, registro e análise de informações associadas às florestas naturais e plantadas do Brasil. Esse trabalho está no seu início e a sua ampliação e domínio pela sociedade brasileira demandará a participação e contribuição de todos, especialmente das entidades produtoras de informações florestais. O SNIF tem como objetivo colecionar e produzir, organizar, armazenar, processar e disseminar dados, informações e conhecimentos sobre as florestas e o setor florestal, de modo a subsidiar projetos e políticas que conciliem o uso e a conservação das florestas do Brasil
} 
A produção de madeira nativa tem diminuído nos últimos anos devido à crise econômica de 2009, à maior fiscalização e a crescente substituição da madeira nativa pela madeira plantada (ADEODATO, 2011; PEREIRA et al., 2010; SFB, 2010).

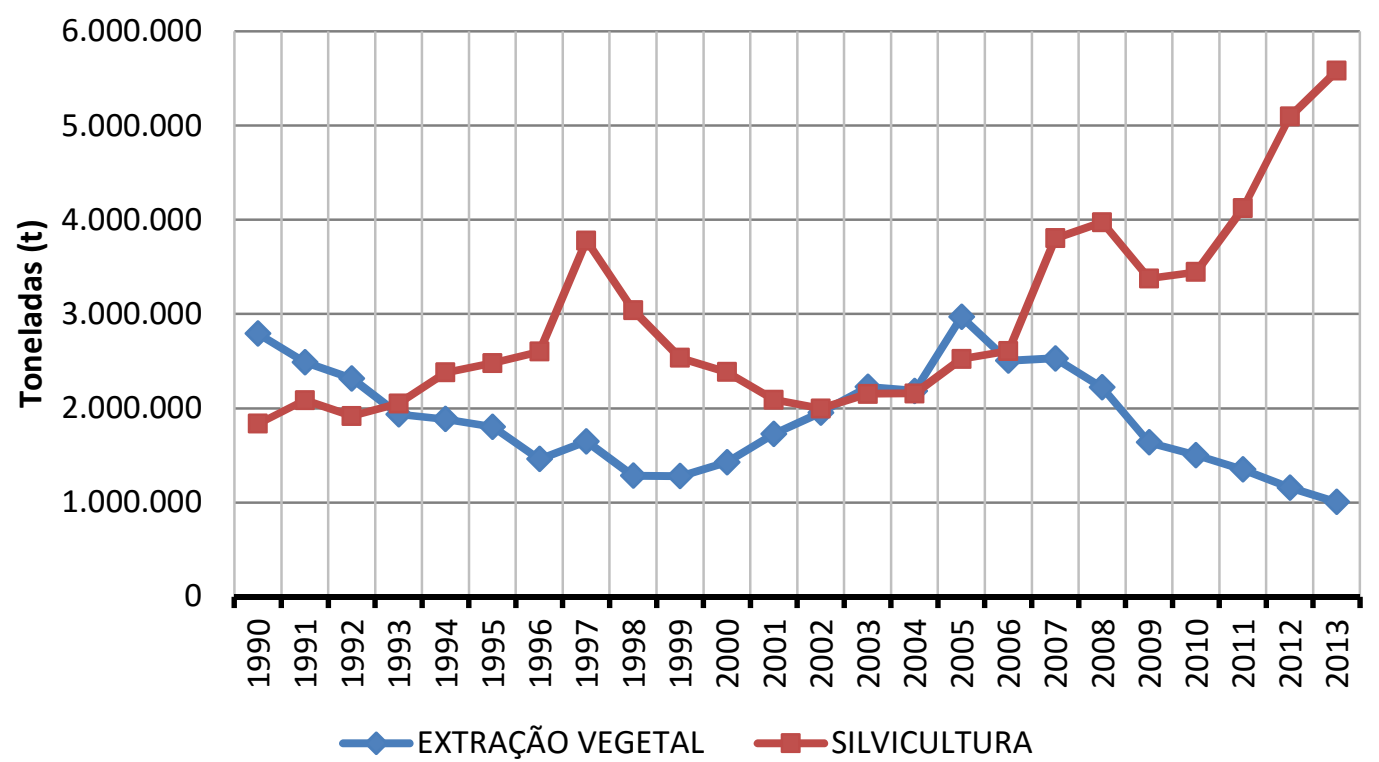

Gráfico 8 - Madeira de extrativismo vegetal e silvicultura destinada a carvão vegetal Fonte: Adaptado das Tabelas 289 e 291 - Quantidade produzida na extração vegetal e silvicultura, por tipo de produto extrativo. http://www.sidra.ibge.gov.br/bda/tabela/listabl.asp?c=289 e http://www.sidra.ibge.gov.br/bda/tabela/listabl.asp?c=291

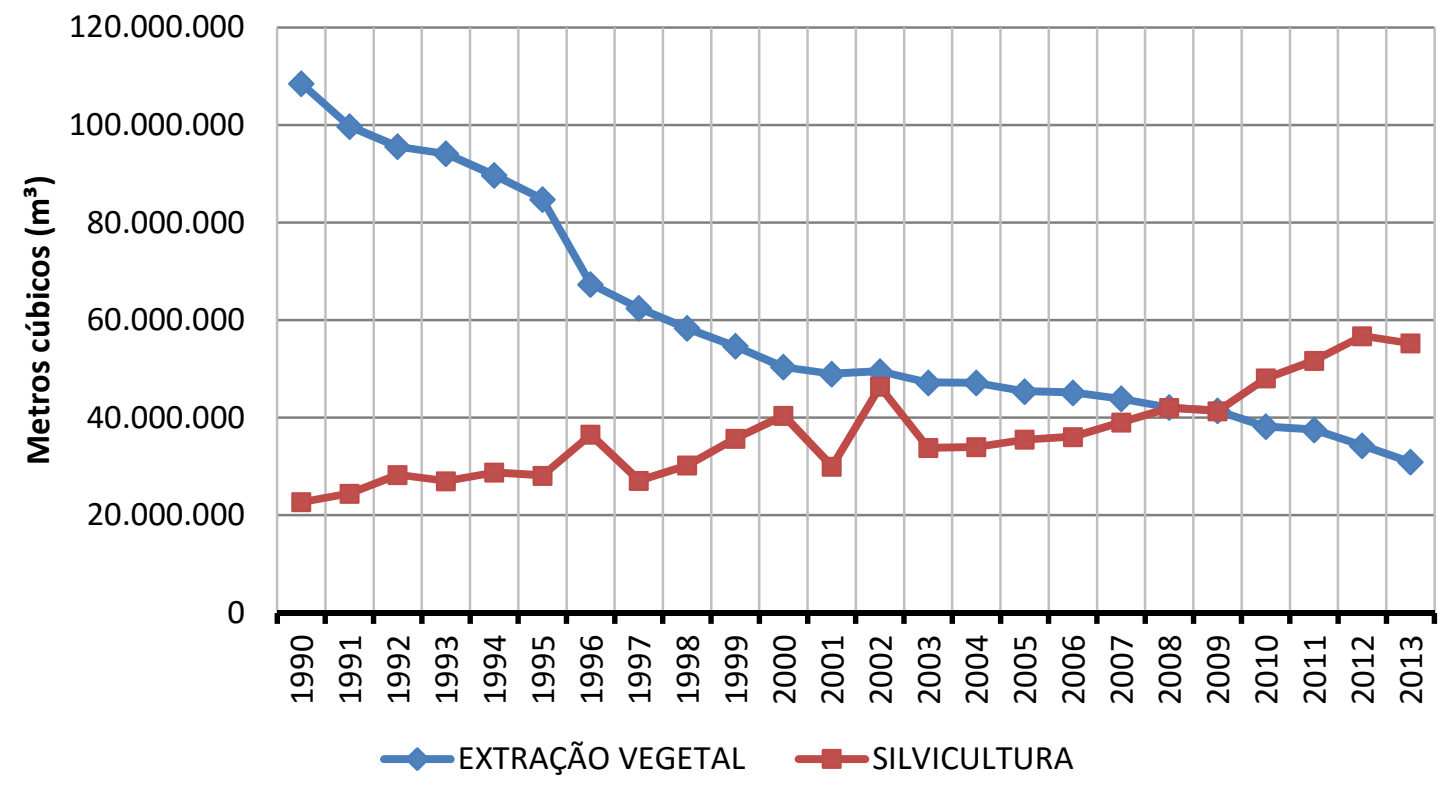

Gráfico 9 - Madeira de extrativismo vegetal e silvicultura destinada a lenha

Fonte: Adaptado das Tabelas 289 e 291 - Quantidade produzida na extração vegetal e silvicultura, por tipo de produto extrativo. http://www.sidra.ibge.gov.br/bda/tabela/listabl.asp?c=289 e http://www.sidra.ibge.gov.br/bda/tabela/listabl.asp?c=291 


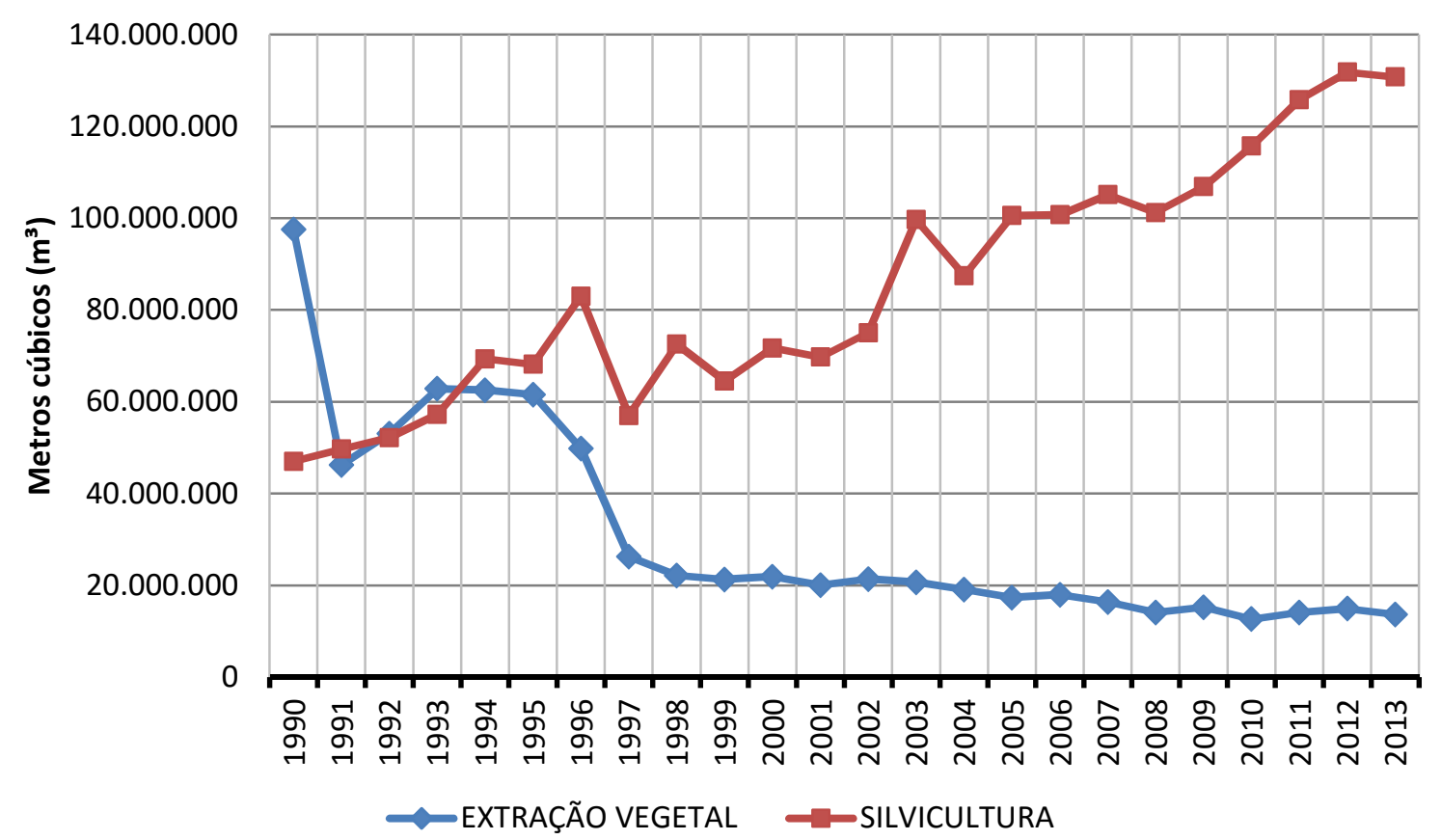

Gráfico 10 - Madeira em tora proveniente de extrativismo vegetal e silvicultura Fonte: Adaptado das Tabelas 289 e 291 - Quantidade produzida na extração vegetal e silvicultura, por tipo de produto extrativo. http://www.sidra.ibge.gov.br/bda/tabela/listabl.asp?c=289 e http://www.sidra.ibge.gov.br/bda/tabela/listabl.asp?c=291

Pode-se perceber em todos os gráficos, salvo a presença de alguns picos, que devem ser analisados isoladamente, levando-se em consideração o contexto do ano em questão, uma tendência de redução na utilização de madeira proveniente de florestas nativas em detrimento à de florestas plantadas.

No que diz respeito à oferta e à produção de madeira, de acordo com o Sistema Nacional de Informações Florestais (SNIF), em 2010, os dados estatísticos nacionais indicavam que a produção de madeira serrada correspondeu a 4,9 milhões de $\mathrm{m}^{3}$ e a produção de painéis a 6,4 milhões de $\mathrm{m}^{3}$, gerando 673 mil empregos formais no setor florestal. A extração de madeira em tora para combustível representou 133,1 milhões de $\mathrm{m}^{3}$ e a extração de madeira em tora para indústria 139,9 milhões de $\mathrm{m}^{3}$. Estima-se que o setor florestal foi responsável por 3,5\% do Produto Interno Bruto (PIB) de 2007 do Brasil, equivalente a US\$ 37,3 bilhões, e por $7,3 \%$ das exportações totais do país, equivalente a US\$10,3 bilhões, sendo o setor de celulose responsável por US\$ 4 bilhões, o de madeira serrada, compensados e produtos de maior valor agregado por US $\$ 2,9$ bilhões, o de móveis por US \$1,05 bilhão e o de ferro gusa a carvão vegetal por US\$1,65 bilhões.

No que diz respeito exclusivamente à área de florestas plantadas, pode-se verificar no Gráfico 11 que em 2014 a área brasileira de plantios de Eucalyptus e 
Pinus atingiu 7,15 milhões de hectares, maior índice durante o período analisado, tendo um crescimento de $1,54 \%$ em relação ao ano anterior. Os plantios de Eucalyptus representaram $77,8 \%$ da área total e os plantios de Pinus, $22,2 \%$.

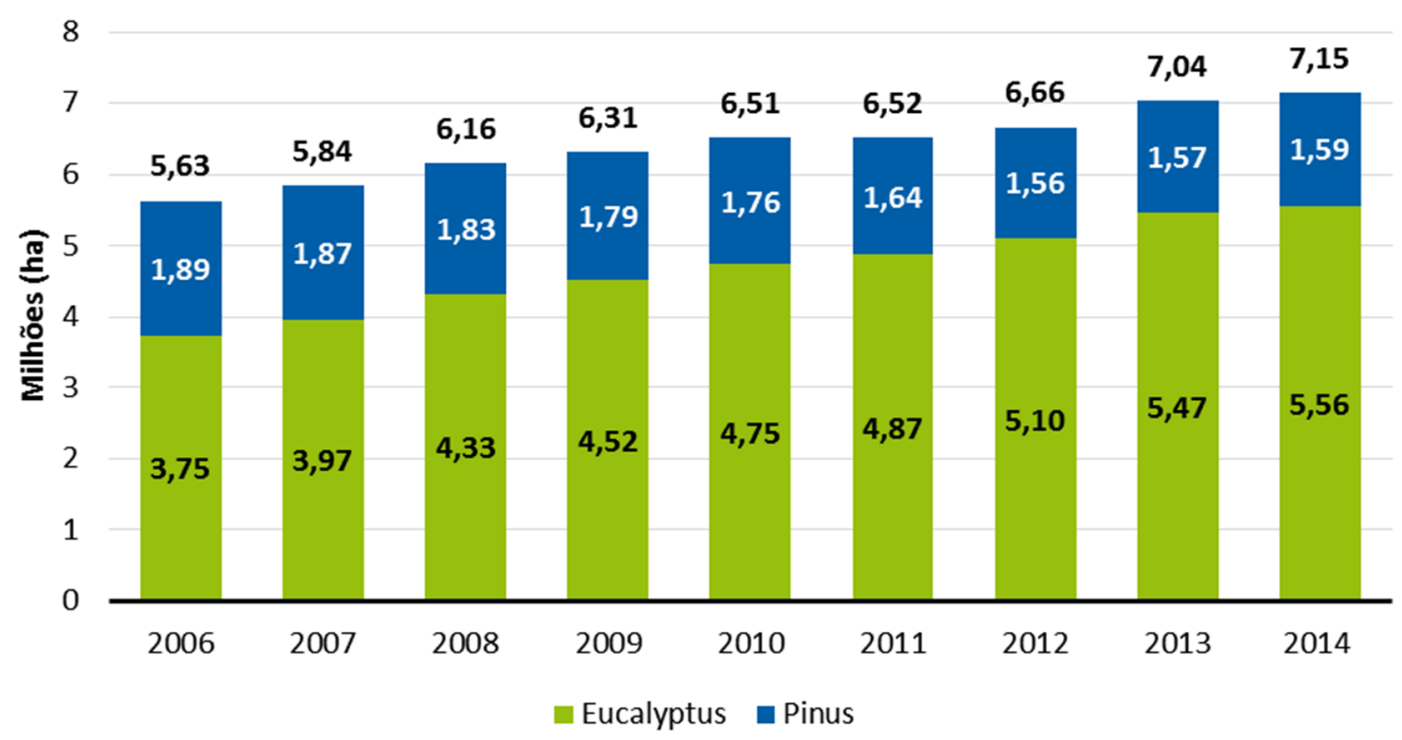

Gráfico 11 - Área de plantios florestais no Brasil por espécie, 2006-2014 Fonte: Adaptado de ABRAF (2013) e SISFLOR (2015)

Neste mesmo ano, a área de plantio de Eucalyptus totalizou 5.558.653 ha, representando um crescimento de 1,53\% (85.477 ha) frente ao indicador de 2013. Segundo a ABRAF (2013), o principal fator que alavancou esse crescimento foi o estabelecimento de novos plantios frente à demanda futura dos projetos industriais do segmento de papel e celulose. Em contrapartida, a área de plantio de Pinus totalizou 1.588.997 ha em 2014, valor 1,59\% superior ao registrado em 2013. Contudo, percebe-se uma constante redução na área plantada de Pinus, o que corrobora a tendência de redução de tal área em prol da substituição por plantios de Eucalyptus. Analisando o período 2006 a 2014, o aumento da área ocupada por Eucalyptus foi de 1.812 .859 ha $(32,61 \%)$ e a redução da área ocupada por Pinus foi de 297.289 ha $(-18,71 \%)$.

O Gráfico 12 ilustra a afirmação acima, onde percebe-se um aumento na porcentagem de florestas de Eucalyptus em relação às de Pinus entre 2006 e 2014. 


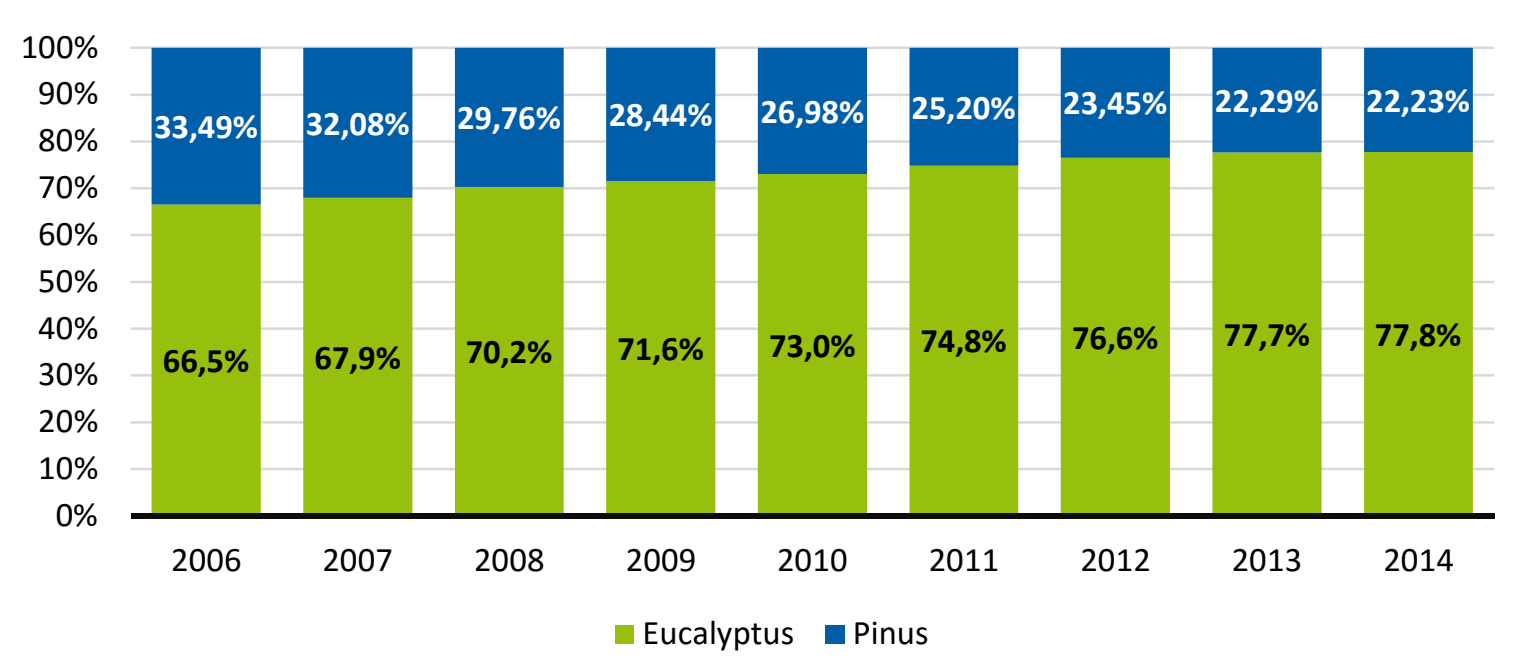

Gráfico 12 - Porcentagem de florestas de Eucalyptus e Pinus no Brasil Fonte: Adaptado de ABRAF (2013) e SISFLOR (2015)

Nota-se que o Eucalyptus possui uma larga predominância em relação ao Pinus durante todo o período analisado, contando um acréscimo contínuo porcentagem de florestas com esse gênero.

Os Estados com a maior concentração de plantios florestais em 2012 foram Minas Gerais e São Paulo, com 1.438.971 ha e 1.041.695 ha de florestas de Eucalyptus, respectivamente. Pode-se afirmar também que a maior concentração de plantios florestais ocorre nas regiões Sul e Sudeste do país (72,3\%), fato que se justifica em função da localização das principais unidades industriais dos segmentos de celulose e papel, painéis de madeira industrializada, siderurgia a carvão vegetal e madeira mecanicamente processada (ABRAF, 2013).

\subsection{PRODUÇÃO E CONSUMO DE MADEIRA PROVENIENTE DE FLORESTAS PLANTADAS}

O setor nacional de florestas plantadas é estratégico no fornecimento de matéria-prima e produtos tanto para o mercado interno quando para exportações.

A Figura 13 mostra a distribuição proporcional do consumo de madeira de Pinus e Eucalyptus produzida em 2012 pelos principais segmentos florestais, assim como o destino dos produtos gerados em relação aos mercados internos e externos. 


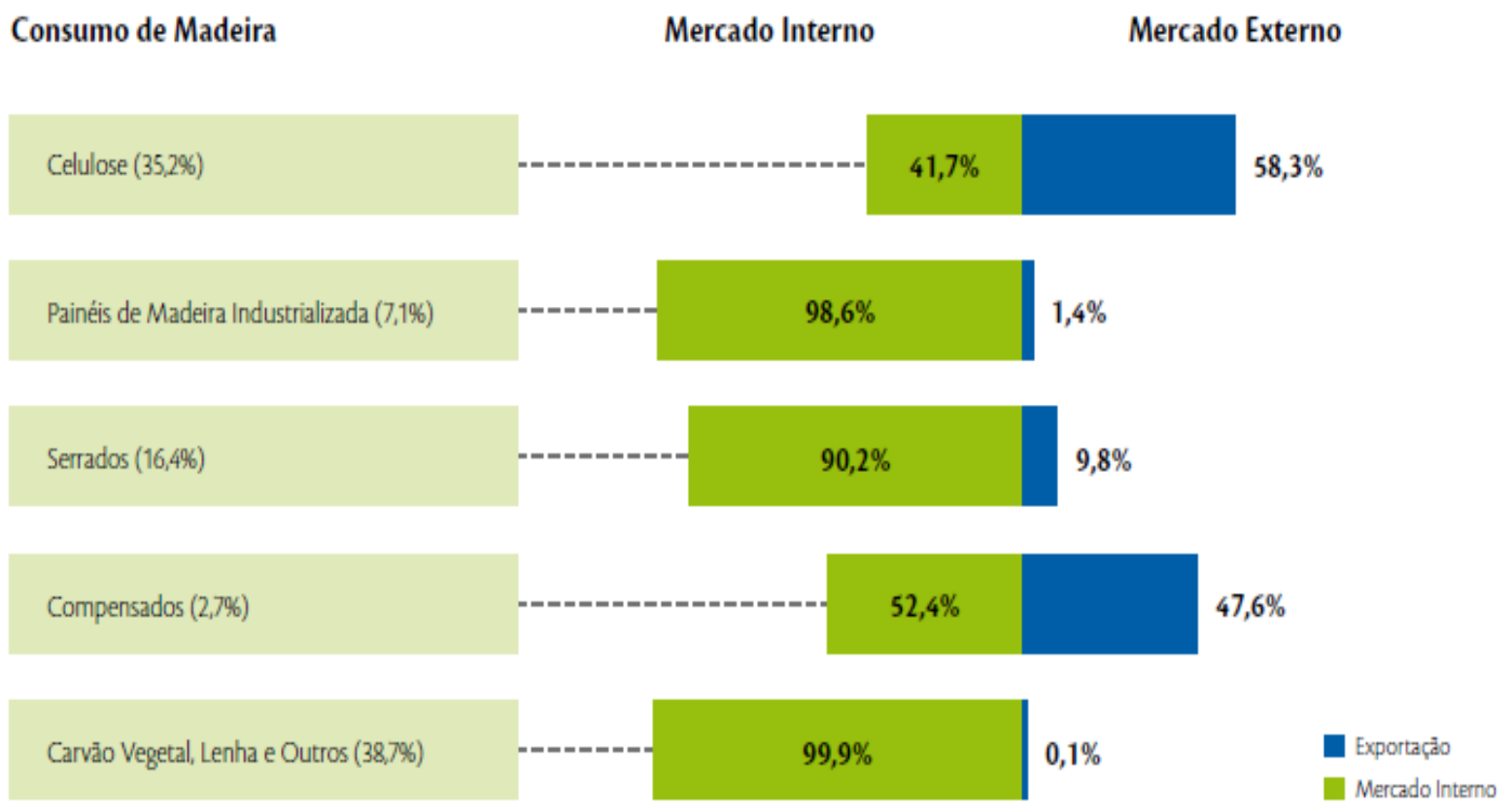

Figura 13 - Distribuição proporcional do consumo de madeira de florestas plantadas e do destino da produção - 2012

Fonte: ABRAF (2013)

Ressalta-se que, boa parte dos produtos das indústrias de processamento terciários (móveis, papel, pisos, molduras, etc.) também é exportada, o que demostra a importância do mercado internacional para o setor florestal brasileiro (ABRAF, 2013).

Nota-se que a utilização de madeira para a produção de carvão vegetal, lenha e outros, ainda conta com o maior percentual de destino de madeira extraída.

O Gráfico 13 apresenta um parâmetro geral a respeito da extração anual madeireira proveniente de florestas plantadas destinadas a combustíveis e uso industrial. 


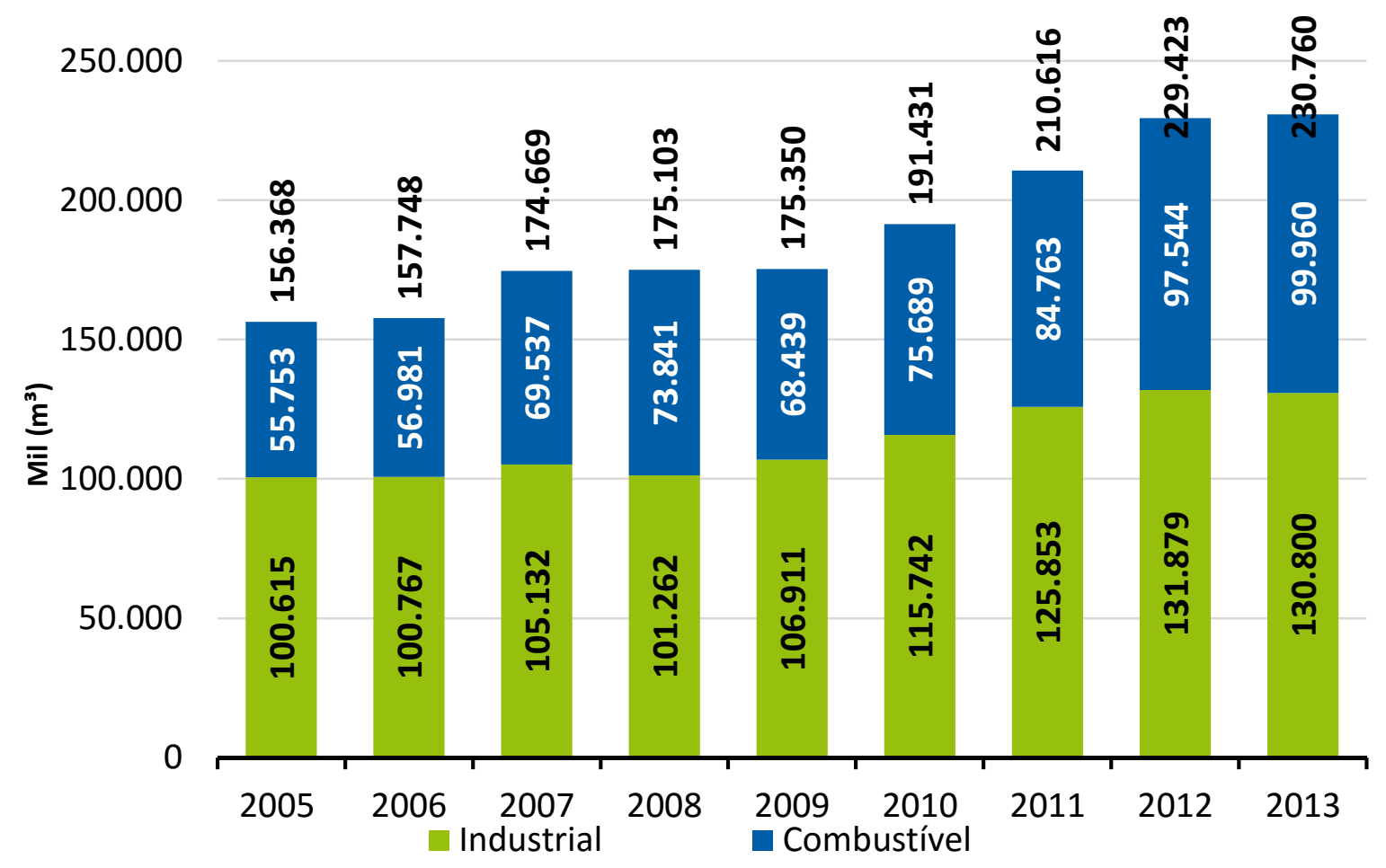

Gráfico 13 - Extração anual madeireira proveniente de florestas plantadas Fonte: Adaptado de ABRAF (2013) e SISFLOR (2015)

Percebe-se, ao longo do período analisado, uma tendência constante de crescimento da oferta de madeira, demonstrado pelos valores referentes à extração além da crescente demanda para sua utilização como combustível e destinada ao setor industrial, tendo este último um percentual sempre superior ao do ano anterior, exceto no índice de 2009 para 2008, comprovando sua eficiência para tal fim.

Os Gráfico 14 aGráfico 19 apresentam, respectivamente, os valores da produção e consumo interno dos principais produtos florestais em milhões de toneladas provenientes de florestas plantadas e destinados para combustível, como o carvão vegetal e para fins industriais, como celulose, papel, painéis industrializados, compensados e serrados. 


\section{Carvão Vegetal}

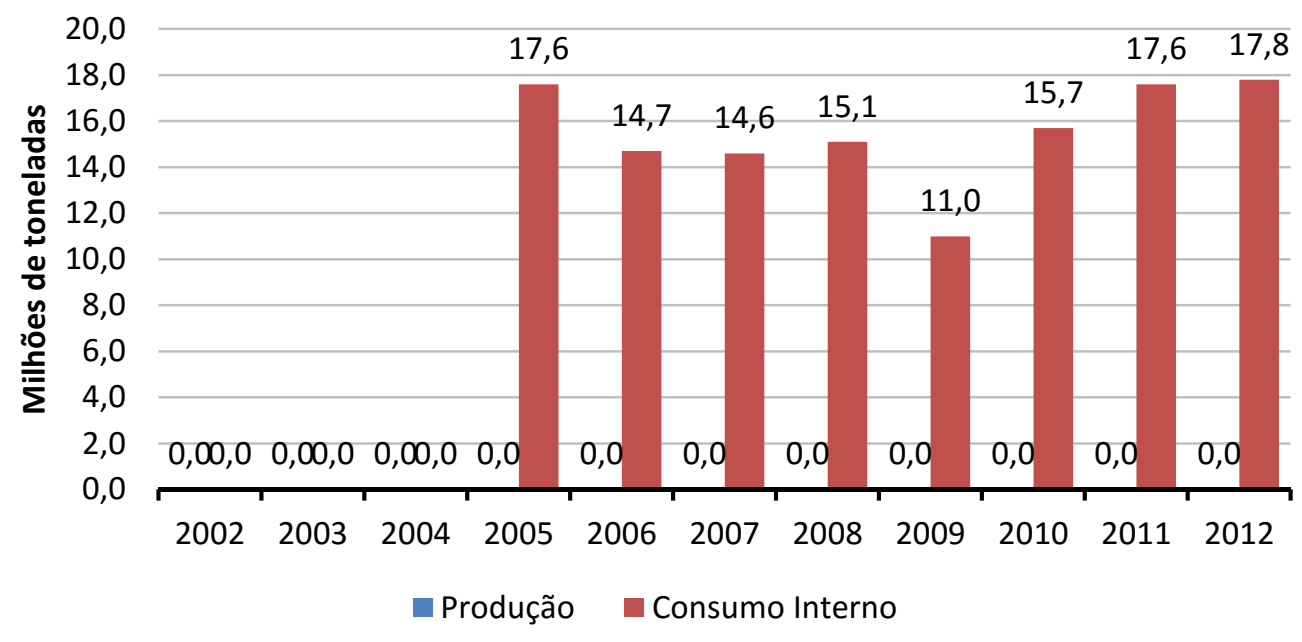

Gráfico 14 - Carvão Vegetal - Produção x Consumo Interno Fonte: Adaptado de ABRAF (2013)

O Gráfico 14 não apresenta valores de produção de carvão vegetal e somente valores de consumo a partir de 2005 devido a ausência de dados estatísticos.

O consumo de carvão vegetal exclusivamente de florestas plantadas teve um crescimento da ordem de 61,4\% entre 2009 e 2012. O aumento do consumo de carvão vegetal, em especial originado das florestas plantadas, ocorreu principalmente devido às exigências e a pressão constante dos grandes consumidores nacionais e internacionais de ferro-gusa para redução ou até eliminação da utilização de carvão proveniente de áreas nativas, aliado às exigências ambientais nacionais cada vez mais intensas, por meio de leis e regulamentos (ABRAF, 2013).

É importante salientar que o Brasil ainda é o único país que produz ferro-gusa a partir de carvão vegetal que, ao contrário do que ocorre com o coque siderúrgico, possui melhor qualidade e não contribui para a poluição ambiental, promovendo uma redução de emissões de gases de efeito estufa (ABRAF, 2013). 


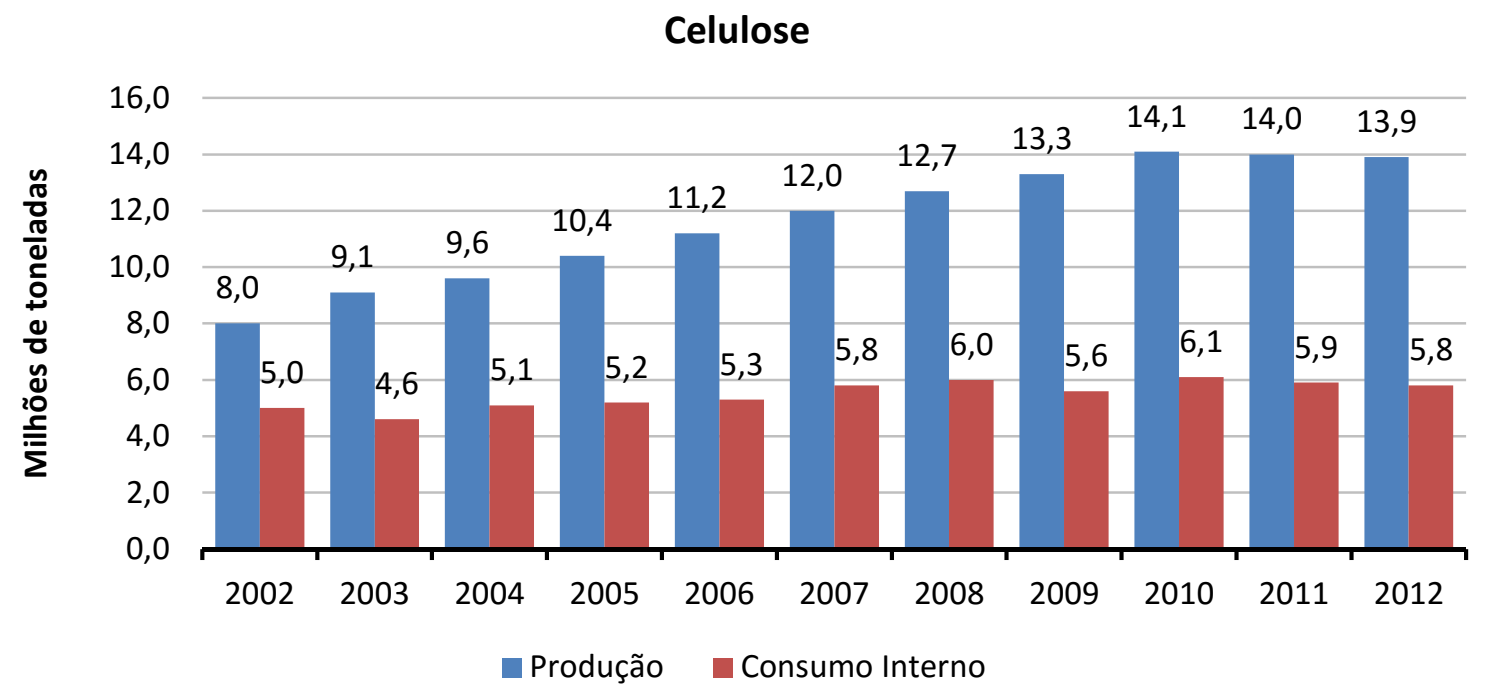

Gráfico 15 - Celulose - Produção x Consumo Interno

Fonte: Adaptado de ABRAF (2013)

Atualmente, o Brasil é o $3^{0}$ maior produtor mundial de celulose entre os produtores integrados, atrás apenas dos Estados Unidos e Canadá, e o 1ํe entre os produtores independentes. $O$ crescimento da produção de celulose é um reflexo do aumento das exportações para os mercados asiático e europeu (ABRAF, 2013).

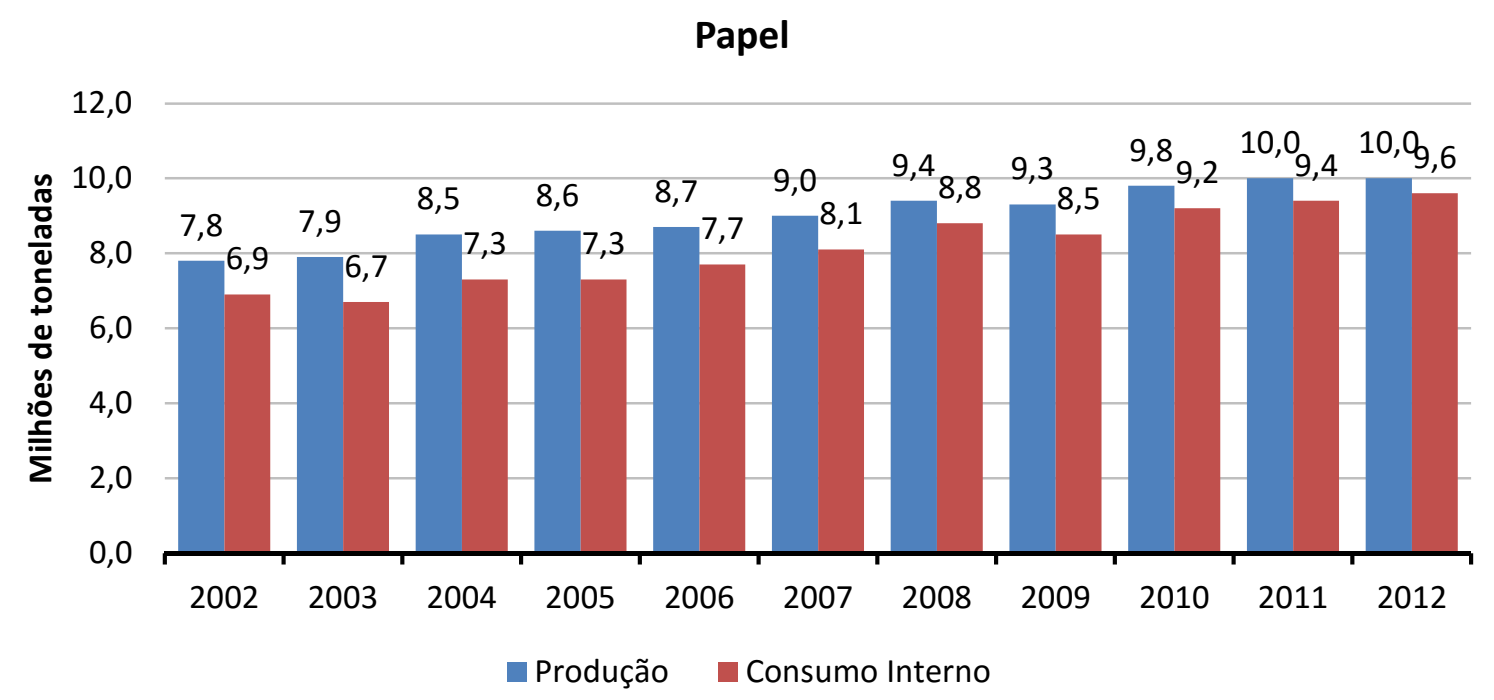

Gráfico 16 - Papel - Produção x Consumo Interno Fonte: Adaptado de ABRAF (2013)

A indústria nacional de papel ocupa a $9^{\underline{a}}$ posição no ranking internacional dos maiores produtores. Os principais produtos desse segmento compõem o mercado de embalagens, de produtos de higiene e beleza e de papéis para imprimir e 
escrever. O crescimento da indústria de papel ao longo do período analisado se deu em função do aumento da demanda interna e externa (ABRAF, 2013).

\section{Painéis Industrializados}

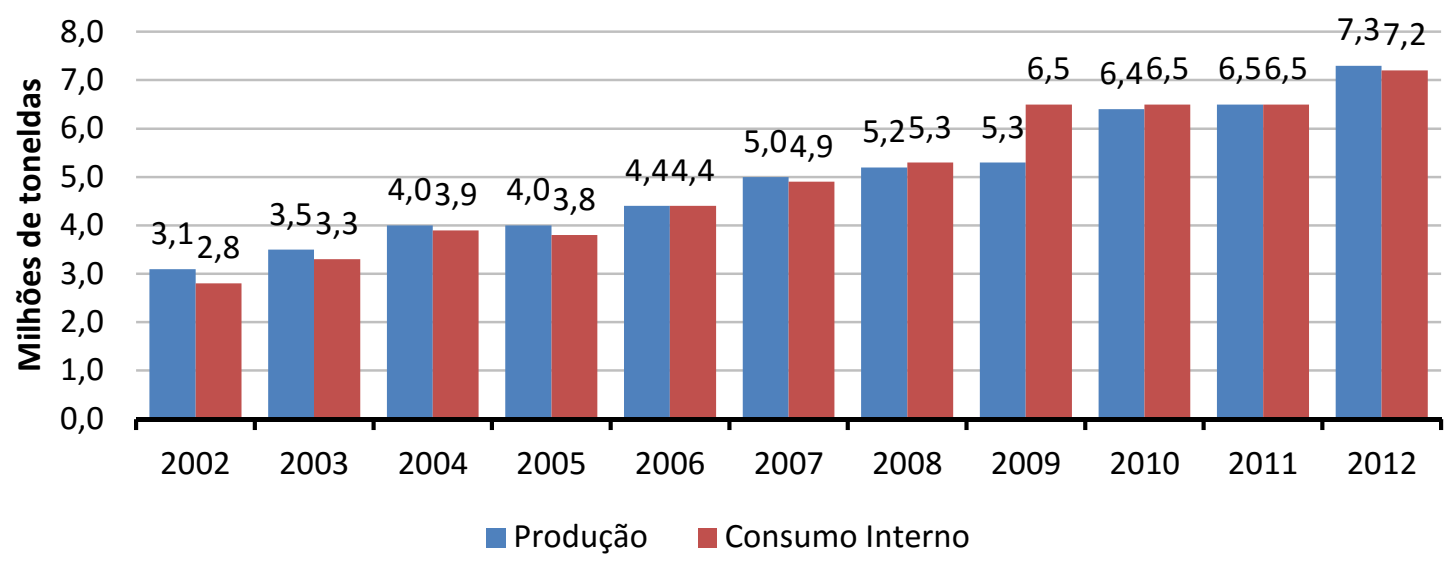

Gráfico 17 - Painéis Industrializados - Produção x Consumo Interno Fonte: Adaptado de ABRAF (2013)

\section{Compensados}

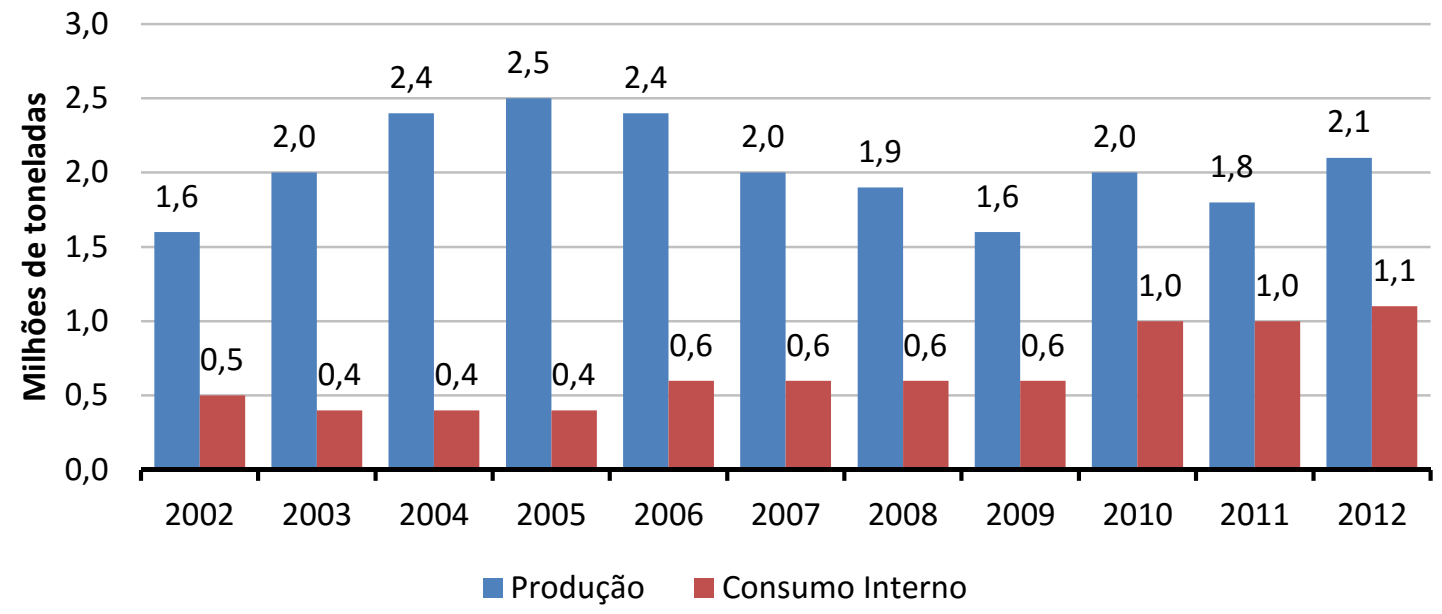

Gráfico 18 - Compensados - Produção x Consumo Interno Fonte: Adaptado de ABRAF (2013)

O setor de painéis de madeira industrializada é formado pelas indústrias produtoras de painéis de $\mathrm{MDP}^{39}, \mathrm{MDF}^{40}, \mathrm{OSB}^{41}$ e chapas de fibra. As indústrias desse segmento são importantes fornecedoras de matéria-prima para as indústrias de móveis, construção civil e embalagens.

\footnotetext{
39 Acrônimo da expressão da língua inglesa "Medium Density Particleboard"

${ }^{40}$ Acrônimo da expressão da língua inglesa "Medium Density Fiberboard"

41 Acrônimo da expressão da língua inglesa "Oriented Strand Board"
} 
O mercado de painéis de madeira industrializada encontra-se em expansão no Brasil, notando-se que o consumo anual de painéis industrializados cresceu de 2,8 milhões de toneladas em 2002 para 7,2 milhões em 2012, sendo que neste último ano a produção cresceu 12,3\% e o consumo 10,8\% em relação a 2011 . Segundo a ABRAF (2013), o desenvolvimento do setor se deu pela constante substituição do uso de compensados pelos painéis de madeira industrializada na produção moveleira, devido ao cenário econômico interno, onde o aumento da renda e o crescimento da construção civil são fatores que impulsionam o mercado imobiliário e o consumo de bens duráveis, implicando consequentemente no aumento da demanda das indústrias.

Mesmo com substituição dos compensados pelos painéis industrializados, no período analisado, a produção de compensados aumentou de 1,6 milhões de $\mathrm{m}^{3}$ anuais em 2002 para 2,1 milhões de $\mathrm{m}^{3}$ anuais em 2012. No mesmo período, o consumo evoluiu de 0,5 para 1,1 milhões de $\mathrm{m}^{3}$ anuais, sendo que em 2012 a produção de compensados totalizou um volume $16,7 \%$ superior ao volume produzido em 2011 e o consumo, um valor $10,0 \%$ superior.

$O$ crescimento do consumo de laminados e compensados sofre relevante impacto da demanda externa. A recuperação da demanda internacional, principalmente europeia, é fator fundamental para a recuperação do setor (ABRAF, 2013).

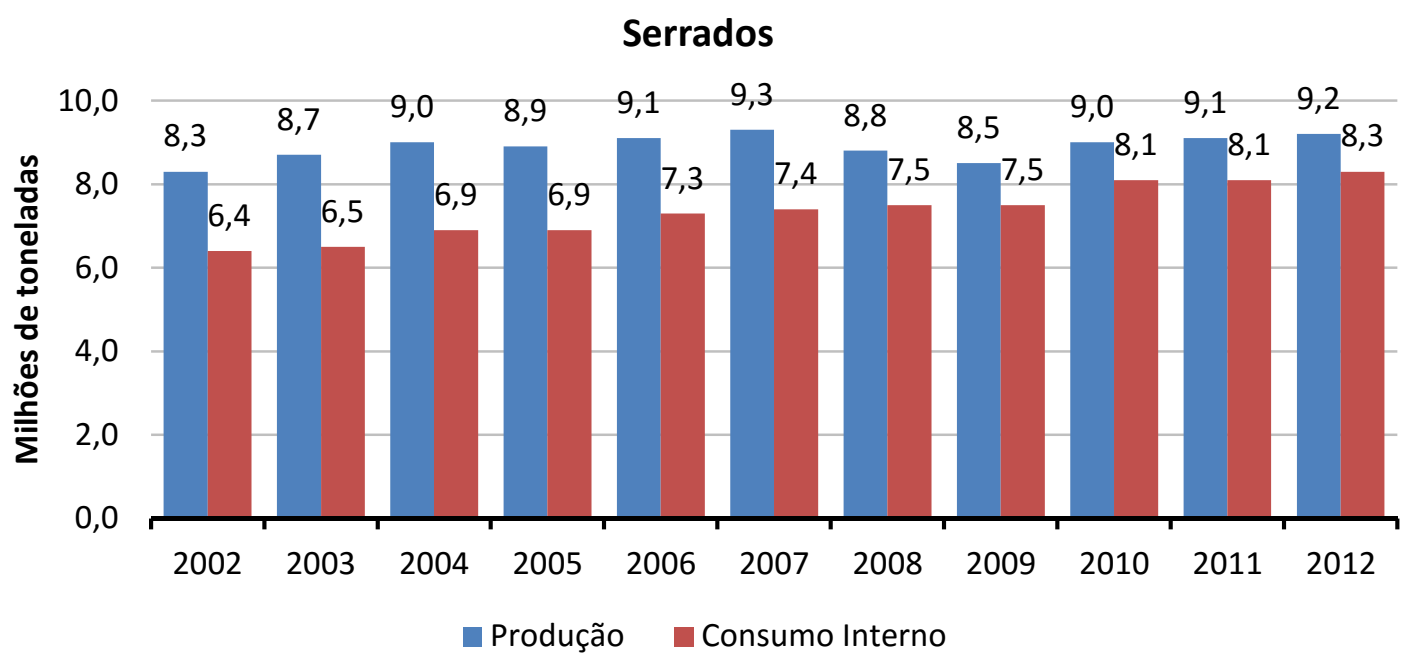

Gráfico 19 - Serrados - Produção x Consumo Interno Fonte: Adaptado de ABRAF (2013) 
A produção de serrados ${ }^{42}$ teve um aumento no período analisado de 8,3 milhões de $\mathrm{m}^{3}$ anuais para 9,2 milhões de $\mathrm{m}^{3}$ e o consumo de 6,4 milhões de $\mathrm{m}^{3}$ para 8,3 milhões de $\mathrm{m}^{3}$ anuais, sendo que, em 2012, a produção de serrados totalizou um volume $1,1 \%$ superior ao volume produzido em 2011 e o consumo um valor $2,5 \%$ superior.

Nos últimos anos, o crescimento do consumo de madeira serrada foi influenciado principalmente pelo desenvolvimento do mercado interno, estimulado pelo crescimento da indústria da construção civil e do mercado de embalagens (ABRAF, 2013).

Após a análise dos dados apresentados pode-se constatar um aumento na demanda por madeira oriunda de florestas plantadas, justificada também pela intensa exploração econômica que tem causado diminuição do estoque de madeiras nativas provenientes da Amazônia, incluindo aquelas de alta durabilidade natural destinadas a usos em contato com o solo. A escassez dessas madeiras resulta na elevação do preço, inviabilizando economicamente seu uso (ARAÚJO; MAGALHÃES; OLIVEIRA, 2012).

\subsection{EMISSÕES DE CARBONO E ENERGIA INCORPORADA}

De acordo com Punhagui (2014), os resíduos são os principais agentes emissores de dióxido de carbono, sendo eles responsáveis por $97 \%$ a $99 \%$ das emissões no sistema de fabricação de produtos para a madeira nativa e 88\% a 99\% para a madeira plantada.

A autora destaca que uma tonelada seca de madeira serrada nativa na porta do consumidor emite de 5.135 a $44.394 \mathrm{kgCO}_{2}$, enquanto que de madeira plantada emite de 41 a $726 \mathrm{kgCO}_{2}$. Isto se deve à grande quantidade de resíduos produzidos na extração, que são considerados reserva de carbono que se subtrai da floresta tropical.

\footnotetext{
42 De acordo com Souza et al. (2007 apud Punhagui 2014. p. 192), o rendimento do desdobro do Eucalyptus para a produção de madeira serrada bruta foi entre $37 \%$ e $38 \%$ e a produção de resíduos entre $62 \%$ e $63 \%$.

SOUZA, A. N., OliveiRA, A. D., SOlforo, J. R. S., MELlO, J. M., CARVALHO, L. M. T. Modelagem do rendimento no desdobro de toras de eucalipto cultivado em sistema agroflorestal, Cerne, vol. 13, № 2, p. 222238, jun. 2007.
} 
Tal afirmação pode ser comprovada quando se analisa os dados levantados pela autora referente às emissões de $\mathrm{CO}_{2}$ da madeira na porta das unidades industriais, desconsiderando o transporte ao consumidor, onde uma tonelada de madeira nativa emite de 5.017 a $44.382 \mathrm{kgCO}_{2} \mathrm{e}$ a madeira serrada plantada de $32 \mathrm{a}$ $559 \mathrm{kgCO}_{2}$.

Pode-se constatar uma redução, considerando os valores máximos apresentados, de aproximadamente $30 \%$ para a madeira plantada, enquanto que para a madeira nativa os valores permanecem praticamente os mesmos.

Isto ressalta os resultados obtidos pela autora, que no sistema plantado, grande parte das emissões estão concentradas no transporte para o consumidor, com média de $34 \%$ das emissões devido ao fornecimento não ser somente para o principal mercado consumidor, localizado na região Sudeste, mas também para todas as outras regiões do Brasil, enquanto que no sistema nativo, a maior parte está na extração $(\mathrm{PE}+\mathrm{E})$, devido ao volume considerado da geração de resíduos, entre 1,4 e 4,8 toneladas de biomassa destruída por tonelada de tronco extraído.

O Gráfico 20 apresenta as porcentagens de emissão de $\mathrm{CO}_{2}$ em todas as etapas do processo analisado.
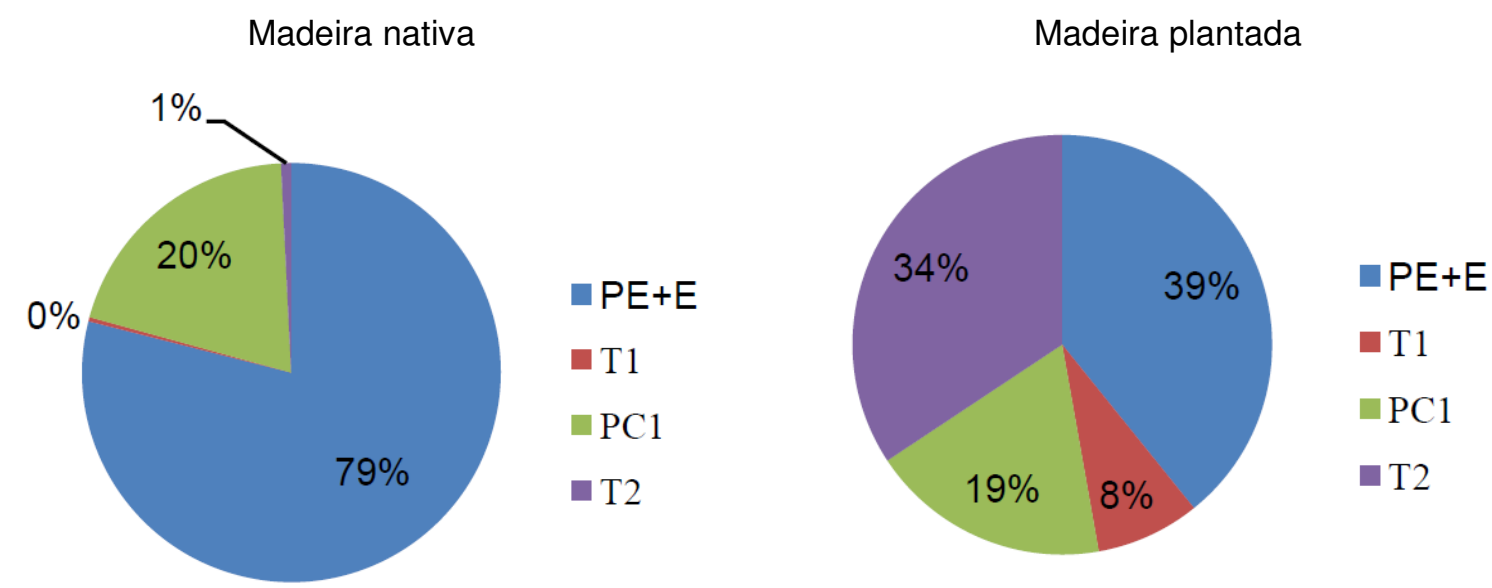

Legenda: $\mathrm{PE}+\mathrm{E}$ = pré extração e extração; $\mathrm{T} 1$ = transporte da floresta/plantação até o processamento $1 ; \mathrm{PC} 1=$ processamento $1 ; \mathrm{T} 2$ = transporte até o consumidor

Gráfico 20 - Distribuição percentual das emissões de $\mathrm{CO}_{2}$ em cada fase do processo da cadeia produtiva Fonte: Punhagui (2014)

A energia incorporada na madeira plantada serrada, na porta do consumidor, varia de 945 a $15.451 \mathrm{MJ} / \mathrm{t}$, sendo que os valores mais altos se referem aos produtos secos em estufa, prática muito comum, devido ao fato da madeira ser menos densa e, consequentemente, mais suscitivel a ataques de fungos e cupins. 
$\mathrm{Na}$ madeira nativa serrada, a energia incorporada varia de 948 a $5.357 \mathrm{MJ} / \mathrm{t}$, justamente pelo fato da prática de secagem ser menos comum que na madeira plantada (PUNHAGUI, 2014).

Pode-se constatar o fato de que o processo de secagem é o que confere uma grande quantidade de energia incorporada à madeira plantada quando se compara os valores acima com os encontrados pela autora com o material na porta das indústrias, pois os valores são reduzidos para aproximadamente $7.868 \mathrm{MJ} / \mathrm{t}$ de madeira plantada e de 786 a $3.307 \mathrm{MJ} / \mathrm{t}$ para a madeira nativa. Mesmo desconsiderando o transporte até o consumidor, o valor para a madeira plantada ainda é superior ao encontrado para a madeira nativa na porta do consumidor.

O Gráfico 21 apresenta as porcentagens de energia incorporada em todas as etapas do processo analisado.

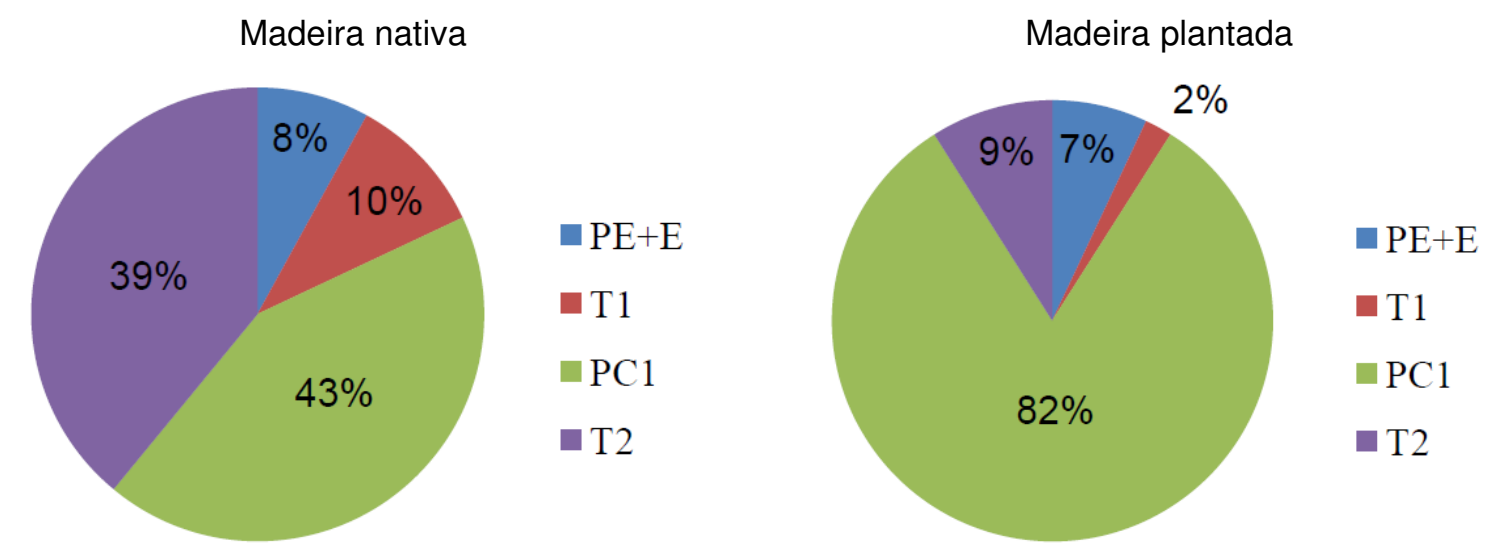

Legenda: $\mathrm{PE}+\mathrm{E}$ = pré extração e extração; $\mathrm{T} 1$ = transporte da floresta/plantação até o processamento $1 ; \mathrm{PC} 1=$ processamento $1 ; \mathrm{T} 2$ = transporte até o consumidor

Gráfico 21 - Distribuição percentual da energia utilizada em cada fase do processo da cadeia produtiva Fonte: Punhagui (2014)

\subsection{TRATAMENTO PRESERVATIVO EM MADEIRAS ORIUNDAS DE FLORESTAS PLANTADAS}

A madeira é um material natural, e como tal, degrada-se de forma distinta de materiais como o concreto ou como o aço (MARTINS, 2010). Em razão de sua estrutura anatômica e composição química, é fonte de alimento para vários organismos xilófagos, sendo os fungos apodrecedores os maiores decompositores da madeira (RAMOS et al., 2006). 
De acordo com Yuba et al. (2003), um dos fatores desfavoráveis para a utilização de madeira de florestas plantadas é a necessidade do uso de produtos químicos tóxicos para sua preservação, sendo que o uso de tais produtos pode ser considerado indicador da dimensão ambiental da sustentabilidade nas construções onde são empregadas esse tipo de madeira.

A madeira tratada é o produto resultante da preservação da madeira por meio de vácuo-pressão com o intuito de controlar agentes biológicos, físicos e químicos, tais como chuva, sol e parasitas, que podem afetar a durabilidade da madeira (ABRAF, 2013).

Segundo a ABRAF (2013), a madeira tratada vem ganhando mercado nas mais diversas regiões do país nos últimos anos. As principais usinas de preservação de madeira estão distribuídas predominantemente nas Regiões Sudeste e Sul, onde se concentram as maiores áreas reflorestadas do país.

Contudo, pode-se afirmar que no Brasil o tratamento químico de madeira não é muito comum, visto que em 2012, a produção de madeira tratada com preservativos foi de apenas 1,6 milhões de $\mathrm{m}^{3}$ (ABRAF, 2013), valor muito inferior ao da extração de madeireira proveniente de florestas plantadas de $229.423 .000 \mathrm{~m}^{3}$, ou seja, um percentual aproximado de apenas $0,7 \%$.

A atividade é regulamentada por legislações específicas e orientada por normas da Associação Brasileira de Normas Técnicas (ABNT), dentre elas a norma ABNT NBR 16143:2013 - Preservação de madeiras - Sistema de categorias de uso. Esta Norma estabelece um sistema de categorias de uso para madeiras, com foco no tratamento preservativo para aumento da durabilidade dos sistemas construtivos.

A utilização de espécies plantadas, de rápido crescimento, tratadas com preservativos é uma alternativa para a substituição do uso de madeira de espécies nativas, que possuem uma maior durabilidade natural. As espécies plantadas necessitam receber tratamento químico adequado para sua utilização, a fim de se prolongar a vida útil dos componentes evitando ataques de fungos e insetos, o que garante uma economia de árvores utilizadas na construção e manutenção de bens produzidos com esse material. Segundo Lepage ${ }^{43}$ (1986 apud INO, 1992. p. 48), a finalidade pretendida da utilização da madeira é que define o tipo e o processo de

43 LEPAGE, E. S. Manual de preservação de Madeiras. Instituto de Pesquisas Tecnológicas do Estado de São Paulo, IPT, v.1 e v.2. 1986. 
tratamento preservativo adequado, dentre eles os tratamentos industriais até os caseiros, de manuseio simples.

A eficiência do tratamento é medida de acordo com seu grau de toxidez, sendo que quanto mais tóxico melhor a proteção contra $o$ ataque de fungos $e$ insetos, contudo, deve-se ter cuidado com a saúde do ser humano durante seu manuseio e sua utilização. A adoção do processo de preservação e o tipo de produto a ser utilizado dependem da análise de variáveis como: a espécie de madeira, condições de uso, destino da obra, custos envolvidos, disponibilidade de equipamento dentre outros. Normalmente, os preservativos são divididos em oleossolúveis e hidrossolúveis, sendo os últimos citados os mais comumente utilizados no Brasil.

Segundo o Boletim Técnico - divisão Osmose da Montana Química (2010), desde 1930 o preservativo hidrossolúvel Arseniato de Cobre Cromatado (CCA) vem sendo usado em quantidades crescentes pela indústria de preservação de madeira, sendo que até hoje já foram tratados aproximadamente $400.000 .000 \mathrm{de}^{3}$ de madeira com CCA. Devido a esse fato, a partir da década de 70, estudos vêm sendo desenvolvidos no intuito de se chegar à uma formulação que otimize eficiência na proteção da madeira contra os organismos xilófagos (fungos, insetos, brocas marinhas) com fixação dos seus componentes metálicos nos constituintes do lenho (celulose, hemiceluloses e lignina), de forma a garantir a menor lixiviação possível como fator de segurança para o meio ambiente e para a saúde humana.

Segundo Moreschi (2005), embora muitas pesquisas comprovem não haver riscos de contaminação de solo por lixiviação deste elemento químico, a sua valorização ainda é encarada com preocupação.

O CCA possui uso regulado e proibido em muitos países da Europa e América do Norte (APPEL ${ }^{44}, 2007$ apud PUNHAGUI, 2014. p. 46) devido a seu potencial de contaminação da água e do solo, por prejudicar a saúde da população que se encontra em contato com o produto. O tratamento químico, apesar de prolongar a vida útil do produto, apresenta alguns riscos, como a contaminação de

\footnotetext{
${ }^{44}$ APPEL, J. S. L., TERESCOVA, V., RODRIGUES, V. C. B., VARGAS, V. M. F. Aspectos toxicológicos do preservativo de madeira CCA (arseniato de cobre cromatado): revisão, Revista Brasileira de Toxicologia, vol. 19, no 1 , p. 33-47, 2007.
} 
solos e águas por lixiviação ${ }^{45}$ e seres vivos por sua toxidade, o aumento do custo do produto e a diminuição das possibilidades de reciclagem. Contudo, segundo Brazolin et. al. (2003), os acabamentos aplicados sobre a madeira como "stains" e resinas hidrorrepelentes podem reduzir sensivelmente a lixiviação.

Uma alternativa à utilização do CCA é o Borato de Cobre Cromatado (CCB), com menor toxidade devido à substituição do arsênio pelo boro, tendo o cobre como agente fungicida e o boro, inseticida. O CCB começou a ser comercializado na Alemanha no início da década de 1960 com o nome de "Wolmanit CB" (LEPAGE46, 1986; RICHARDSON ${ }^{47}, 1993$ apud RAMOS et al., 2006).

Um fator importante a ser considerado é que, ao se reduzir o uso de produtos preservadores, a sustentabilidade ambiental é maior. Contudo, se for aumentada a durabilidade da madeira, também é favorecida a sustentabilidade (YUBA et al., 2003). Segundo Lorenz ${ }^{48}$ (2008) apud Agopyan e John (2011), "não existe sustentabilidade sem durabilidade", pois a mesma influencia decisivamente o período de tempo em que a construção vai prestar serviços e a quantidade de recursos na manutenção (AGOPYAN e JOHN, 2011).

Toda a madeira preservada tem um ciclo de vida que, uma vez cumprido, deixa como alternativa: reutilização ou destinação final.

Tendo em vista que a madeira tratada em autoclave possui uma durabilidade garantida de 30 anos, mesmo em condições severas de exposição (INO et al., 1998), o problema da destinação final pode ser amenizado com a possibilidade de

\footnotetext{
45 Em um estudo realizado no Brasil verificou-se que, após cerca de trinta anos de exposição de amostras de madeira tratada com CCA e CCB, a poluição do solo para aquelas com uma maior retenção do preservativo (11 $\mathrm{kg} / \mathrm{m}^{3}$ ) estavam abaixo esses padrões de qualidade e taxas fixadas pela Companhia Ambiental do Estado de São Paulo - CETESB que é considerado sem contaminação (JANKOWSKY et al., 2012a apud PUNHAGUI, 2014. p. 208). Além disso, o mesmo autor, em outro estudo conclui que a taxa de decomposição tem uma relação direta com o nível de retenção utilizado nas amostras tratadas com CCA-C e a menor taxa de decomposição (maior expectativa de durabilidade, mais de sessenta anos) corresponde a tratamentos com CCA$\mathrm{C}$ em retenções acima de $8,0 \mathrm{~kg} / \mathrm{m}^{3}$ (JANKOWSKY et al., 2012b apud PUNHAGUI, 2014. p. 208).
}

JANKOWSKY, I. P., LEPAGE, E. S., SALVELA, C., VIDAL, J. M. Soil accumulation of CCA and CCB active ingredients measured inside a stake field test [Conference Poster], apresentado em 2012, IUFRO Conference Division 5 Forest Products, Lisboa, Portugal, p. PP089, 2012a

JANKOWSKY, I. P., LEPAGE, E. S., SALVELA, C., VIDAL, J. M., TAKESHITA, S. Effectiveness of CCA-C and CCB preservatives after a 30 years stake test, Suécia, Section 3 Wood protecting chemicals IRG/WP 12-30606, 2012b.

46 LEPAGE, E.S. Preservativos e sistemas preservativos. In: LEPAGE, E.S. (Coord.). Manual de preservação de Madeiras. São Paulo: IPT, 1986. v. 1. p. 279-342.

47 RICHARDSON, B.A. Wood preservation. 2. ed. London: E \& FN SPON, 1993. 226p.

${ }^{48}$ LORENZ, E. We cannot have sustainability without durability. PCI Journal. 2008. 
não transformá-la em resíduo, mas sim em um produto reciclável (CUNHA; CÉSAR, 2004).

Os mesmos autores destacam que com um bom projeto arquitetônico, a madeira de floresta plantada pode ser empregada através de elementos estruturais e construtivos que possam ser desmontados e reutilizados em outras construções ou mesmo em outros processos de transformação para gerarem novos produtos de construção.

Como alternativas de reutilização destaca-se a reciclagem para fabricação de chapas de fibras, chapas de partículas, madeira laminada, compósitos de madeiracimento e de fibras de madeira-plástico, destinadas ao mobiliário de uso externo, caixas de lixo, de plantas, decks, cavaletes, parapeitos e pellets. Já no que diz respeito à destinação final como resíduo, a madeira pode ser descartada em aterros industriais controlados; ser incinerada, desde que seja adotado um adequado sistema de limpeza de gases para controle das emissões, capaz de atender a legislação ambiental vigente; ou passar por um processo termoquímico que combina temperatura e pressão chamado Chartherm, desenvolvido pela companhia Thermya (Bordeaux, França).

Este processo é basicamente um "sistema de reciclagem de resíduos de madeira", capaz de operar com todos os resíduos de madeira contaminada com qualquer tipo de produto tóxico bem como seus níveis de concentração. Isto significa que o processo Chartherm é capaz de reciclar a madeira mesmo que ela esteja contaminada com diversas substâncias tóxicas, como os tratamentos com CCA e creosotos. O processo Chartherm é um sistema de reciclagem de resíduos de madeira que não requer uma triagem prévia para classificar a madeira por tipo de contaminação. Ele também não requer uma retirada prévia de eventuais inclusões metálicas presentes na madeira (CCA Reserach Homepage, 2016).

O processo Chartherm possui três estágios principais: esmagamento da madeira; conversão termoquímica ("charterização") e; separação (por refinação), tendo como objetivo recuperar os metais, o carbono e a energia contida em resíduos 
de madeira tratada com CCA, sendo identificado como um candidato para a melhor tecnologia disponível (HELSEN; VAN DEN BULCK ${ }^{49}, 2005$ apud HELSEN, 2008).

Uma possível alternativa de tratamento para as peças serradas de Eucalyptus utilizadas nas interfaces estruturais propostas no presente trabalho é o pincelamento, visto que o tratamento preservativo em autoclave não atinge o cerne a tora de madeira deste gênero.

Este tipo de tratamento se trata de um procedimento simples, aparentemente sem necessidade de maiores preocupações, senão a de aplicar um produto preservativo líquido ou dissolvido em algum tipo de solvente, na superfície da peça que se pretende tratar, objetivando o unicamente a proteção superficial (MORESCHI, 2013).

Em decorrência do futuro aparecimento de fendas nas peças de madeira, uma região interna, não preservada, é exposta à agentes xilófagos, sendo necessário novo pincelamento de produto preservativo, sendo este segundo tratamento é tão importante quanto o tratamento inicial.

Deve-se levar em consideração, segundo Moreschi (2013), a aplicação de maiores quantidades de soluções proporcionalmente à espessura da camada de madeira a ser tratada e sua distribuição de forma homogênea sobre a superfície da peça em camadas sucessivas.

Um fato importante a se considerar é que no Brasil não há dados oficiais disponíveis sobre as zonas que possuem risco de ataque de cupins (como nos Estados Unidos, mapeadas pelo US Forest Service), tornando a análise do grau de exposição e medidas preventivas dependentes da experiência de profissionais.

\footnotetext{
49 HELSEN, L., VAN DEN BULCK, E., 2005. Review of disposal technologies for chromated copper arsenate (CCA) treated wood waste, with detailed analyses of thermochemical conversion processes. Environmental Pollution 134, 301-314.
} 


\section{COORDENAÇÃO MODULAR E SISTEMAS CONSTRUTIVOS COM COMPONENTES PRÉ-FABRICADOS EM MADEIRA}

\subsection{COORDENAÇÃO MODULAR}

A construção civil é um segmento que tem muito a contribuir com o caráter sustentável na obtenção, gestão e utilização dos materiais, como por exemplo, buscando alternativas para o desperdício praticado nos canteiros de obra dos sistemas tradicionais de construção, que têm como características principais o elevado custo, lentidão no processo construtivo, desperdício de materiais e consequentemente a geração de resíduos. O combate ao desperdício se dá ainda durante o processo produtivo, pela adoção de tecnologias menos intensivas em energia e que requeiram menos matérias-primas.

$\mathrm{Na}$ construção de edificações que se utilizam da madeira como material construtivo, o aspecto custo é tão importante quanto na construção tradicional, mas possui vantagens devido à técnica aplicada à pré-fabricação de componentes e também aos procedimentos construtivos. Segundo Ino (1992), a solução comumente utilizada para a redução do custo sempre foi através da redução da qualidade, tanto no que diz respeito ao material utilizado quanto pela limitação da área construída.

Podem-se considerar também os seguintes aspectos para a redução dos custos: aspectos inerentes ao próprio projeto, com caráter modular, levando em consideração a disponibilidade comercial de seções e comprimentos de peças, 0 que facilita a montagem de componentes e reduz o desperdício e a geração de resíduos; aspectos referentes à escolha e seleção de peças, bem como materiais para interface de componentes, que por vezes apresenta um maior custo inicial, sendo absorvido com a redução dos custos de manutenção e durabilidade da edificação; aspectos referentes ao processo construtivo, pois devido à facilidade de montagem dos componentes e o uso de ferramentas simples, não requer mão-deobra extremamente qualificada.

Segundo Ino (1992), a coordenação modular é umas das mais importantes ferramentas para se alcançar a máxima racionalização, sendo um dos pontos chave para o sucesso da pré-fabricação, minimizando tanto desperdícios materiais quanto 
temporais, já indicando a necessidade do estabelecimento de normalização padronizada de materiais, componentes e elementos construtivos.

"Racionalização é um processo mental que governa a ação contra os desperdícios temporais e materiais dos processos produtivos, aplicando o raciocínio sistemático, lógico e resolutivo, isento de influxo emocional" (ROSSO50, 1980 apud INO, 1992. p. 87).

O sistema de coordenação modular tem como objetivo relacionar a dimensão dos materiais com as dimensões dos ambientes arquitetônicos, reduzindo 0 desperdício, aumentando o rendimento da mão-de-obra e reduzindo o prazo de execução mediante o uso de uma dimensão base, ou seja, o módulo com o qual se relacionam as dimensões dos materiais, para simplificar, sem desperdícios, as dimensões dos componentes de tal maneira que possam ser permutáveis, combinados e flexíveis.

No Brasil a NBR 15.873/2010 - Norma de Coordenação Modular para edificações, especifica como padrão a medida de $100 \mathrm{~mm}$ para módulos básicos, além de definir os termos e os princípios da coordenação modular para edificações. O conceito de coordenação se aplica ao projeto e construção de edificações de todos os tipos e também à produção de componentes construtivos.

Segundo a Associação Brasileira de Desenvolvimento Industrial (ABDI, 2009), a implantação da coordenação modular no país é um dos eixos centrais da Política de Desenvolvimento Produtivo (PDP) - Setorial da Construção Civil, sendo que a plena implantação da Norma Técnica de Coordenação Modular viabilizará a interoperabilidade técnica e permitirá:

- reduzir e dar coerência à variedade de medidas utilizadas na fabricação de componentes;

- simplificar a coordenação dimensional nos projetos das edificações, que hoje é elaborada caso a caso;

- simplificar o processo de marcação no canteiro de obras para posicionamento e montagem de componentes construtivos;

- reduzir cortes e ajustes de componentes e elementos construtivos e a geração de resíduos no canteiro de obras;

\footnotetext{
50 ROSSO, T. Racionalização na construção. São Paulo, FAU-USP, 300p, 1980.
} 
- aumentar a intercambiabilidade de componentes tanto na construção inicial quanto em reformas e melhorias ao longo da vida útil da edificação;

- evitar cortes e ajustes desnecessários;

- induzir maior cuidado na resolução de projetos e maior acuidade técnica na sua execução;

- ampliar a cooperação entre os diversos agentes da cadeia produtiva da construção e;

- minimizar desperdícios, com redução de custos e diminuição nos prazos de execução das obras, devido à maior facilidade de ajustes e montagens.

A expressão "coordenação modular" é familiar a muitas pessoas, mas, no entanto, é entendida como repetição de elementos construtivos, pré-fabricação, coordenação dimensional etc., o que contribui para a persistência de alguns preconceitos, como, por exemplo, a ideia de que a construção coordenada modularmente leva a uma monotonia do ambiente construído.

Pode-se dizer que a coordenação modular promove a compatibilidade dimensional entre elementos construtivos (definidos nos projetos das edificações) e componentes construtivos (definidos nos projetos de produtos), promovendo sua otimização através da possibilidade de pré-fabricação de componentes e elementos estruturais em unidades de pré-fabricação, o que permite um maior controle do processo e qualidade dos referidos componentes e consequentemente das edificações, pois diminui a execução de trabalhos realizados no canteiro de obra.

\subsection{SISTEMAS CONSTRUTIVOS COM COMPONENTES PRÉ-FABRICADOS EM MADEIRA}

Sistema construtivo em madeira pode ser definido, segundo Cunha e César (2004), como sendo a organização de componentes, elementos e sub-sistemas feitos em madeira e dispostos de modo a constituir uma edificação para abrigar atividades humanas. Os autores ressaltam que no processo de classificação dos sistemas, existem diversos critérios para agrupar as soluções construtivas, podendo ser os sistemas arranjados segundo o grau de industrialização da construção. 
Sobre a experiência de construção em madeira nos Países Andinos, a Junta Del Acuerdo de Cartagena (JUNAC, 1984) agrupa os sistemas construtivos em não industrializados (sistema vernacular e pré-cortado) e industrializados (sistema précortado, pré-fabricação parcial, em painéis e componentes e pré-fabricação total ou volumétrica) devido à quantidade de trabalho realizado na fábrica ou na obra, desde a transformação da madeira a peças de seções e tamanhos distintos até a fabricação completa de elementos volumétricos, tendo como características:

- Sistema vernacular: utiliza sistemas e materiais de construção tradicionais, sendo executado completamente no local da obra, com aplicação de pouca tecnologia moderna, assim como sistemas de transporte pesado, conferindo pouca transformação à matéria-prima.

- Sistema semi pré-cortado ou habilitado: as peças de madeira chegam ao canteiro de obra cortadas somente com as seções finais. Os corte nos comprimentos, rebaixos nas peças e perfurações são realizados na obra. Este sistema requer no canteiro, mão de obra semi-qualificada, capaz de utilizar ferramentas de carpintaria simples. Requer também documentação técnica tais como projeto, lista de peças e detalhes arquitetônicos.

- Sistema pré-cortado: considerado o método mais antigo de pré-fabricação e um dos mais populares. As peças chegam ao canteiro nas dimensões de uso final, tanto nas seções quanto nos comprimentos, incluindo também os rebaixos e recortes necessários. As peças devem receber identificação e serem agrupadas conforme 0 uso antes de serem transportadas para 0 canteiro. É um sistema apropriado para a construção de edificações em série, devido à facilidade de produção de peças com mesma seção e comprimentos, o que não se aplica a projetos individualizados, que geraria uma gama de peças com seções e comprimentos diferentes, o que poderia causar transtornos e confusões durante o processo de montagem.

- Sistema de pré-fabricação parcial, subdivido em: a) sistema de pré-fabricação de painéis geralmente construídos com critérios de coordenação modular, com dimensões uniformes e utilização de um módulo como unidade de medida. São pré-fabricados tanto painéis de parede como também painéis de piso, forro e cobertura. Tais painéis podem ser pré-fabricados utilizando-se vários níveis de mecanização, desde a utilização de ferramentas simples, 
quanto de equipamentos com maior grau de tecnologia, diminuindo portanto, o trabalho e a utilização de equipamentos no canteiro de obra e, b) sistema de pré-fabricação de componentes, que consiste na fabricação de componentes que incluem instalações e acabamentos primários. Podem ser transportados com janelas e vidros instalados, evitando problemas de montagem apresentados pelo sistema de painéis. Devido ao peso e dimensões dos componentes é necessária a utilização de equipamentos como gruas e equipes de içamento para seu posicionamento na obra. Tal sistema pode não ser muito apropriado em lugares onde a disponibilidade de mão-de-obra e fatores climáticos não sejam determinantes para redução de custos de montagem.

- Sistema de pré-fabricação total ou volumétrica: sistema de montagem tridimensional onde as edificações são montadas na fábrica, necessitando na obra somente a realização de poucas etapas, sendo a principal, a execução de fundações, conferindo um trabalho muito maior na fábrica do que na obra. A área de construção das edificações varia de 10 a $50 \mathrm{~m}^{2}$, principalmente devido ao grande volume a ser transportado, conferindo-lhe uma grande dificuldade e elevação no custo de transporte.

A Figura 14 apresenta os sistemas construtivos citados, identificando os níveis de trabalho na obra e em unidades de pré-fabricação. 

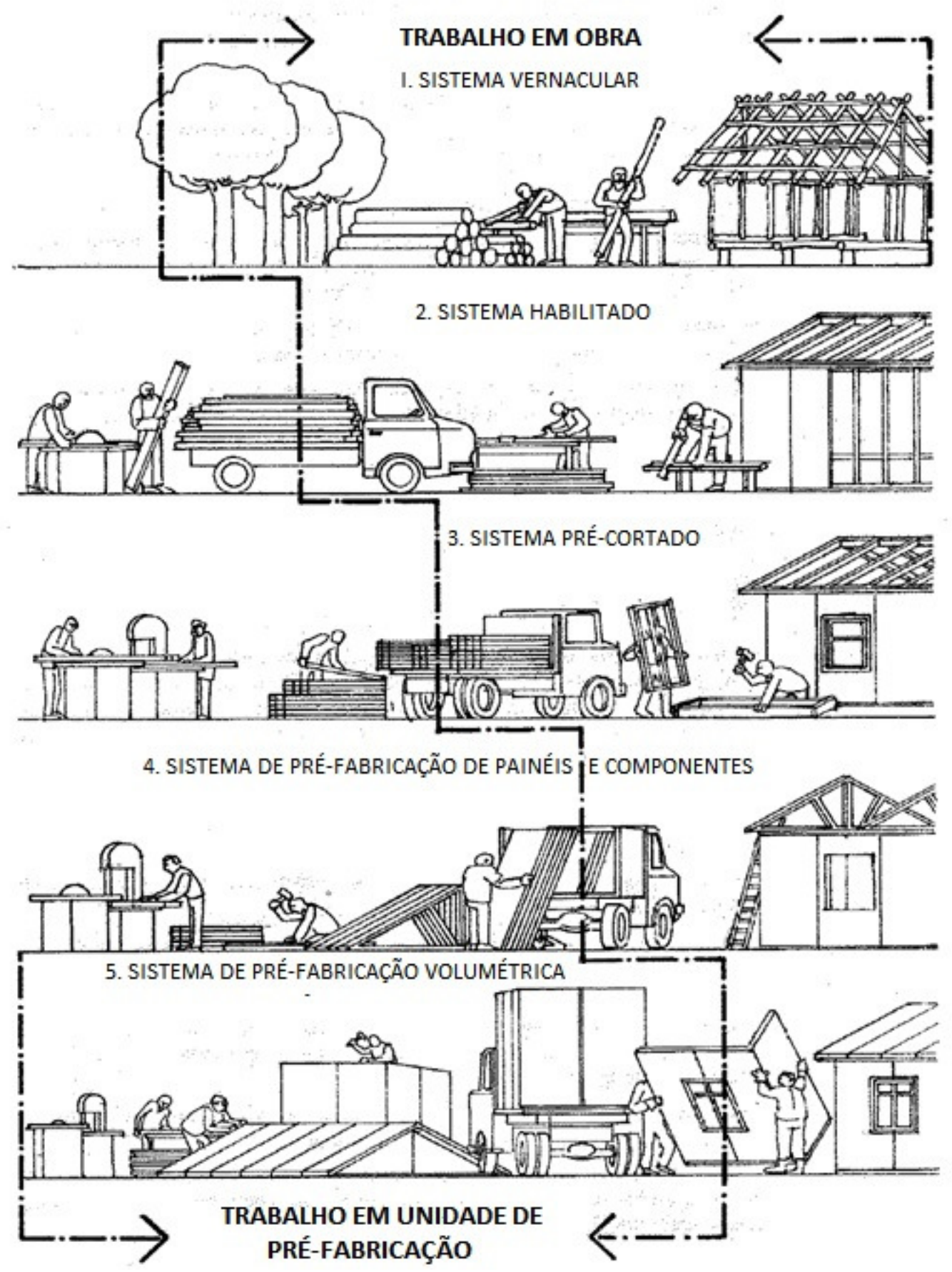

Figura 14 - Tipos de sistemas construtivos com madeira Fonte: Adaptado de JUNAC (1984)

Os sistemas industrializados têm como principais vantagens: a otimização econômica e ecológica das edificações; a redução no desperdício de materiais e melhor gestão de resíduos; a redução de mão-de-obra qualificada devido ao aumento da produção mecanizada; a redução no prazo de execução de obra e ociosidade de mão de obra, minimização de erros construtivos e poluição nos canteiros; o aumento da qualidade dos componentes e consequentemente da 
edificação; a redução dos custos de produção devida à padronização de peças e componentes produzidos em série.

Segundo Bittencourt (1995a), tal processo produtivo pode ser classificado como sistema construtivo racionalizado visto que as atividades em canteiro de obra são exclusivamente de encaixe e montagem dos componentes.

Em um levantamento dos sistemas construtivos que empregam a madeira de florestas plantadas, Cunha e César (2003) verificaram que muitos deles utilizam a madeira de Pinus serrada (sistema pilar-viga, sistema de paredes autoportantes compostas de pranchas horizontais e o sistema Plataforma ("Platform Framing")) e outros o Eucalyptus na sua forma roliça (sistema estrutural de pilar-viga e as edificações de troncos ou toras empilhadas denominadas de "log homes"). Segundo os autores, raras vezes se encontrou o emprego do eucalipto serrado.

\subsubsection{Edificações com componentes estruturais pré-fabricados de madeira}

Nesta etapa serão apresentadas quatro edificações (Projeto IMAFLORA I; Projeto IMAFLORA II; Edificação Unifamiliar na cidade de Sousas - SP e; Salão de Eventos - Ecolog Florestal Ltda.) onde foram utilizados sistemas construtivos préfabricados tipo pilar-viga que empregam a madeira em seus componentes estruturais.

O que cabe ressaltar é que, como são raras as edificações onde são empregadas o Eucalyptus serrado, as edificações apresentadas a seguir são construídas com madeira nativa provenientes de áreas de manejo florestal certificado, sendo que o importante é a análise dos detalhes construtivos entre pilarfundação e pilar-viga, que poderiam ser, na maioria das vezes substituídos por madeira proveniente de florestas plantadas, salvo em situações onde a seção transversal das peças maciças utilizadas dificultaria sua obtenção. Uma possibilidade seria a utilização de peças compostas para a formação de seções maiores, apresentadas posteriormente nos detalhes das interfaces propostas no presente trabalho.

Outro aspecto importante a ser destacado é que em todos os projetos apresentados é clara a percepção do uso da coordenação modular com a utilização 
de módulos estruturais, o que proporcionou uma maior padronização na execução dos componentes em unidades de pré-fabricação, minimizando assim, os ajustes realizados no canteiro de obras e consequentemente o desperdício de material.

Serão apresentadas as diretrizes que balizaram o desenvolvimento dos projetos arquitetônicos e dos sistemas construtivos estruturais de cada edificação, em seguida o projeto das interfaces entre os componentes estruturais. O intuito é apresentar diferentes possibilidades de interfaces entre os componentes estruturais pilar-fundação e pilar-viga utilizados em obras executadas.

\subsubsection{IMAFLORA I}

Ficha Técnica

Nome: Sede do Instituto de Manejo Florestal e Agrícola (IMAFLORA)

Local: Piracicaba - SP

Projeto: 2001

Conclusão da obra: 2002

Área do terreno: $1.103,60 \mathrm{~m}^{2}$

Área construída: $330,00 \mathrm{~m}^{2}$

Arquitetura: Grupo de Pesquisa em Habitação e Sustentabilidade (HABIS) da Escola de Engenharia de São Carlos (USP) e Grupo de Estudos sobre a Qualidade das Edificações (GEsQE) da Universidade Federal de São Carlos

Concepção do projeto arquitetônico

O projeto foi idealizado para abrigar a sede do Instituto de Manejo Florestal e Agrícola (IMAFLORA), dotado de 1 pavimento com pé-direito duplo e 1 mezanino, a edificação possui salas de escritório, reuniões, áreas administrativas e sanitários, perfazendo uma área total de $330,00 \mathrm{~m}^{2}$. A edificação é elevada do solo, o que permitiu que não houvesse necessidade de movimentação de terra, preservando portanto, o perfil original do terreno.

A Figura 15 apresenta as etapas de montagem da estrutura, vedação e acabamento da obra. 


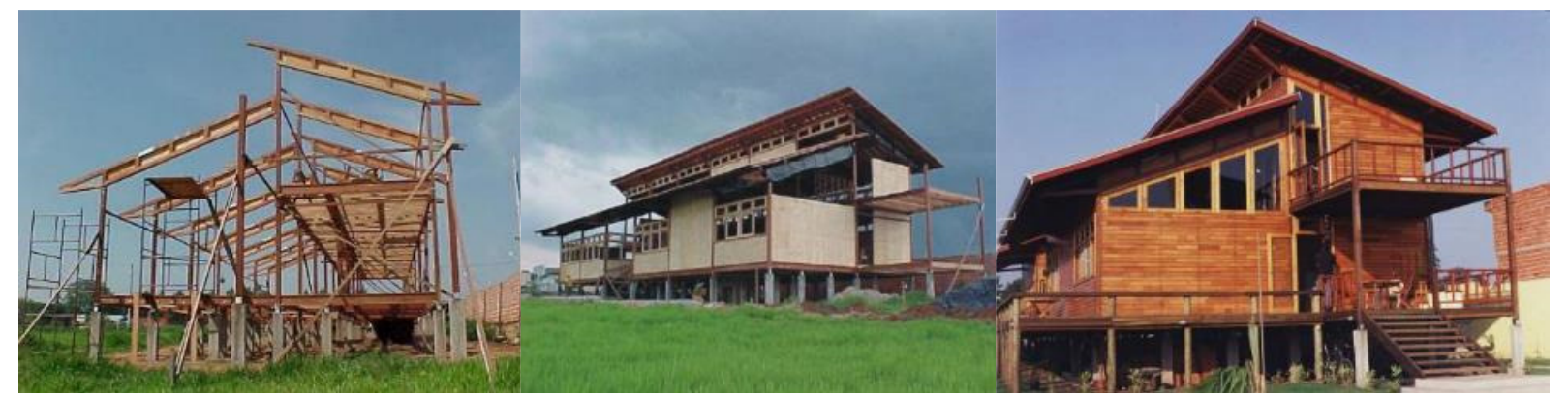

Figura 15 - IMAFLORA I - Montagem da estrutura, vedação e acabamento Fonte: Autor

Concepção estrutural do projeto

O sistema construtivo adota uma concepção estrutural pilar-viga, a partir de módulos estruturais principais de $4 \times 4 \mathrm{~m}$ e $4 \times 5 \mathrm{~m}$ entre eixos, o que permitiu a utilização de um módulo de painel de vedação de $1 \mathrm{~m}$. Foram utilizados pilares maciços com seção de $12 \times 12 \mathrm{~cm}$ e vigas compostas, tipo perfil I, com alturas de $22 \mathrm{e}$ $26 \mathrm{~cm}$.

A Figura 16 apresenta a planta do barroteamento de piso com as cotas dos eixos modulares do projeto. 


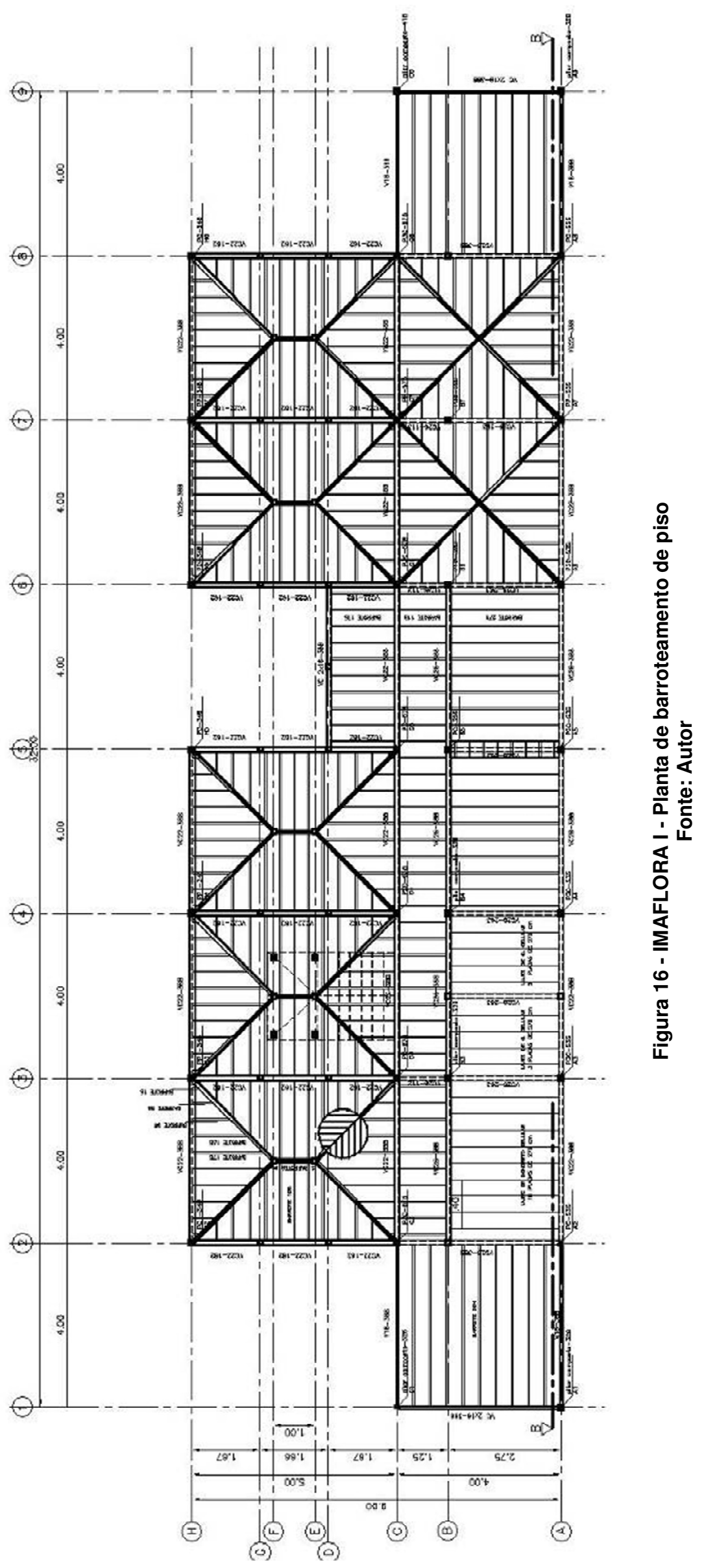


Interfaces entre componentes estruturais pré-fabricados

Os componentes estruturais apresentados são os pilares maciços com seção de $12 \times 12 \mathrm{~cm}$ e as vigas compostas, tipo perfil I, com alturas de 22 e $36 \mathrm{~cm}$ definidas em cálculo estrutural.

A interface pilar-fundação foi executada utilizando-se um conector metálico aparafusado em uma barra roscada deixada como espera após a concretagem dos pilaretes de concreto. Sua fixação ao pilar se deu através da passagem de duas barras roscadas, com o posterior travamento através de porcas e arruelas.

As interfaces entre pilares e vigas compostas foram executadas da mesma forma, com a utilização de conectores metálicos, projetados individualmente dependendo da quantidade de vigas que chegavam aos pilares.

A Figura 17 apresenta a interface entre pilar-fundação e duas variações de conectores metálicos responsáveis pela interface pilar-viga.

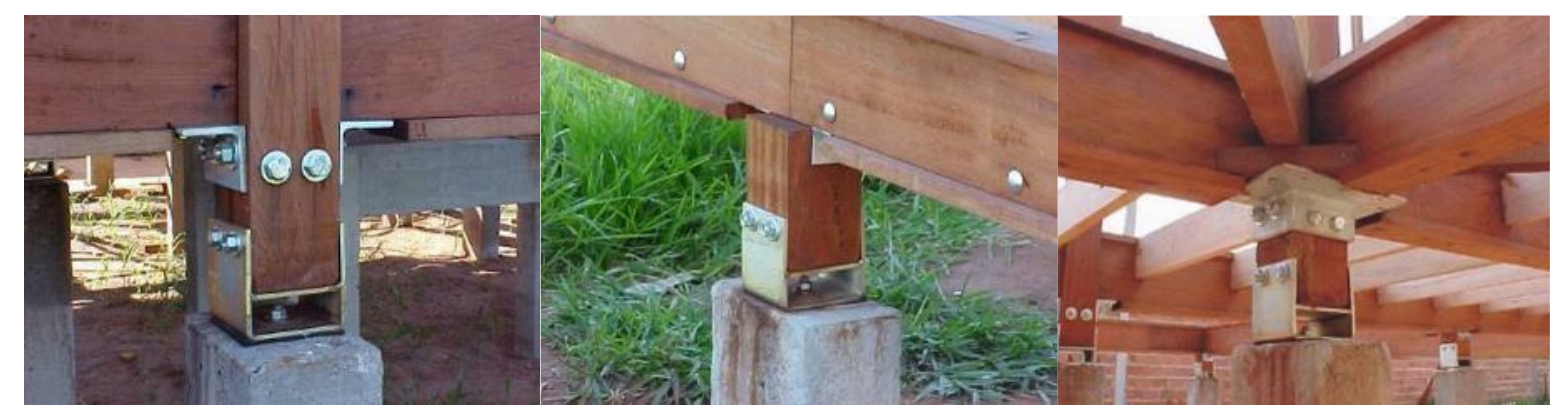

Figura 17 - IMAFLORA I - Interfaces pilar-fundação e pilar-viga composta Fonte: Autor

\subsubsection{IMAFLORA II}

Ficha Técnica

Nome: Ampliação da sede do Instituto de Manejo Florestal e Agrícola (IMAFLORA)

Local: Piracicaba - SP

Projeto: 2006

Conclusão da obra: 2007

Área do terreno: $1.231,05 \mathrm{~m}^{2}$ 
Área construída: $191,25 \mathrm{~m}^{2}$

Arquitetura: Arquiteta Lúcia Zanin Shimbo

Concepção do projeto arquitetônico

O projeto, dotado de 1 (um) pavimento, possui uma área total de 191,25 m². A partir da concepção modular adotada no partido arquitetônico foi elaborado o projeto executivo estrutural.

Em relação aos demais materiais de construção empregados na edificação, destacam-se os tijolos de solo-cimento intertravados como elementos de vedação vertical, que também contribuem para o contraventamento do conjunto de pilares, as esquadrias e pisos de madeira nativa certificada e o piso cerâmico nas áreas úmidas, assentado sobre laje suspensa por barrotes de madeira.

A utilização do tijolo de solo-cimento contribuiu para a redução da extração de argila e poluição devido à queima do material e possibilitou a passagem das instalações elétricas no interior dos furos dos tijolos, bem como entre as vigas duplas da estrutura de piso.

A Figura 18 apresenta as etapas de estrutura, vedação e acabamento da obra.

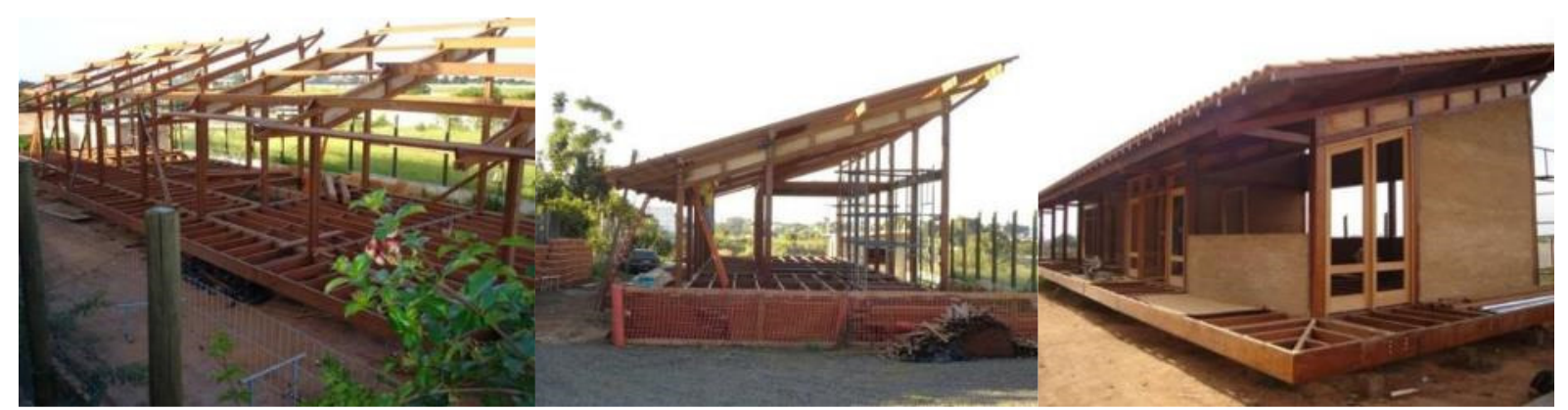

Figura 18 - IMAFLORA II - Montagem da estrutura, vedação e acabamento Fonte: Autor

Concepção estrutural do projeto

O sistema construtivo adota uma concepção estrutural pilar-viga, a partir de módulos estruturais de $2 \times 4 \mathrm{~m}$ e $4 \times 4 \mathrm{~m}$ entre eixos, formados por componentes simples (vigas duplas e barrotes) e componentes compostos (pilares e treliça de cobertura) de madeira serrada maciça e chapas de compensado. 
Foram adotados pilares compostos montados a partir de duas peças brutas de $6 \times 16 \mathrm{~cm}$ e uma peça interna de $6 \times 12 \mathrm{~cm}$, formando uma seção final de $15,5 \times 15,5 \mathrm{~cm}$, conforme apresentado na Figura 19. A adoção deste sistema visa tanto uma redução no custo do componente quanto promover um menor impacto ambiental na retirada de peças de grande seção, uma vez que as peças nas seções indicadas são facilmente encontradas no mercado. Este componente apresenta ainda, nas faces laterais rebaixos com $4,5 \mathrm{~cm}$ de largura e $0,5 \mathrm{~cm}$ de profundidade para encaixe da peça de interface pilar/vedação. Esta solução visou resolver o aparecimento de eventuais frestas entre o componente pilar e o elemento de vedação.

As vigas duplas são compostas por 2 peças com seções de $5,5 \times 23 \mathrm{~cm}$ e $5,5 \times 28 \mathrm{~cm}$.

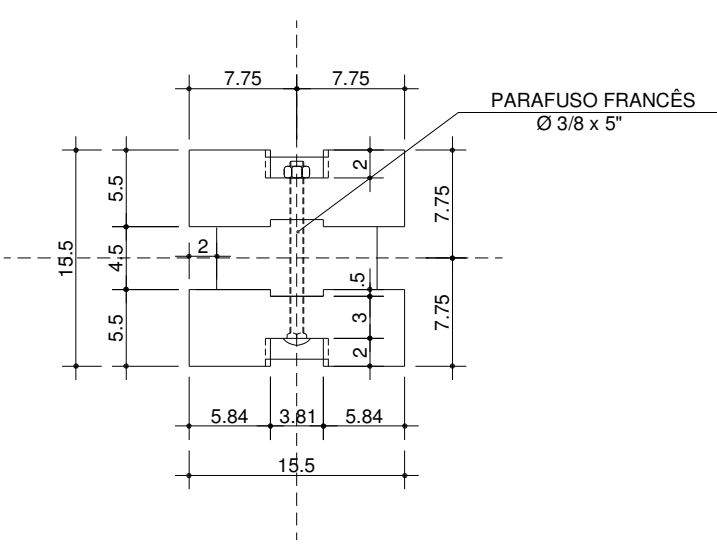

SEÇÃO HORIZONTAL ESCALA $1 / 5$

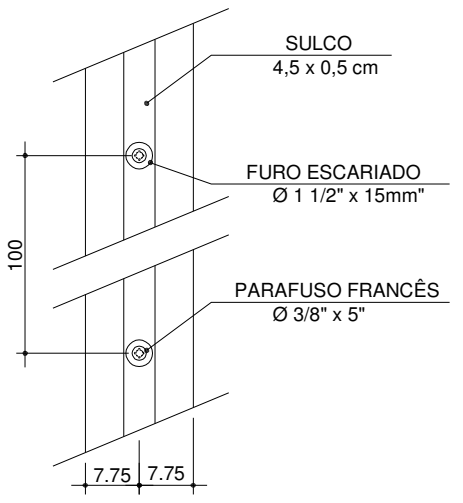

ELEVAÇÃO ESCALA $1 / 10$

Figura 19 - IMAFLORA II - Detalhe pilar composto Fonte: Autor

A Figura 20 apresenta a planta do barroteamento de piso com as cotas dos eixos modulares, indicação de componentes e indicação de detalhes construtivos, compatibilizados na fase de projeto. 


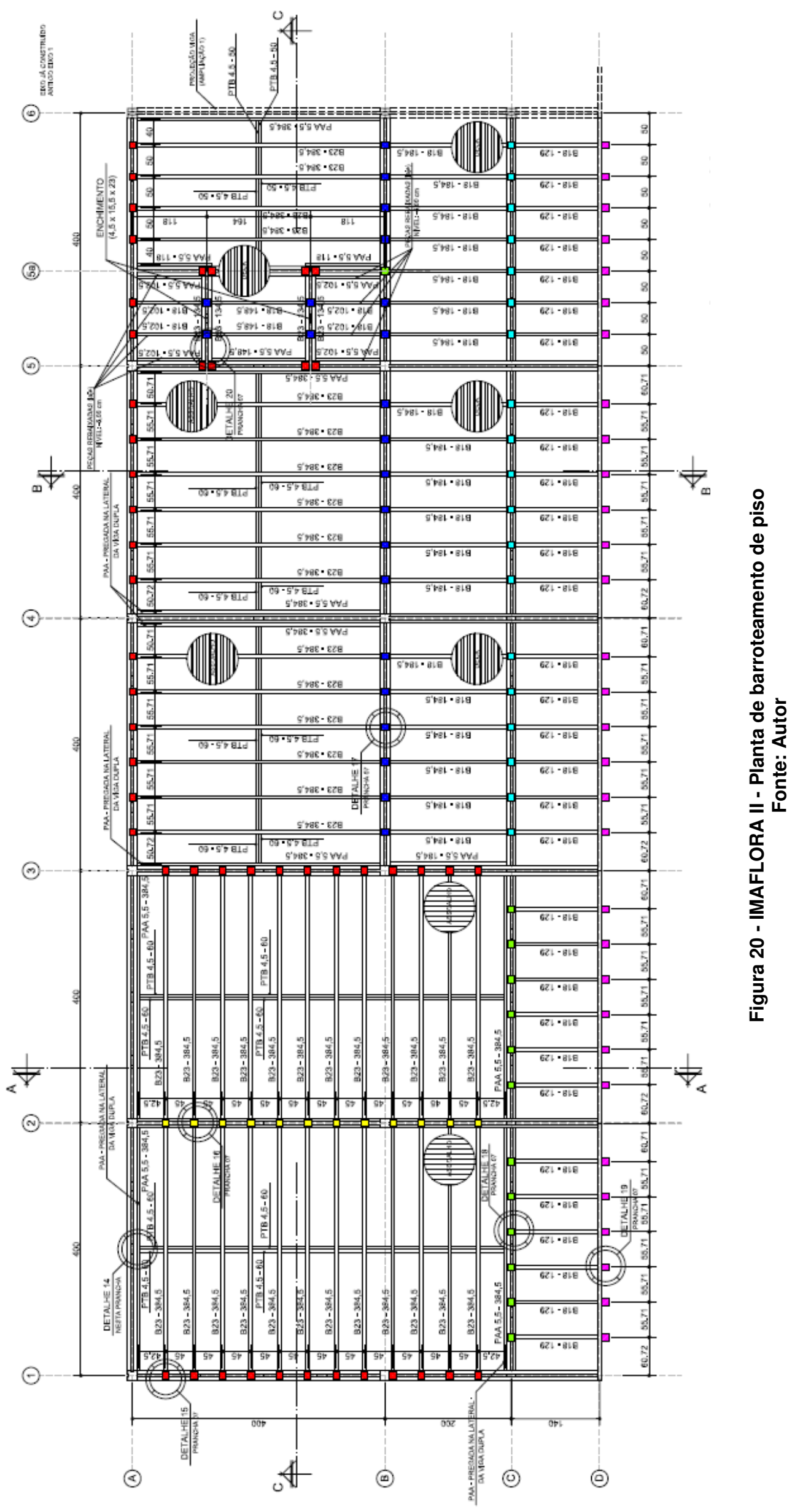


A Figura 21 apresenta o corte AA com a especificação dos componentes estruturais, tais como, pilares compostos, vigas duplas, barrotes (nível 0,00m), estrutura de piso, vigamento superior (nível 2,87m) e a estrutura de cobertura com a indicação da treliça composta, terças, caibros e ripas. Também são identificadas as interfaces entre os pilares de madeira e os pilaretes de concreto armado fixados às sapatas isoladas da fundação, adotadas para melhor aproveitamento do terreno natural, além do fato de tais sapatas utilizarem menos material para sua execução, quando comparadas às sapatas corridas e radiers de concreto armado, por exemplo.

Outros fatores que merecem destaque são: o fato da edificação estar elevada em relação ao terreno natural, que não sofreu agressão, pois não foi necessária uma movimentação de terra para a implantação da edificação, além não impermeabilizar o solo; e a adoção de um deck frontal, que cria uma área aberta sombreada, aumentando o conforto térmico no interior da edificação, minimizando o consumo de energia artificial para climatização durante sua fase de utilização.

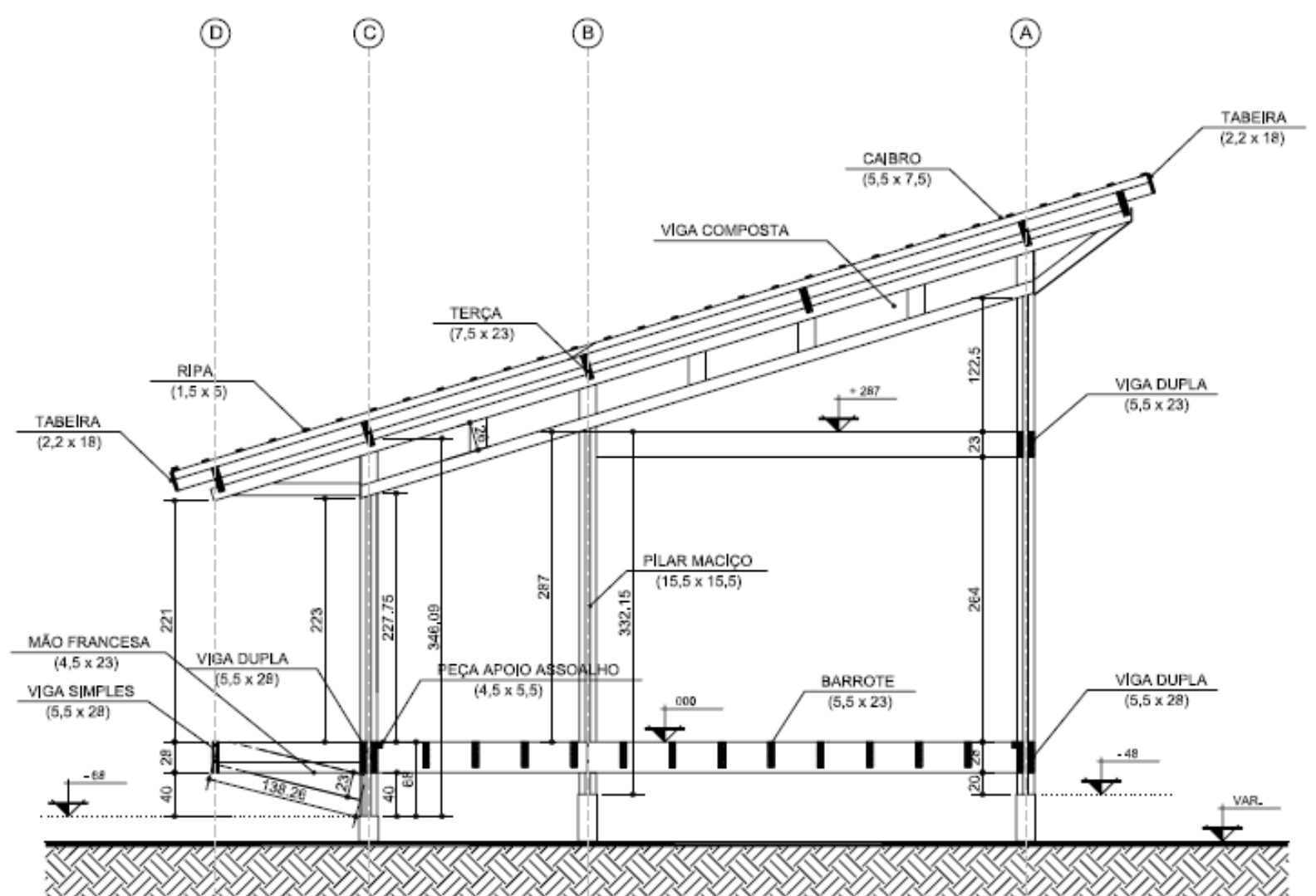

Figura 21 - IMAFLORA II - Corte AA

Fonte: Autor 
Interfaces entre componentes estruturais pré-fabricados

- Interface pilar-fundação

A fundação da edificação foi executada com a concretagem de sapatas e pilaretes de concreto com seção $15 \times 15 \mathrm{~cm}$ dotados de um orifício central de diâmetro de $75 \mathrm{~mm}$ e profundidade de $30 \mathrm{~cm}$ para possibilitar a inserção de um conector metálico inserido na base do pilar composto, como pode ser verificado no projeto da interface apresentado na Figura 22.

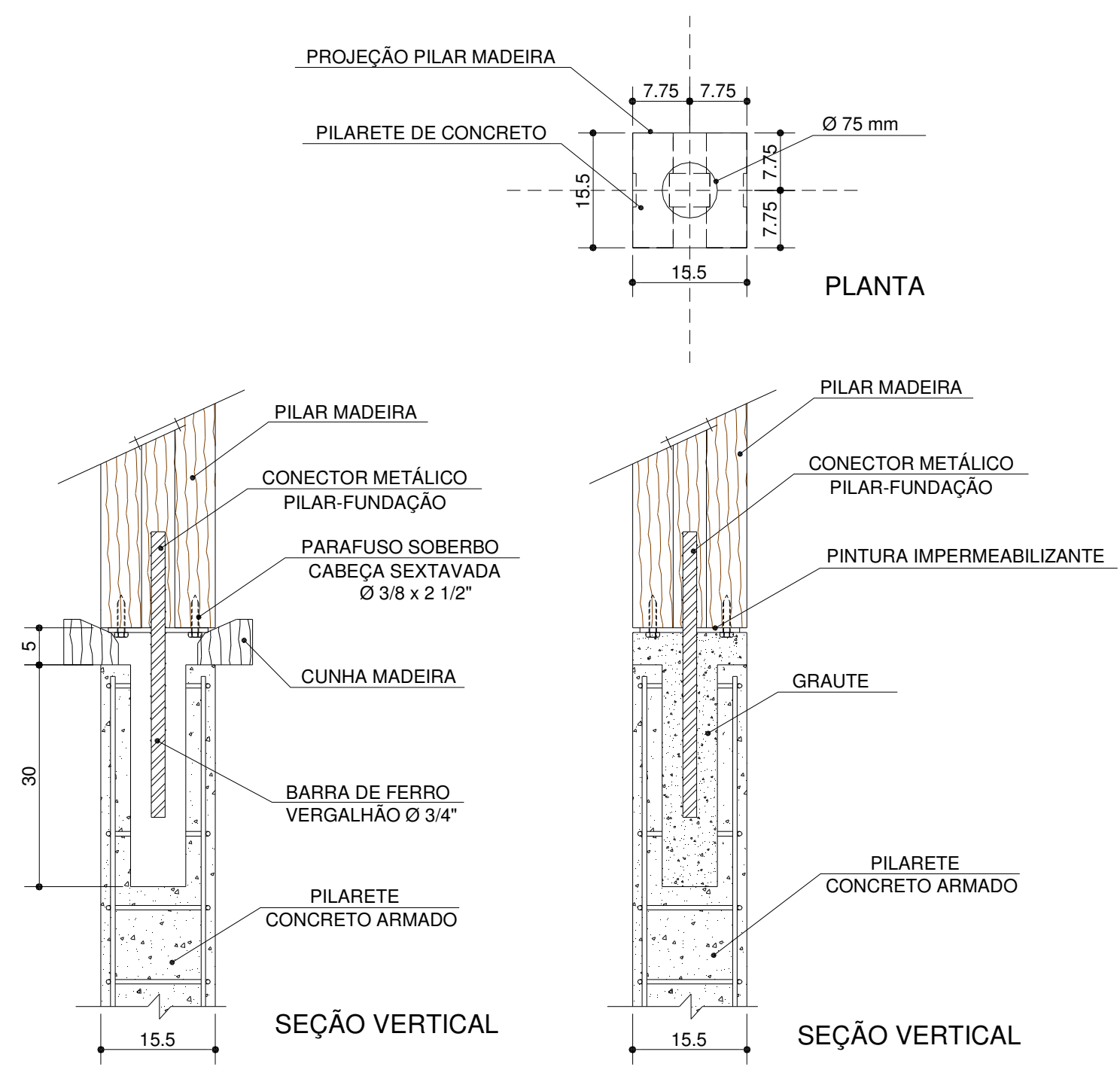

Figura 22 - IMAFLORA II - Interface pilar composto-fundação Fonte: Autor 
- Interface pilar-viga

A interface entre os componentes pilar/viga-dupla foi executada com auxílio de conectores metálicos galvanizados a fogo, sendo empregados parafusos passantes e parafusos tipo soberbo, dependendo da situação de cada ligação. A Figura 23 apresenta o projeto da interface entre o pilar composto e três vigas duplas.
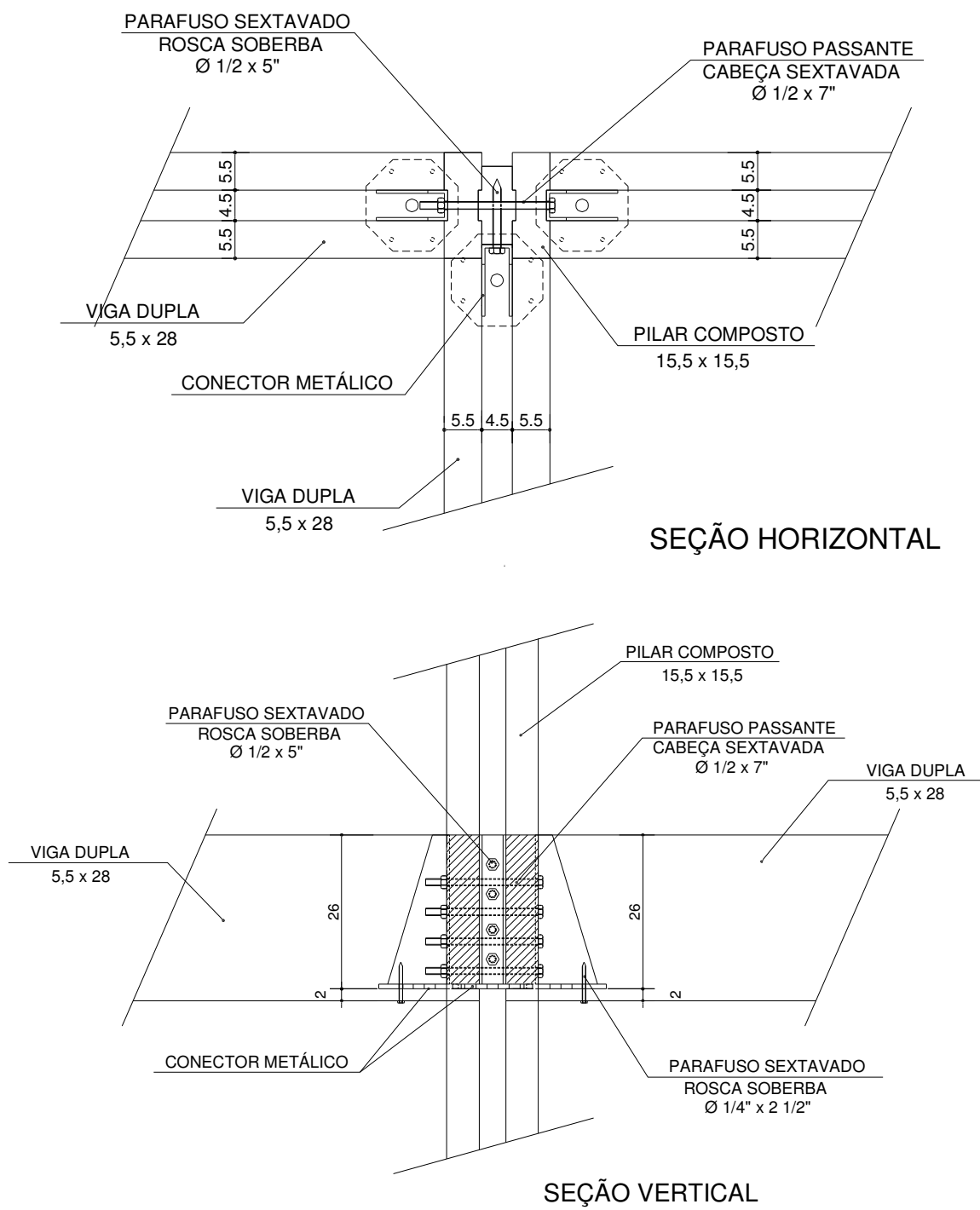

Figura 23 - IMAFLORA II - Detalhe interface pilar composto - 3 vigas duplas Fonte: Autor

A Figura 24 apresenta as interfaces pilar-fundação e pilar-viga executadas em obra, onde nota-se na interface pilar-fundação um espaço existente entre o topo do 
pilarete de concreto e base do conector metálico onde o pilar está apoiado, posteriormente preenchido com graute. Já na interface pilar-viga nota-se uma usinagem da face lateral do pilar, necessária para o encaixe do conector metálico, gerando como resíduo uma pequena quantidade de serragem na unidade de préfabricação. Nota-se também a interface entre pilar-3 vigas duplas devidamente montada.

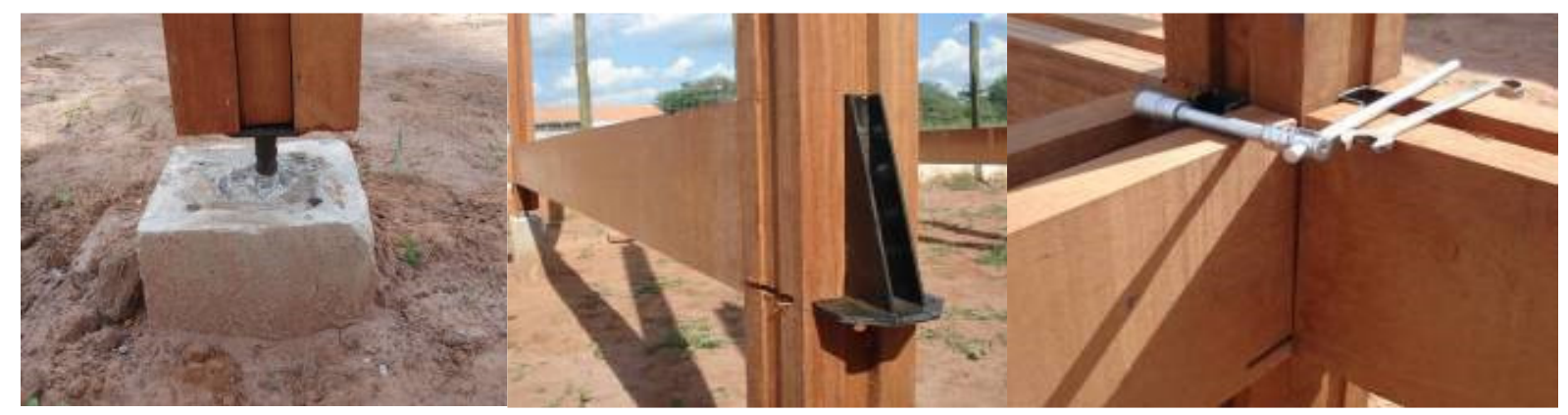

Figura 24 - IMAFLORA II - Interfaces pilar-fundação e pilar-viga executadas em obra Fonte: Autor

\subsubsection{RESIDÊNCIA UNIFAMILIAR - SOUSAS-SP}

Ficha Técnica

Nome: Residência Álvaro Augusto Vasconcelos

Local: Sousas - SP

Projeto: 2008

Conclusão da obra: não construída

Área do terreno: $9.70,22 \mathrm{~m}^{2}$

Área construída: $445,00 \mathrm{~m}^{2}$

Arquitetura: Arquitetos Daniel Matoso Argoud e Tomaz Queiroz Ferreira Barata

\section{Concepção do projeto arquitetônico}

A edificação possui uma área de $445,00 \mathrm{~m}^{2}$ distribuídos em 3 níveis. O partido arquitetônico adotado desde os primeiros estudos preliminares priorizou um resultado formal que refletisse a concepção da estrutura. $O$ arranjo estrutural do projeto partiu de uma forma cúbica com um pilar central, para garantir maior 
estabilidade e permitir a liberação do envoltório para o posicionamento das aberturas e varandas. Desde a fase de estudo preliminar a forma cúbica possuía uma base de 10×10m formando, em planta, quatro módulos de $5 \times 5 \mathrm{~m}$. Em um destes módulos foi projetado um vão interno e nos outros três módulos foi distribuído o programa de necessidades. Ao longo da evolução do projeto esta base foi ganhando novos elementos, como por exemplo, a escada destacada da estrutura principal. A Figura 25 apresenta o modelo tridimensional da edificação.

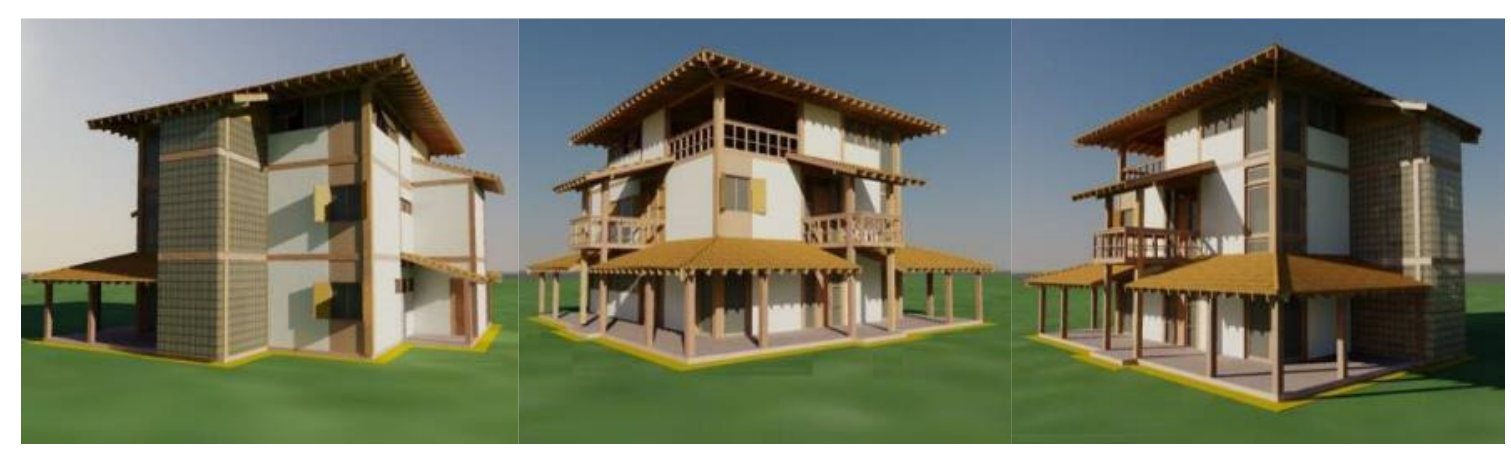

Figura 25 - Edificação Sousas - Maquete eletrônica tridimensional da edificação Fonte: Autor

Concepção estrutural do projeto

Foi adotada uma concepção estrutural pilar-viga, constituída por componentes simples (pilares, vigas simples, vigas duplas e barrotes) e componentes compostos (treliças de cobertura) de madeira maciça serrada.

Os pilares são maciços com seções $17 \times 17 \mathrm{~cm}, 20 \times 20 \mathrm{~cm}, 22 \times 22 \mathrm{~cm} \mathrm{e}$ $27 \times 27 \mathrm{~cm}$; vigas simples $10 \times 30 \mathrm{~cm}$ e $12 \times 22 \mathrm{~cm}$ e vigas duplas $5,5 \times 15 \mathrm{~cm}$.

$\mathrm{Na}$ Figura 26 são apresentadas as imagens do entramado formado pelos componentes estruturais em madeira maciça e na Figura 27 é apresentado o Corte AA da estrutura da edificação, com a indicação dos componentes estruturais e suas respectivas seções. 


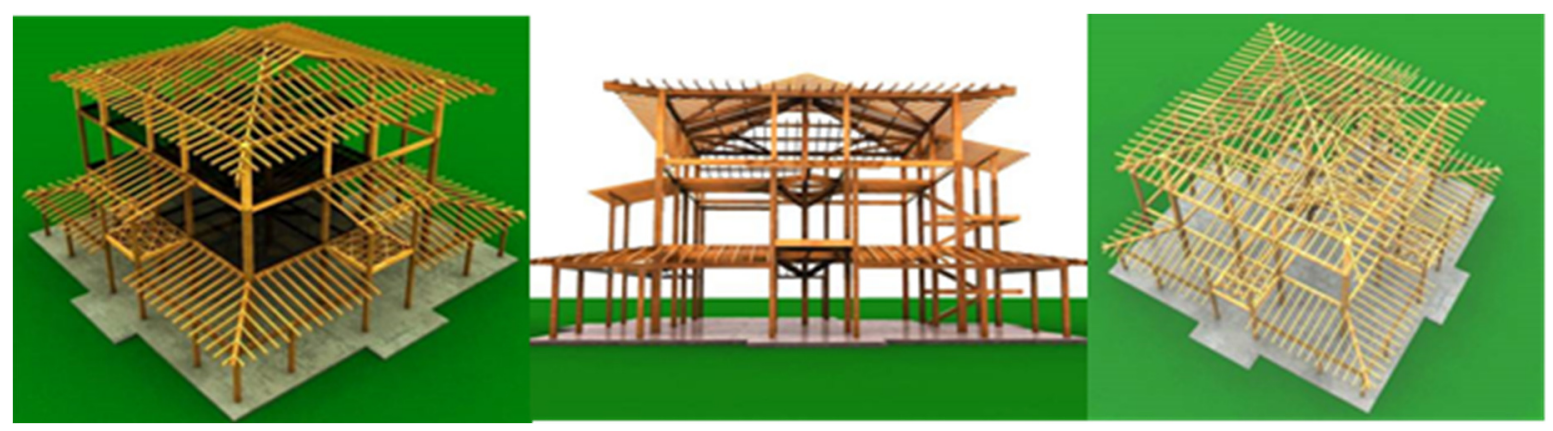

Figura 26 - Edificação Sousas - Maquete eletrônica tridimensional da estrutura da edificação Fonte: Autor

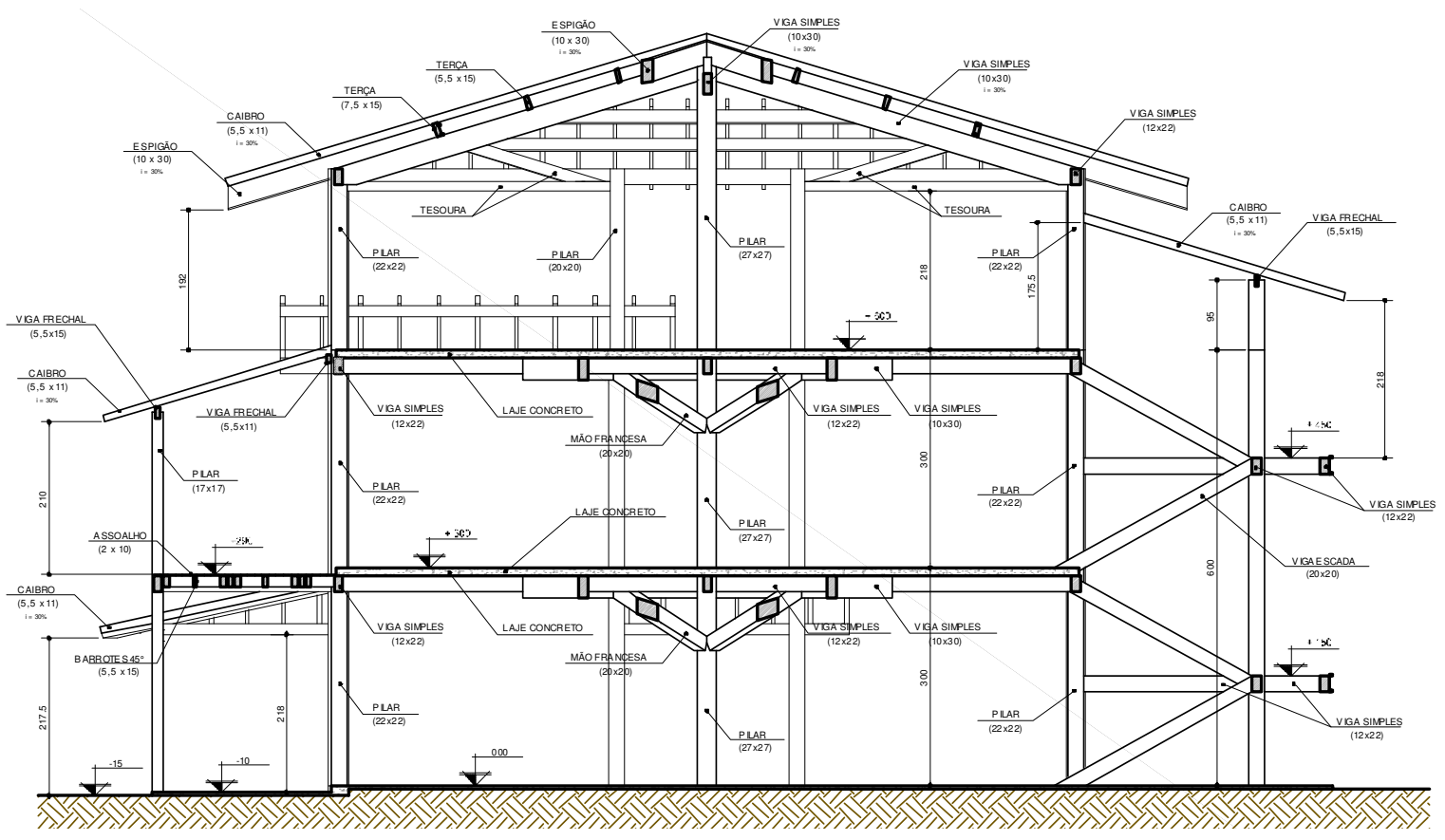

Figura 27 - Edificação Sousas - Corte AA Fonte: Autor

Interfaces entre componentes estruturais pré-fabricados

As ligações entre os componentes pilar-fundação e pilar-viga são executadas com auxílio de conectores metálicos galvanizados a fogo, e uso de parafusos passantes e parafusos tipo soberbo, dependendo da situação de cada ligação. A inserção do conector diminui a necessidade de complexas usinagens e encaixes nas peças de madeira. 
- Interface pilar-fundação

Os pilares foram fixados aos blocos de fundação através de conectores metálicos. A fim de aumentar a estabilidade lateral desta conexão foram utilizadas peças de aço de $10 \mathrm{~mm} \times 2$ ', posicionadas uma em cada face dos pilares, nos devidos rebaixos e inseridas no bloco de fundação. A Figura 28 apresenta o detalhe do pilar maciço e a interface pilar-fundação.
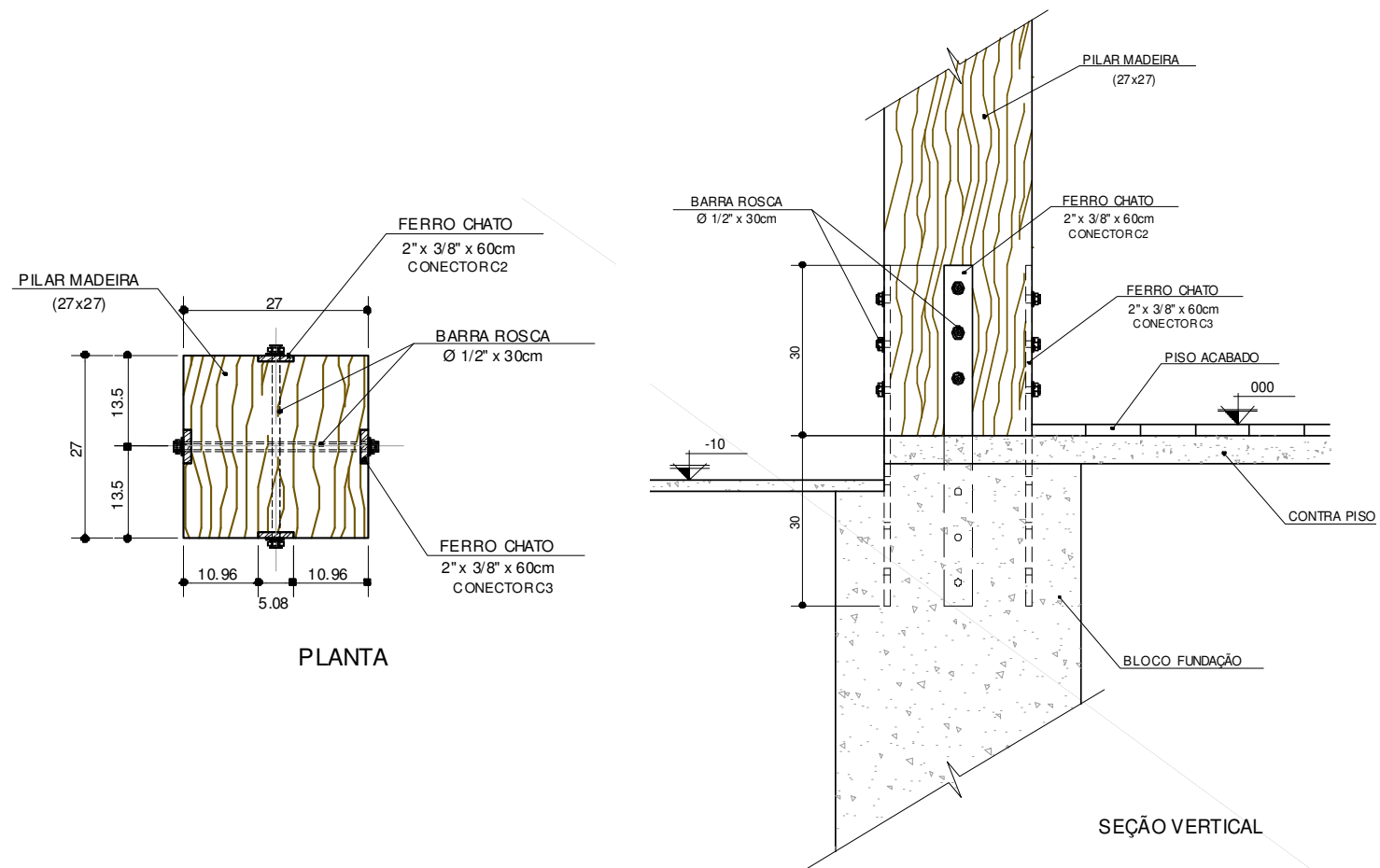

Figura 28 - Edificação Sousas - Projeto da interface pilar-fundação Fonte: Autor

- Interface pilar-viga simples

As vigas simples são peças aparelhadas e pré-cortadas no comprimento definido no projeto de produção e têm seção $10 \times 30 \mathrm{~cm}$ e $12 \times 22 \mathrm{~cm}$. Estas peças possuem uma usinagem na sua face inferior, próxima aos pilares, para encaixe dos conectores metálicos pilar-viga. A Figura 29 mostra o detalhe da interface entre as vigas simples e os pilares. 

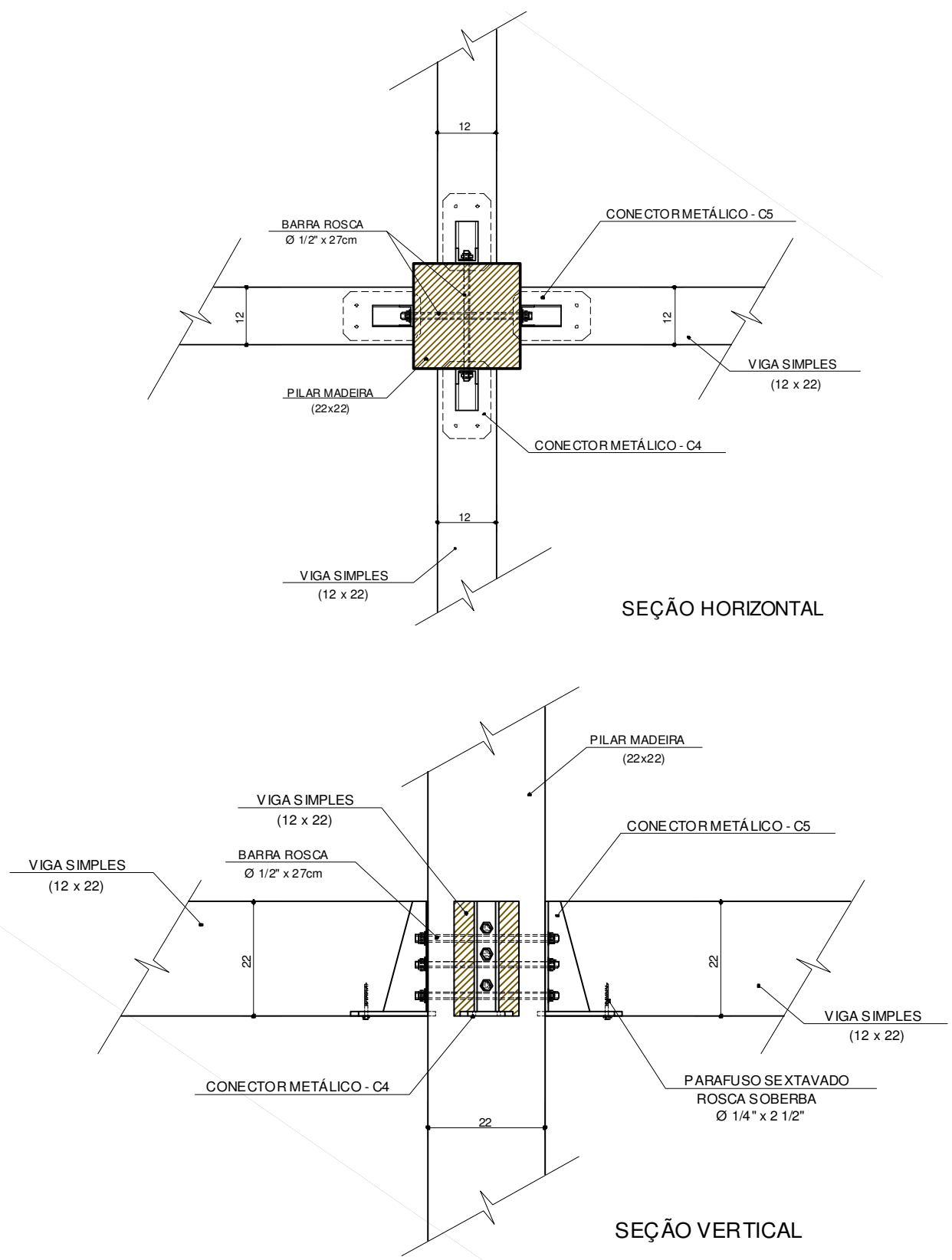

Figura 29 - Edificação Sousas - Projeto da interface pilar-viga simples Fonte: Autor

- Interface pilar-viga dupla

As vigas duplas são peças aparelhadas e pré-cortadas na seção e no comprimento definido no projeto de produção. Estas peças não possuem qualquer tipo de usinagem e/ou rebaixo, o que confere maior agilidade na produção das peças. A fixação nos pilares é feita através de conectores metálicos em forma de "U”, posicionados no interior das mesmas, o que não os deixa aparentes. A Figura 30 apresenta o projeto da interface entre os pilares e as vigas duplas. 


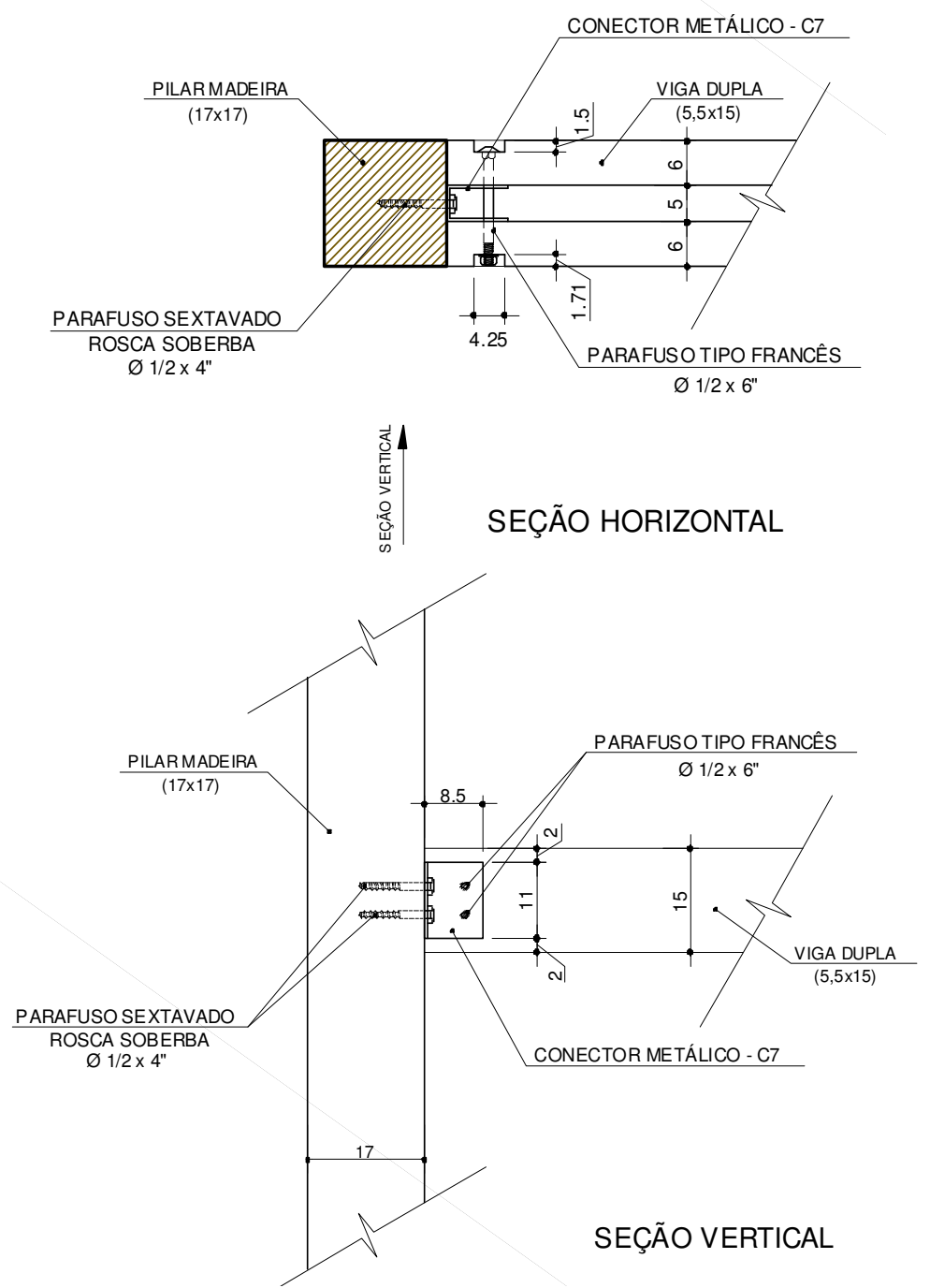

Figura 30 - Edificação Sousas - Projeto da interface pilar-viga dupla Fonte: Autor

\subsubsection{SALÃO DE EVENTOS - ECOLOG FLORESTAL}

Ficha Técnica

Nome: Salão de Eventos Alphavillage- ECOLOG Florestal

Local: Itu - SP

Projeto: 2002

Conclusão da obra: 2004

Área construída: $120,00 \mathrm{~m}^{2}$

Arquitetura: Reinach Mendonça Arquitetos Associados 


\section{Concepção do projeto arquitetônico}

Esta obra está localizada na cidade de Itu - SP, possui 1 (um) pavimento e área construída de $120,0 \mathrm{~m}^{2}$. O sistema construtivo adotado foi: piso elevado em madeira, para preservar o terreno natural, evitando movimentações de terra; laje de concreto apoiada sobre barrotes de madeira nas áreas úmidas; pilares e vigas em madeira serrada aparelhada e alvenaria de tijolos furados. A cobertura é dotada de estrutura de madeira aparente e telhas cerâmicas.

A cobertura possui águas desencontradas, o que permitiu maior ventilação e incidência de iluminação natural no salão principal. A Figura 31 apresenta a obra concluída, onde pode ser observada a elevação da edificação em relação ao terreno natural, as tesouras aparentes do salão principal e o acabamento interno e externo.

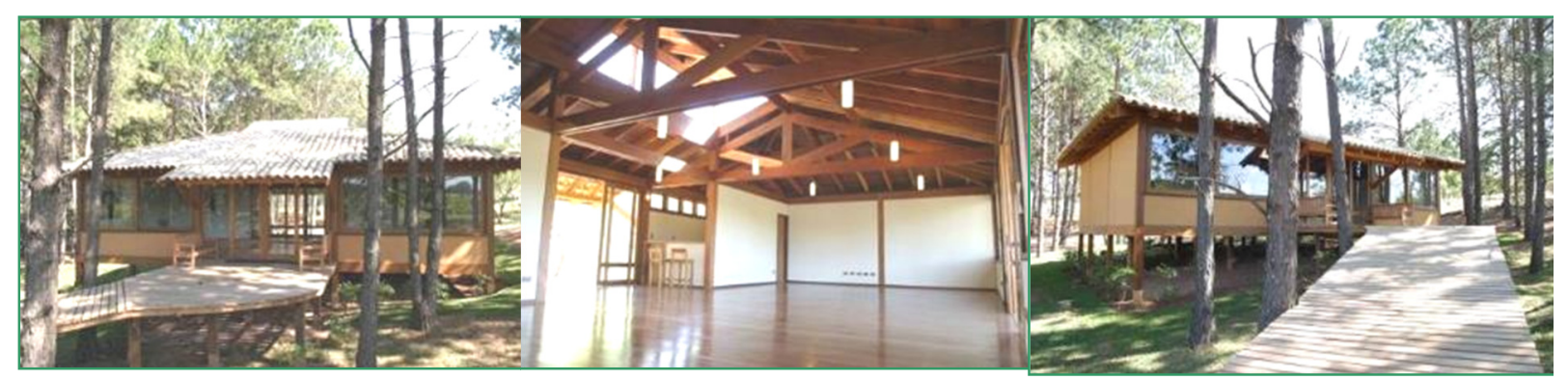

Figura 31 - Salão de Eventos - Obra concluída Fonte: Autor

Concepção estrutural do projeto

O sistema construtivo adotou uma concepção estrutural pilar-viga, formado por componentes simples (pilares, vigas duplas e barrotes) e componentes compostos (tesoura de cobertura) de madeira serrada maciça.

Os pilares são maciços, possuem seção de $17 \times 17 \mathrm{~cm}$ e comprimentos variados devido à topografia natural do terreno, que foi preservada para a implantação da edificação, contribuindo para o afastamento da edificação do solo e mantendo sua permeabilidade.

As vigas duplas são compostas por 2 peças com seções de $5,5 \times 23 \mathrm{~cm}$ e $5,5 \times 28 \mathrm{~cm}$, unidas por um espaçador posicionado no vão de $5 \mathrm{~cm}$ entre as duas peças. 
A Figura 32 apresenta o corte AA da edificação com a indicação dos eixos e os componentes principais.

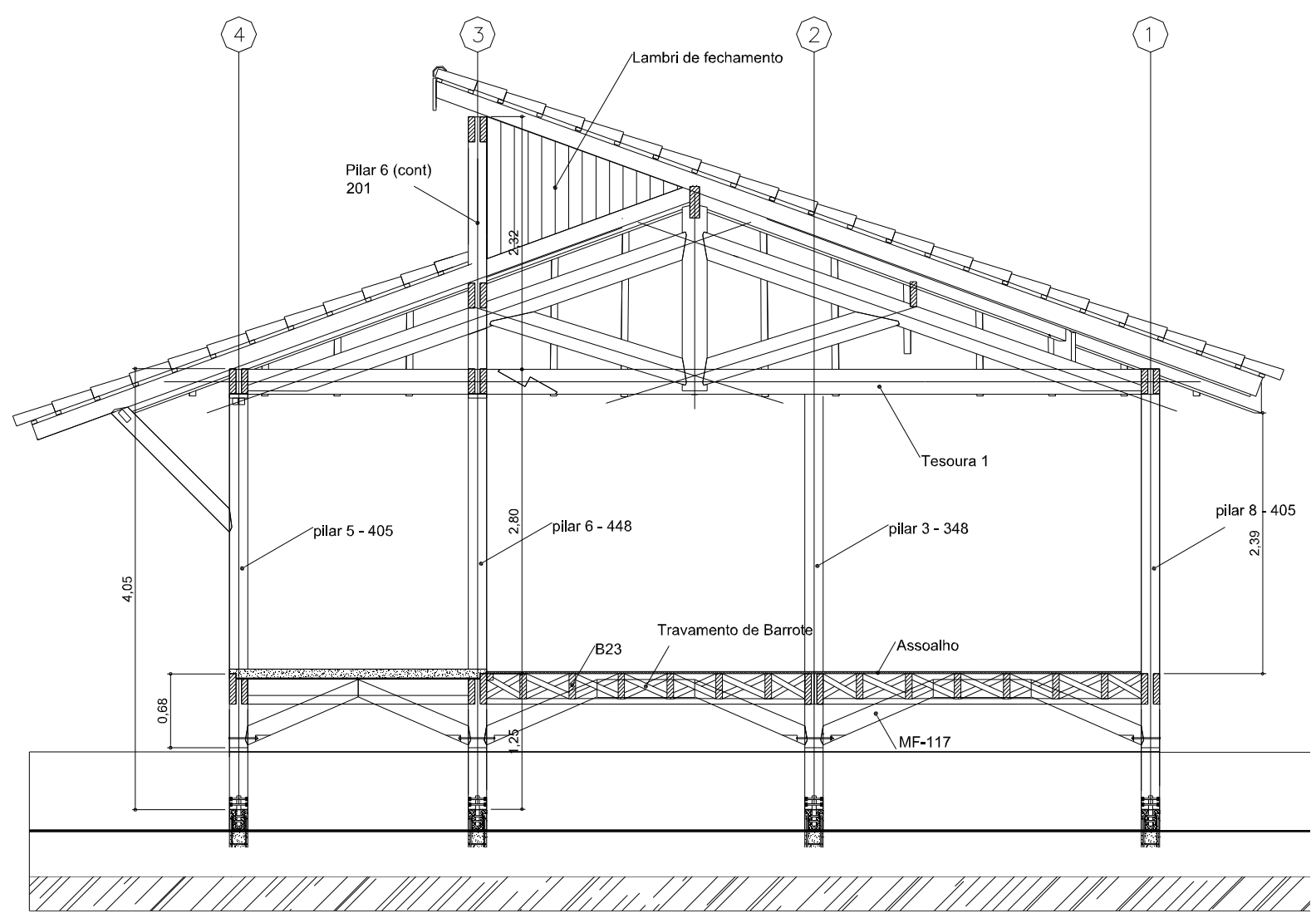

Figura 32 - Salão de Eventos Ecolog - Corte AA Fonte: Autor

Interfaces entre componentes estruturais pré-fabricados

- Interface pilar-fundação

Os pilares de madeira foram apoiados em pilaretes de concreto e afixados aos mesmos através de um tubo metálico de diâmetro $38 \mathrm{~mm}$ com posterior da utilização de graute. $O$ conector foi inserido na base do pilar e fixado com parafusos de $12 \mathrm{~mm}$. O projeto da interface é apresentado na Figura 33. 

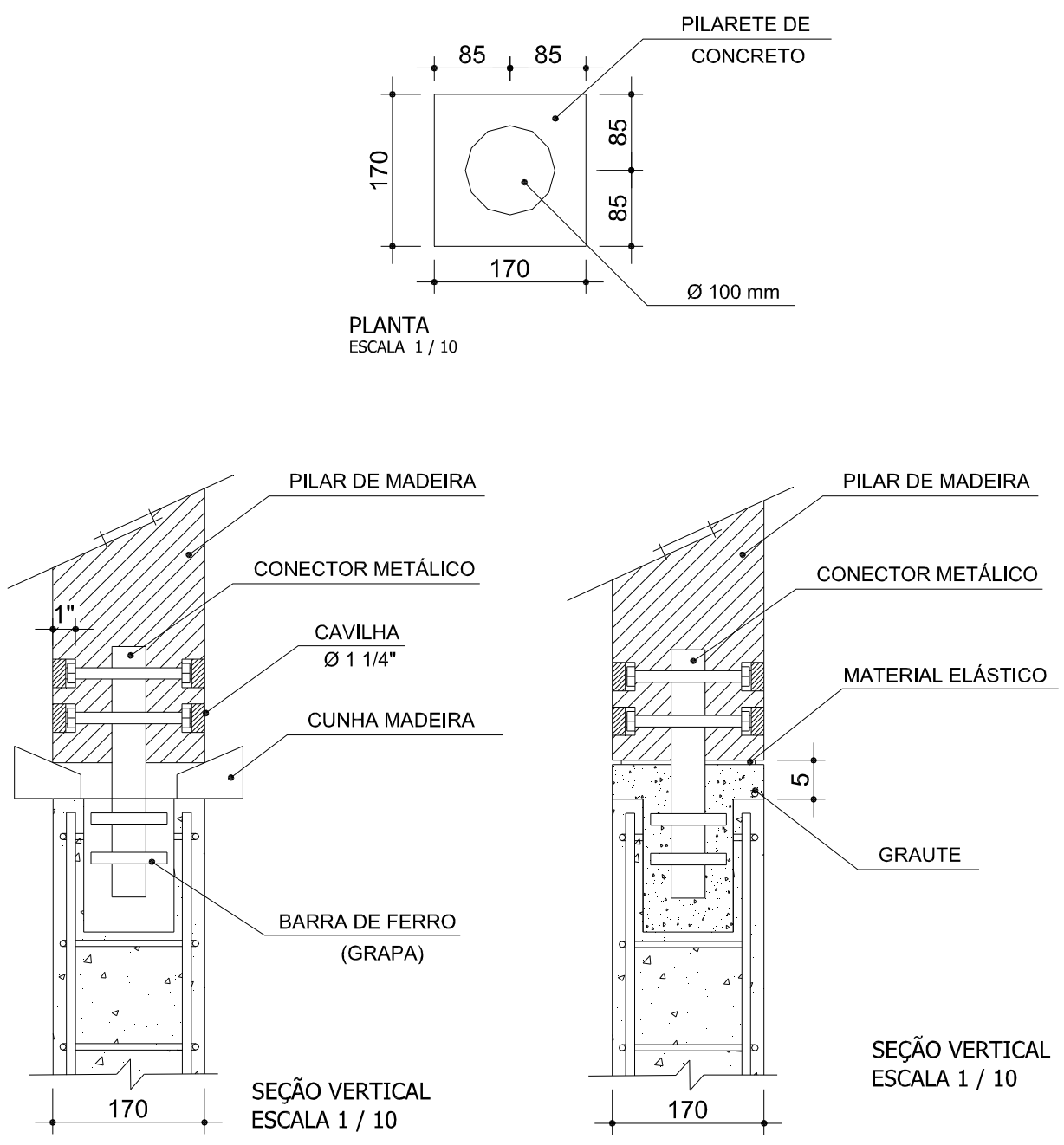

Figura 33 - Salão de Eventos Ecolog - Projeto da interface pilar-fundação Fonte: Autor

- Interface pilar-viga dupla

As vigas duplas desta edificação possuem as mesmas características das vigas da edificação IMAFLORA II. Sua fixação aos pilares se dá através de conectores metálicos com formato parecido à da edificação citada anteriormente, diferindo-se apenas pela alteração do formato hexagonal de sua base para 0 formato retangular, o que conferiu maior precisão, facilidade e agilidade na etapa de produção. A Figura 34 apresenta o projeto da interface entre pilar/viga-dupla e a Figura 35 as interfaces pilar-fundação e pilar-viga executadas em obra. 


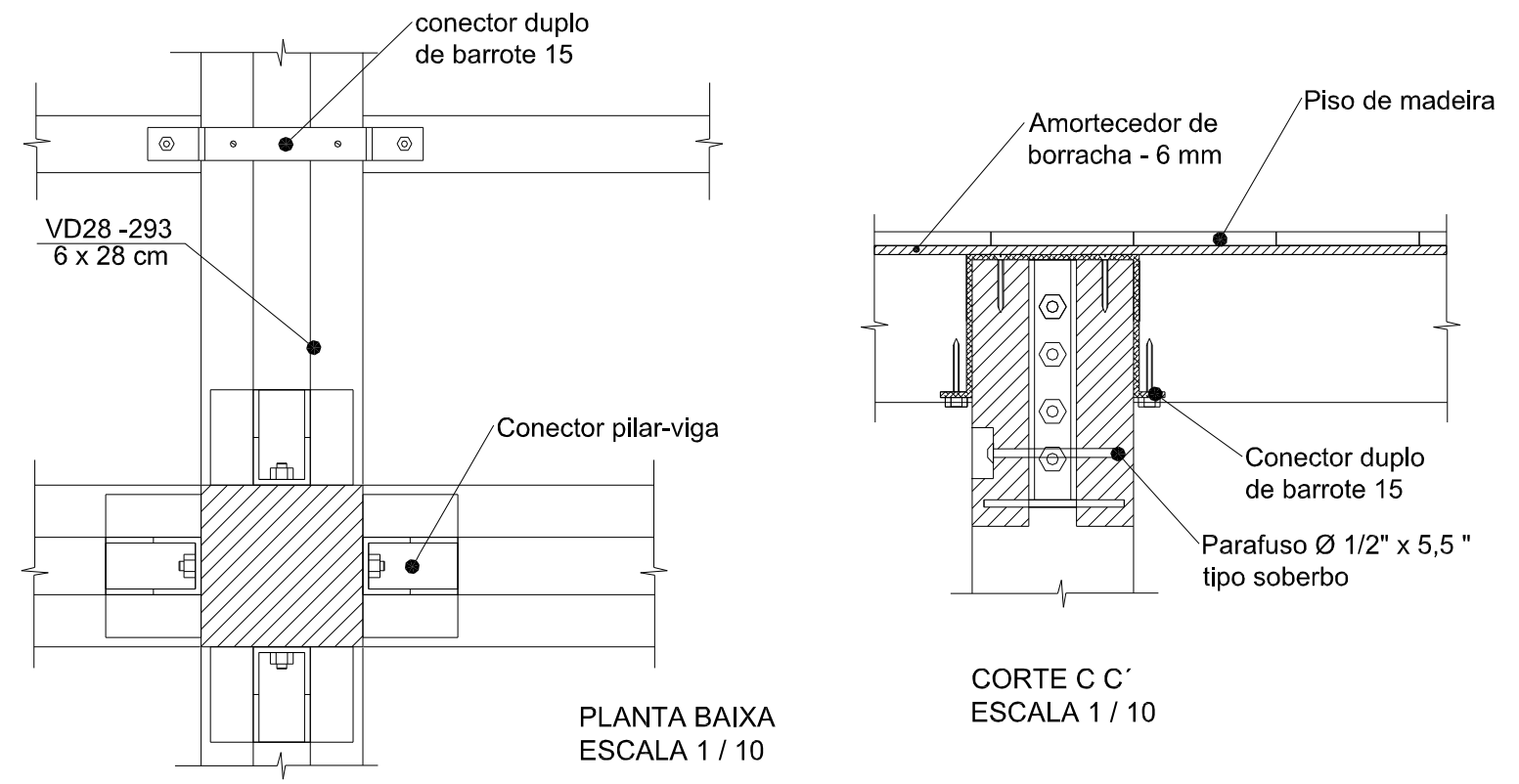

Figura 34 - Salão de Eventos Ecolog - Projeto da interface pilar-viga Fonte: Autor

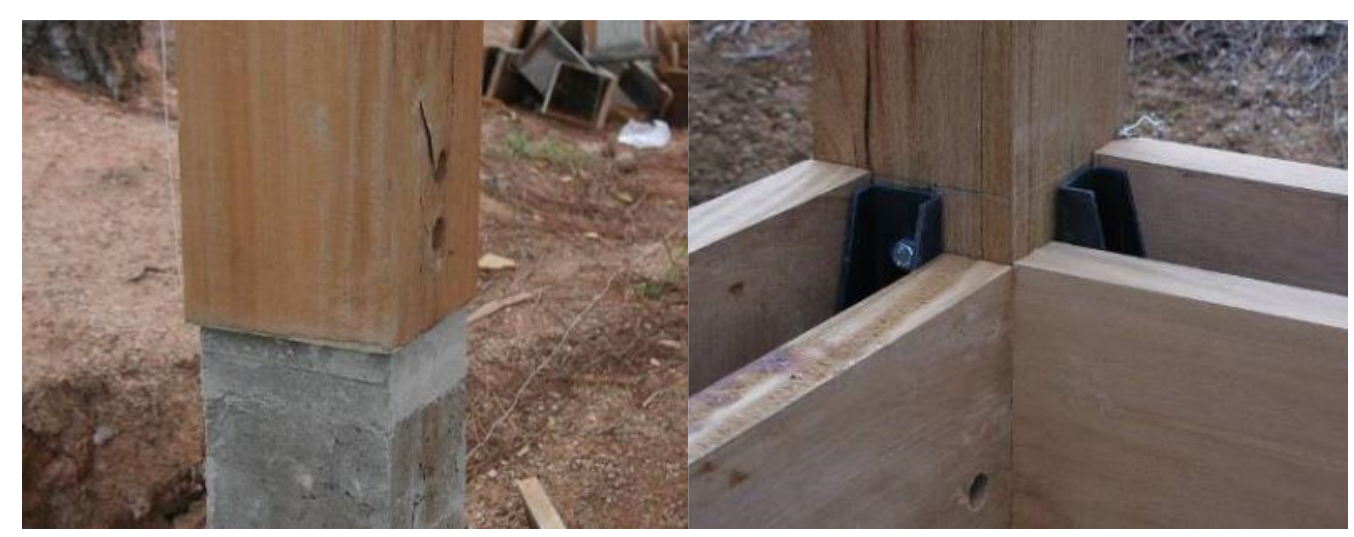

Figura 35 - Salão de Eventos Ecolog - Interfaces pilar-fundação e pilar-viga dupla Fonte: Autor 


\subsubsection{Levantamento e análise de Interfaces}

O levantamento a seguir apresenta várias alternativas de interfaces para o tipo de sistema construtivo pilar-viga.

Foram levados em consideração dois fatores como critério para a escolha das interfaces: a facilidade de execução e montagem. Detalhes mais complexos foram escolhidos e analisados para enriquecer as possibilidades que este sistema construtivo possui e ao mesmo tempo ampliar as alternativas de interfaces.

Os critérios utilizados para a avaliação das interfaces foram:

- Usinagem: dificuldade, tempo e quantidade de equipamentos necessários para execução de detalhes nas peças de madeira;

- Montagem em obra: tempo, dificuldade e quantidade de pessoas necessárias para execução de montagem na obra;

- Ferragens: tipos de conectores metálicos utilizados;

- Absorção de erros: possibilidades de se corrigir possíveis erros na montagem;

- Comentários adicionais: pontos interessantes a respeito da interface.

Do Quadro 3 aoQuadro 5 são apresentadas algumas interfaces que podem ser utilizadas no sistema pilar-viga. 
5.2.2.1 Interfaces pilar-fundação

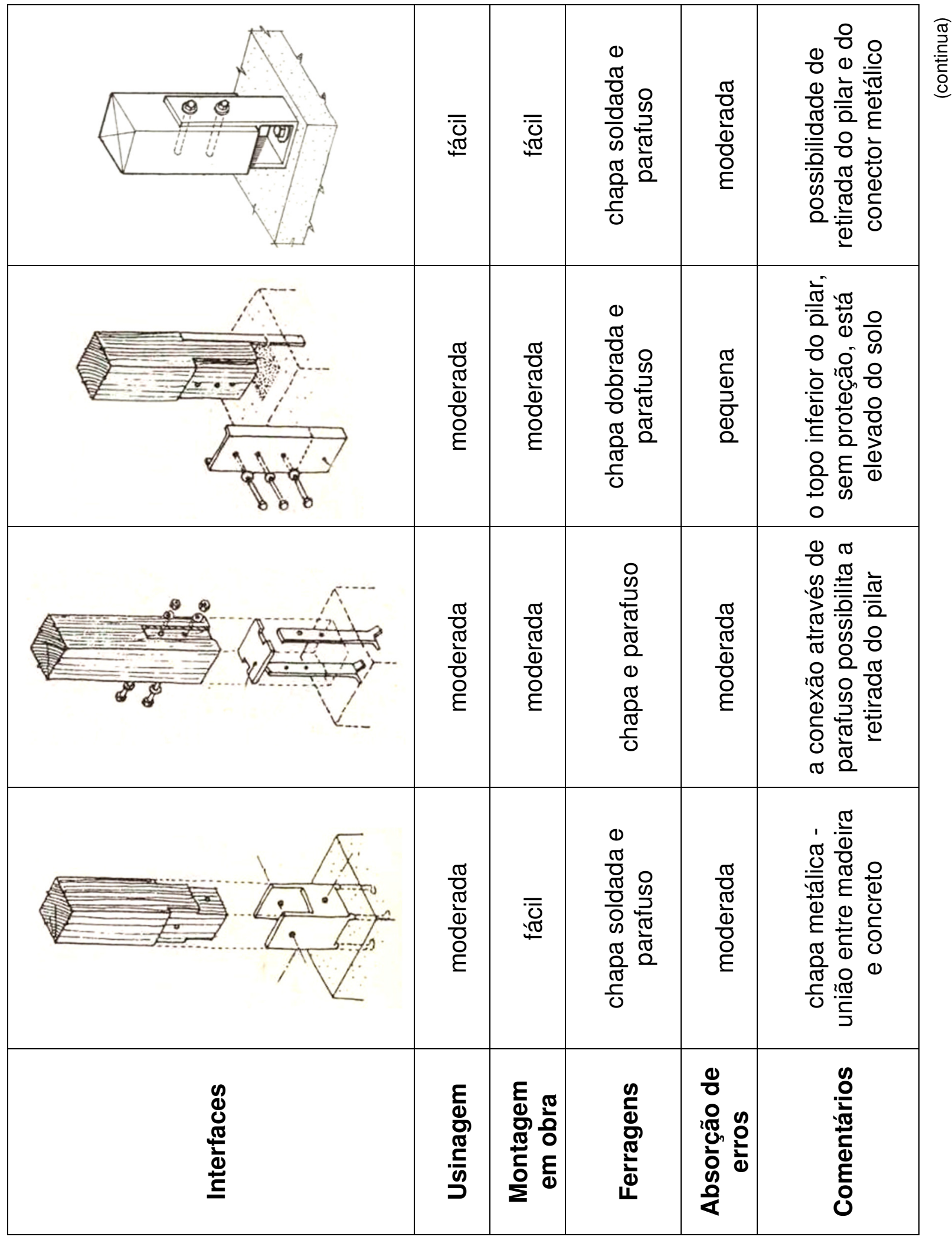




\begin{tabular}{|c|c|c|c|c|c|}
\hline 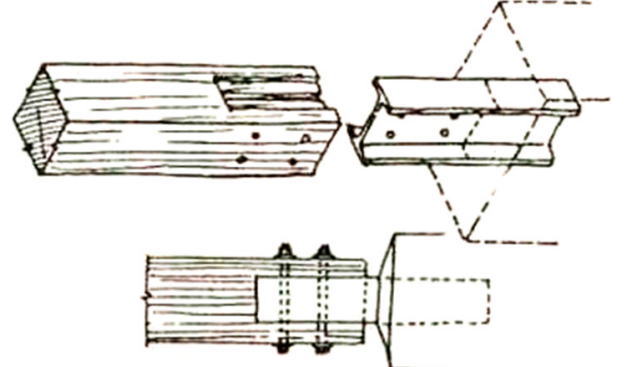 & $\begin{array}{l}\frac{\pi}{0} \\
\frac{\pi}{0} \\
\frac{0}{0} \\
\frac{0}{E}\end{array}$ & $\begin{array}{l}\frac{\pi}{0} \\
\frac{\pi}{0} \\
\frac{0}{0} \\
\frac{O}{E}\end{array}$ & 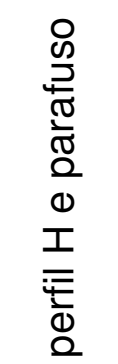 & $\begin{array}{l}\frac{\pi}{0} \\
\frac{\pi}{\frac{\pi}{0}} \\
\frac{0}{0} \\
\frac{1}{\varepsilon}\end{array}$ & 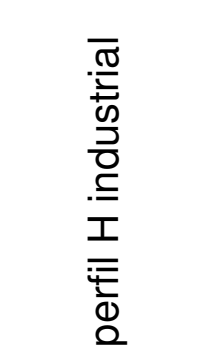 \\
\hline = & $\begin{array}{l}\frac{\pi}{0} \\
\frac{\pi}{0} \\
\frac{0}{0} \\
\frac{0}{E}\end{array}$ & 离 & 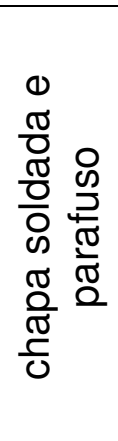 & $\begin{array}{l}\frac{\pi}{0} \\
\frac{\pi}{0} \\
\frac{0}{0} \\
\frac{0}{\varepsilon}\end{array}$ & 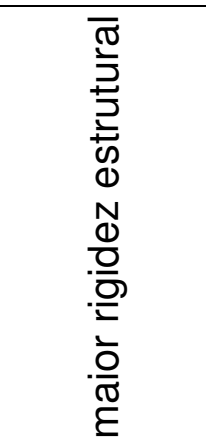 \\
\hline$\stackrel{+\ldots}{=0}$ & $\begin{array}{l}\overline{0} \\
\text { 芯 }\end{array}$ & 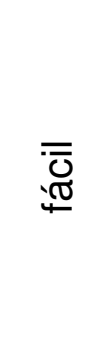 & 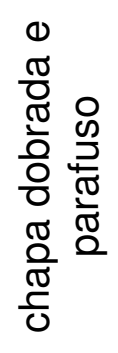 & $\begin{array}{l}\frac{\pi}{0} \\
\frac{\pi}{0} \\
\frac{\pi}{0} \\
\frac{0}{\varepsilon}\end{array}$ & 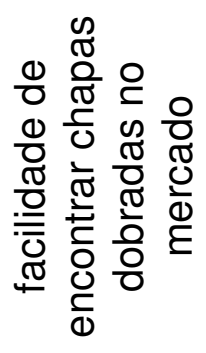 \\
\hline 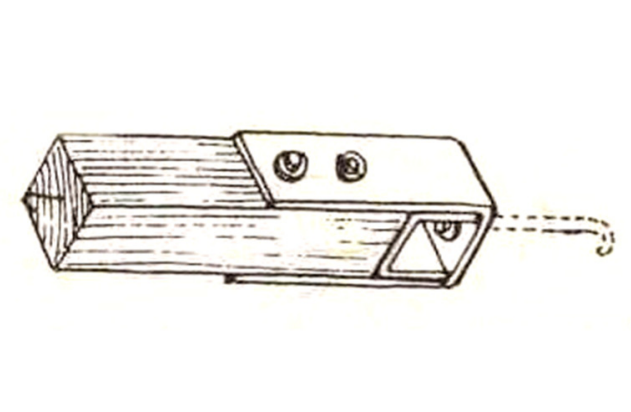 & \begin{tabular}{l}
$\overline{\bar{O}}$ \\
\multirow{2}{*}{}
\end{tabular} & 胥 & 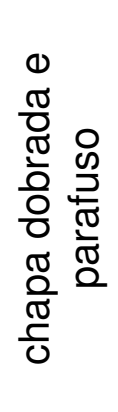 & $\begin{array}{l}\frac{0}{0} \\
\frac{\pi}{\pi} \\
\frac{\pi}{0}\end{array}$ & 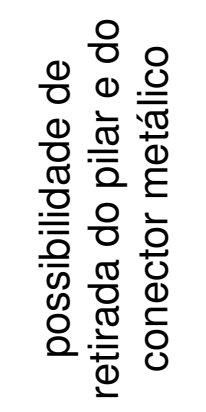 \\
\hline 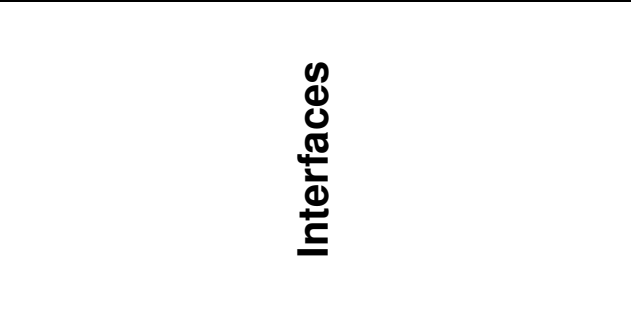 & 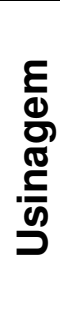 & 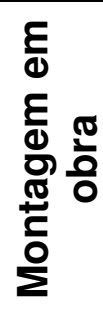 & 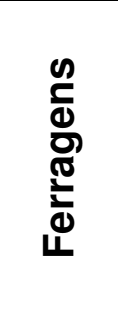 & 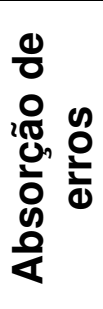 & 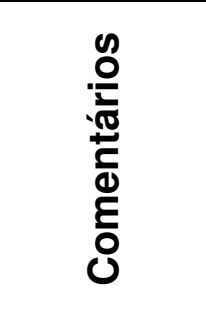 \\
\hline
\end{tabular}




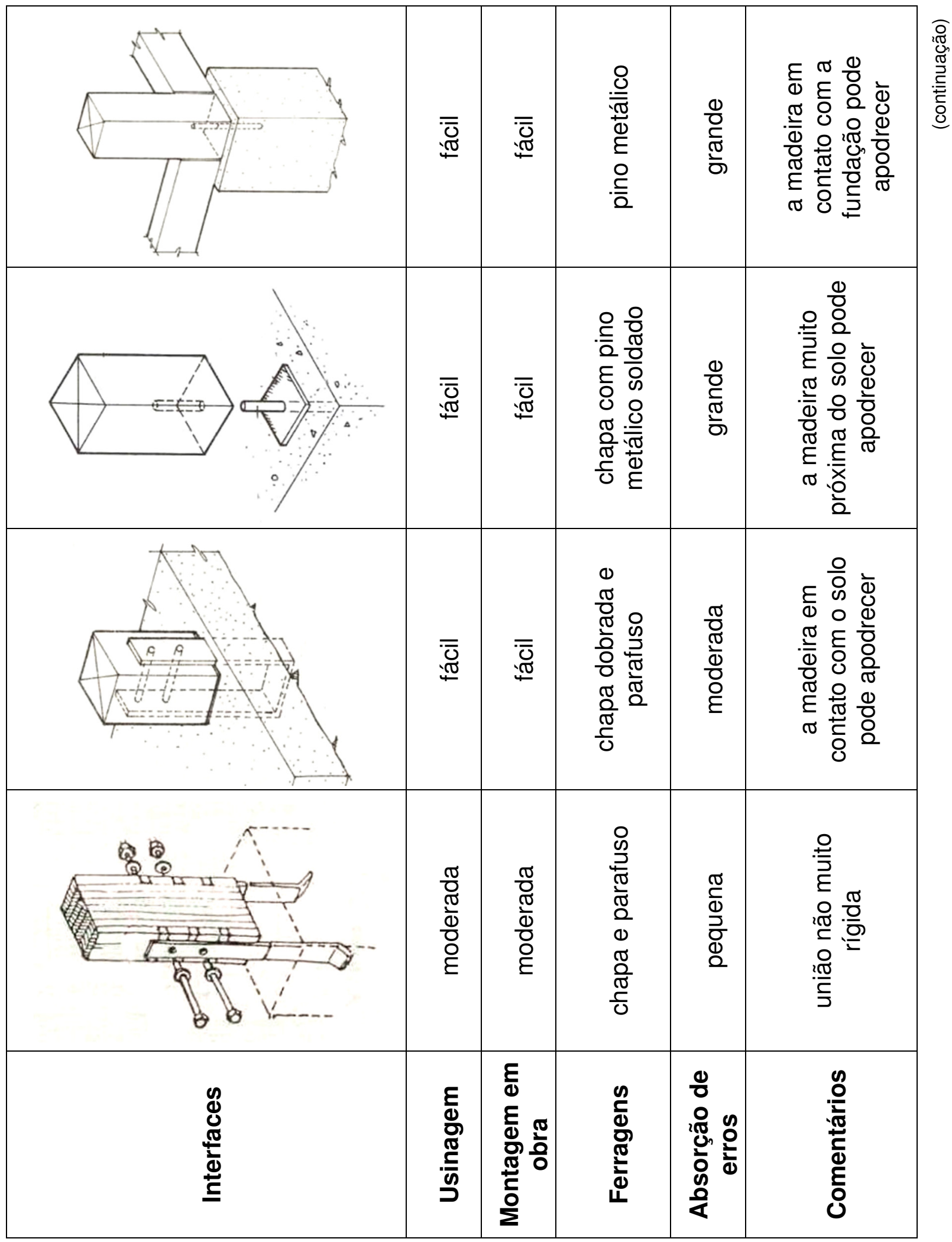




\begin{tabular}{|c|c|c|c|c|c|}
\hline (ivi & 罚 & $\begin{array}{l}\frac{\pi}{0} \\
\frac{\pi}{0} \\
\frac{0}{0} \\
\text { ¿ } \\
\end{array}$ & 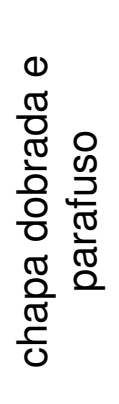 & 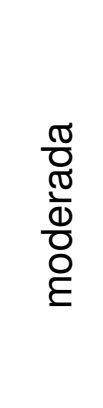 & 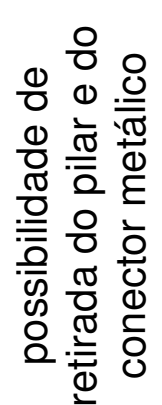 \\
\hline & $\begin{array}{l}\overline{\mathbb{U}} \\
\text { 它 }\end{array}$ & 惡 & 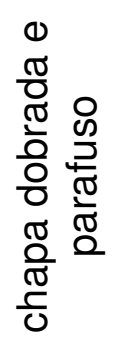 & $\begin{array}{l}\frac{\pi}{0} \\
\frac{\pi}{0} \\
\frac{0}{0} \\
\text { ¿ }\end{array}$ & 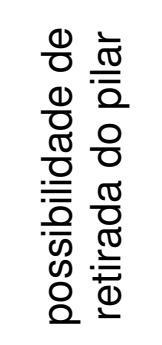 \\
\hline & 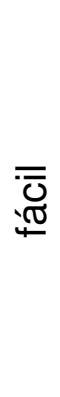 & $\begin{array}{l}\frac{\pi}{0} \\
\frac{\pi}{0} \\
\frac{0}{0} \\
\text { ह }\end{array}$ & 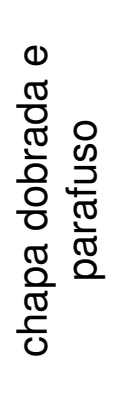 & $\begin{array}{l}\frac{\pi}{0} \\
\frac{\pi}{0} \\
\frac{0}{0} \\
\frac{O}{E}\end{array}$ & 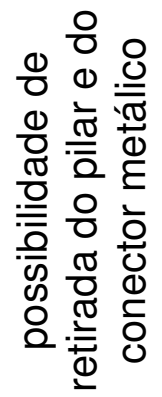 \\
\hline & $\begin{array}{l}\overline{\overline{0}} \\
\underset{\pi}{\pi}\end{array}$ & $\begin{array}{l}\overline{\overline{0}} \\
\text { 胥 }\end{array}$ & 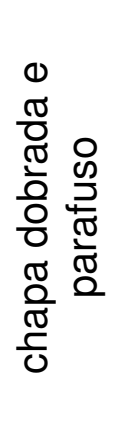 & 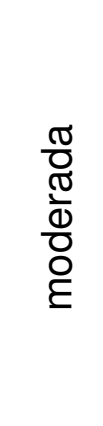 & 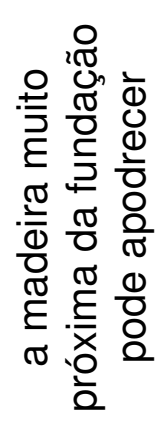 \\
\hline 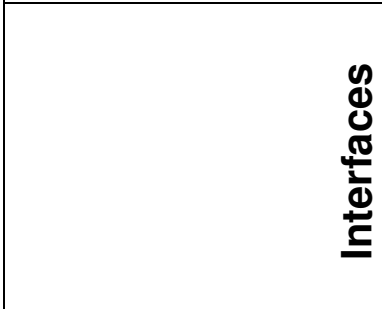 & 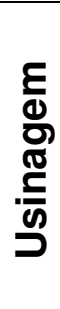 & 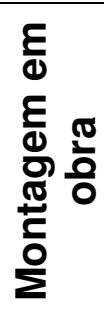 & 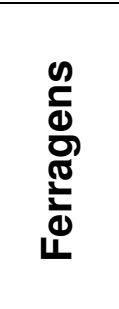 & 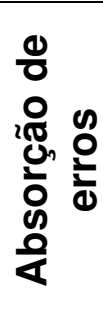 & 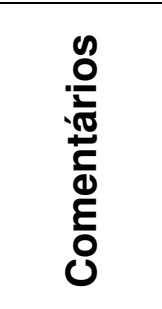 \\
\hline
\end{tabular}




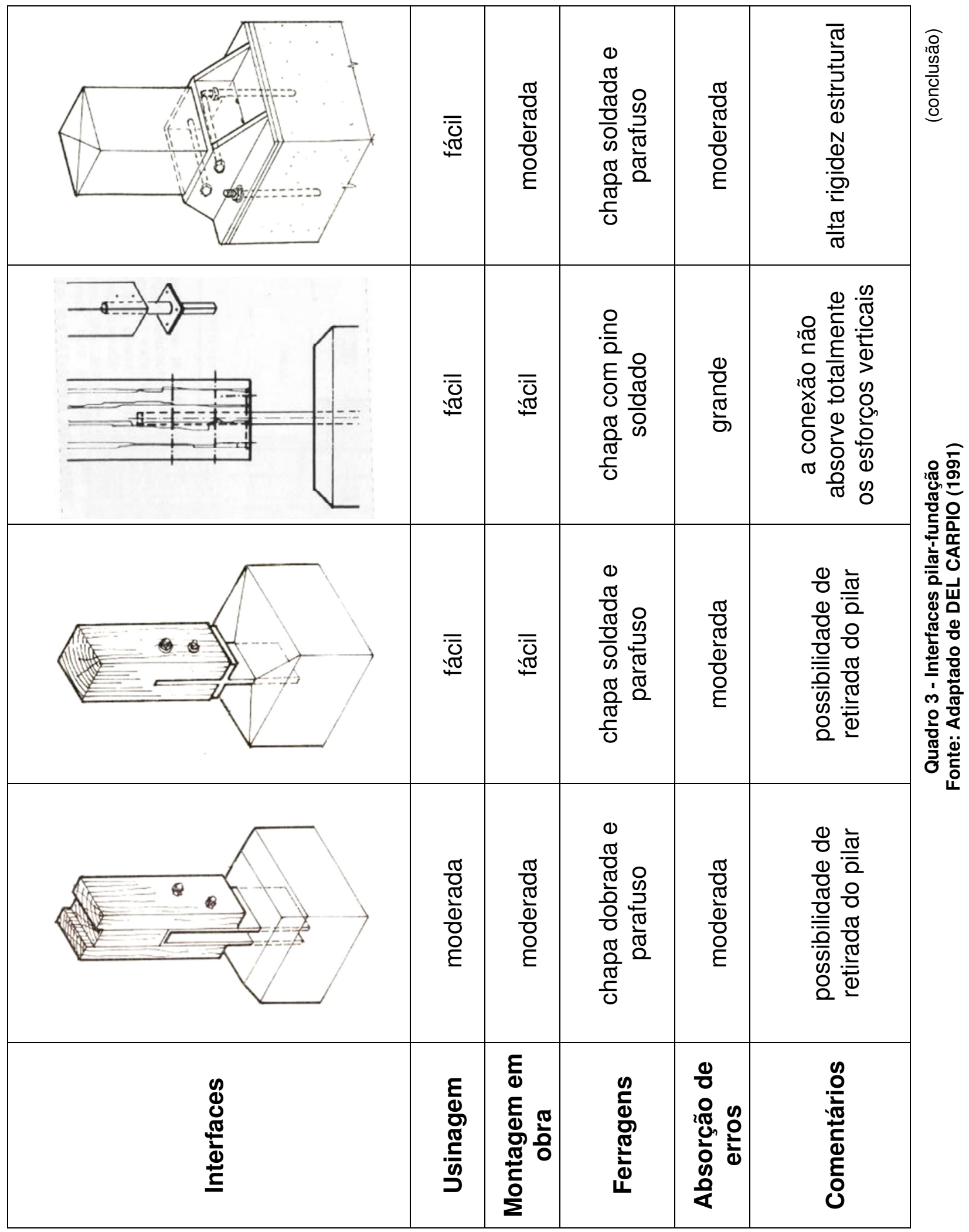




\subsubsection{Interfaces pilar-viga}

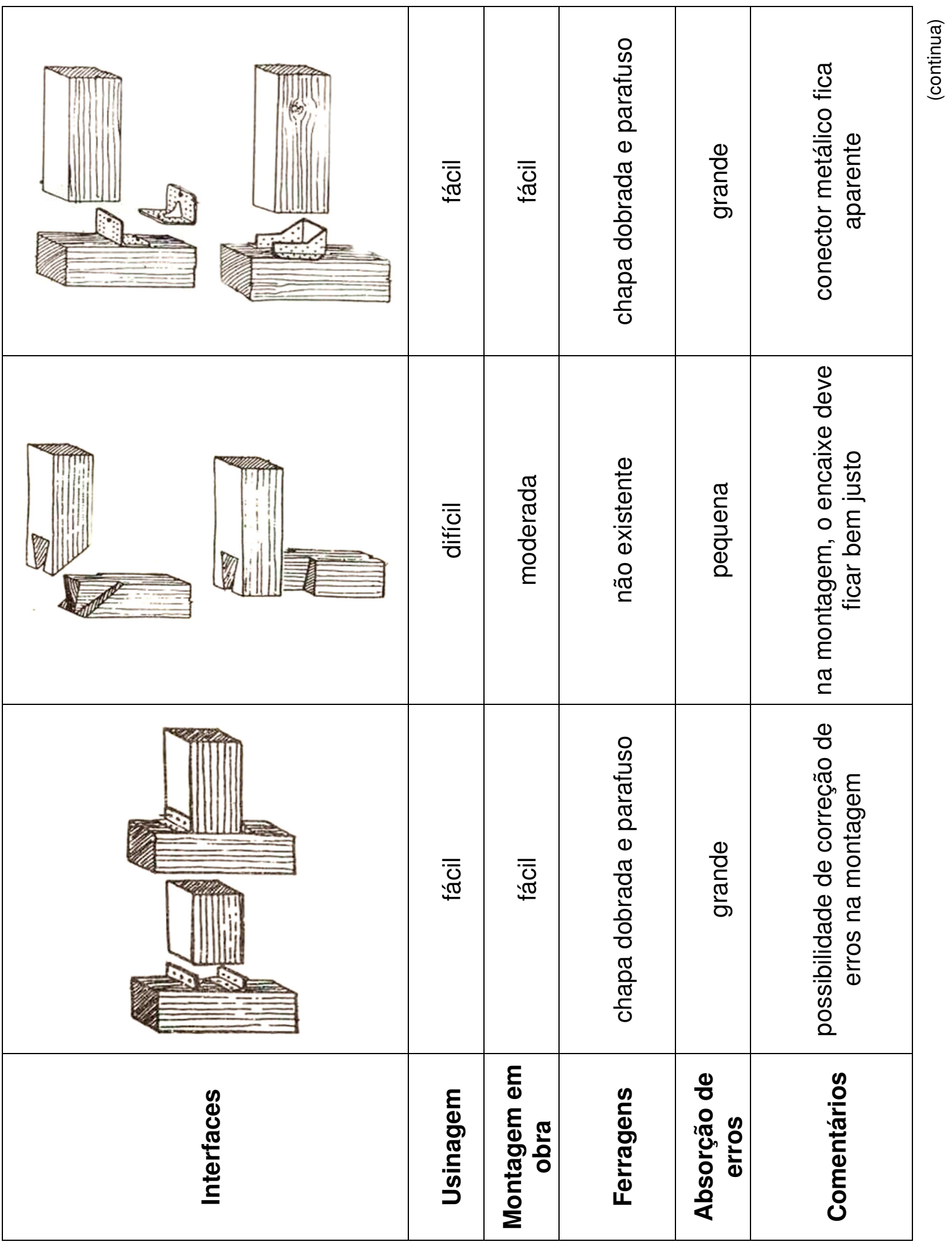




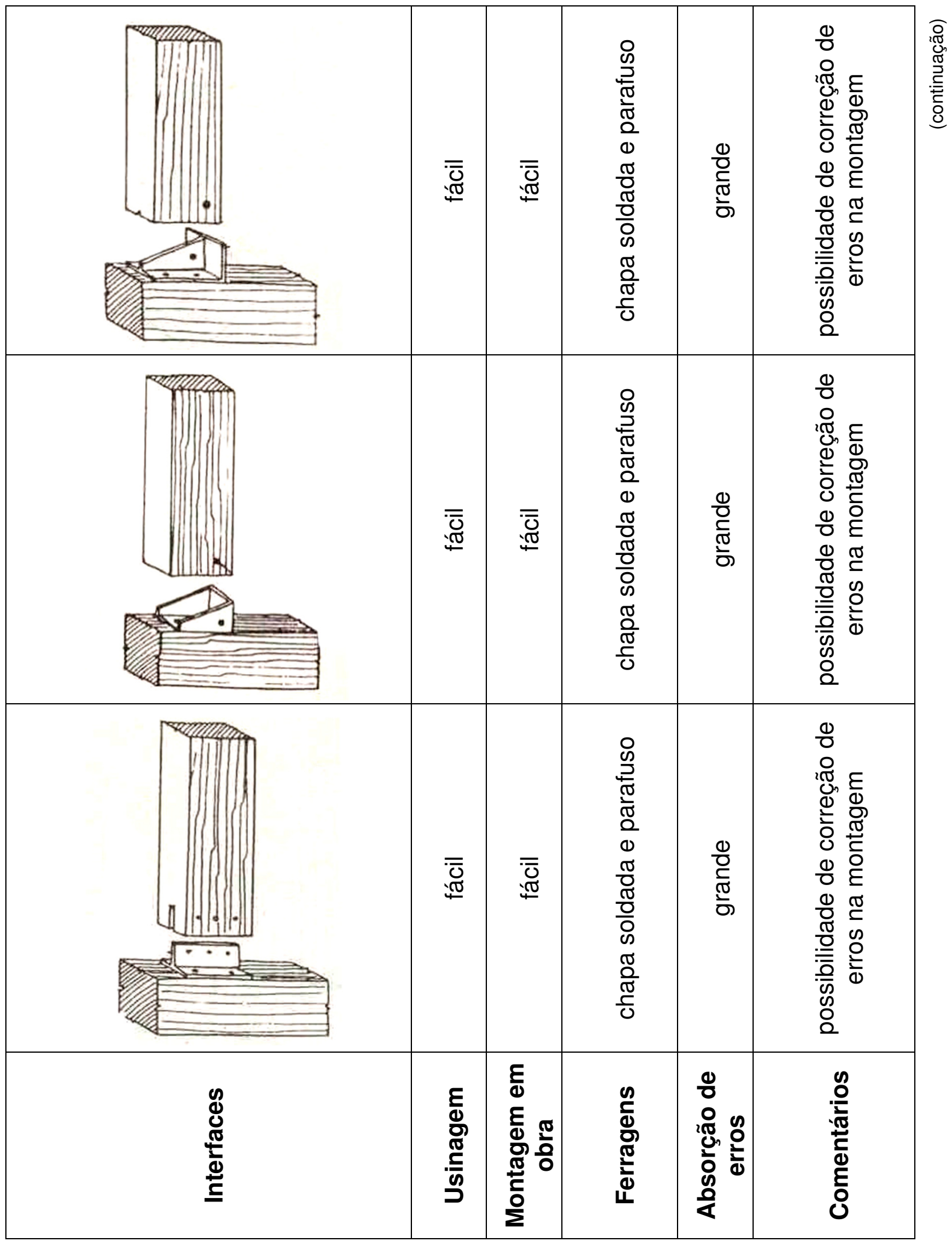




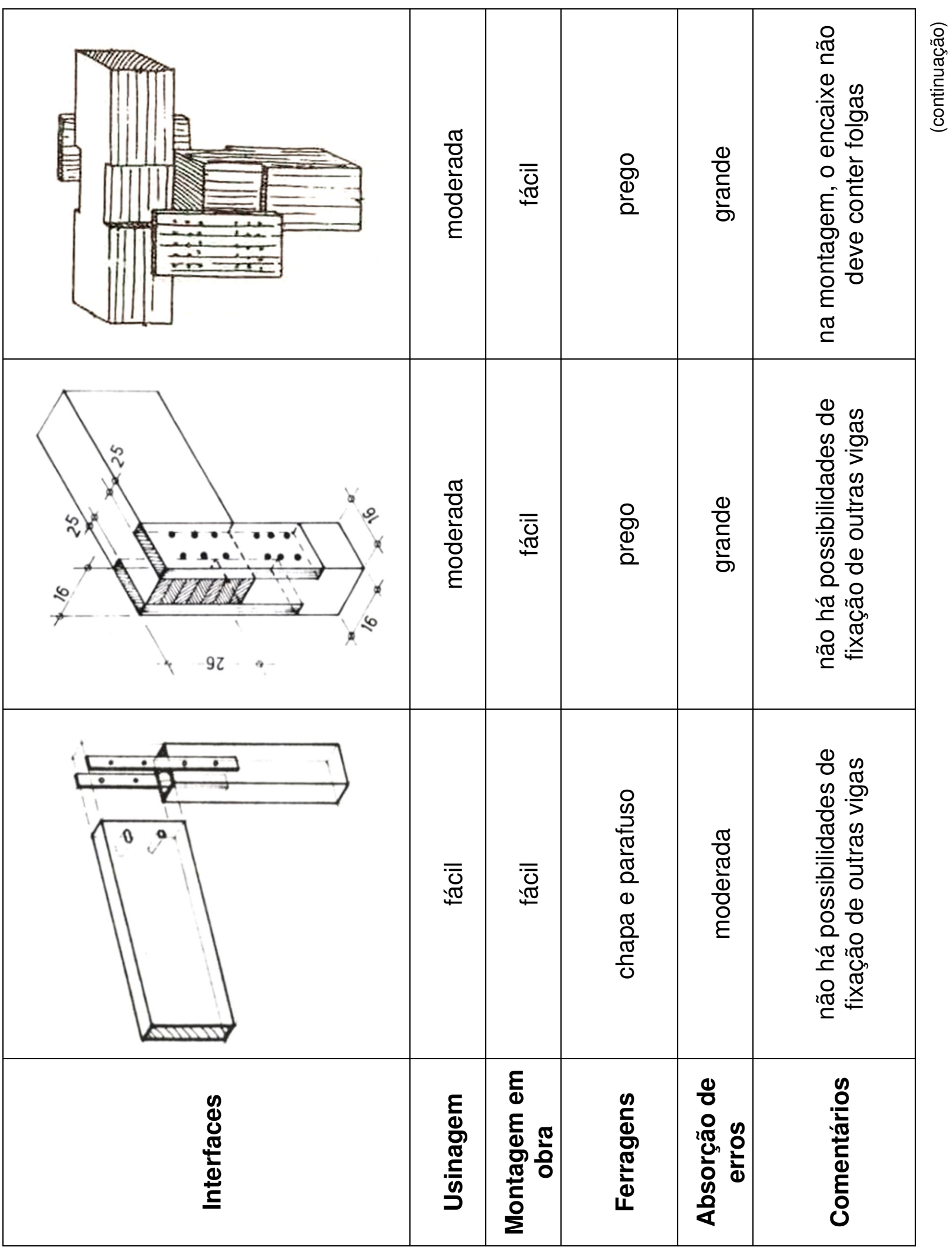




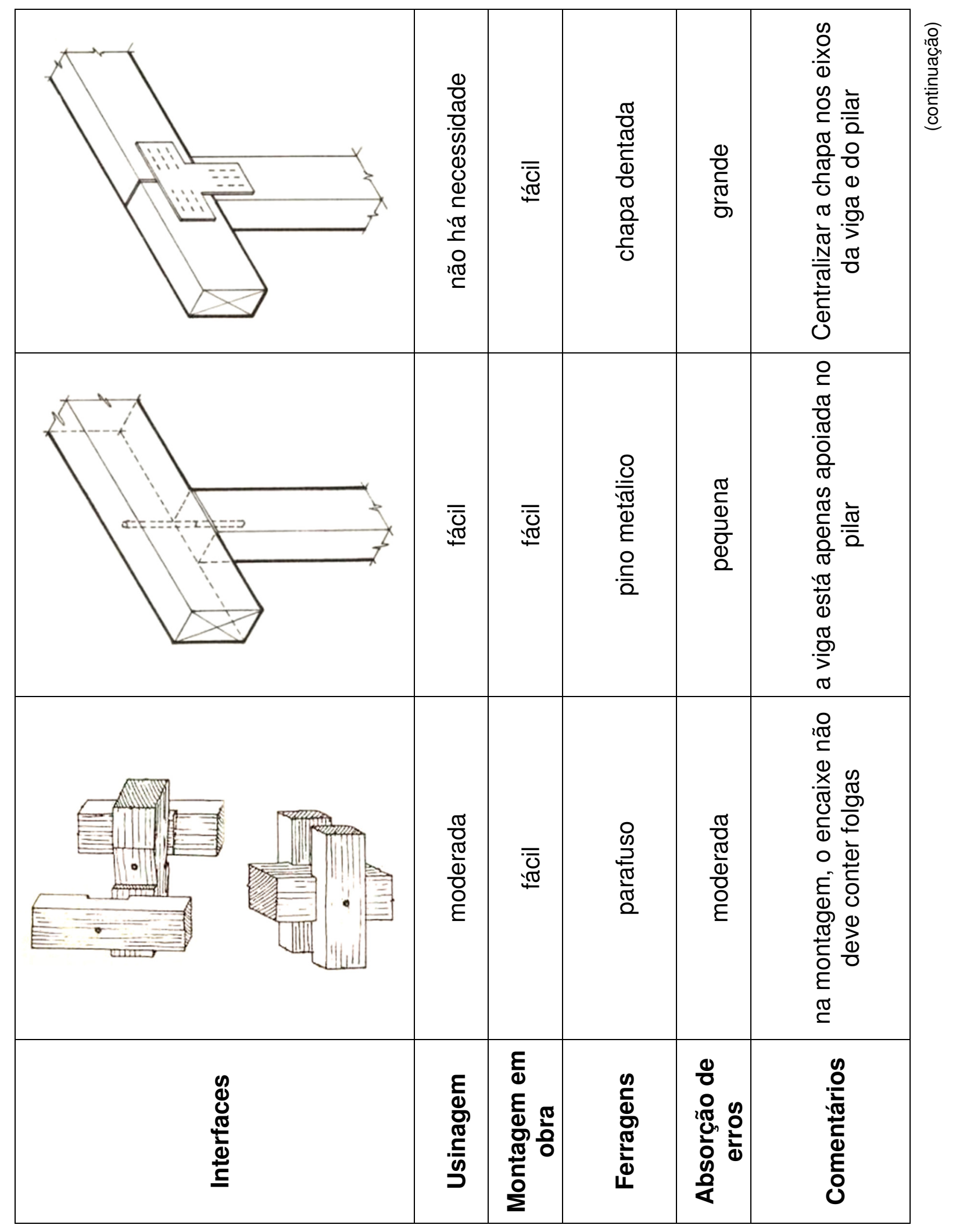




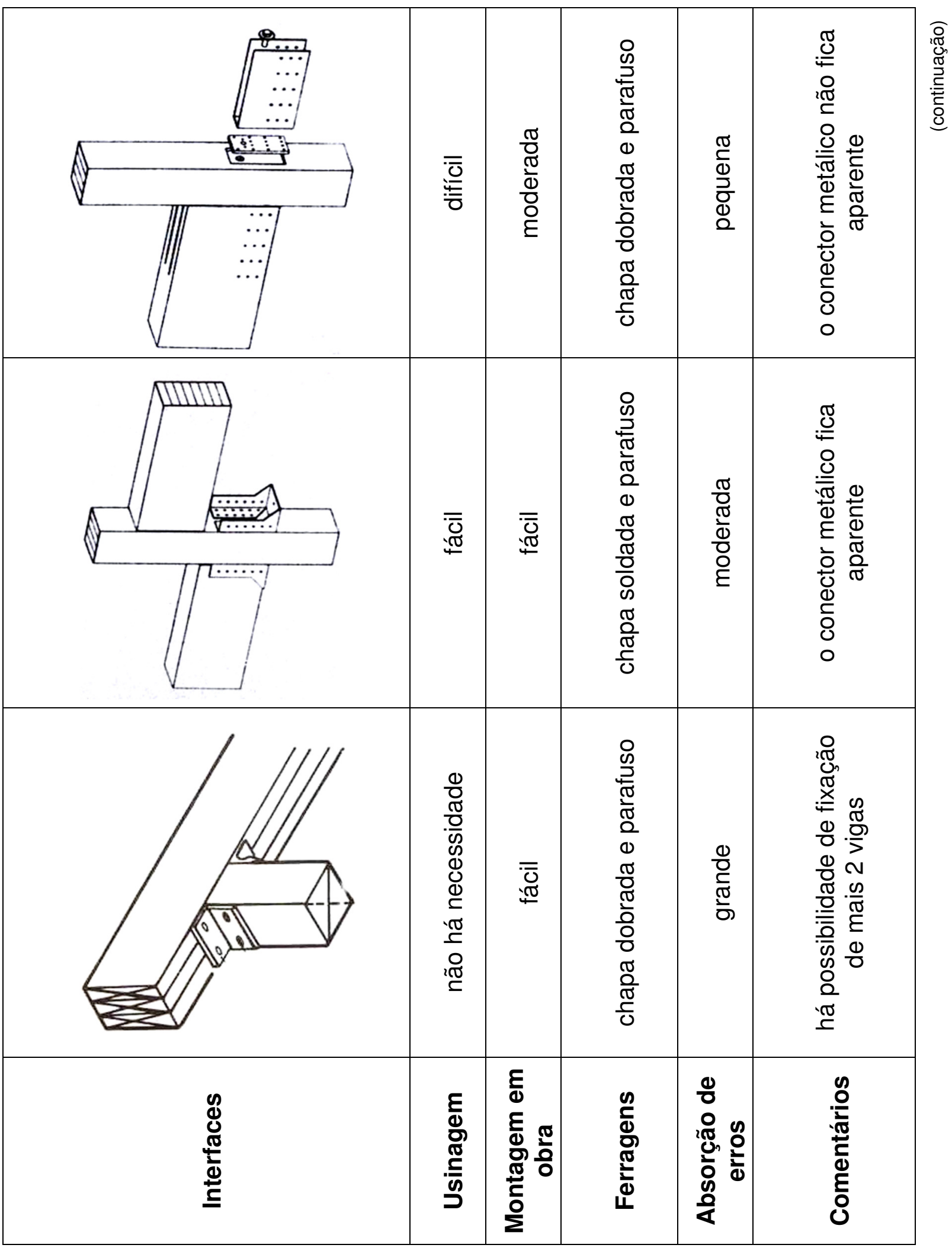




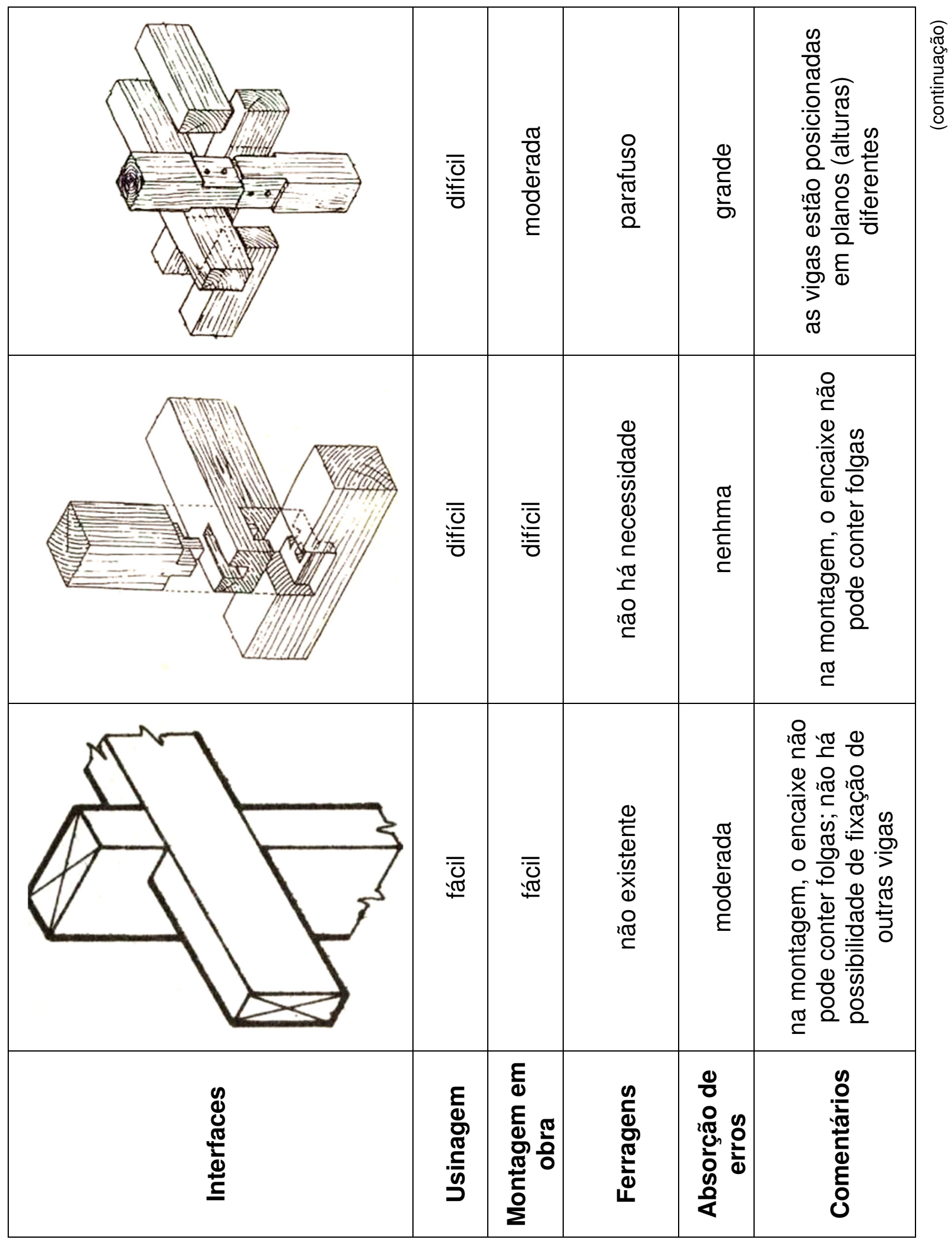




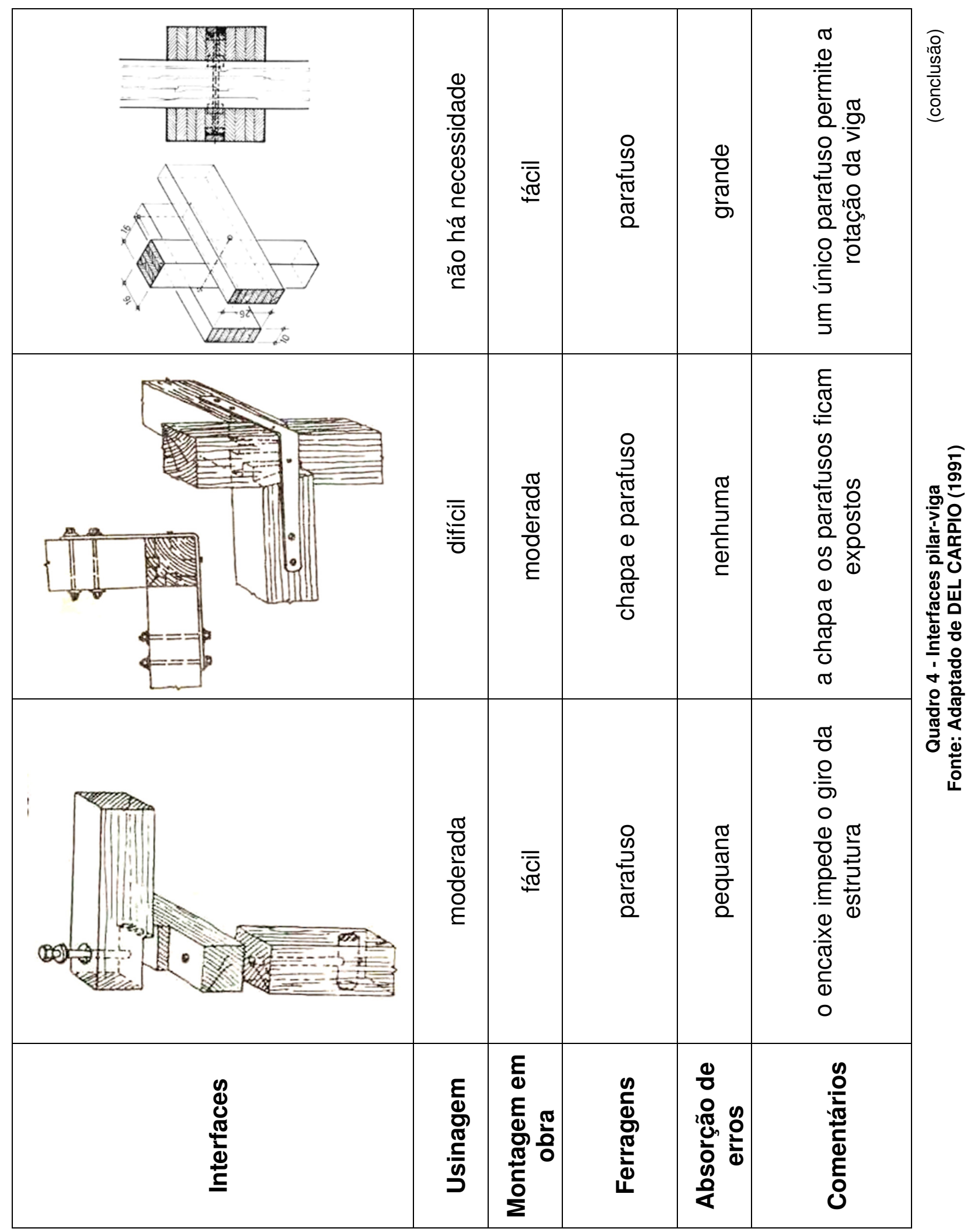




\subsubsection{Interfaces viga-viga}

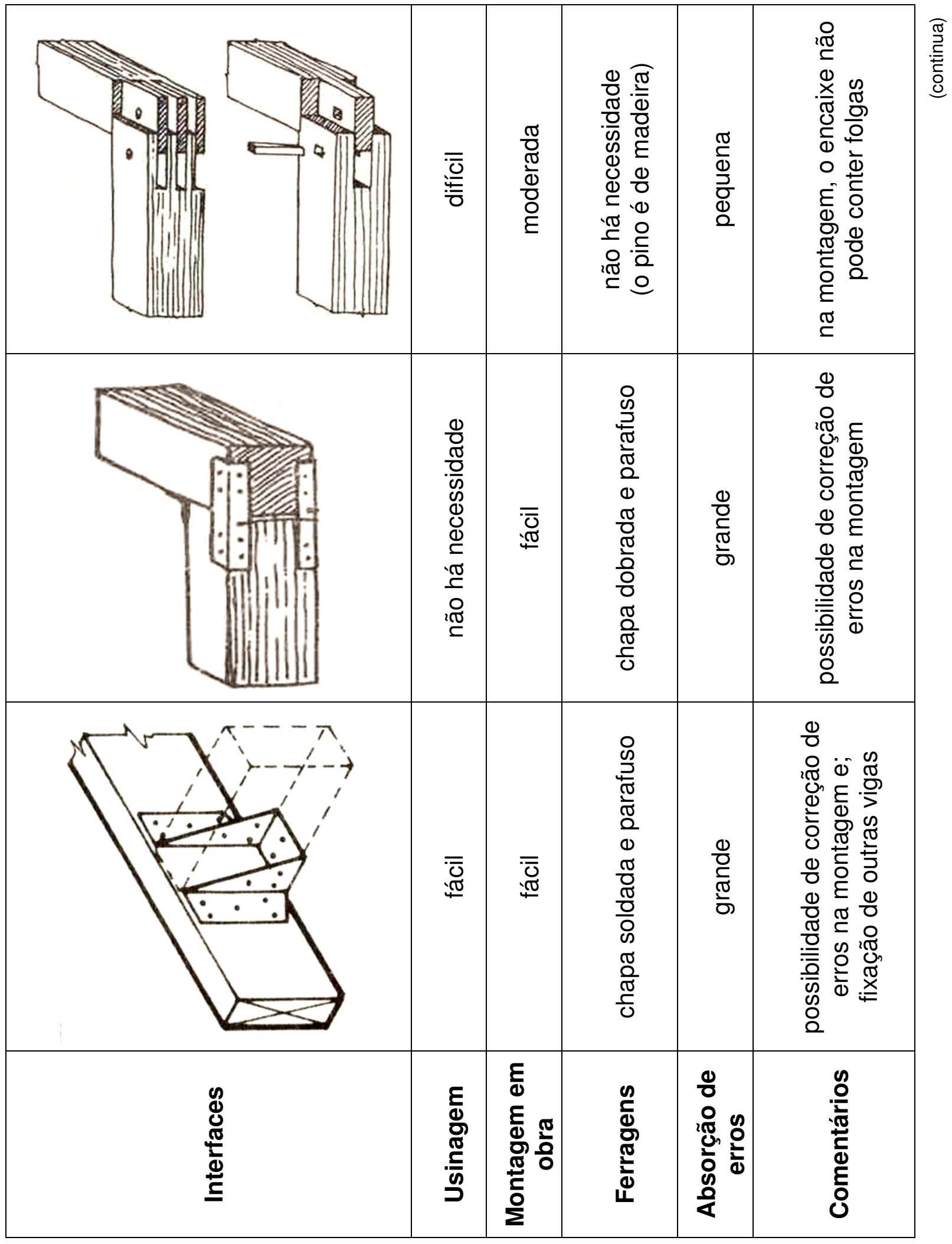




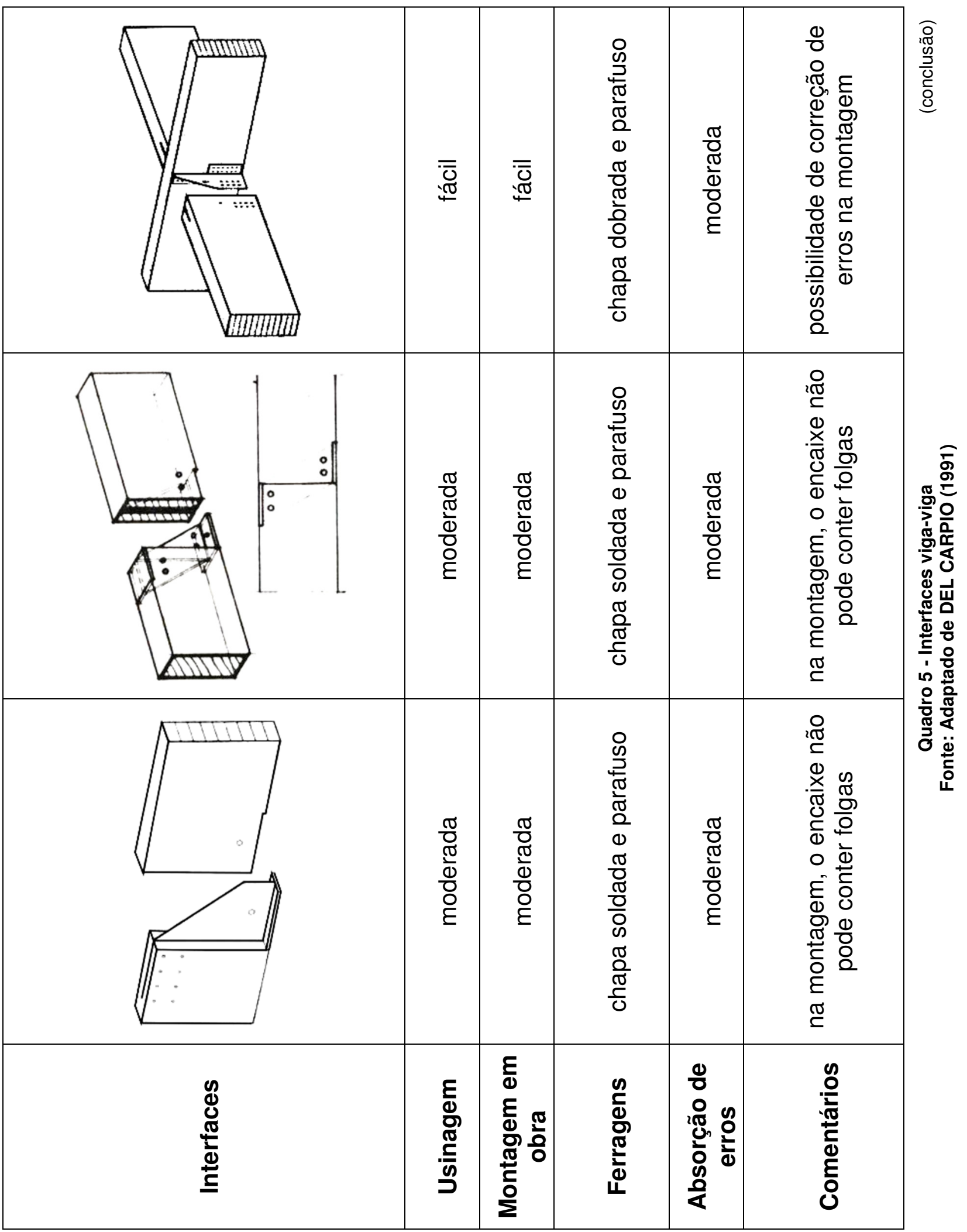




\section{PROPOSTAS DE INTERFACES E COMPONENTES ESTRUTURAIS EM MADEIRA}

Neste capítulo serão apresentados os projetos executivos de produção dos conectores metálicos, dos componentes estruturais de Eucalyptus e as interfaces entre pilar-fundação, pilar-viga e viga-viga propostas. As modelagens tridimensionais dos componentes e interfaces fazem parte do detalhamento proposto.

Ressalta-se que os componentes estruturais e interfaces apresentadas a seguir podem, perfeitamente, ser utilizadas para edificações que utilizem madeira nativa proveniente de áreas de manejo certificado e/ou de áreas legalizadas, em locais onde sua utilização satisfaça os critérios de sustentabilidade apresentados ao longo da presente pesquisa.

As interfaces propostas têm como intuito minimizar a realização de usinagens complexas nas unidades de pré-fabricação e grandes ajustes em obra (que requerem um gasto energético adicional); minimizar a geração de resíduos de madeira; contribuir para uma maior facilidade de transporte das peças e a otimização da montagem sem que haja necessidade de mão de obra especializada.

Para tanto, as interfaces contam com conectores metálicos galvanizados a fogo, sendo empregados parafusos passantes e parafusos tipo soberbo, dependendo da situação de cada ligação. A inserção do conector diminui a necessidade de complexas usinagens e encaixes nas peças de madeira.

Destaca-se o fato de que foram atribuídas seções aos componentes de madeira somente para possibilitar a elaboração dos desenhos. De acordo com as especificidades do projeto arquitetônico e após a elaboração de cálculo estrutural é que as peças devem ter suas dimensões finais definidas, sendo que, nos projetos a seguir, odas as seções referem-se a peças usinadas e aparelhadas.

Outro fato que merece destaque é que os vãos de projeto podem ser definidos de forma a otimizar a montagem dos componentes e evitar a execução de emendas das vigas ao longo de seu comprimento.

Ressalta-se também a importância da utilização de produtos preservantes nas peças de madeira através do pincelamento, no intuito de prevenir 0 ataque de brocas e cupins, bem como o aparecimento de fungos manchadores. Esse processo deve ser repetido após a verificação do aparecimento de fendas nas peças de 
madeira, devido à sua secagem e movimentações estruturais, bem como nas regiões que sofreram usinagens, mais propícias aos referidos ataques.

Em todas as folhas de projeto apresentadas a seguir, ao seu lado direito é apresentada uma tabela com um desenho das peças e componentes metálicos utilizados, além de suas características, dimensões e quantidade utilizada na interface, exceto no projeto de produção dos pilares compostos, onde são apresentadas as peças de madeira que os compõem.

As texturas utilizadas nos modelos tridimensionais foram adotadas de forma a realçar os detalhes e diferenciar as peças de madeira e metálicas que compõem as interfaces, não representando, portanto, a textura original do Eucalyptus.

\subsection{PROJETOS DE PRODUÇÃO}

\subsubsection{Componentes Metálicos}

Nesta etapa serão apresentados os projetos de produção dos componentes metálicos utilizados nas interfaces propostas.

Destaca-se a padronização e pouca variabilidade dos componentes metálicos, com intuito de facilitar a produção dos mesmos e consequentemente a posterior montagem das interfaces.

Embora os conectores possuam características próprias e algumas especificidades, o processo de produção não apresenta dificuldade, visto que as empresas especializadas possuem equipamentos e processos automatizados para a produção dos referidos componentes.

Salienta-se que as seções e espessuras dos componentes metálicos podem variar de acordo com o dimensionamento da estrutura.

Os desenhos apresentados são os seguintes:

- Conector Metálico Pilar-fundação (T1)

- Conector Metálico Pilar-fundação (T2)

- Conector Metálico Pilar-viga (T3-50)

- Conector Metálico Pilar-viga (T3-60) 

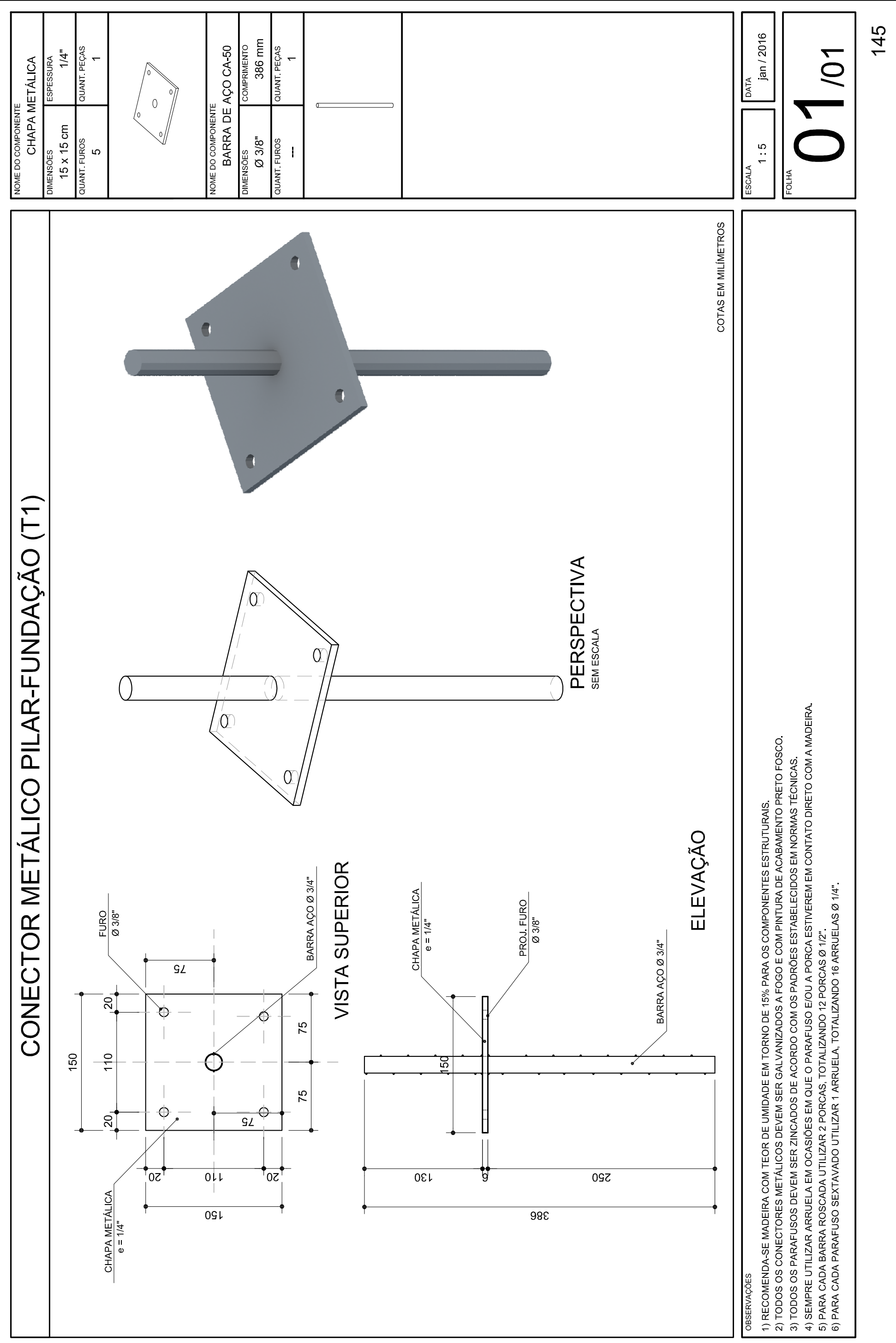

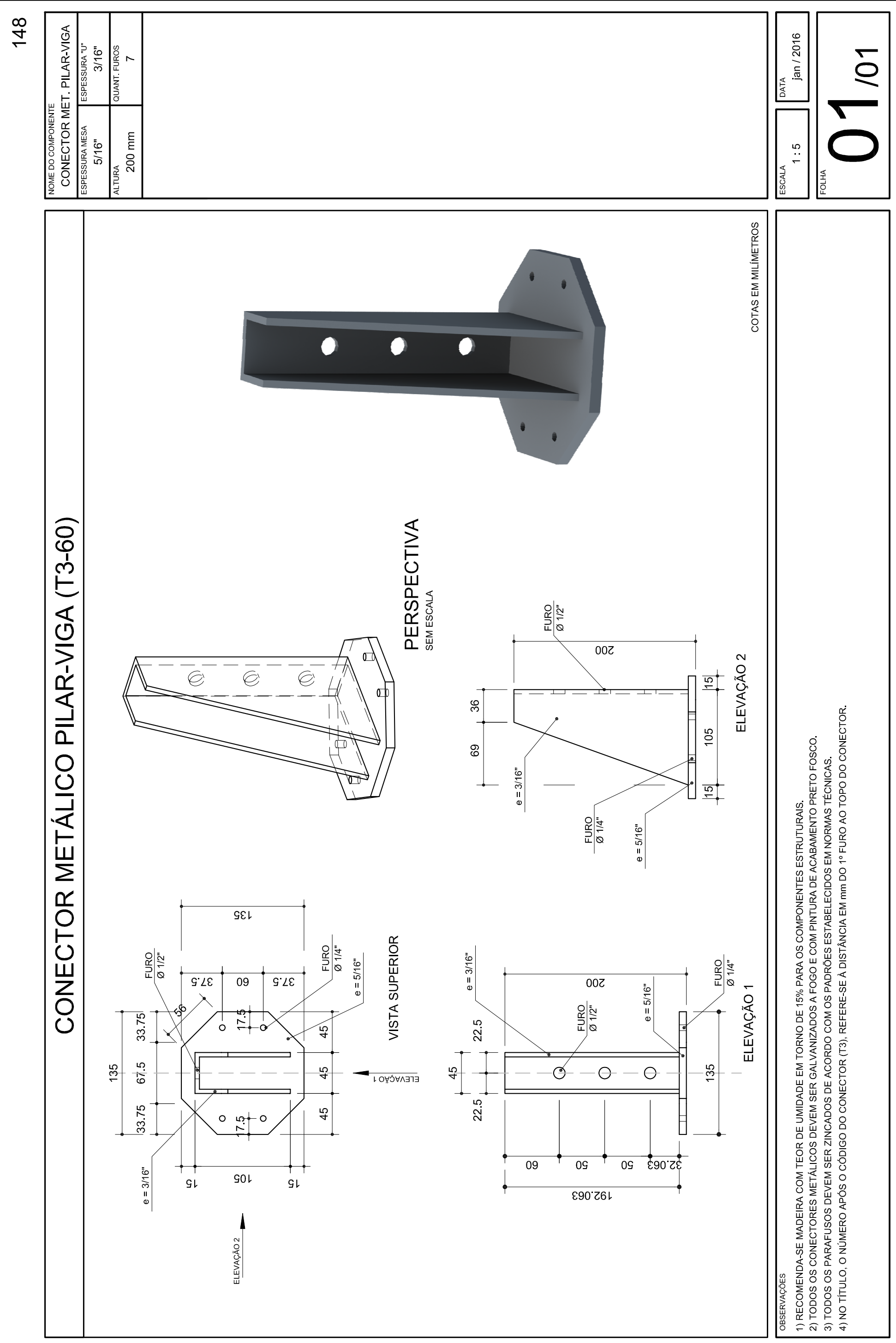


\subsubsection{Componentes de Madeira}

Nesta etapa serão apresentados os projetos de produção dos componentes estruturais de madeira utilizados nas interfaces propostas, sendo eles, pilares compostos, vigas simples e vigas simples combinadas, para utilização como vigas duplas.

Destaca-se a padronização e pouca variabilidade dos componentes de madeira, com intuito de facilitar a produção dos mesmos e consequentemente a posterior montagem das interfaces.

Ressalta-se que a usinagem da base das vigas duplas podem ser facilmente executadas com serra circular de bancada e/ou com equipamentos manuais simples, não requerendo uma mão-de-obra especializada para ser executada.

Salienta-se que, assim como no caso dos componentes metálicos, as seções das peças de madeira podem variar de acordo com o dimensionamento da estrutura.

Os desenhos apresentados são os seguintes:

- Pilar Composto (para uso na interface Fundação 1)

- Pilar Composto (para uso na interface Fundação 2)

- Viga Dupla 22

Os pilares compostos foram adotados no intuito de se utilizar peças com dimensões reduzidas, possibilizando uma maior otimização no desdobro da tora devido ao fato da madeira de florestas plantadas possuírem seções reduzidas, quando comparadas à madeira de florestas nativas. 

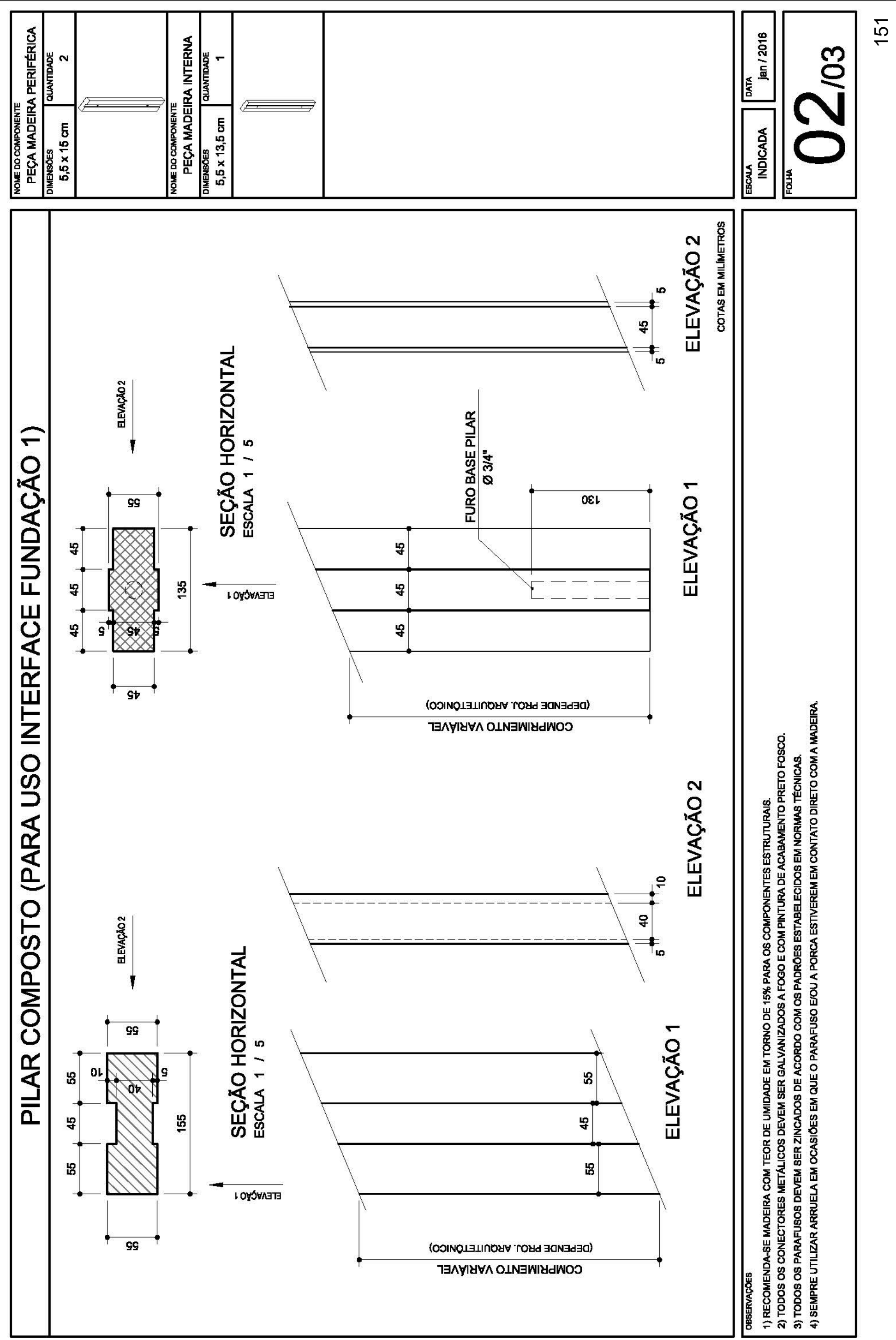

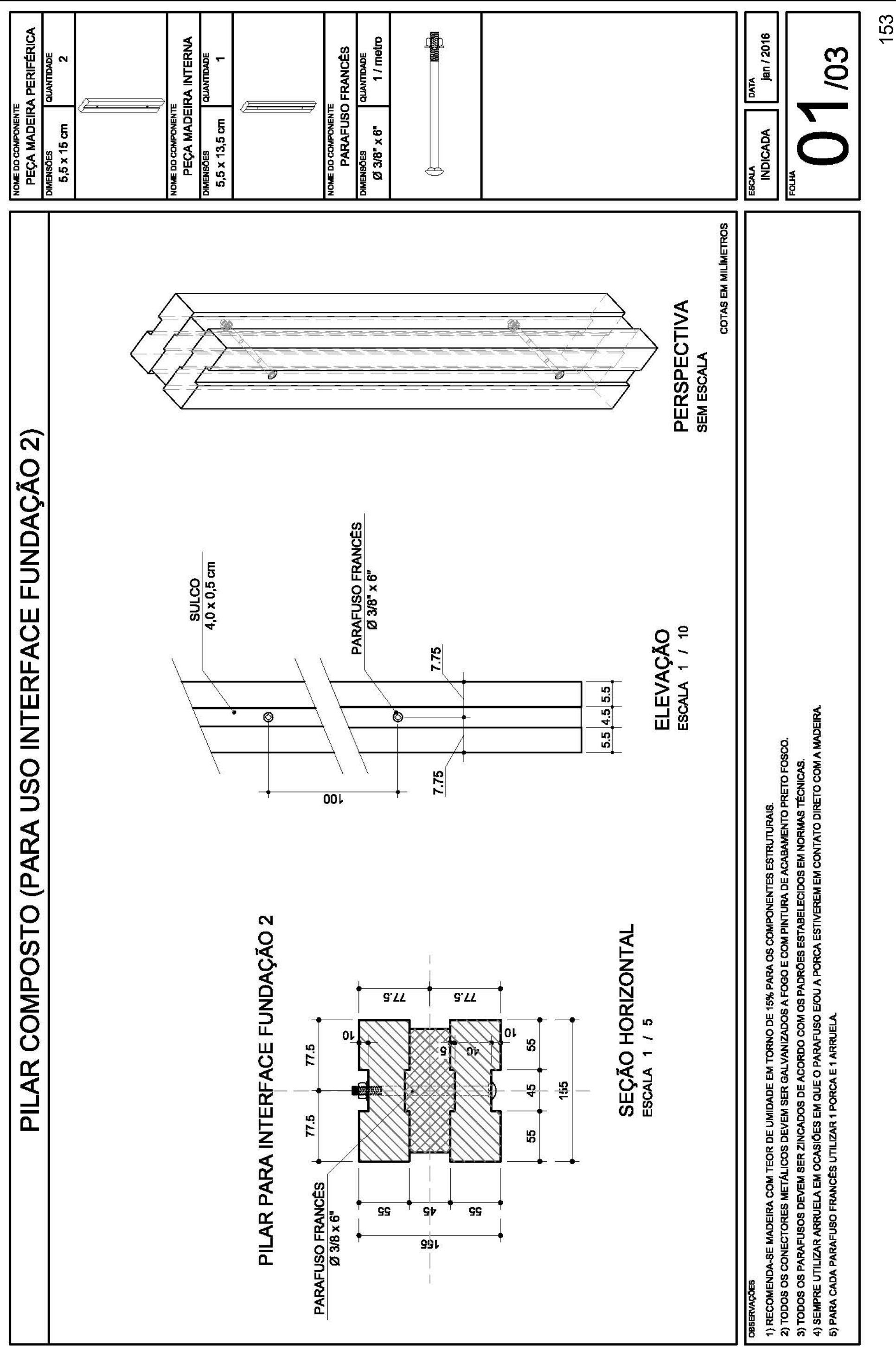

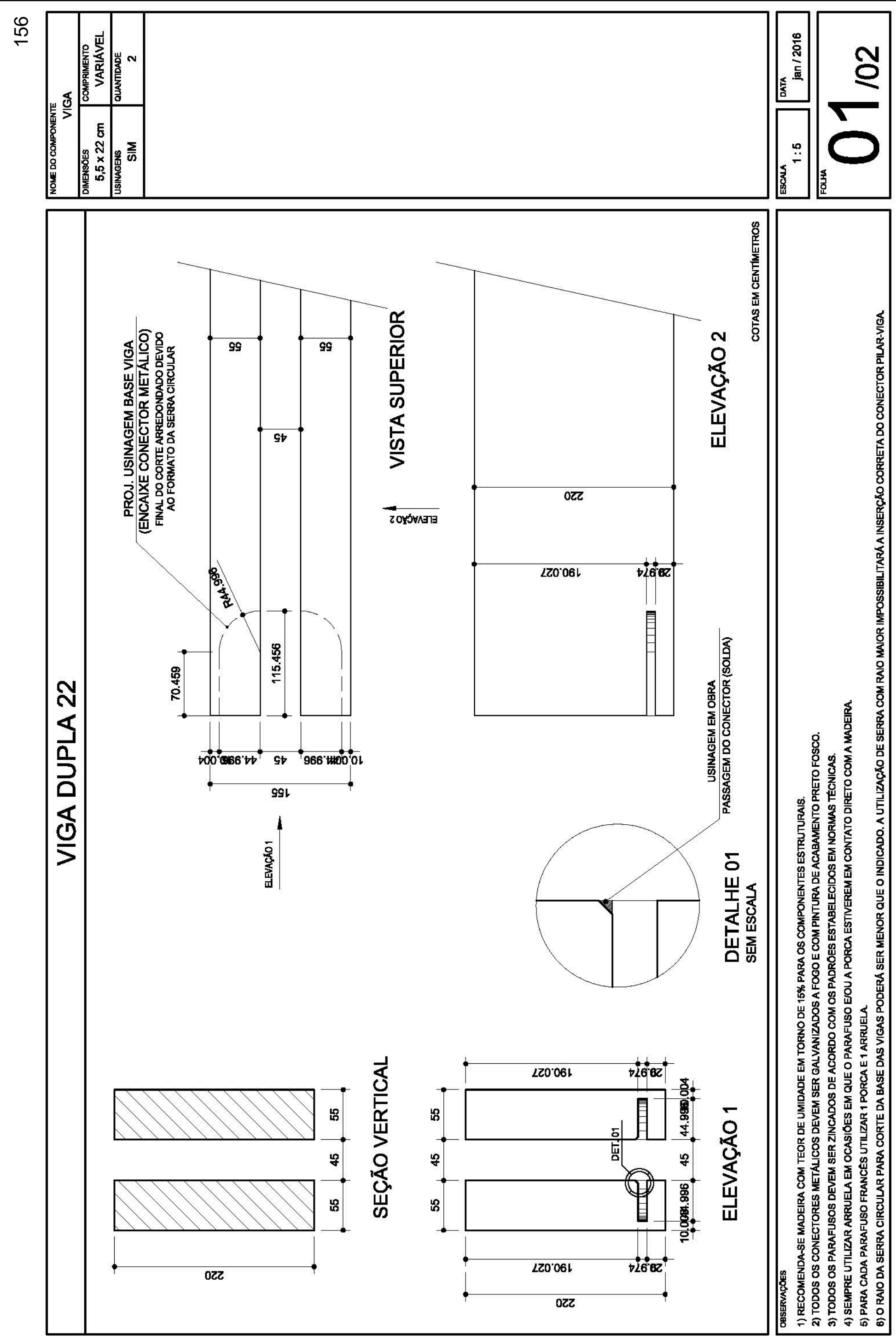

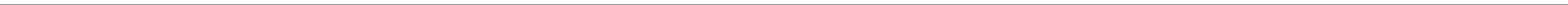


\subsection{PROJETOS DAS INTERFACES}

Nesta etapa serão apresentados os projetos das interfaces entre os componentes estruturais de madeira, sendo elas, Interfaces pilar-fundação e pilarviga com diversas variações.

Destaca-se, nesta etapa, a baixa complexidade de montagem das interfaces, possibilitando a execução por profissionais que não possuem uma grande qualificação para trabalhar com a madeira, pois como pode ser observado no projeto de produção dos componentes estruturais, as peças já saem das unidades de préfabricação com a furação para posicionamento dos conectores metálicos principais, sendo necessário somente a execução de furação secundária.

Foram atribuídas seções aos componentes de madeira somente para possibilitar a elaboração dos desenhos. De acordo com as especificidades do projeto arquitetônico e após a elaboração de cálculo estrutural é que as peças devem ter suas dimensões finais definidas.

\subsubsection{Interfaces Pilar-Fundação}

Serão apresentadas duas possibilidades de interface entre pilar e fundação, com a utilização de dois conectores metálicos diferentes, que podem ser adotados de acordo as seções finais, tanto das peças de madeira quanto dos pilaretes de fundação. 

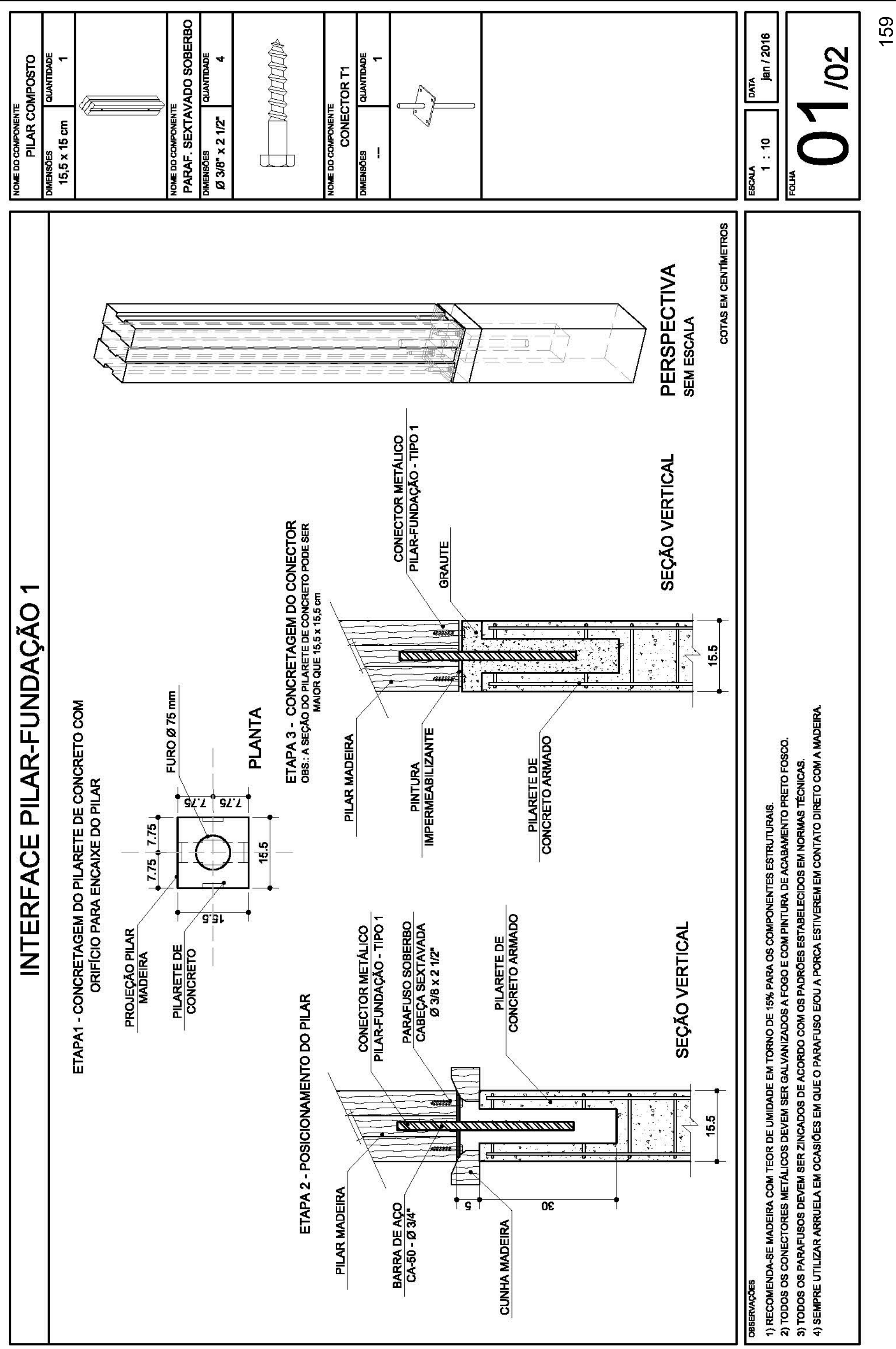

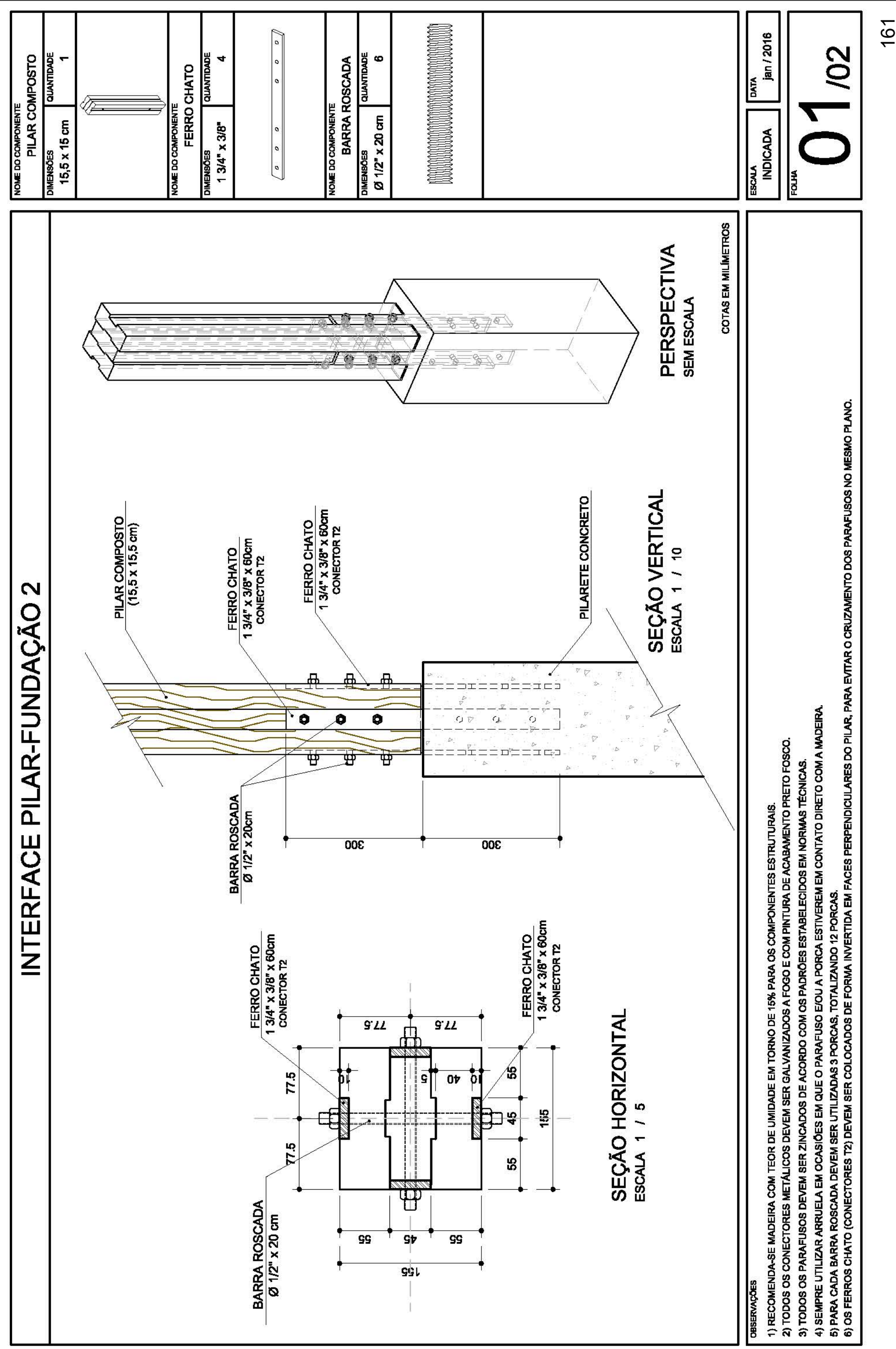

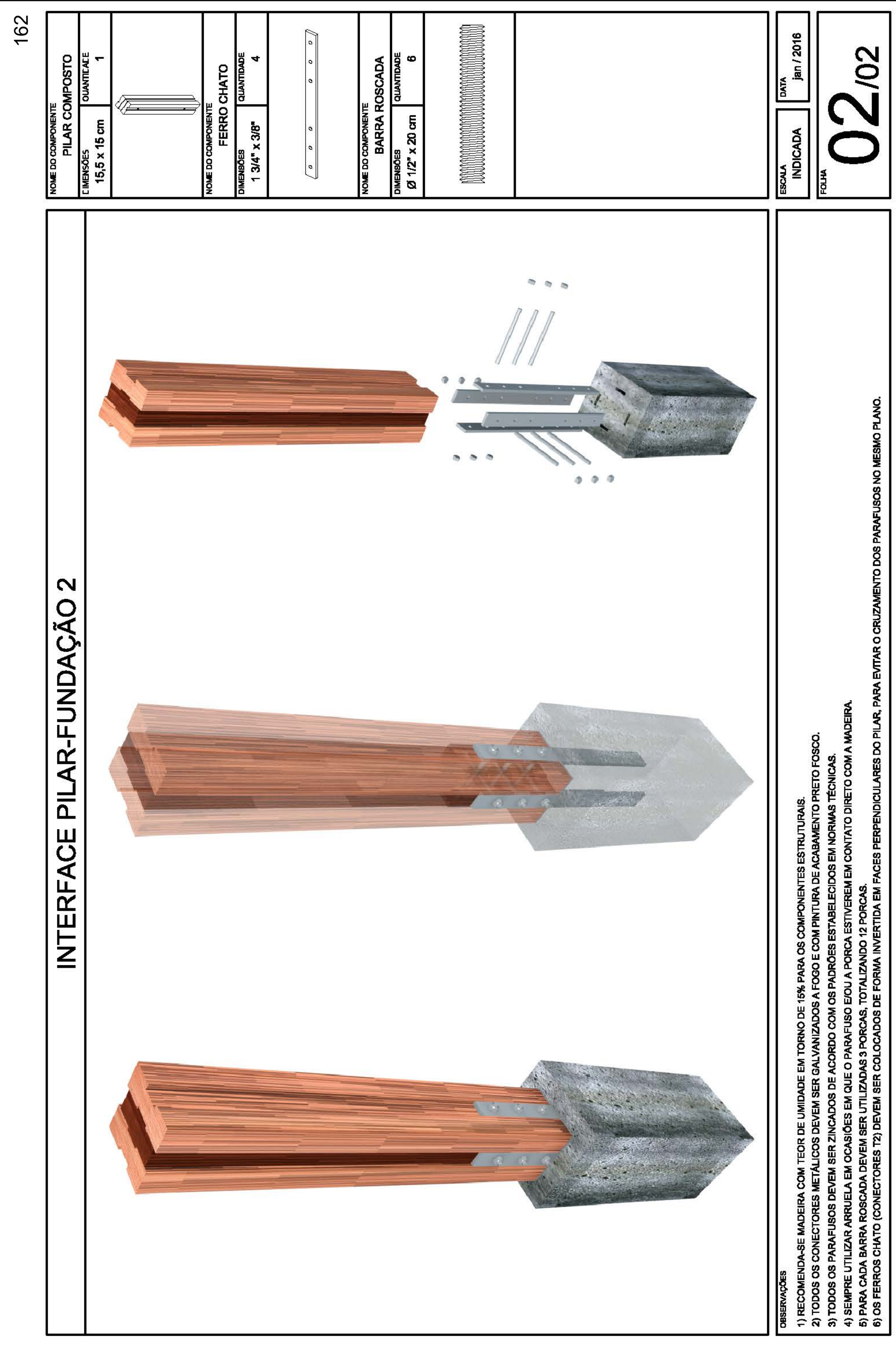


\subsubsection{Interfaces Pilar-viga}

Para todas as interfaces desta etapa foram adotados o pilar composto e as vigas duplas. Serão apresentadas diversas variações no que diz respeito á quantidade de vigas que se conectam ao pilar e o tipo de conexão adotada, através dos conectores metálicos ou simplesmente pela passagem da viga em recortes no topo dos pilares, como no caso de vigas em balanço.

Para a união das peças, além dos conectores metálicos foram utilizadas barras roscadas com porcas e arruelas, parafusos passantes, parafusos franceses e parafusos de rosca soberba, dependendo do caso.

Os projetos apresentados são os seguintes:

- Interface pilar-4 vigas duplas;

- Interface pilar-3 vigas duplas;

- Interface pilar-3 vigas duplas (1 passante e em balanço com mão francesa);

- Interface pilar-2 vigas duplas;

- Interface pilar-2 vigas duplas (1 passante e em balanço com mão francesa);

- Interface pilar-2 vigas duplas de canto. 

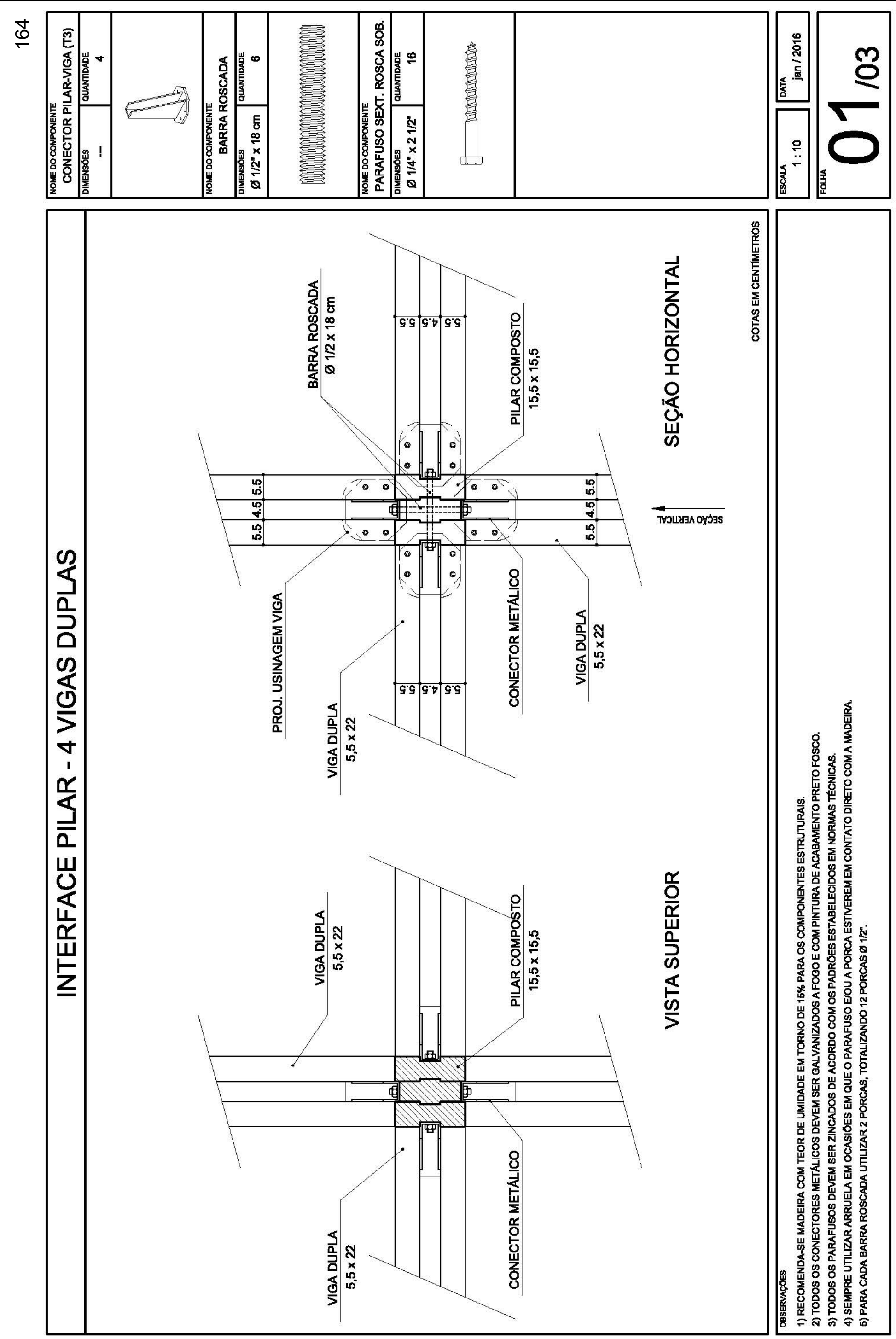


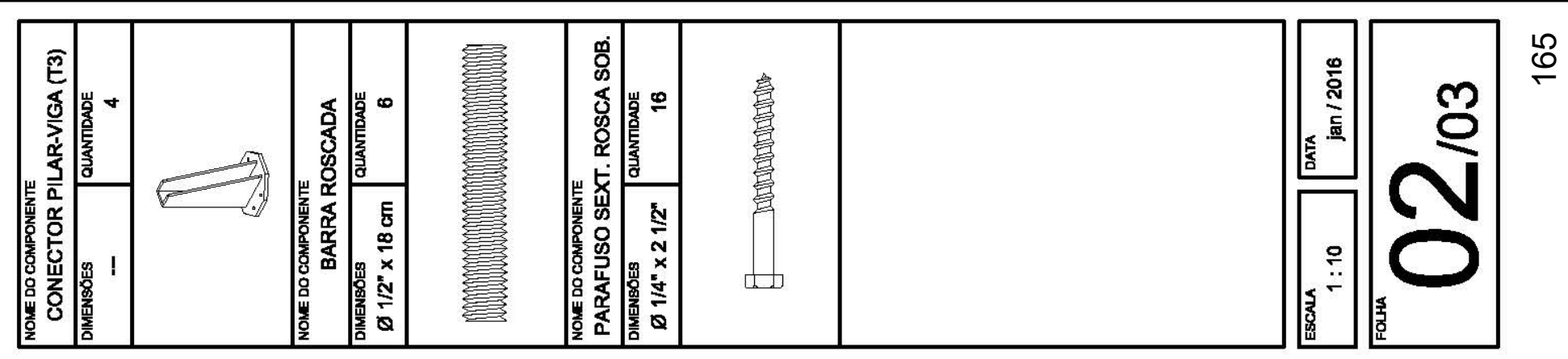

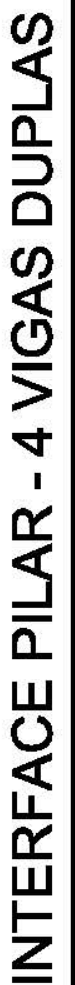
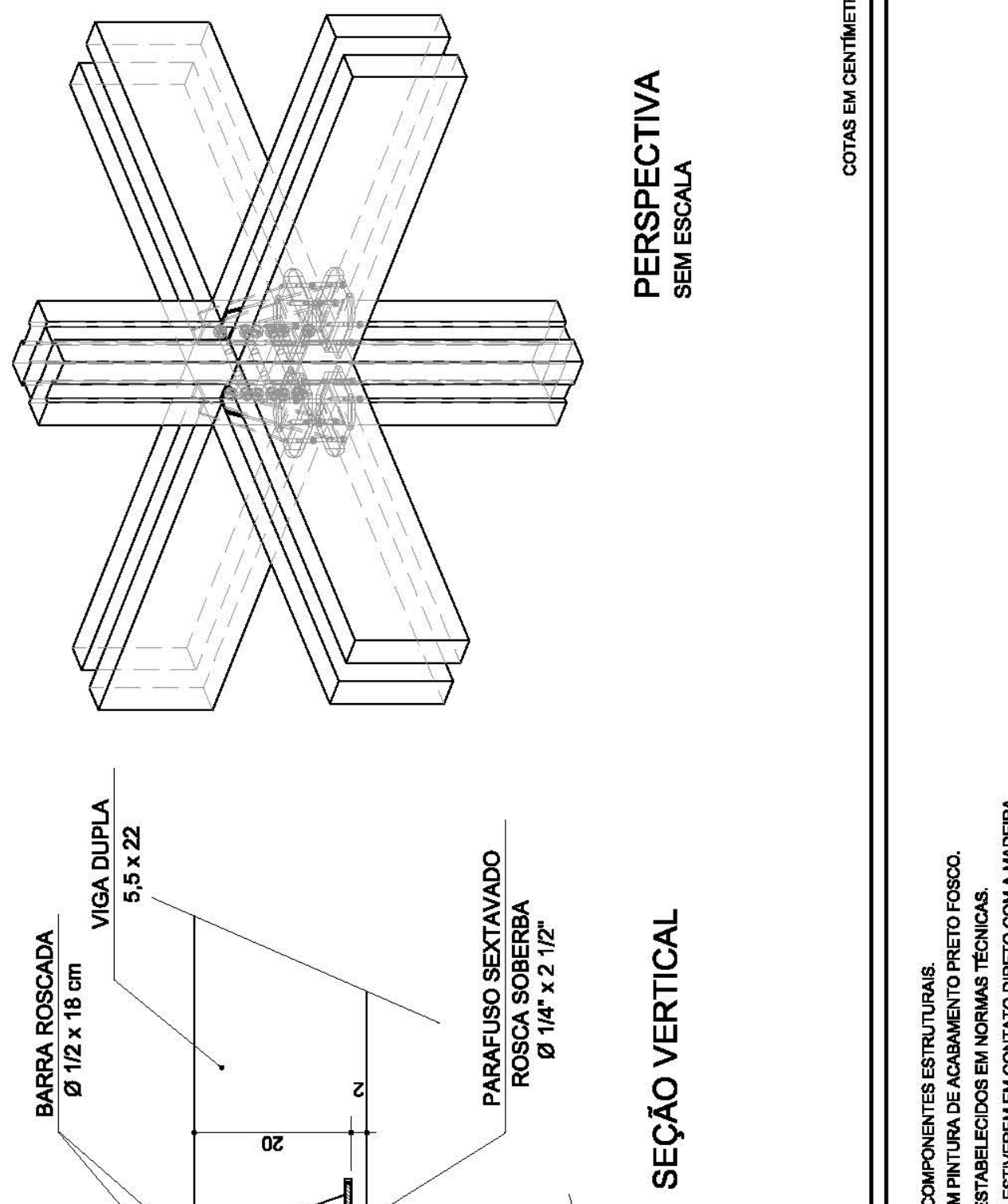

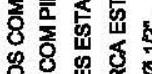

5.

和

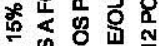

뗭 홍용 8

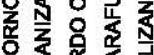

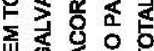

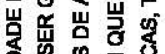

춘

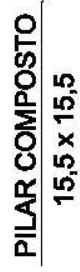

崫

क ज

㟧和

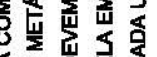

员证

슨

తิ 


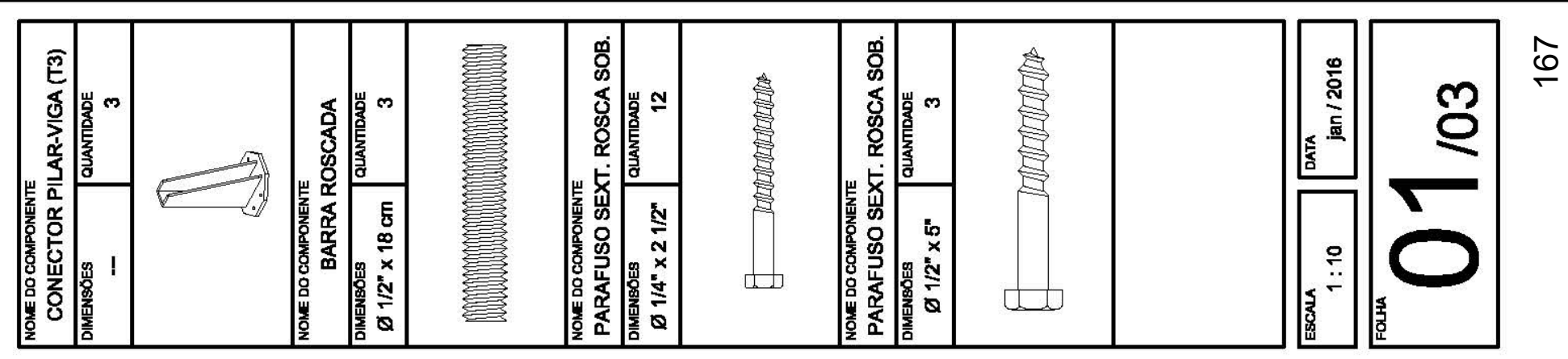

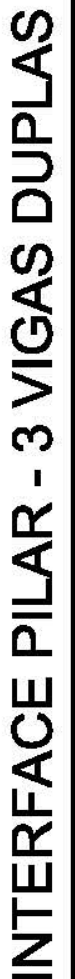
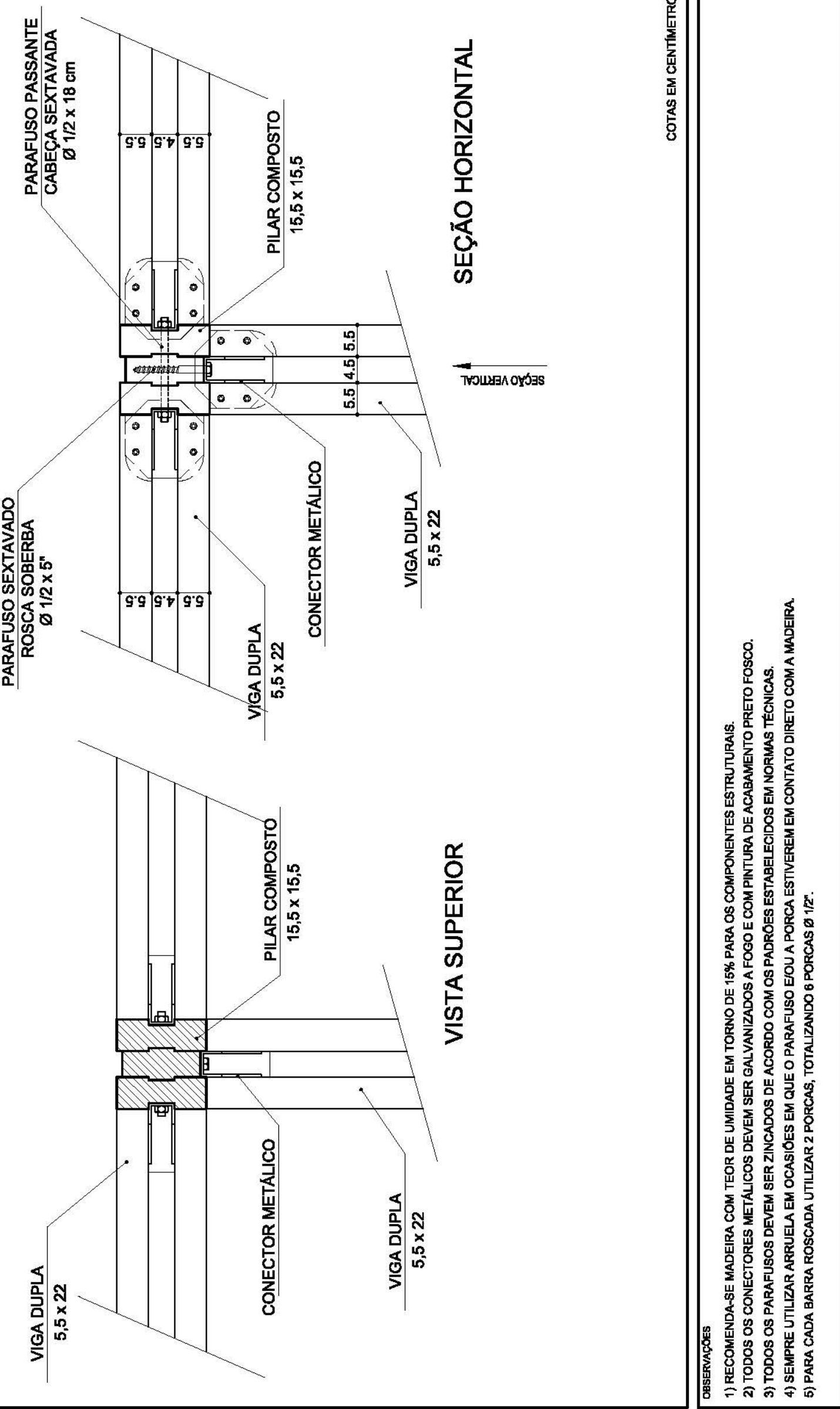

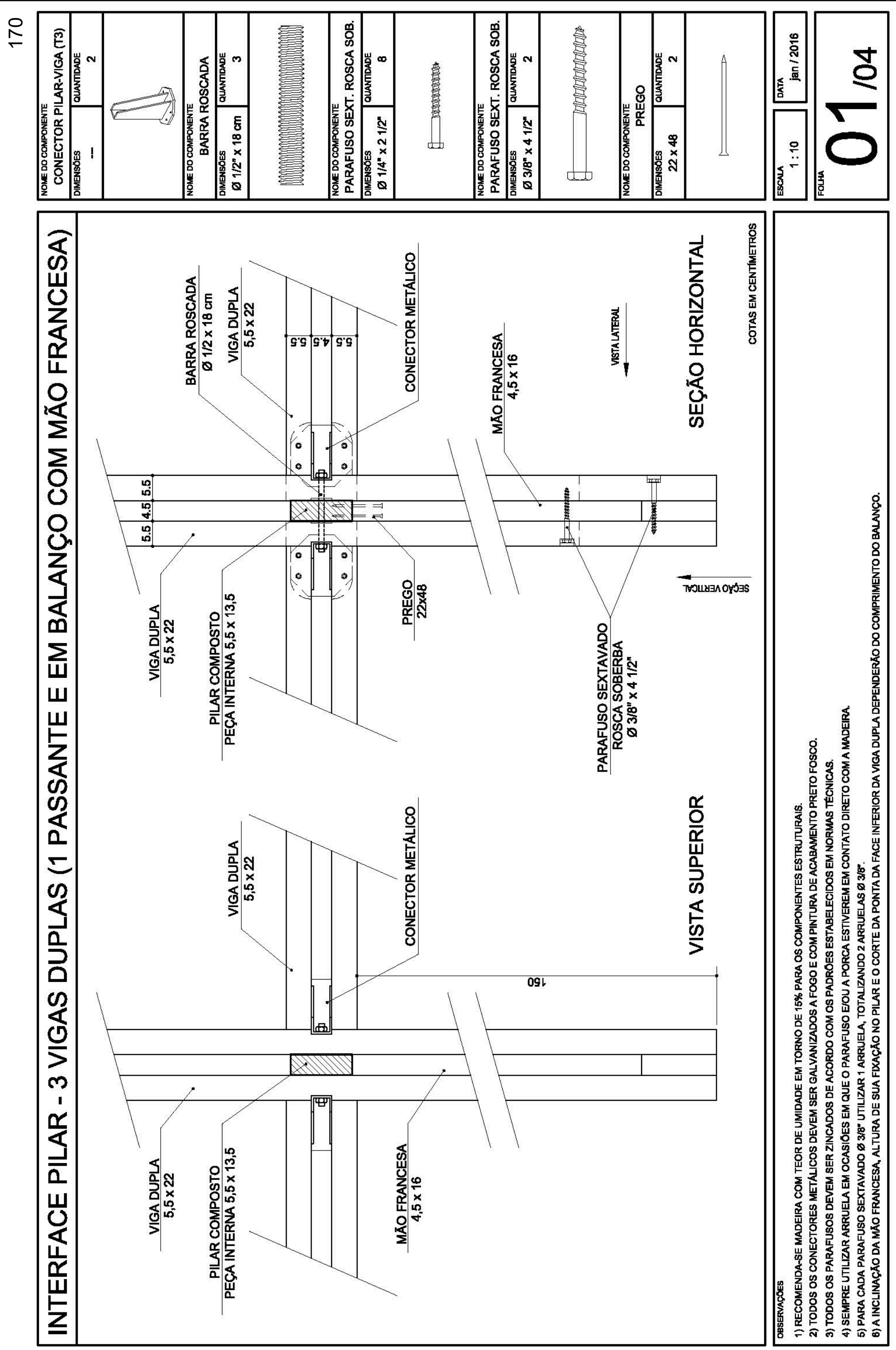

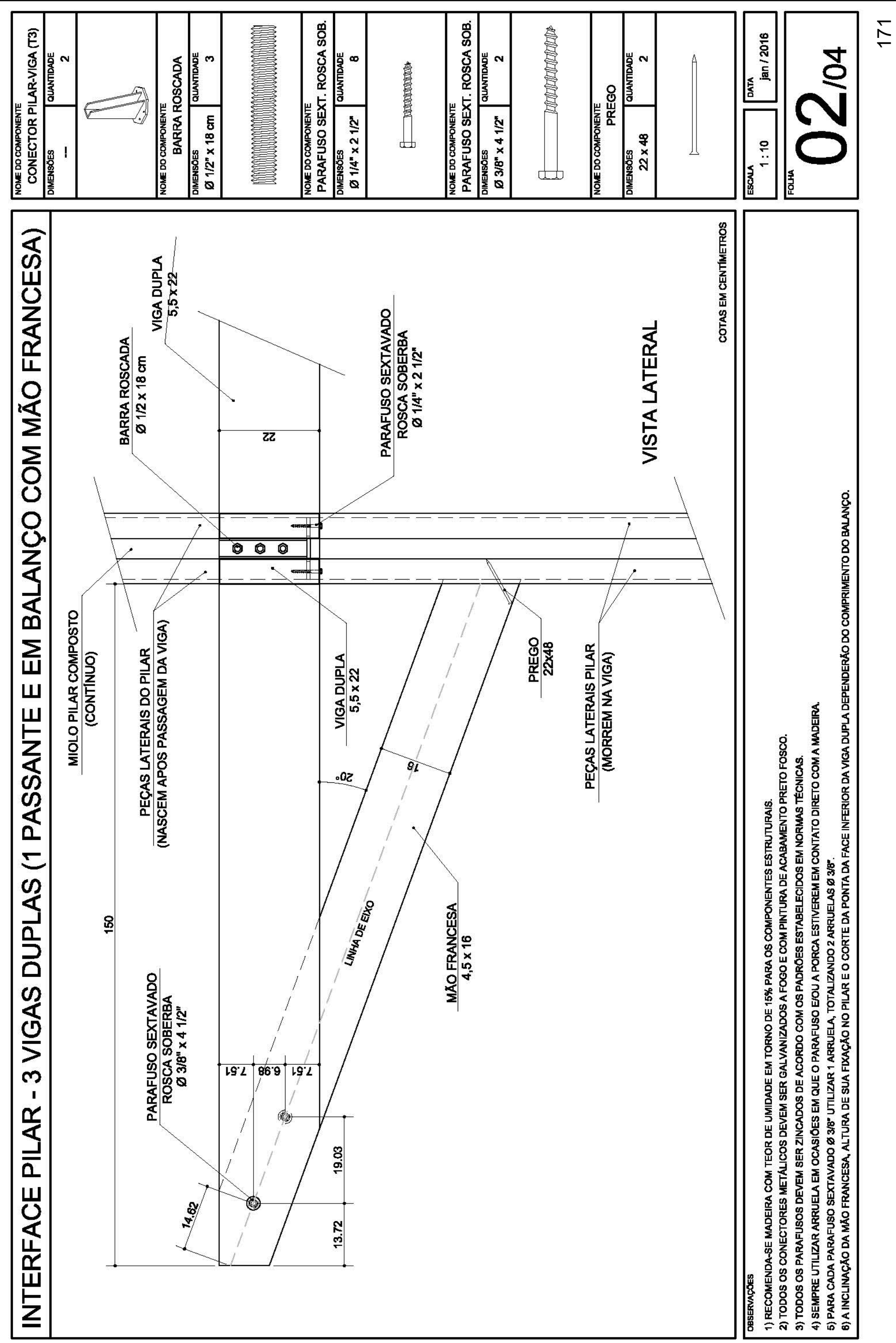

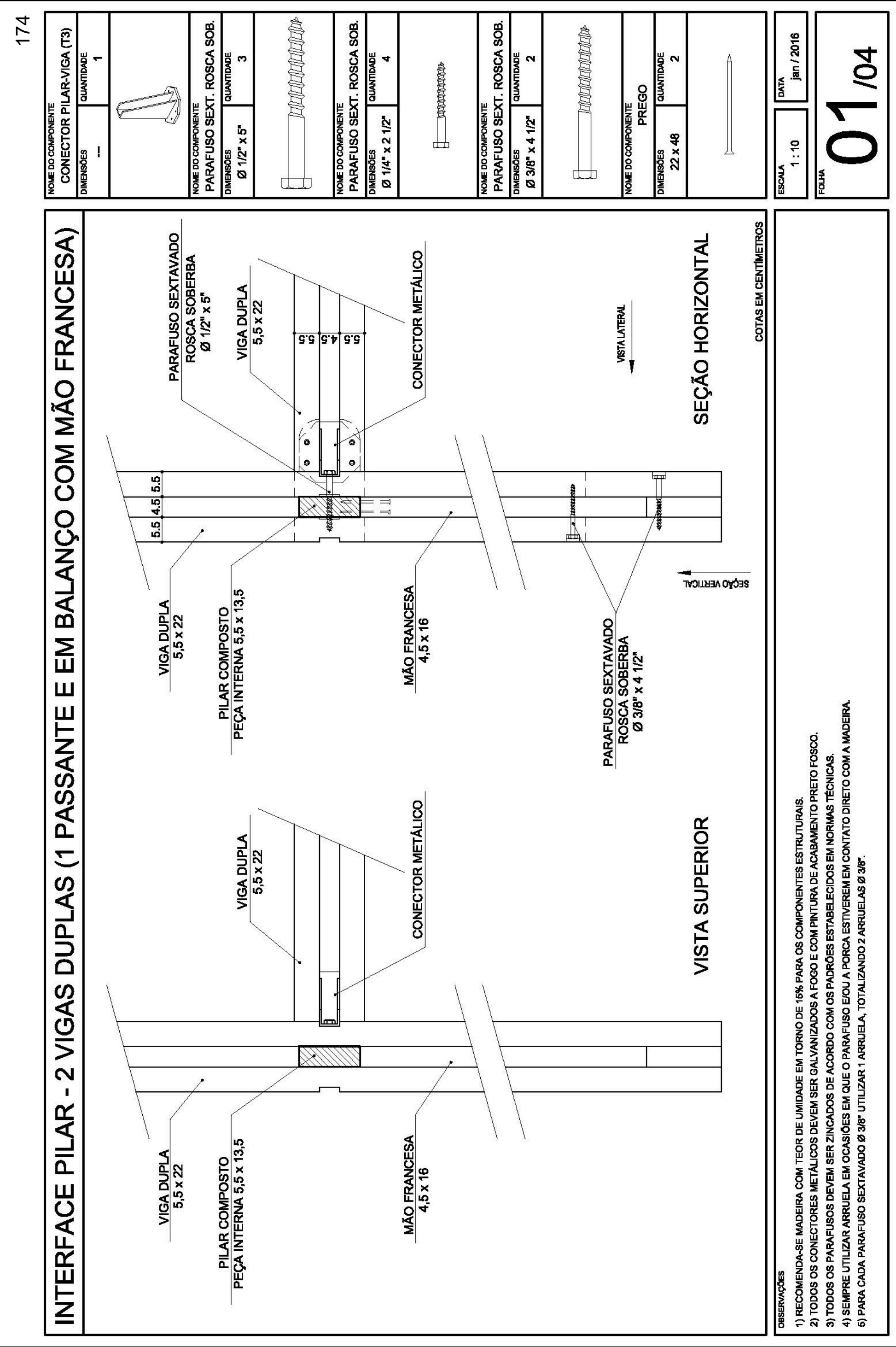

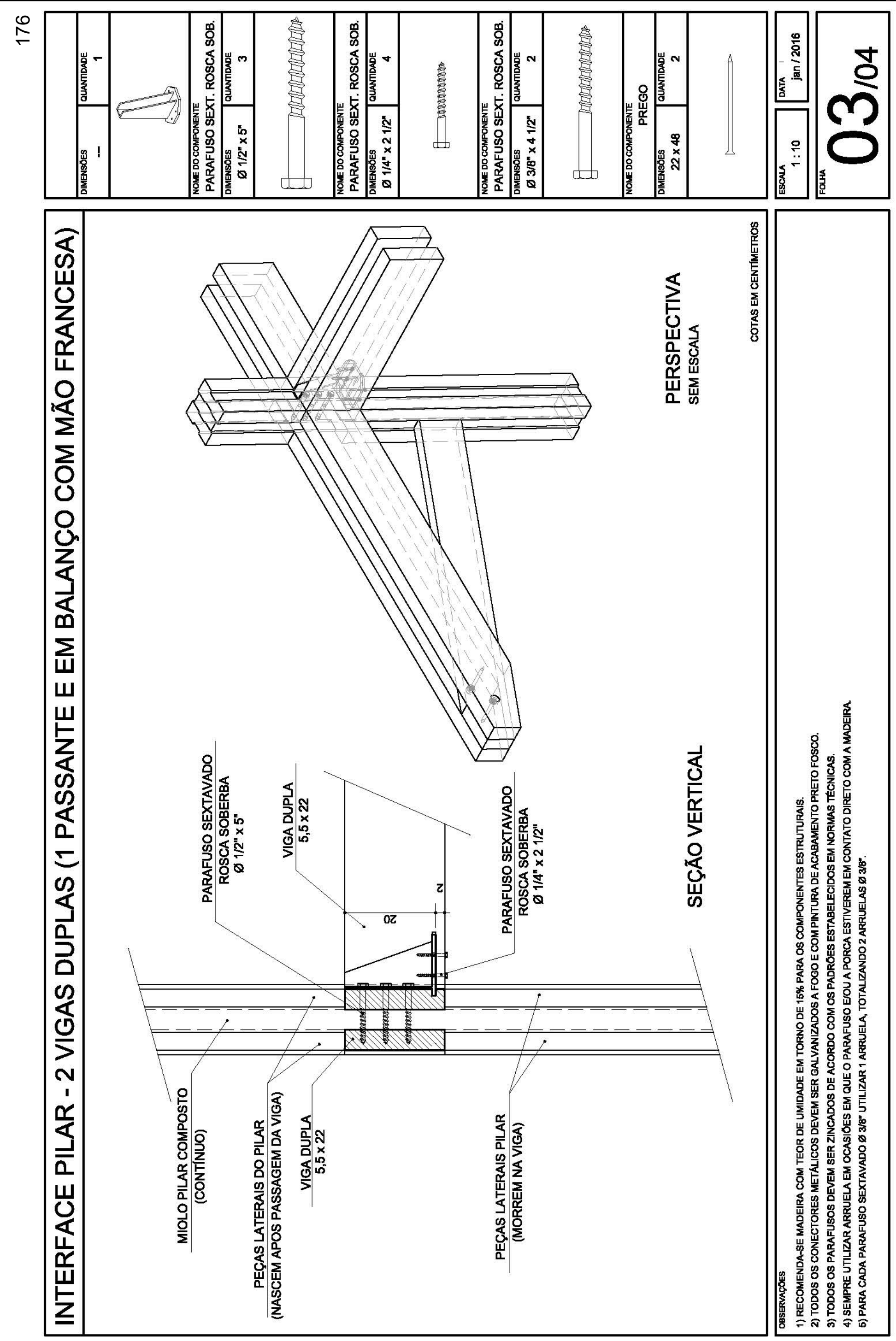


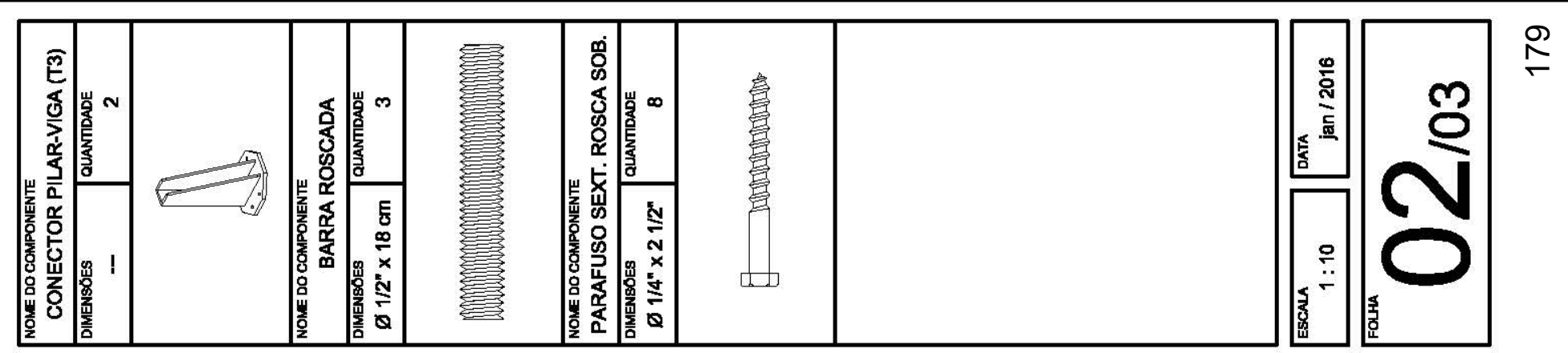

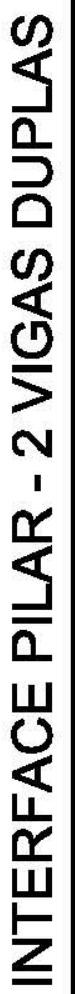
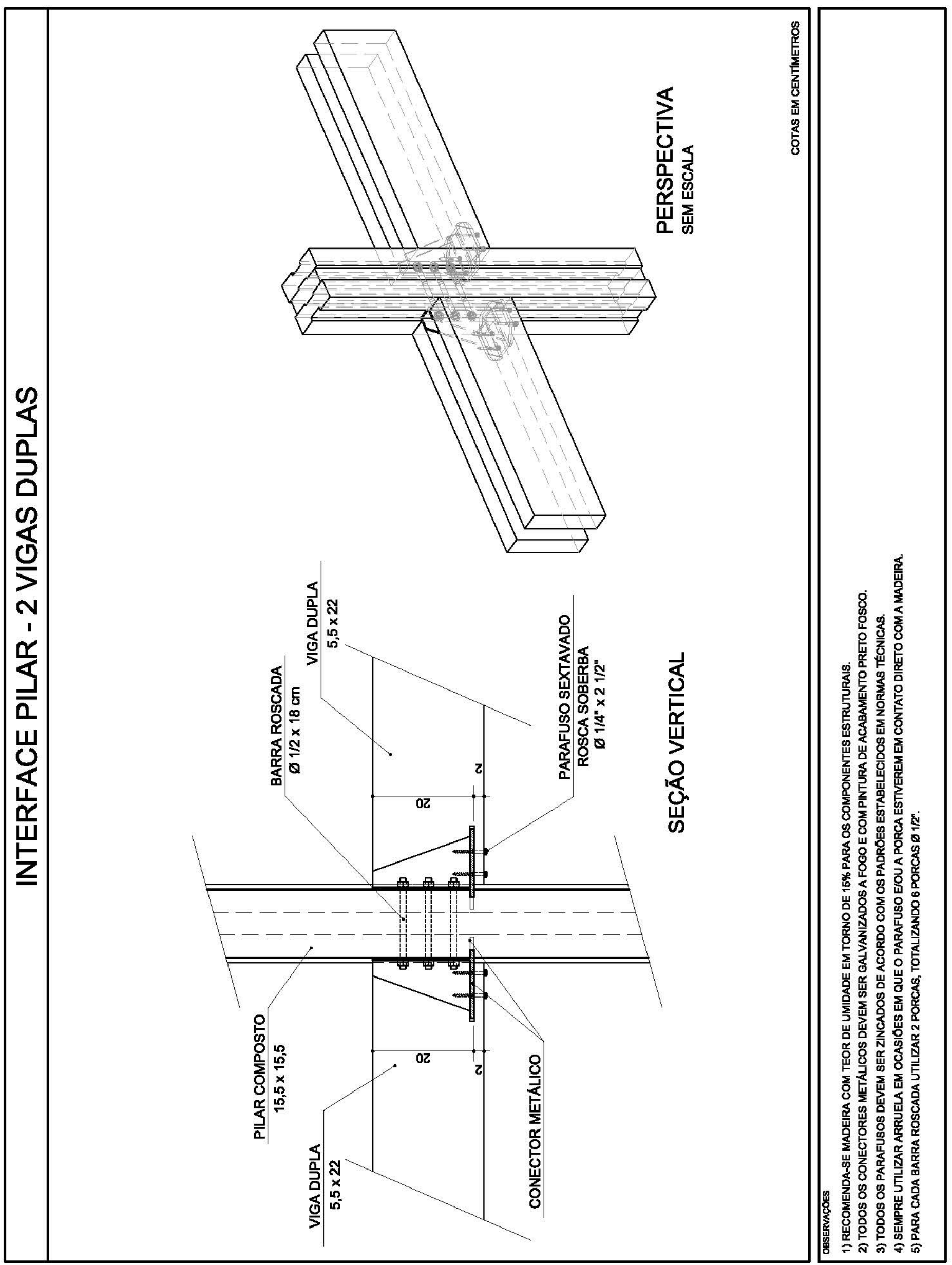

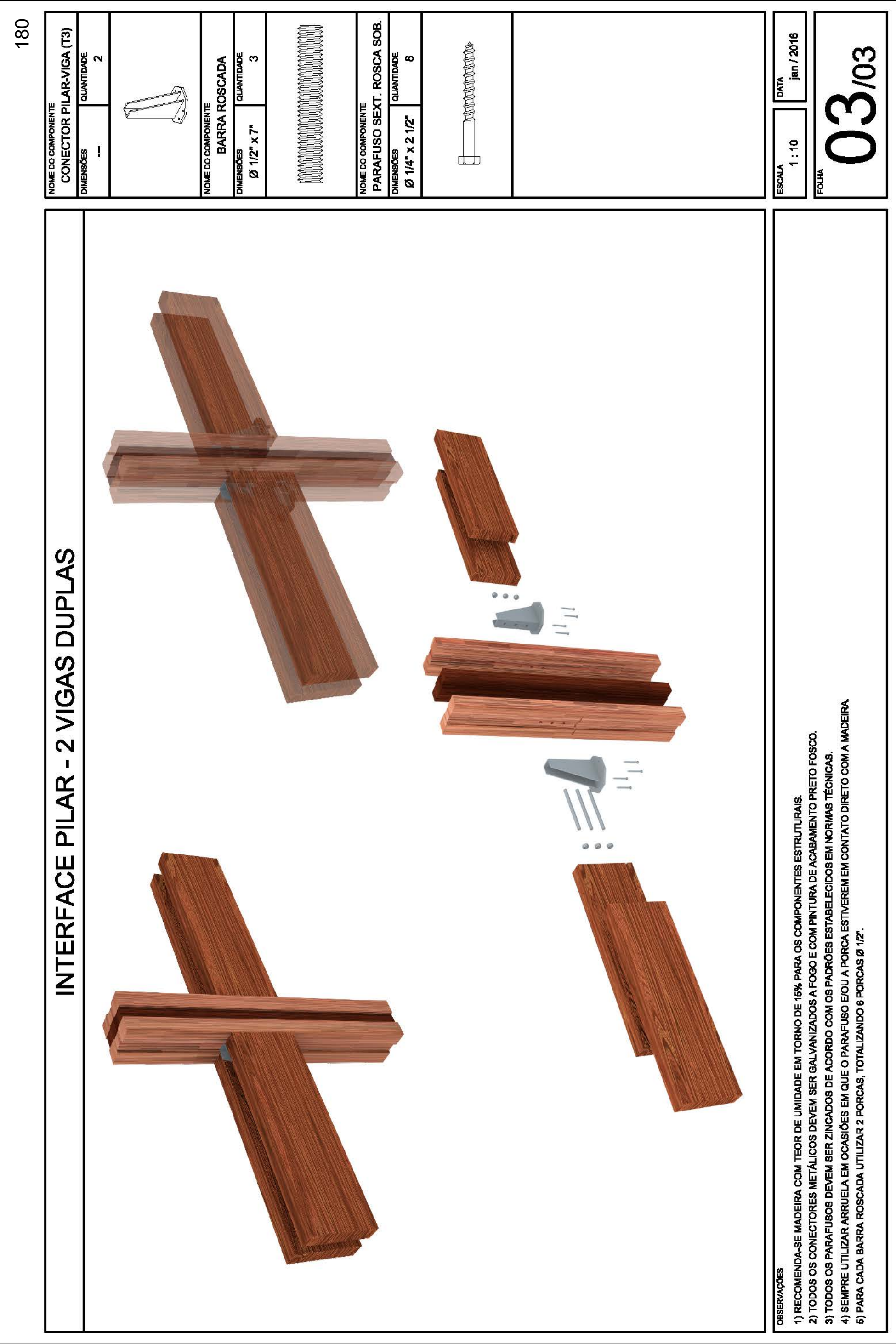

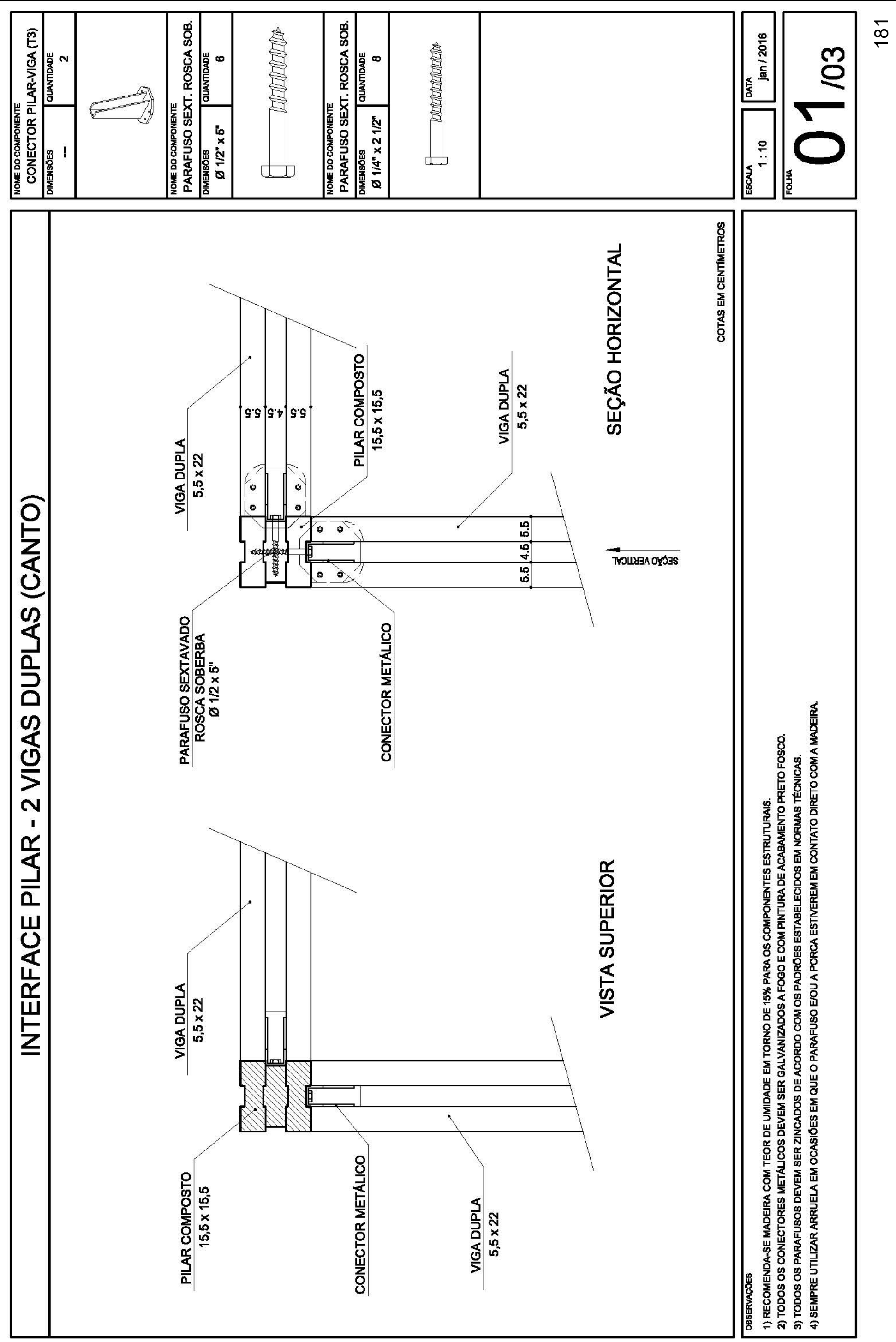

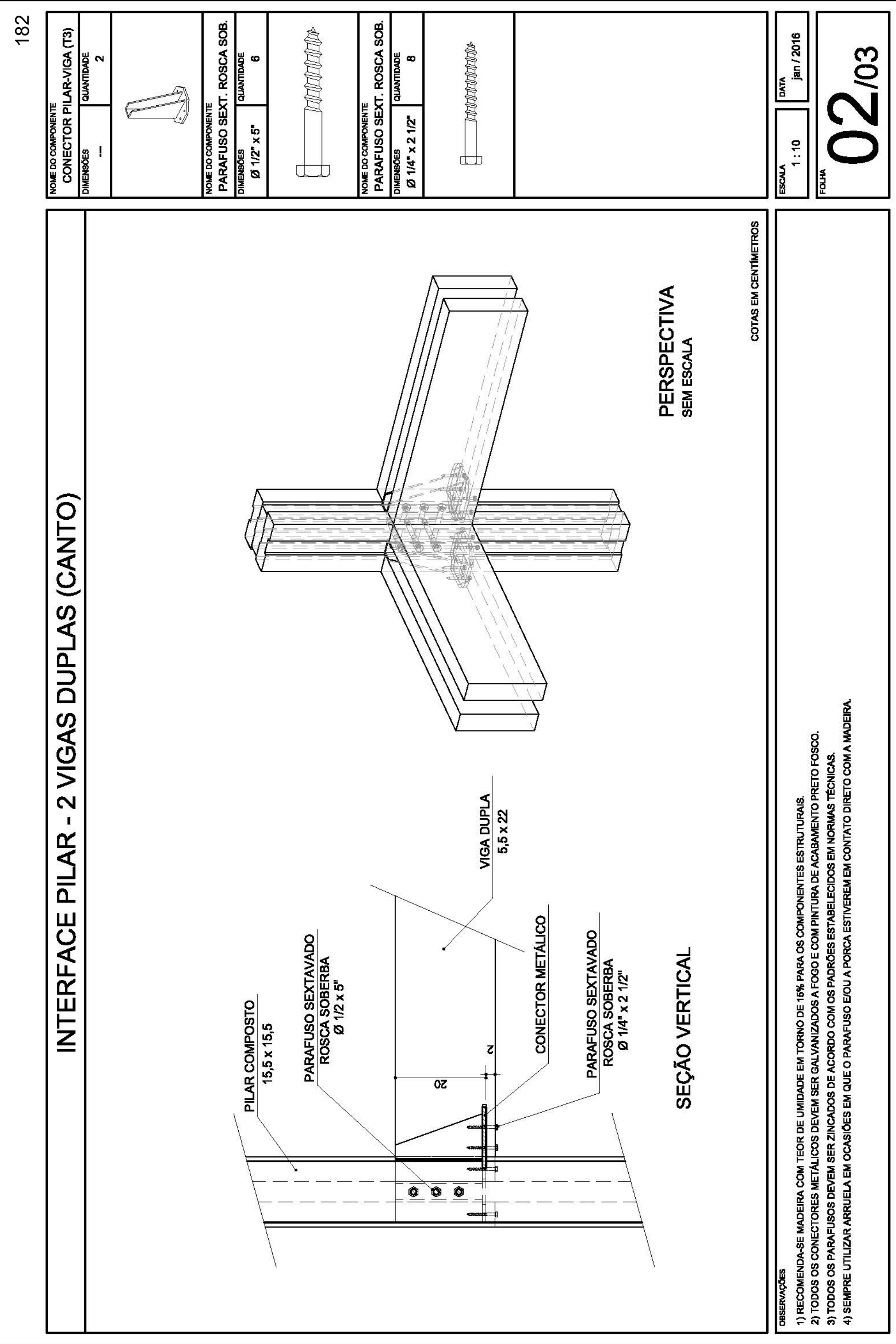


\subsubsection{Interface Viga-viga}

Nesta etapa será apresentada uma proposta para interface entre duas vigas que se encontram perpendicularmente, executada com o auxílio de um conector metálico e parafuso de rosca soberba.

Uma outra possibilidade, também apresentada, é o encontro de uma viga dupla com outras 2 vigas duplas perpendiculares à primeira, com utilização de conector metálico e barra roscada. 

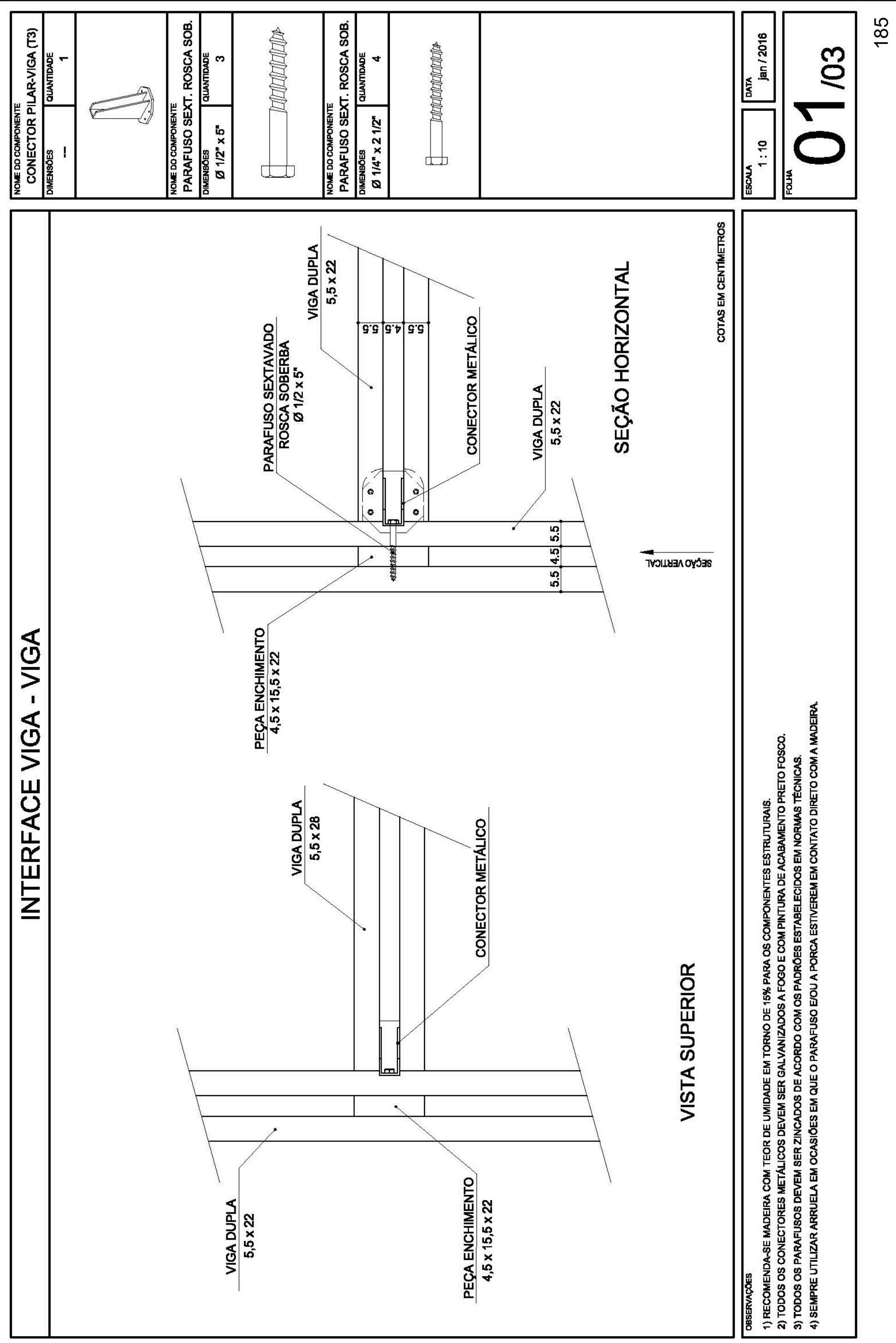

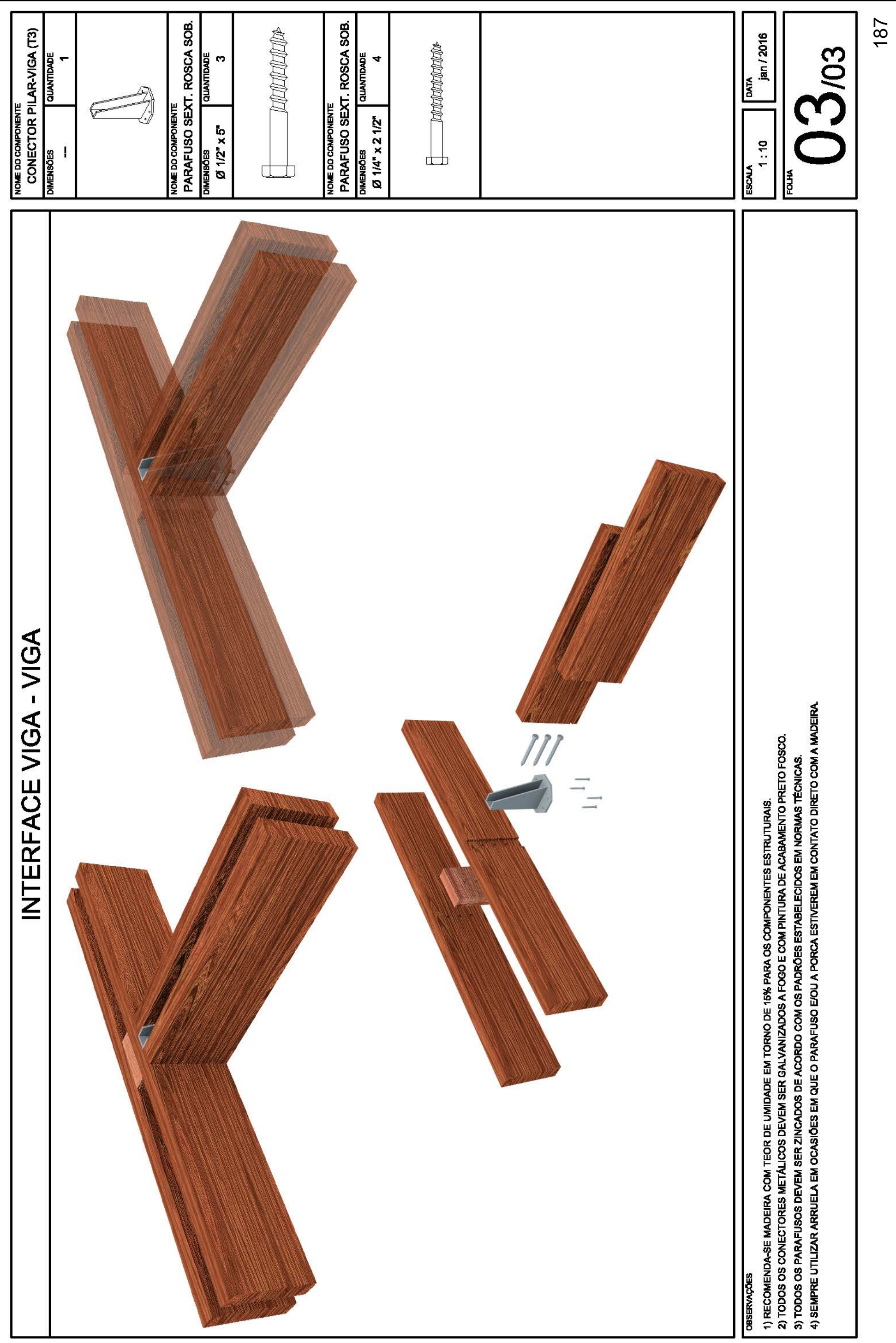


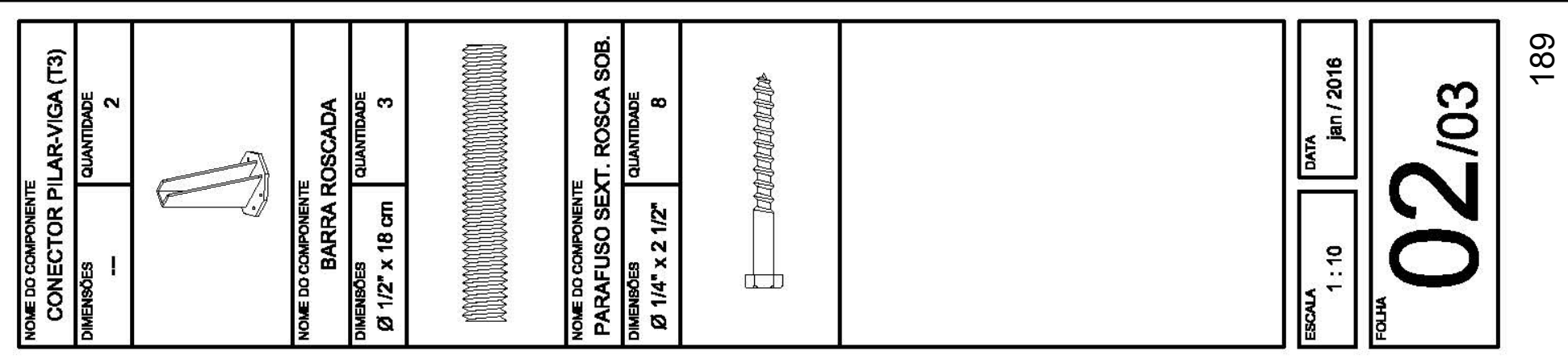

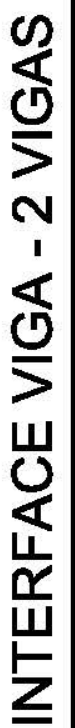

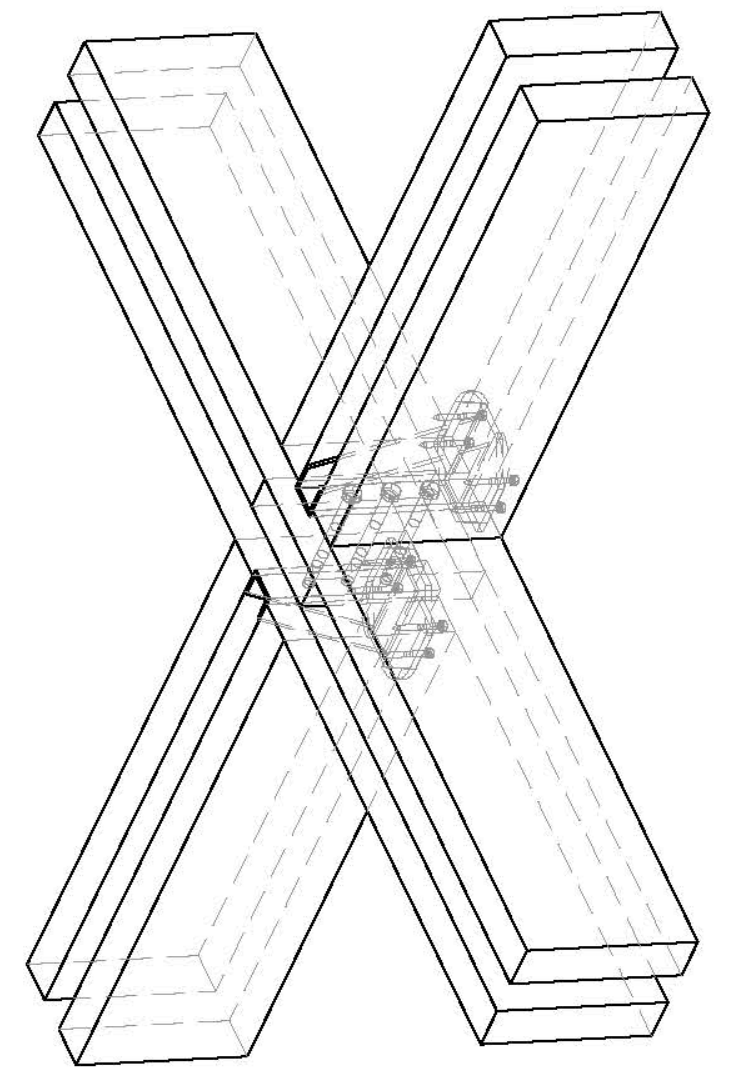

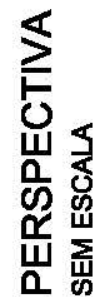
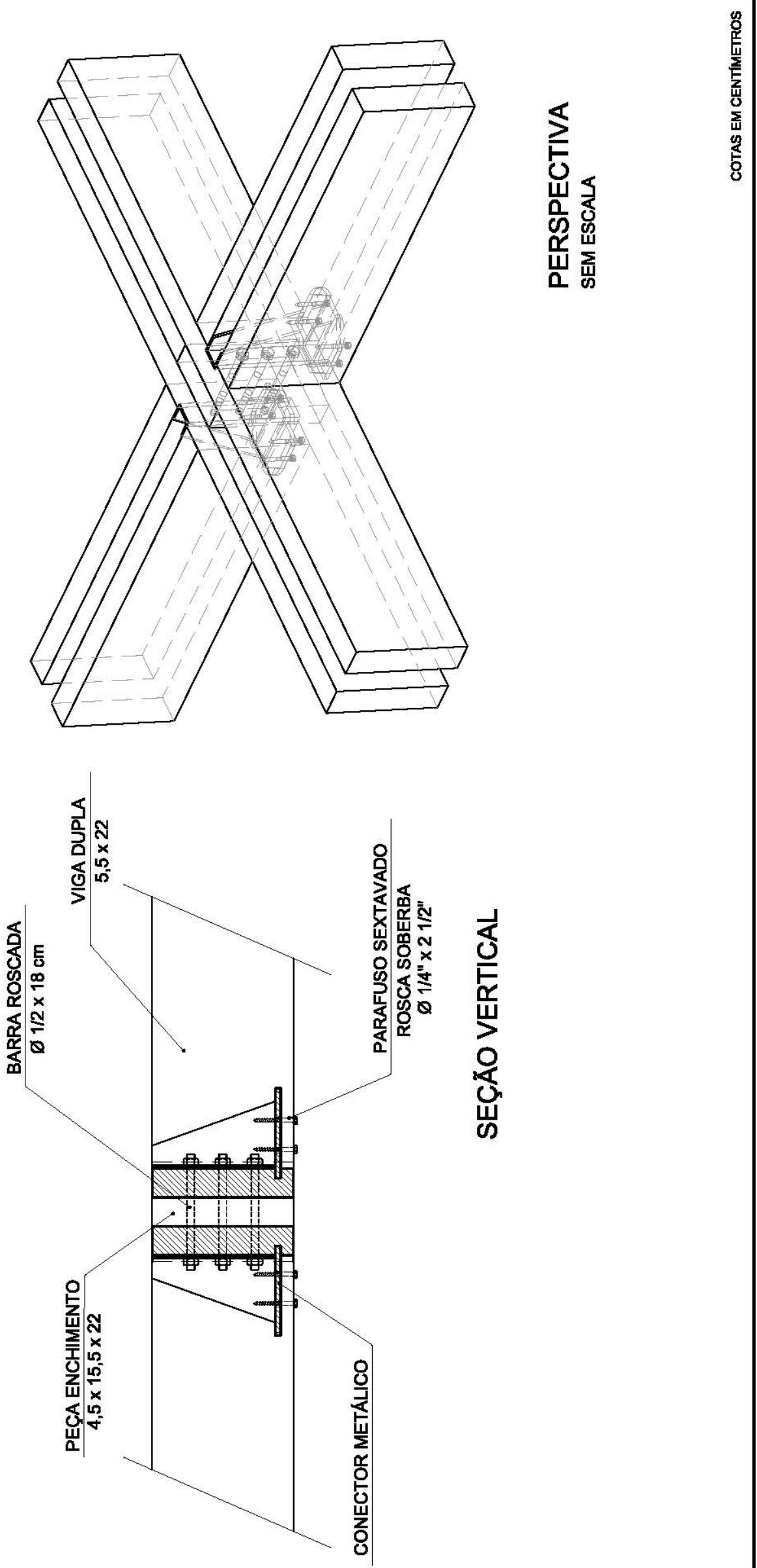

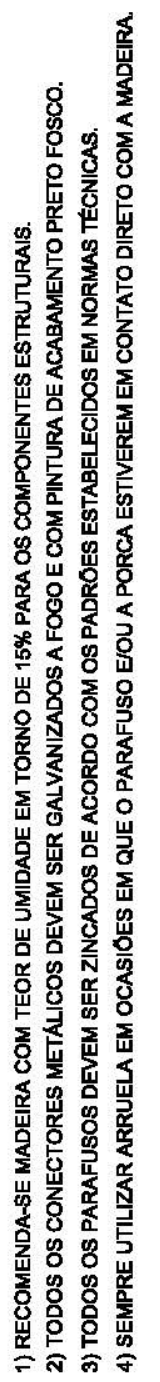



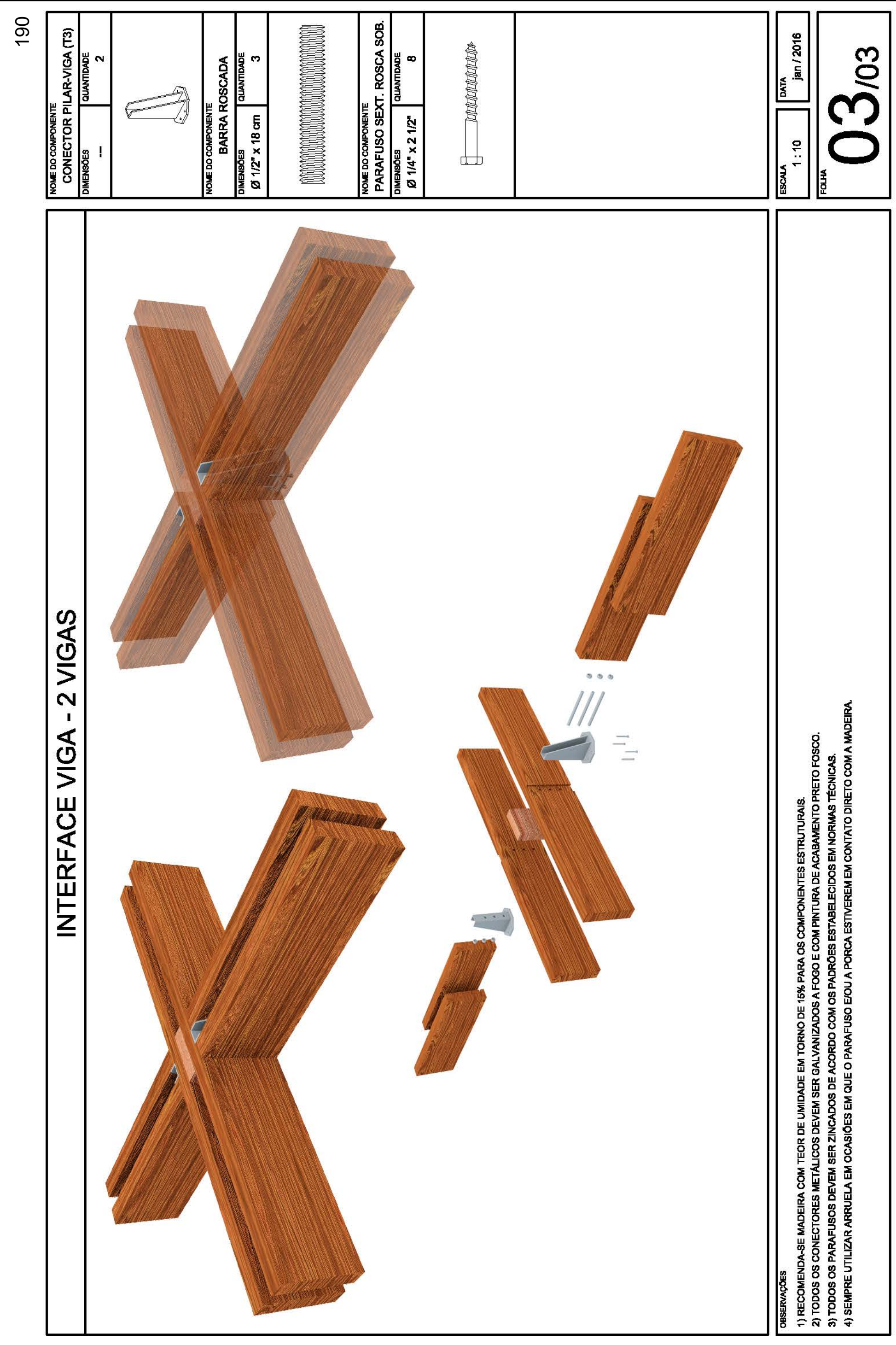


\subsubsection{Solidarização de viga}

Nesta etapa será apresentada uma proposta que possibilite a união de duas vigas de $11 \mathrm{~cm}$ de altura para a formação de uma seção de $22 \mathrm{~cm}$ (seção adotada nas propostas), através de uma peça de madeira e parafusos passantes.

De acordo com o cálculo estrutural, a peça de madeira proposta para a solidarização das vigas pode ser substituída por uma maior quantidade de parafusos, bem como pela possibilidade de inserção de uma chapa metálica nas faces superior e inferior das vigas.

Esta proposta segue o mesmo princípio do pilar composto, ou seja, uma redução na seção das peças e sua união para formação de seções maiores caso necessário, otimizando o aproveitamento do desdobro da tora e aquisição de peças com seções reduzidas. 

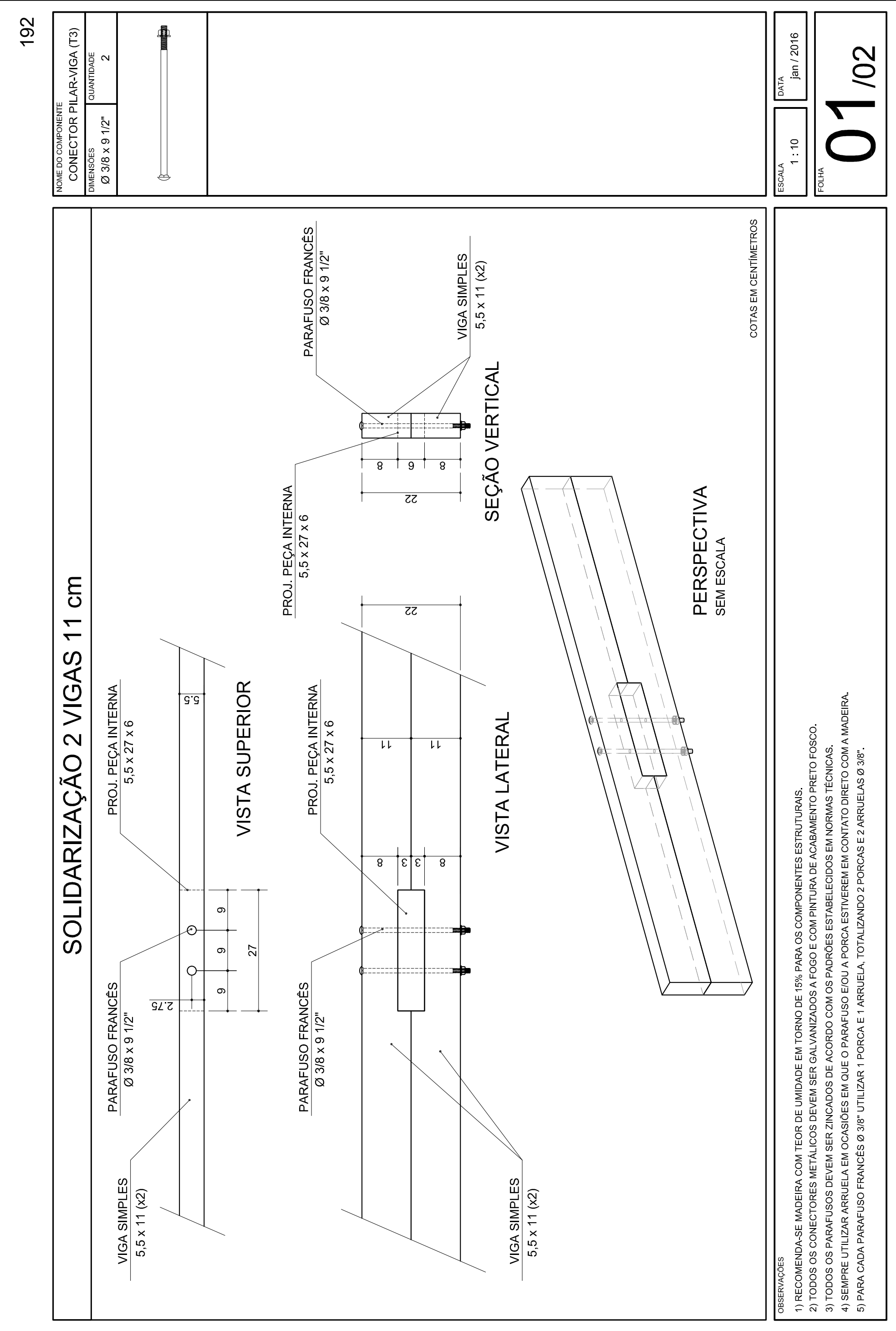

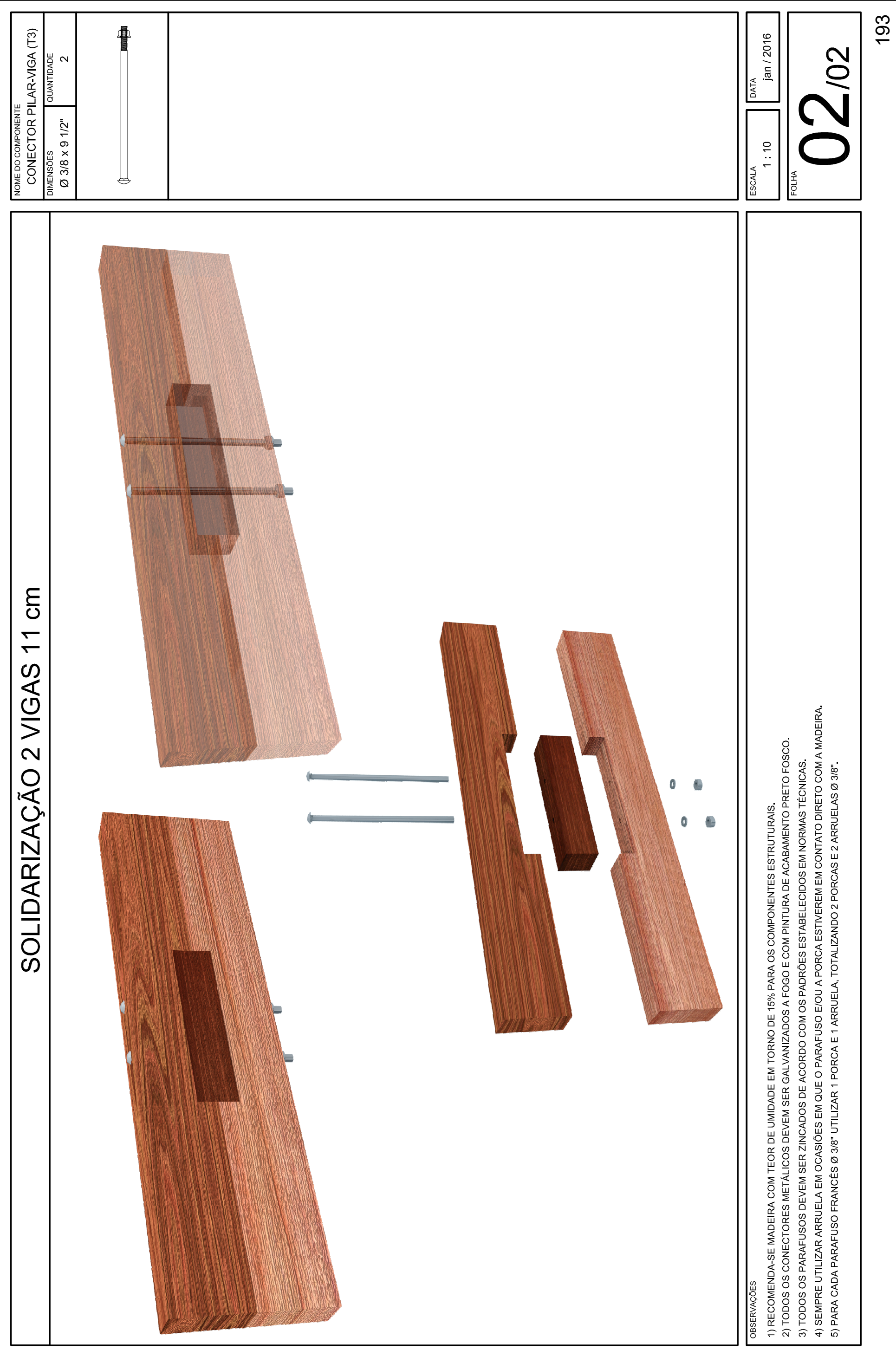


\subsubsection{Junção das vigas duplas}

Nesta etapa será apresentada uma proposta para a união das vigas duplas ao longo do seu comprimento através de peças de madeira fixada através de pregos no intuito de reduzir o comprimento de flambagem da viga dupla e consequentemente sua estabilidade lateral devido à esbeltez das peças que a compõem.

A distância entre os espaçadores deve ser definida através de cálculo estrutural, levando em consideração as especificidades de cada projeto.

Esta proposta pode ser utilizada tanto nas vigas duplas com seção única ou para aquelas solidarizadas, composta por peças com seções menores, ambas apresentadas a seguir. 

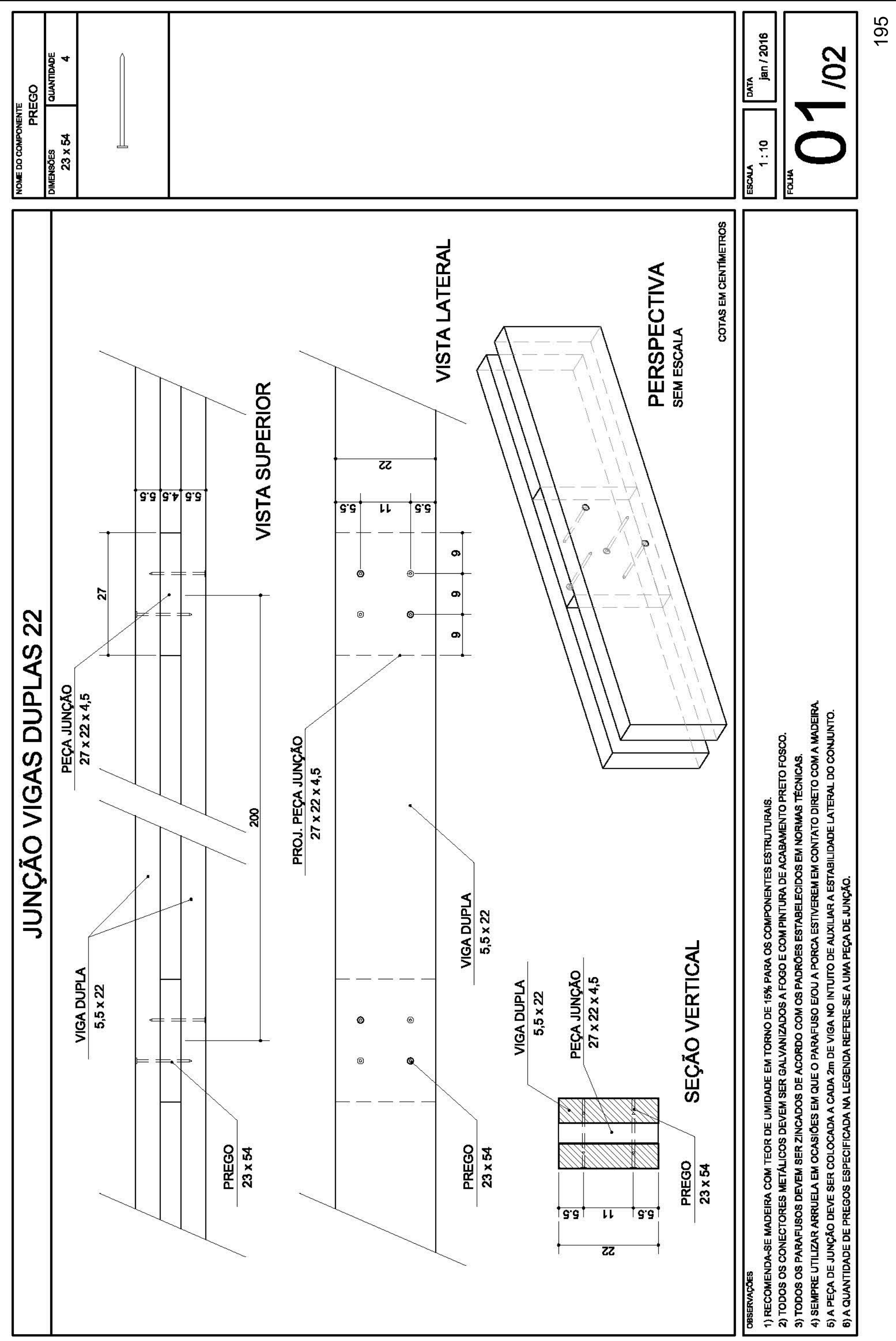

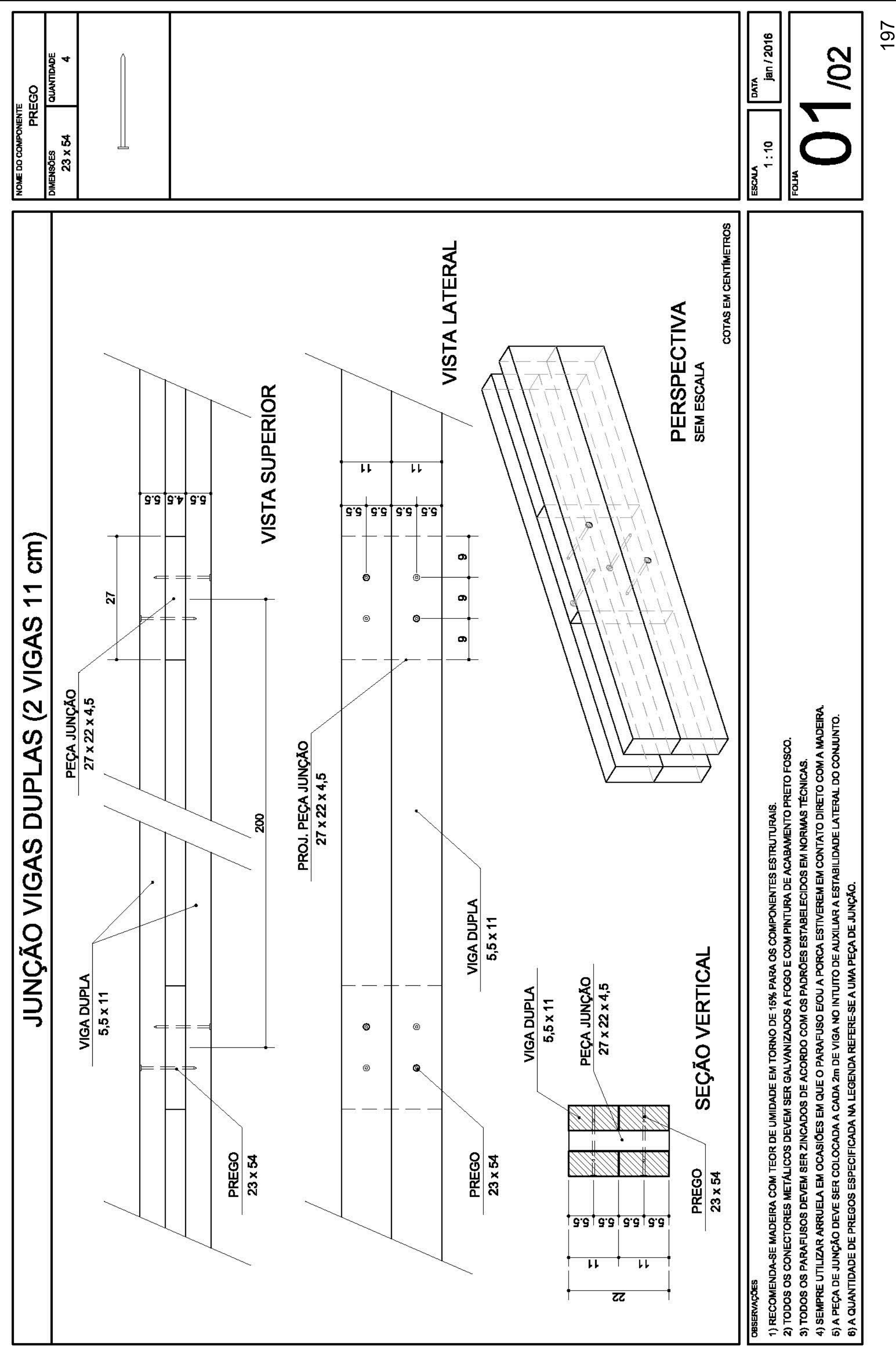


\subsection{TABELA DE VOLUME E CONSUMO ENERGÉTICO PARA A PRODUÇÃO DE COMPONENTES METÁLICOS POR INTERFACE}

$\mathrm{Na}$ Tabela 5 serão apresentados o volume de componentes metálicos utilizados por tipo de interface e uma estimativa de consumo energético para a produção, transporte e fabricação de $1 \mathrm{~m}^{3}$ de aço, levando em consideração o valor médio de $550 \mathrm{kWh}$, calculado a partir dos dados apresentados anteriormente na Tabela 3 (p. 55).

Salienta-se o baixo volume e consequentemente o baixo consumo energético para a produção de tais componentes utilizados nas interfaces propostas, quando comparados, por exemplo, a edificações dotadas de estrutura de concreto armado ou aço.

Pode-se utilizar, a título comparativo, o exemplo de uma viga de concreto armado com 4,00 $\mathrm{m}$ de comprimento e que possua uma armadura positiva de 2 $\varnothing 10 \mathrm{~mm}$ e uma armadura porta-estribo de $2 \varnothing 8 \mathrm{~mm}$, que perfaz uma área de aço de $2,57 \mathrm{~cm}^{2}$ e um volume de $1.028 \mathrm{~cm}^{3}$. Este valor por si só, já é superior ao volume de aço de todas as interfaces propostas, exceto entre pilar-fundação e pilar-4 vigas duplas.

Levando-se em consideração o fato de que a interface entre pilar-4 vigas possui justamente 4 vigas, o valor encontrado acima pode ser multiplicado por 4 , perfazendo um volume aproximado de $4.122 \mathrm{~cm}^{3}$, muito superior ao apresentado na Tabela 5 bem como a energia necessária para sua produção, transporte e fabricação. 
Tabela 5 - Volume de componentes metálicos utilizados em cada interface e estimativa de consumo energético para sua produção, transporte e fabricação

\begin{tabular}{|c|c|c|c|c|c|c|c|c|c|c|}
\hline Interface & Modelo & $\begin{array}{l}\text { Conector } \\
\text { metálico }\end{array}$ & $\begin{array}{l}\text { Barra } \\
\text { roscada }\end{array}$ & $\begin{array}{c}\text { Parafuso } \\
\text { francês }\end{array}$ & $\begin{array}{l}\text { Parafuso } \\
\text { passante }\end{array}$ & $\begin{array}{l}\text { Parafuso } \\
\text { soberbo }\end{array}$ & Arruela & Porca & $\begin{array}{c}\text { Volume } \\
\text { Total } \\
\left(\mathrm{cm}^{3}\right)\end{array}$ & \begin{tabular}{|c|} 
Energia \\
necessária para \\
produção, \\
transporte e \\
fabricação \\
(kWh) \\
\end{tabular} \\
\hline $\begin{array}{l}\text { Pilar-fundação } \\
\text { (tipo 1) }\end{array}$ & & 215,53 & & & & 27,00 & & & 242,53 & 0,13 \\
\hline $\begin{array}{l}\text { Pilar-fundação } \\
\text { (tipo 2) }\end{array}$ & & 1049,60 & 142,15 & & & & & 29,27 & 1221,02 & 0,67 \\
\hline $\begin{array}{l}\text { Pilar-4 vigas } \\
\text { duplas }\end{array}$ & & 1114,40 & 137,28 & & & 36,09 & & 29,27 & 1317,04 & 0,72 \\
\hline $\begin{array}{l}\text { Pilar-3 vigas } \\
\text { duplas }\end{array}$ & & 835,80 & 69,49 & & & 81,19 & & 14,64 & 1001,12 & 0,55 \\
\hline $\begin{array}{l}\text { Pilar-3 vigas } \\
\text { duplas ( } 1 \text { passante } \\
\text { em balanço com } \\
\text { mão francesa) }\end{array}$ & & 557,20 & 69,49 & & & 35,03 & 1,07 & $\mid 14,64$ & 677,43 & 0,37 \\
\hline $\begin{array}{l}\text { Pilar-2 vigas } \\
\text { duplas (1 passante } \\
\text { em balanço com } \\
\text { mão francesa) }\end{array}$ & & 278,60 & & & & 77,94 & 1,07 & & 357,61 & 0,20 \\
\hline $\begin{array}{c}\text { Pilar-2 vigas } \\
\text { duplas }\end{array}$ & & 557,20 & 69,49 & & & 18,04 & & 14,64 & 659,37 & 0,36 \\
\hline $\begin{array}{l}\text { Pilar-2 vigas } \\
\text { duplas (canto) }\end{array}$ & & 557,20 & & & & 126,30 & & & 683,50 & 0,38 \\
\hline Viga-viga & & 278,60 & & & & 63,15 & & & 341,75 & 0,19 \\
\hline Viga- 2 vigas & & 557,20 & & & & 18,04 & & & 575,24 & 0,32 \\
\hline $\begin{array}{l}\text { Solidarização } 2 \\
\text { vigas } 11 \mathrm{~cm}\end{array}$ & & & & 40,37 & & & 1,07 & 4,57 & 46,01 & 0,03 \\
\hline
\end{tabular}

Fonte: Elaborada pelo autor 


\section{CONCLUSÕES}

Após a realização de uma análise referente ao objetivo proposto, pode-se concluir o pleno alcance do mesmo, levando em consideração alguns aspectos referentes às suas especificidades.

No que diz respeito ao estudo das metodologias relacionadas à aplicação de conceitos de sustentabilidade na arquitetura e no projeto de componentes estruturais, verificou-se que, hoje, as alterações climáticas iniciadas no século $\mathrm{XX}$ tornam-se cada vez mais evidentes e representam um dos maiores desafios ambientais do século $X X I$, sendo que a degradação do meio ambiente está diretamente ligada às atividades humanas, que têm participação fundamental em tais alterações, devido à queima de combustíveis fosseis, carvão, gás e produção de cimento, principalmente após a Revolução Industrial, promovendo um aumento dos níveis de emissão de gases do efeito estufa e $\mathrm{CO}_{2}$ na atmosfera, contribuindo para um aumento da temperatura do planeta.

A construção civil é um segmento que tem muito a contribuir com o caráter sustentável na obtenção, gestão e utilização dos materiais, principalmente na busca de alternativas para o desperdício praticado nos canteiros de obras dos sistemas tradicionais de construção, que têm como características principais a lentidão no processo construtivo, desperdício de materiais e consequentemente a geração de resíduos, sendo que o descarte ao final da vida útil é um dos impactos mais preocupantes na análise da cadeia produtiva de um produto. $O$ combate ao desperdício se dá ainda durante o processo produtivo, pela adoção de tecnologias menos intensivas em energia e que requeiram menos matérias-primas.

Nesse sentido conclui-se que a arquitetura tem papel fundamental para a redução da degradação ambiental, sendo que a denominação de arquitetura sustentável está intimamente ligada àquela que respeita a natureza dos materiais, extraindo deles seu melhor comportamento, contribuindo diretamente para um melhor desempenho das edificações. Tal arquitetura propõe o uso da simplicidade, com baixo custo energético para a obtenção de resultados práticos, pautada em fundamentos teórico-científicos, tornando os projetos mais abrangentes. 
A análise e caracterização dos produtos de base florestal visando possíveis aplicações no projeto de componentes estruturais apontou para o fato de que os produtos de base florestal podem contribuir não apenas para a manutenção ou aumento de estoques de carbono nas áreas de plantio, mas também para evitar as potenciais emissões associadas ao uso de produtos oriundos de matérias-primas fósseis ou não renováveis em diferentes etapas da cadeia produtiva, o que traz inúmeros benefícios às atuais condições climáticas, buscando o alcance do desenvolvimento sustentado não só pela produção direta de madeira e de matériaprima na fabricação de produtos dela derivadas, mas pela geração de outros bens, sempre primando pela manutenção do equilíbrio ecológico.

Verificou-se que no Brasil há uma situação florestal favorável no que se refere à alta capacidade de produção de madeira proveniente de atividades silviculturais e de manejo florestal certificado. O elevado potencial de emprego da madeira como material de construção, somado ao conhecimento técnico e científico e à qualificação dos profissionais do setor da construção civil e da cadeia produtiva da madeira, pode favorecer o desenvolvimento e a produção de forma sustentável de edificações em madeira, em particular de componentes estruturais pré-fabricados.

Conclui-se portanto que a cadeia produtiva do setor brasileiro de florestas plantadas caracteriza-se pela sua grande diversidade, fato que possui uma parcela de contribuição importante na geração de produtos, tributos, empregos e bem-estar, tanto para segmentos industriais, na fabricação de celulose e papel, painéis de madeira industrializada, processamento mecânico, madeira tratada, siderurgia a carvão vegetal e geração de energia, destinados principalmente à construção civil quanto para produtos não madeireiros como óleos, corantes, resinas, borracha natural, destinados à indústria química, farmacêutica e ramo alimentício. Além das funções e aplicações descritas acima, a produção florestal possui uma importante função ambiental, contribuindo para a conservação e preservação dos recursos naturais, destacando-se a regulação do solo, qualidade do ar e do clima, fixação de carbono, além de possuir valor estético, artístico e científico.

Em relação aos estudos para a elaboração de projeto executivo e modelagem virtual de componentes estruturais que incorporem conceitos de sustentabilidade, no intuito de reduzir desperdícios e geração de resíduos nos processos de préfabricação e montagem, os mesmos apontaram para o fato de que, sistemas 
construtivos em madeira possuem um processo produtivo que pode ser classificado como um sistema construtivo racionalizado, visto que as atividades em canteiro de obra são exclusivamente de encaixe e montagem dos componentes, o que diminui o tempo de obra, evita desperdícios e consequentemente a geração de resíduos.

Portanto, os sistemas construtivos que se utilizam da madeira para fins estruturais contam com uma sensível agilidade no cronograma, diminuindo o tempo gasto na execução da obra, garantindo a redução de custos diretos e indiretos, bem como a valorização estética da obra, visto que os sistemas construtivos convencionais, especificamente aqueles que adotam componentes estruturais em concreto armado, pressupõem etapas de preparação de formas, armações, escoramentos e concretagens, além do tempo de espera de cura e desforma do concreto.

Uma consideração importante é que o sistema construtivo estrutural apresentado neste trabalho dispensa a necessidade de uma mão-de-obra com elevado nível de especialização, devido a uma praticidade do processo de montagem, uma vez que, na maioria das vezes, as peças estruturais podem ser colocadas na obra devidamente numeradas e com os conectores metálicos fixados nas peças de madeira, propiciando uma agilidade ainda maior no processo de montagem em canteiro de obra.

Outro fator importante e que merece destaque é o fato de que as interfaces podem sofrer uma melhoria e otimização à medida que forem colocadas em prática, verificadas as dificuldades de manuseio, trabalhabilidade e execução das conexões propostas.

Além do detalhamento dos projetos do produto e da produção, deve-se considerar a logística de transporte da madeira bruta, da madeira aparelhada e dos componentes pré-fabricados, as diretrizes e orientações da mão de obra nas bancadas de produção, o projeto dos gabaritos e a forma de estocagem nas unidades de produção e no canteiro de obra. Cabe destacar também a necessidade de planejamento das etapas de montagem em canteiro de obra, o detalhamento executivo das interfaces e ligações, o gerenciamento dos agentes envolvidos no empreendimento e o acompanhamento sistemático das etapas de execução.

Pode ser apontado também o fato de que uma alternativa viável para uma maior inserção da madeira como componente estrutural no mercado imobiliário 
brasileiro seria a utilização de sistemas construtivos mistos madeira-alvenaria, pois 0 fechamento em alvenaria é largamente difundido, além de apresentar custo reduzido e não exigir mão de obra com elevada qualificação e especialização.

Levando-se em consideração todos os aspectos levantados e analisados ao longo da pesquisa, pode-se concluir que a alteração de um processo de construção tradicional executada em canteiro de obra para uma construção racionalizada desenvolvida para montagem, com um processo de pré-fabricação bem planejado, torna a cadeia produtiva da habitação mais eficiente, com redução de tempo de construção e aprimoramento da qualidade dos subsistemas e da edificação com o todo.

Outra conclusão é o fato de que o êxito na construção de sistemas construtivos com madeira está relacionado diretamente a um conjunto de fatores, sendo os principais:

a) apurado desenvolvimento do projeto executivo de produção de componentes;

b) controle da qualidade na etapa de produção dos componentes em unidades de pré-fabricação;

c) gerenciamento e controle das etapas de montagem em canteiro de obra;

d) especificação detalhada dos conectores e componentes de ligação e fixação com vista à correta execução das interfaces dos componentes estruturais.

Por fim, conclui-se que a utilização da pré-fabricação de componentes para sistemas construtivos estruturais em madeira representa uma alternativa extremamente viável dentro da realidade da construção civil brasileira, considerando um contexto no qual se reúna apurado desenvolvimento do projeto executivo e elevados graus de gerenciamento e planejamento das etapas de produção e execução em canteiro. 


\subsection{RECOMENDAÇÕES FUTURAS}

- Realização de um cálculo de uma distância limite média em que seja viável a utilização de madeira nativa proveniente de área de manejo certificado, no que diz respeito às emissões de carbono e energia incorporada, comparadas principalmente aos processos de secagem e tratamento preservativo da madeira de florestas plantadas.

- Realização de ensaios em laboratório para a caracterização mecânica e comportamento estrutural das interfaces propostas, com a finalidade de se obter valores de referência para diversas seções de vigas e pilares.

- Elaboração de uma tabela geral para cálculo do consumo energético dos materiais vinculada a uma proposta de sistema construtivo que utilize a madeira (tanto de floresta nativa quanto plantada), levando em consideração a os componentes metálicos, no intuito de demostrar a viabilidade energética do uso da madeira.

- Elaboração de um sistema construtivo que contemple, além das interfaces apresentadas, os subsistemas de cobertura e fechamento utilizando madeira de florestas plantadas.

- Elaboração de um manual técnico de montagem de componentes e interfaces estruturais, tanto as apresentadas no presente trabalho quanto dos subsistemas de cobertura e fechamento citados no item anterior, no intuito de divulgar a possibilidade de uso da madeira de florestas plantadas para o uso proposto no trabalho. 
NBR 14806: Madeira serrada de Eucalipto - Requisitos. Rio de Janeiro, 2002. 11p.

NBR 15113: Resíduos sólidos da construção civil e resíduos inertes - Aterros Diretrizes para projeto, implantação e operação. Rio de Janeiro, 2004.

NBR 15873: Coordenação Modular em Edificações. São Paulo, 2010.

ABNT - Associação Brasileira de Normas Técnicas. NBR 7190: Projetos de Estruturas de Madeira. Rio de Janeiro, 1997. 107 p.

ADEODATO, S., VILELA, M., BETIOL, L. S., MONZONI, M., Madeira de ponta a ponta: o caminho desde a floresta até o consumo, 1ª ed. São Paulo: FGV RAE, 2011.

ADAM, R. S. Princípios do Ecoedifício: Interação entre Ecologia, Consciência e Edifício. 1.ed. São Paulo: Aquariana, 2001.

AGOPYAN, V., JOHN, V. M. O desafio da sustentabilidade na construção civil. Série Sustentabilidade, v.5. José Goldemberg (Coord.). São Paulo: Blucher, 2011. ISBN 978-85212-0610-1.

AMERICAN WOOD COUNCIL. Details for Conventional Wood Frame Construction. American Forest \& Paper Association, 2001. 52 p. Disponível em:

<http://www.awc.org/pdf/codes-standards/publications/wcd/AWC-WCD1-

ConventionalWoodFrame-ViewOnly-0107.pdf>. Acesso em: 14 abr. 2015.

ARAÚJO, H. J. B.; MAGALHÃES, W. L. E.; OLIVEIRA, L. C. Durabilidade de madeira de Eucalipto Citriodora (Corymbia citriodora (Hook.) K.D. Hill \& L.A.S.Johnson) tratada com CCA em ambiente amazônico. Acta Amazônica, vol. 42(1), p. 49-58, 2012. Disponível em: $<$ http://www.montana.com.br/International/Communication/Informacion-tecnica/Durabilidadde-la-madera-de-eucalipto-citriodora-tratada-con-CCA-en-ambiente-amazonico>.

Acesso em: 17 Jul. 2015.

ASSOCIAÇÃO BRASILEIRA DE DESENVOLVIMENTO INDUSTRIAL (ABDI). Relatório de Avaliação dos Esforços para Implantação da Coordenação Modular no Brasil, 2009. Disponível em:

<http://www.abdi.com.br/Estudo/Rel.\%20Implant.\%20da\%20Coord.\%20Modular\%20no\%20 Brasi_2l.pdf>. Acesso em: 30 Ago. 2015.

\footnotetext{
51 De acordo com a Associação Brasileira de Normas Técnicas. NBR 6023.
} 
ASSOCIAÇÃO GAÚCHA DE EMPRESAS FLORESTAIS (AGEFLOR). A indústria de base florestal no RS - Dados e fatos. Ano base 2014. Anuário 2015, Porto Alegre, RS, 2015.

ASSOCIAÇÃO BRASILEIRA DE PRODUTORES DE FLORESTAS PLANTADAS (ABRAF). Anuário Estatístico ABRAF 2013 - ano base 2012. Brasília. 2013. Disponível em <www.abraflor.org.br/estatisticas.asp>. Acesso em: 14 Abr. 2015.

BARATA, T. Q. F.; GANDINI, J. M. D. Sistema Construtivo Pré-fabricado para a Sede do Imaflora. - Piracicaba, SP. Madeira, Rio de Janeiro, v. 19, p. 1, 2006.

BARATA, T. Q. F.; GANDINI, J. M. D. Sistema Construtivo em Madeira Certificada para a Ampliação da Sede do IMAFLORA - Piracicaba, SP. In: ENCONTRO BRASILEIRO EM MADEIRA E EM ESTRUTURAS DE MADEIRA, 10, 2008, Londrina. Anais... Londrina> IBRAMEM, 2008.

BARATA, T. Q. F.; GANDINI, J. M. D. Projeto Arquitetônico e Estrutural em Madeira para Unidade Habitacional. In: CIMAD 11 - CONGRESSO IBERO-LATINOAMERICANO DA MADEIRA NA CONSTRUÇÃO, 1, 2011, Coimbra, Portugal. Anais...Coimbra: 2011

BARATA, T. Q. F.; GANDINI, J. M. D. Projeto de Produção de Componentes e Processo de Montagem de Sistemas Construtivos Pré-Fabricados com Emprego de Madeira Certificada. In: ENCONTRO BRASILEIRO EM MADEIRA E EM ESTRUTURAS DE MADEIRA, 12, 2012, Vitória. Anais... Vitória: IBRAMEM, 2012.

BARROS, A.C.; VERÍSSIMO, A. (Ed.). A Expansão madeireira na Amazônia: Impactos e perspectivas para o desenvolvimento sustentável no Pará. Belém: Imazon, 2002.

BARROS, A. D. M.; FABRícIO, M. M. Certificação Ambiental de edifícios LEED e Processo AQUA: micro, pequenas e médias empresas (MPMEs). In: ENCONTRO LATINOAMERICANO DE EDIFICAÇÕES E COMUNIDADES SUSTENTÁVEIS, 9, 2011, Vitória. Anais... Vitória, 2011.

BITTENCOURT, R. M. Concepção arquitetônica da habitação em madeira. 1995. Tese (Doutorado) - Escola Politécnica da Universidade de São Paulo, São Paulo, 1995(a).

BITTENCOURT, R. M. Aprendendo a projetar a edificação de madeira: $1^{\text {a }}$ parte (Um novo produto da prática arquitetônica). In: ENCONTRO BRASILEIRO DE MADEIRAS E EM ESTRUTURAS DE MADEIRA, 1995, Belo Horizonte. Anais... Belo Horizonte: IBRAMEM, 1995(b). p. 171-180.

BODEN, T., MARLAND, G., ANDRES, B. Global $\mathrm{CO}_{2}$ Emissions from Fossil-Fuel Burning, Cement Manufacture, and Gas Flaring: 1751-2009. Carbon Dioxide Information Analysis Center, Oak Ridge National Laboratory, 2012. Disponível em:

<http://cdiac.ornl.gov/ftp/ndp030/global.1751_2009.ems>. Acesso em 28 Mar. 2016. 
BOFF, L., Sustentabilidade: o que é - o que não é. Petrópolis: Editora Vozes, 2012. BONSIEPE, G. Teoría y Prática Del Diseño Industrial: Elementos para uma Manualística Crítica. Barcelona: Editora Gustavo Gili, 1978.

BÖRJESSON, P., GUSTAVSSON, L. Greenhouse gas balances in building construction: wood versus concrete from life-cycle and forest land-use perspectives. Energy Policy, vol. 28, n. 9, p. 575-588, jul. 2000.

BRASIL. Ministério da Agricultura, Pecuária e Abastecimento. Cadeia produtiva de madeira. Ministério da Agricultura, Pecuária e Abastecimento, Secretaria de Política Agrícola, Instituto Interamericano de Cooperação para a Agricultura. coordenadores Antonio Márcio Buainain e Mário Otávio Batalha. Brasília : IICA : MAPA/ SPA, 2007. 84 p. (Agronegócios. v. 6) ISBN 978-85-99851-16-6

BRASIL. Ministério Do Meio Ambiente (MMA). Agenda 21 global. UNCED - Conferência das Nações Unidas sobre o Meio Ambiente e Desenvolvimento. 1992. Em português.

BRASIL. Ministério do Meio Ambiente (MMA). Agenda 21 Brasileira - Ações Prioritárias / Comissão de Políticas de Desenvolvimento Sustentável e da Agenda 21 Nacional. 2 ed. Brasília, 2004. 158p. Disponível em:

<http://www.mma.gov.br/responsabilidade-socioambiental/agenda-21/agenda-21-brasileira>. Acesso em 14 abr. 2015.

BRAZOLIN, S.; ROMAGNAMO, L. F.; SILVA, G. A. Madeira preservada no ambiente construído: cenário atual e tendências. In: ENCONTRO NACIONAL SOBRE EDIFICAÇÕES E COMUNIDADES SUSTENTÁVEIS, 3, 2003. São Carlos. Anais... São Carlos: ANTAC, 2003. CD-ROM. Seção artigos.

BURSZTYN, M.; MENDES, A.; SACHS, I.; BUARQUE, C.; DOWBOR, L.; AGUIAR, R.C.; BECKER, B.; LEITÃO, P. Para Pensar o Desenvolvimenlo Sustentável. IBAMA - Instituto Brasileiro de Meio Ambiente e Recursos Naturais Renováveis, ENAP - Fundação Escola Nacional de Administração Pública, Editora Brasiliense. 1994.

CALIL JUNIOR, C.; BRITO, L. D. Manual de projeto e construção de estruturas com peças roliças de madeira de reflorestamento. São Carlos: EESC/USP, 2010. ISBN 97885-8023-000-0.

CAMPOS, E. F.; PUNHAGUI, K. R. G.; JOHN, V. M. Emissão de $\mathrm{CO}_{2}$ do transporte da madeira nativa da Amazônia. Revista Ambiente Construído, Porto Alegre, RS, v. 11, n. 2, p. 157-172, abr./jun. 2011.

CAMPOS, E. F. Emissão de $\mathbf{C O}_{2}$ da madeira serrada da Amazônia: o caso da exploração convencional. 2012. Dissertação (mestrado em Engenharia) - Escola Politécnica, Universidade de São Paulo, São Paulo, 2012. 
CCA RESEARCH HOMEPAGE. Research on the environmental impacts of treated wood. How Chartherm Works?. Disponível em:

<http://www.ccaresearch.org/ccaconference/post/pdf/Hery_poster.pdf>. Acesso: 31 mar. 2016.

CÉSAR, S. F.; CUNHA R. D. A.; GUEDES J. P. L. Móveis de madeira reciclada: o design como ferramenta na produção de produtos mais sustentáveis. In: ENCONTRO BRASILEIRO EM MADEIRA E EM ESTRUTURAS DE MADEIRA, 7, 2010, Lavras. Anais... Lavras: IBRAMEM, 2010.

COMELATO, J. S.; VARASQUIM, F. M. F. A. Quantificação de resíduos sólidos dos laboratórios de serraria e celulose da Unesp de Itapeva. In: ENCONTRO BRASILEIRO EM MADEIRA E EM ESTRUTURAS DE MADEIRA, 12, 2012, Vitória. Anais... Vitória: IBRAMEM, 2012.

CORBELLA, O.; YANNAS, S. Em Busca de uma Arquitetura Sustentável para os Trópicos: conforto ambiental. 1.ed. Rio de Janeiro: Revan, 2003.

CRUZEIRO, E. C. Produção e construção de casas em madeira de reflorestamento sistema I.F. 1998. Dissertação (mestrado) - Escola de Engenharia de São Carlos, Universidade de São Paulo (EESC/USP), São Carlos, 1998.

CUNHA, R. D. A., CÉSAR, S. F. Arquitetura Sustentável em madeira de Pinus e Eucalipto. In: I CONFERÊNCIA LATINOAMERICANA DE CONSTRUÇÃO SUSTENTÁVEL E X ENCONTRO NACIONAL DE TECNOLOGIA DO AMBIENTE CONSTRUÍDO, 2004, São Paulo. Anais... São Paulo, 2004.

DEL CARPIO, J. C. Ensambles en madera, redescrubrimiento del ensamble tradicional: uma orientación en la construcción en América Latina. Lima: Cambium, 1990. Centro latinoamericano de promocionn y desarrollo de la madera. $110 \mathrm{p}$.

DORFLES, G., O Design Industrial e a sua Estética. Lisboa: Presença, 1991.

FERREIRA, O. P. (Coord.). Madeira: uso sustentável na construção civil. São Paulo: Instituto de Pesquisas Tecnológicas, 2003. SVMA: Sinduscon-SP (Publicação IPT; 2980).

FOOD AND AGRICULTURE ORGANIZATION OF THE UNITED NATIONS (FAO). GIobal forest resources assessment, FRA 2005: terms and definitions. Rome, 2004. $34 \mathrm{p}$. Disponível em: <http://www.fao.org/forestry/media/7797/1/0>. Acesso em: 30 ago. 2015.

FOOD AND AGRICULTURE ORGANIZATION OF THE UNITED NATIONS (FAO) - Statistics Division. FAOSTAT Domains, Forestry, 2016. Disponível em:

<http://faostat3.fao.org/browse/F/*/E>. Acesso: 31 mar. 2016. 
FORSTER, P.; RAMASWAMY, V.; ARTAXO, P.; BERNTSEN, T.; BETTS, R.; FAHEY, D. W.; HAYWOOD, J.; LEAN, J.; LOWE, D. C.; MYHRE, G.; NGANGA, J.; PRINN, R.; RAGA, G.; SCHULZ, M.; VAN DORLAND, R. Ch. 2: Changes in atmospheric constituents and in radiative forcing. Climate Change 2007: The Physical Science Basis. Contribution of Working Group I to the Fourth Assessment Report (AR4) of the Intergovernmental Panel on Climate Change. Editado por S. Solomon, D. Qin, M. Manning, Z. Chen, M. Marquis, K. B. Averyt, M. Tignor, and H. L. Miller. Cambridge University Press. 2007. Disponível em:

<https://www.ipcc.ch/publications_and_data/ar4/wg1/en/faq-2-1.html> Acesso em 28 Mar. 2016.

GARCIA, R. Cientistas finalizam relatório que reafirma culpa humana no aquecimento global, 22 set. 2013. [Online]. Disponivel em:

$<$ https://www.publico.pt/ecosfera/noticia/cientistas-finalizam-relatorio-que-reafirma-culpahumana-no-aquecimento-global-1606759>. Acesso em 28 Mar. 2016.

GAUZIN-MULLER, D. Arquitetura Ecológica. São Paulo: Editora Senac São Paulo, 2011. $304 \mathrm{p}$.

GERILLA, G. P.; TEKNOMO, K.; HOKAO, K. An environmental assessment of wood and steel reinforced concrete housing construction. Building and Environment, vol. 42, n. 7, p. 2778-2784, jul. 2007. Disponível em:

<http://www.sciencedirect.com/science/article/pii/S0360132306002010>. Acesso em: 28 Mar. 2016.

GESUALDO, F. A. R. Estruturas de madeira. Universidade Federal de Uberlândia, faculdade de Engenharia Civil (FECIV). 2003. 93p. Notas de aula. Disponível em: < http://www.feciv.ufu.br/sites/feciv.ufu.br/files/Anexos/Bookpage/Notas_de_Aula_Madeiras.pdf> Acesso em: 18 jul. 2013.

GONZAGA, A. L. Madeira: Uso e Conservação. Brasília, DF: IPHAN/MONUMENTA, 2006. 246p. (Cadernos Técnicos; 6).

GUIMARÃES, J.; VERÍSSIMO, A.; AMARAL, P.; DEMACHKI, A. Municípios Verdes: Caminhos para a Sustentabilidade. 2011. Belém, PA: IMAZON. 154p. Disponível em: $<$ http://www.imazon.org.br/publicacoes/livros/municipios-verdes-caminhos-para-asustentabilidade>. Acesso em: 18 jul. 2013

GUSTAVSSON, L.; PINGOUD, K.; SATHRE, R. Carbon Dioxide Balance of Wood Substitution: Comparing Concrete and Wood-Framed Buildings. Mitig Adapt Strat Glob Change, vol. 11, n. 3, p. 667-691, 2006.

GUSTAVSSON, L.; SATHRE, R. Variability in energy and carbon dioxide balances of wood and concrete building materials. Building and Environment, vol. 41, n. 7, p. 940-951, 2006. 
HELSEN, L. The Chartherm process, what's in the name? In: Waste Management 29, 1649-1657. 2008.

INSTITUTO BRASILEIRO DE GEOGRAFIA E ESTATÍSTICA (IBGE), Censo demográfico 2010. Disponível em: <http://www.sidra.ibge.gov.br/cd/cd2010rpu.asp?o=6\&i=P>. Acesso em: 28 mar. 2016.

INO, A.; SHIMBO, I. Habitação social em madeira de reflorestamento como alternativa econômica para usos múltiplos da floresta. São Carlos, 1999. Projeto de pesquisa (FAPESP), EESC/USP.

INO, A. Sistema Estrutural Modular em Eucalipto Roliço para Habitação. 1992. Tese (doutorado) - Escola Politécnica, Universidade de São Paulo, São Paulo. 212 p.

INTERNATIONAL COUNCIL FOR RESEARCH AND INNOVATION IN BUILDING AND CONSTRUCTION (CIB); UNITED NATIONS ENVIRONMENT PROGRAMME INTERNATIONAL ENVIRONMENTAL TECHNOLOGY CENTRE (UNEP-IETC). Agenda 21 for sustainable construction in developing countries: a discussion document. Prepared by: Chrisna du Plessis. South Africa, 2002. Disponível em:

< http://site.cibworld.nl/dl/publications/Agenda21Book.pdf>. Acesso em: 28 Mar. 2016.

INSTITUTO DE MANEJO E CERTIFICAÇÃO FLORESTAL E AGRÍCOLA (IMAFLORA). Relatório Anual de Atividades e de Resultados, 2011. 73 p. Disponível em <http://www.imaflora.org/downloads/biblioteca/50588d3fb87e6_relatrio_anual_2011.pdf>. Acesso em: 18 jul. 2013

INSTITUTO DE PESQUISAS TECNOLOGICAS (IPT) madeira: Uso sustentável na construção civil. Oswaldo Poffo Ferreira (Coord.). São Paulo: Instituto de Pesquisas Tecnológicas: SVMA: Sinduscon-SP, 2003.

INSTITUTO DO HOMEM E MEIO AMBIENTE DA AMAZÔNIA (IMAZON). Relatório de Atividades 2011. 58p. Disponível em: <http://www.imazon.org.br/publicacoes/relatorio-deatividades/relatorio-de-atividades-2011-1>. Acesso em: 18 jul. 2013

INTERGOVERNMENTAL PANEL ON CLIMATE CHANGE (IPCC), Revised 1996 IPCC Guidelines for National Greenhouse Gas Inventories, vol. Workbook. Module I. Energy, 3 vol, 1997. Disponível em:

<http://www.ipcc-nggip.iges.or.jp/public/gl/invs5.html>. Acesso em 28 mar. 2015.

INTERNATIONAL ORGANIZATION FOR STANDARDIZATION. ISO 21929: Sustainable in building construcion - Sustainability indicators - part1: Framework for the development of indicators and a core set of indicators for buildings, 2011.

JUNTA DEL ACUERDO DE CARTAGENA PADT-REFORT. Manual de diseño para maderas del grupo andino. 1 ed. Lima: JUNAC, 1984. 
KARL, T. R.; MELILLO, J. T.; PETERSON, T. C. Global Climate Change Impacts in the United States. Cambridge University Press, 2009. 189 p. Disponível em: $<$ http://downloads.globalchange.gov/usimpacts/pdfs/climate-impacts-report.pdf >. Acesso em 28 mar. 2016.

KEELER, M.; BURKE, B. Fundamentos de projeto de edificações sustentáveis. Tradução técnica: Alexandre Salvaterra. Porto Alegre: Bookman, 2010, 362p.

KRONKA R. C. Arquitetura, Sustentabilidade e Meio Ambiente. In: II ENCONTRO NACIONAL E I ENCONTRO LATINO AMERICANO SOBRE EDIFICAÇÕES E COMUNIDADES SUSTENTÁVEIS, 2001, Canela. Anais... Canela, 2001.

INSTITUTO DE MANEJO E CERTIFICAÇÃO FLORESTAL E AGRÍCOLA (IMAFLORA). Acertando o alvo 3. Marco W. Lentini, Patrícia, Cota Gomes, Leonardo Sobral (Coord.) Piracicaba, SP: Imaflora, 2012. 73 p. Disponível em:

<http://www.imaflora.org/downloads/biblioteca/ebook_acertando_o_alvo_3.pdf>. Acesso em: 14 abr. 2015.

MARTINS, T. F. R. M. Dimensionamento de Estruturas em Madeira - Coberturas e Pavimentos. 2010. Dissertação (mestrado) - Instituto Superior Técnico, Universidade Técnica de Lisboa, Lisboa, 2010.

MARTINS, H.; FONSECA, A.; SOUZA JR. C.; SALES, M.; VERÍSSIMO, A. 2013. Boletim Transparência Florestal da Amazônia Legal (Junho de 2013). 13p. Belém, PA: Imazon, 2014.

MATEUS, R. Avaliação da Sustentabilidade da Construção. 2009. Tese (Doutorado) Universidade do Minho, 2009.

MELILLO, J. M.; RICHMOND, T.; YOHE, G. W. Climate Change Impacts in the United States: The Third National Climate Assessment. U.S. Global Change Research Program, 2014. 841 p. Disponível em:

<http://s3.amazonaws.com/nca2014/high/NCA3_Climate_Change_Impacts_in_the_United\% 20States_HighRes.pdf?download=1 1 . Acesso em 26 mar. 2016.

MONTANA QUÍMICA. Destinação Final de Madeira Tratada com CCA. Informativo Técnico - Divisão Osmose, 2010.

MONTEIRO, A.; CONRADO, D.; CARDOSO, D.; VERÍSSIMO, A.; SOUZA Jr. C. Transparência Manejo Florestal do Estado do Pará (2009 e 2010). Imazon, 2011. 
MONTEIRO, J. H. P.; FIGUEIREDO, C. E. M.; MAGALHÃES, A. F.; MELO, M. A. F.; BRITO, J. C. X.; ALMEIDA, T. P. F.; MANSUR, G. L. Manual de Gerenciamento Integrado de resíduos sólidos. IBAM, 2001.

MORESCHI, J. C. Produtos preservantes de madeira. Universidade Federal do Paraná, Curso de Pós-graduação em Engenharia Florestal, 2005.

MORESCHI, J. C. Biodegradação e preservação da madeira, volume III, Métodos de tratamento da madeira. Universidade Federal do Paraná, Departamento de Engenharia e Tecnologia Florestal. 4 ed. 2013

NIEMEYER, L. Design no Brasil: Origens e Instalação. 3ª Ed. Rio de Janeiro: 2AB, 1997.

OLIVEIRA, J. T. S. Características da madeira de eucalipto para a construção civil. 1997. Tese (Doutorado) - Escola Politécnica, Universidade de São Paulo, São Paulo. 429p.

PEDROSA, A. L. Performance de vigas "I" constituídas por flanges de PLP e almas de compensado de Pinus taeda L. e Eucalipto dunnii Maiden e alma de OSB de Pinus spp., 2003. Dissertação (mestrado) - Universidade Federal do Paraná, Curitiba, 2003.

PEREIRA, D.; SANTOS, D.; VEDOVETO, M.; GUIMARÃES, J.; VERÍSSIMO, A. Fatos florestais da Amazônia - 2010. Belém, PA: Imazon, 2010.

PFEIL, W.; PFEIL, M. Estruturas de Madeira. 6 ed. Rio de Janeiro: Livros Técnicos e Científicos, 2003.

PINHEIRO, M. D. Ambiente e Construção Sustentável. Instituto do Ambiente. 2006. Disponível em: <http://www.lidera.info/resources/ACS_Manuel_Pinheiro.pdf>. Acesso em: 14 abr. 2015.

PUNHAGUI, K. R. G. Potencial de reducción de las emisiones de $\mathrm{CO}_{2}$ y de la energia incorporada en la construcción de viviendas en Brasil mediante el incremento del uso de la madera. 2014. Tese (Doutorado) - Universidad Politécnica de Cataluña y Universidade de São Paulo. Barcelona, 2014.

RAMOS, I. E. C.; PAES, J. B.; SOBRINHO, D. W. F.; SANTOS, G. J. C. Eficiência Do CCB na Resistência da Madeira de Algaroba (Prosopis Juliflora (Sw.) D.C.) em Ensaio de Apodrecimento Acelerado. Revista da Árvore, Viçosa, MG, v.30, n. 5, p.811-820, 2006.

REIS, D. C. Ferramenta de apoio ao desenvolvimento de projeto no âmbito da sustentabilidade na construção. 2015. Dissertação (Mestrado em Arquitetura e Urbanismo) - Instituto de Arquitetura e Urbanismo da Universidade de São Paulo, São Carlos. 2015. 
REKOLA, M.; MÄKELÄINEN, T.; HÄKKINEN, T. The role of design management in the sustainable building process. Architectural Engineering and Design Management. Finland, p. 78-89, 2012. Disponível em:

$<$ https://www.researchgate.net/publication/254216923_The_role_of_design_management_in _the_sustainable_building_process>. Acesso em: 26 mar. 2016.

RIBEIRO, P. T. Fomento da produção de carvão vegetal de floresta plantada na microrregião de Capelinha e a sua influência no desenvolvimento sócio-econômico da região. 2013. Dissertação (Mestrado em Gestão Integrada do Território) - Universidade Vale do Rio Doce, Governador Valadares, 2013.

ROMÉRO, M. A.; BRUNA, G. C. Metrópole e o desafio urbano frente ao meio ambiente. Série Sustentabilidade, v.6. José Goldemberg (Coord.). São Paulo: Blucher, 2010. ISBN 978-85-212-0574-6

ROODMAN, D. M.; LENSSEN, N. A building revolution: how ecology and health concerns are transforming construction. Worldwatch Paper, 124, 1995. 67 p. Disponível em:

<http://www.worldwatch.org/node/866>. Acesso em: 28 mar. 2016.

SANTOS, D.; PEREIRA, D.; VERÍSSIMO, A. O estado da Amazônia: uso da terra, Imazon, Instituto do Homem e Meio Ambiente da Amazônia, Belém, 2013.

SATHRE R.; GUSTAVSSON, L. Using wood products to mitigate climate change: External costs and structural change, Applied Energy, vol. 86, n. 2, p. 251-256, 2009.

SATHRE, R.; O'CONNOR, J. Meta-analysis of greenhouse gas displacement factors of wood product substitution, Environmental Science \& Policy, vol. 13, n. 2, p. 104-114, 2010.

SERVIÇO FLORESTAL BRASILEIRO (SFB). Florestas do Brasil em resumo - 2010: dados de 2005-2010. Brasília: SFB, 2010.152 p.

SERVIÇO FLORESTAL BRASILEIRO (SFB); INSTITUTO DO HOMEM E MEIO AMBIENTE DA AMAZÔNIA (IMAZON). A atividade madeireira na Amazônia brasileira: produção, receita e mercados, Belém, 2010.

SERVIÇO FLORESTAL BRASILEIRO (SFB). Florestas do Brasil em resumo - 2013: dados de 2007-2012. Brasília: SFB, 2013. 188 p. Disponível em:

<http://www.florestal.gov.br/publicacoes/tecnico-cientifico/florestas-do-brasil-em-resumo2013>. Acesso em: 15 jul. 2013.

SILVA, S. R. M.; SHIMBO, I. Proposição Básica para Principios de Sustentabilidade. In: II ENCONTRO NACIONAL E I ENCONTRO LATINO AMERICANO SOBRE EDIFICAÇÕES E COMUNIDADES SUSTENTÁVEIS, 2001, Canela. Anais... Canela, 2001. 
SILVA, H. M.; ANDRADE, C. S. R. Produção mais limpa e desenvolvimento sustentável: um estudo de caso no setor moveleiro. In: ENCONTRO BRASILEIRO EM MADEIRA E EM ESTRUTURAS DE MADEIRA, 12, 2010, Lavras. Anais... Lavras: IBRAMEM, 2010.

SILVA, V. G. Avaliação da sustentabilidade de edifícios de escritórios brasileiros: diretrizes e bases metodológicas. 2003. PhD Tese - Universidade de São Paulo, São Paulo, 2003.

SISTEMA DE INFORMAÇÕES FLORESTAIS DO ESTADO DE SÃO PAULO (SISFLOR). Disponível em: <www.sisflor.org.br>. Acesso em 30 ago. 2015.

SISTEMA NACIONAL DE INFORMAÇÕES FLORESTAIS (SNIF). Disponível em: $<$ http://www.florestal.gov.br/snif/>. Acesso em 30 ago. 2015.

SOARES, S. R.; SOUZA, D. M; e PEREIRA S. W. A avaliação do ciclo de vida no contexto da construção civil In: SATTLER, M. A.; PEREIRA, F. O. R. (Ed.). Construção e Meio Ambiente. Porto Alegre: Associação Nacional de Tecnologia do Ambiente Construído (ANTAC), 2006. (Coleção Habitare, v. 7). 296 p. Disponível em:

<http://www.habitare.org.br/publicacoes_coletanea7.aspx>. Acesso em: 31 mar. 2016.

TAVARES, S. F. Metodologia de análise do ciclo de vida energético de edificações residenciais brasileiras. Universidade Federal de Santa Catarina, 2006.

TEIXEIRA, M. G.; CÉSAR, S. F. Resíduo de madeira como possibilidade sustentável para produção de novos produtos. In: I CONFERÊNCIA LATINOAMERICANA DE CONSTRUÇÃO SUSTENTÁVEL - X ENCONTRO NACIONAL DE TECNOLOGIA DO AMBIENTE CONSTRUÍDO, 2004, São Paulo. Anais... São Paulo: ANTAC, 2004.

TORGAL, F. P.; JALALI, S. A Sustentabilidade dos Materiais de Construção. Guimarães: Tec. Minho. 2010. v. I

UNITED NATIONS ENVIRONMENT PROGRAMME (UNEP); SUSTAINABLE BUILDINGS \& CLIMATE INITIATIVE (SBCI). Why Buildings. Disponível em:

<http://www.unep.org/sbci/AboutSBCl/Background.asp>. Acesso em: 31-mar-2016.

UNITED NATIONS FRAMEWORK CONVENTION ON CLIMATE CHANGE (UNFCCC), Kyoto Protocol. Disponível em: <https://unfccc.int/kyoto_protocol/items/2830.php>. Acesso em: 26 mar. 2016.

VALLE, I. M. R.; INO, A.; FOLZ R. R.; CALIL JR, C. A Pré-Fabricação na Construção em Madeira no Brasil. In: ENCONTRO BRASILEIRO EM MADEIRA E EM ESTRUTURAS DE MADEIRA, 12, 2012, Vitória. Anais... Vitória: IBRAMEM, 2012. 
XIMENES, F. A.; GRANT, T. Quantifying the greenhouse benefits of the use of wood products in two popular house designs in Sydney, Australia. Int J Life Cycle Assess, vol. 18 , n. 4, p. 891-908, 2013.

YUBA, A. N.; INO A.; SHIMBO, I. Proposição de etapas gerais para análise de sustentabilidade da cadeia produtiva da habitação em madeira. In: ENCONTRO NACIONAL SOBRE EDIFICAÇÕES E COMUNIDADES SUSTENTÁVEIS, 3, 2003, São Carlos. Anais... São Carlos: ANTAC, 2003. CD-ROM. Seção artigos.

ZENID, G. J. (Coord.). Madeira: uso sustentável na construção civil. 2 ed. São Paulo: Instituto de Pesquisas Tecnológicas, SVMA, 2009. (Publicação IPT; 3010). 


\section{ANEXO A - FICHA TÉCNICA DO EUCALYPTUS CITRIODORA}

\section{EUCALIPTO-CITRIODORA - Eucalyptus citriodora Hook., Myrtaceae.}

\section{OUTROS NOMES POPULARES}

eucalipto

\section{OCORRÊNCIA}

Brasil: Minas Gerais, São Paulo, Bahia, Maranhão, Pernambuco, Paraíba.

Outros países: Austrália, Portugal, África do Sul, Zimbábue, Ruanda, Tanzânia,

Malawi, Quênia, Tailândia, Indonésia, China.

\section{CARACTERÍSTICAS GERAIS}

Características sensoriais: cerne e alburno distintos pela cor, cerne pardo, alburno branco-amarelado; sem brilho; cheiro e gosto imperceptíveis; densidade alta; dura ao corte; grã variável: direita, ondulada e revessa; textura fina a média.

Descriçăo anatômica macroscópica: parênquima axial: visível apenas sob lente, paratraqueal vasicêntrico e aliforme de aletas curtas. Raios: visíveis apenas sob lente no topo e na face tangencial; finos; de poucos a numerosos. Vasos: visíveis a olho nu, pequenos a médios; poucos; porosidade difusa; arranjo radial e diagonal; solitários e múltiplos; obstruídos por tilos. Camadas de crescimento: pouco distintas, quando presente individualizadas por zonas fibrosas tangenciais mais escuras. $\underline{\text { Canais axiais }}$ traumáticos: presentes em alguns espécimes.

\section{DURABILIDADE NATURAL E TRATABILIDADE QUÍMICA}

Madeira suscetível à ação de xilófagos marinhos. Resistente ao apodrecimento. As informacōes sobre resistência ao ataque de cupins são contraditórias. 0 cerne é difícil de ser tratado, entretanto, o alburno é permeável.

\section{CARACTERISTICAS DE PROCESSAMENTO}

Trabalhabilidade: Madeira excelente para serraria, no entanto, requer 0 uso de técnicas apropriadas de desdobro para minimizar os efeitos das tensões de crescimento. Apresenta boas características de aplainamento, lixamento, furação e acabamento. Secagem: Em geral, as madeiras de espécies de eucalipto são consideradas como difíceis de secar, podendo ocorrer defeitos como colapso, empenamentos e rachas. A secagem em estufa deve ser feita de acordo com programas suaves, combinando, por exemplo, baixas temperaturas com altas umidades relativas. É recomendável a secagem ao ar, ou o uso de pré-secador, antes da secagem em estufa.

\section{PROPRIEDADES FISICAS*}

Densidade de massa $(\rho)$ :

aparente a $15 \%$ de umidade $\left(\rho_{\mathrm{ap} .15}\right): 1040 \mathrm{~kg} / \mathrm{m}^{3} /$ básica $\left(\rho_{\text {basicas }}\right): 867 \mathrm{~kg} / \mathrm{m}^{3}$

Contração: radial: $6,6 \%$ / tangencial: 9,5\% / volumétrica: $19,4 \%$

PROPRIEDADES MECÂNICAS*

Flexão

Resistência - $f$

Madeira verde (MPa): 111,8

Madeira a $15 \%$ de umidade (MPa): 121,4

Limite de Proporcionalidade - madeira verde (MPa): 47,2

Módulo de Elasticidade - madeira verde (MPa): 13337

Compressão paralela às fibras ou

Resistência $-f_{c 0}$

Madeira verde (MPa): 51,1

Madeira a $15 \%$ de umidade (MPa): 62,8

Limite de Proporcionalidade - madeira verde (MPa): 33,7

Módulo de Elasticidade - madeira verde (MPa): 15867

Coeficiente de influência de umidade (\%): 4.7

OUTRAS PROPRIEDADES MECÄNICAS*

Resistência ao impacto na Flexäo - madeira a 15\% (choque) - Trabalho Absorvido (J): 45,3 Cisalhamento - madeira verde (MPa): 16,3

Dureza Janka paralela - madeira verde (N): 8757

Tração Normal às Fibras - madeira verde (MPa): 10,1

Fendilhamento - madeira verde (MPa): 1,2

USOS NA CONSTRUÇÃO CIVIL

Pesada externa: postes, cruzetas, dormentes, mourões.

Pesada interna: vigas e caibros.

OUTROS USOS

Móveis estândar, cabos de ferramentas, embarcações.

OBSERVAGÖES

Madeira de reflorestamento.

Os eucaliptos representam um grupo muito variado de madeiras, com densidades desde

$500 \mathrm{~kg} / \mathrm{m}^{3}$ até $1000 \mathrm{~kg} / \mathrm{m}^{3}$. A espécie de Eucalyptus citriodora é adequada ao uso em

peças estruturais pelas suas características de resistência mecânica, durabilidade natural

e menor tendência ao rachamento.

*) Resultados obtidos de acordo com a Norma ABNT MB26/53 (NRR 6230/85) Fonte. IPT, 1989

Fonte: IPT (2003) 


\section{ANEXO B - FICHA TÉCNICA DO EUCALYPTUS GRANDIS}

\section{EUCALIPTO-GRANDIS - Eucalyptus grandis W. Hill ex Maiden., Myrtaceae.}

\section{OUTROS NOMES POPULARES}

eucalipto

\section{OCORRÊNCIA}

Brasil: Espirito Santo, Minas Gerais, São Paulo, Goiás, Mato Grosso, Paraná, Rio Grande do Sul, Bahia.

Outros paises: Zimbábue, Nigéria, Malawi, África do Sul, Quênia, Congo, Zaire, Nova Zelândia.

\section{CARACTERÍSTICAS GERAIS}

Características sensoriais: cerne e alburno distintos pela cor, cerne castanhorosado-claro, alburno bege-rosado; pouco brilho; cheiro e gosto imperceptíveis; densidade baixa; macia ao corte; grã direita; textura fina a média.

Descrição anatômica macroscópica: parênquima axial: indistinto mesmo sob lente. paratraqueal vasicêntrico escasso. Raios: visíveis apenas sob lente no topo, finos. Vasos: visiveis a olho nu, pequenos a médios; poucos; porosidade difusa; arranjo

diagonal; solitários; obstruídos por tilos. Camadas de crescimento: distintas, individualizadas por zonas fibrosas tangenciais mais escuras.

\section{DURABILIDADE NATURAL E TRATABILIDADE QUÍMICA}

Madeira considerada com moderada durabilidade aos fungos apodrecedores e cupins, e com baixa durabilidade aos fungos de podridão mole e cupins-de-solo

(Nasutitermes sp.). 0 cerne é difícil de ser tratado, entretanto, 0 alburno é permeável.

\section{CARACTERISTIICAS DE PROCESSAMENTO}

Trabalhabilidade: Madeira excelente para serraria, no entanto, requer 0 uso de técnicas apropriadas de desdobro para minimizar os efeitos das tensöes de crescimento. Apresenta boas características de aplainamento, lixamento, torneamento, furação e acabamento.

Secagem: Em geral, as madeiras de espécies de eucalipto são consideradas como difíceis de secar, podendo ocorrer defeitos como colapso, empenamentos e rachas. A secagem em estufa deve ser feita de acordo com programas suaves, combinando, por exemplo, baixas temperaturas com altas umidades relativas. É recomendável a secagem ao ar, ou 0 uso de pré-secador, antes da secagem em estufa. Programa de secagem pode ser obtido em Silva (2001).

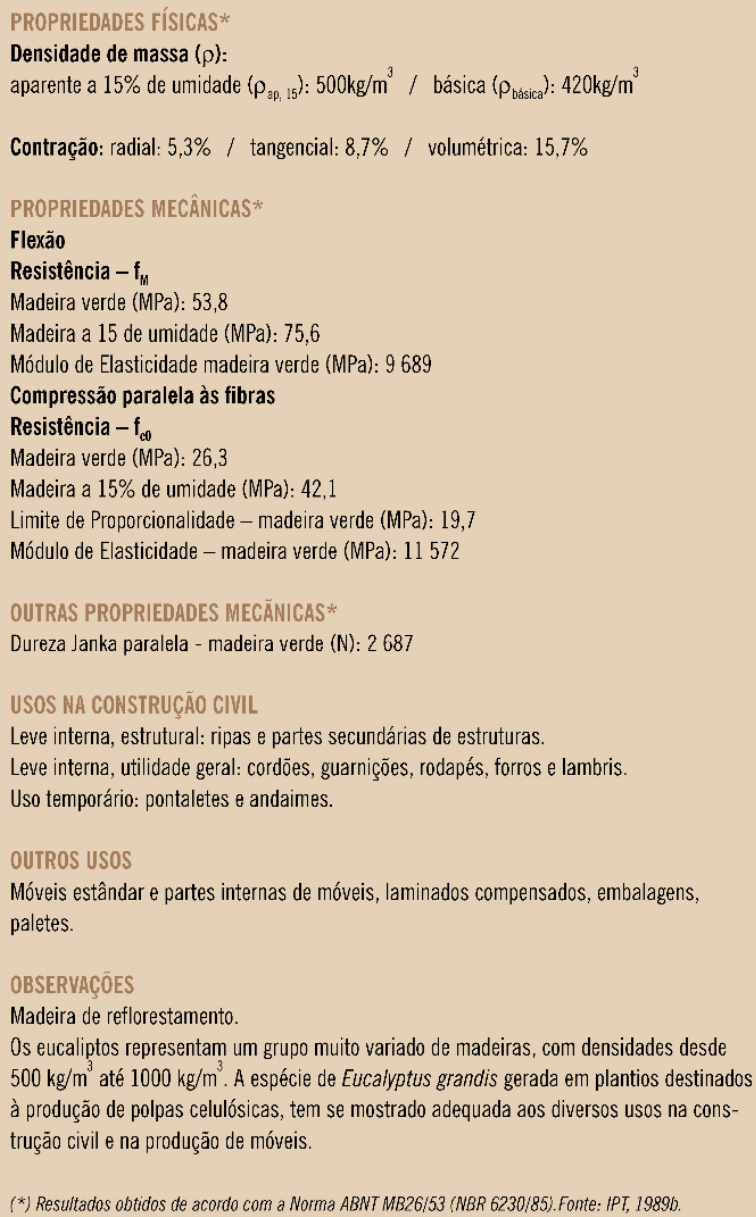

(*) Resultados obtidos de acordo com a Norma ABNT MB26/53 (NBR 6230/85). Fonte: IPT, 19890.

Fonte: IPT (2003) 


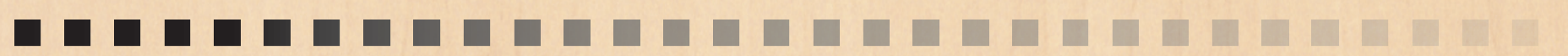

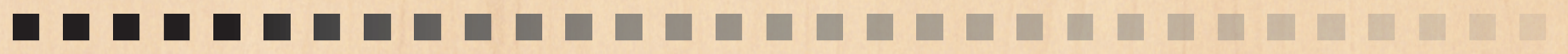

